UNIVERSIDADE DE SÃO PAULO

INSTITUTO DE GEOCIÊNCIAS

\title{
EVIDÊNCIAS TECTÔNICAS NO LESTE DA ILHA DO MARAJÓ: INTEGRAÇÃO DE DADOS MORFOESTRUTURAIS E GEOFÍSICOS
}

\author{
LENA SIMONE BARATA SOUZA \\ Orientadora: Profa. Dra. Dilce de Fátima Rossetti \\ Co-orientador: Prof. Dr. Renato Luiz Prado
}

TESE DE DOUTORAMENTO

Programa de Pós-Graduação em Geoquímica e Geotectônica

SÃO PAULO

2010 
Dedico

Aos meus pais (Agenor \& Maria) 


\section{AGRADECIMENTOS}

À Universidade de São Paulo/Instituto de Geociências (USP/IGc), pela logística e infraestrutura cedidas para execução deste trabalho.

À Fundação de Amparo à Pesquisa do Estado de São Paulo (FAPESP), bolsa de estudo.

Ao Instituto Nacional de Pesquisas Espaciais (INPE), pela infraestrutura cedida para conclusão deste trabalho.

A Prof. Dra. Dilce de Fátima Rossetti (INPE), orientadora, pela paciência, incentivo e dedicação durante as etapas de desenvolvimento desta tese.

Ao Prof. Dr. Renato Luiz Prado (IAG/USP), co-orientador, por sempre se mostrar disponível a exaurir as minhas dúvidas sobre geofísica.

Ao Prof. Dr. Vagner Roberto Elis (IAG/USP), que acompanhou de forma sempre solícita o processamento e interpretação dos dados de sondagem elétrica vertical (SEV).

À Prof. Dra. Ana Maria Góes (IGc/USP), pelo incentivo, preocupação e por todas suas palavras doces que me acompanharam até o final desta tese.

Ao Prof. Dr. José Gouvêa Luiz/UFPA, por disponibilizar o equipamento de geofísica GEOTEST RD-300A, para coleta de dados de SEV na ilha do Marajó/PA.

Ao Museu Paraense Emílio Goeldi (MPEG), pela liberação do equipamento GPR SYR-2 para coleta de dados radar na ilha do Marajó. E aos seus funcionários, Stélio e Roseno, pela preciosa ajuda nas etapas de campo na ilha. Menciono ainda, Odilon, residente da ilha, que também muito contribuiu nestas etapas.

Aos funcionários do IGc/USP, Ana Paula Cabanal e Tadeu Caggiano, pela disposição dada a mim.

Aos colegas de curso da pós, Evelyn, por dividir momentos bons e ruins, principalmente nas etapas iniciais deste trabalho, e Clódis, pelo auxílio e aprendizado no uso de programas computacionais (p.e., Spring, ArcGis e Global Mapper).

Aos meus pais (Maria \& Agenor) que fizeram do seu amor e dedicação o pilar da pessoa que sou hoje.

Aos meus irmãos (Leny, Leno, Leda, Leisa e Larissa) e sobrinho (Pedro), que fizeram do seu amor meu "porto seguro". 
À Jackson Paz, por estar presente nesta minha longa jornada.

À família Torres, que me acolheu com muito carinho ao longo desses 4 anos de doutorado e estadia na cidade de São Paulo. Em especial, a D. Minervina e a Simei, quero expressar o quanto serei eternamente grata.

Aos amigos distantes, Grace, Eisner e Emídio, por emanarem vibrações positivas. E a amiga aqui de perto, Maria Pinheiro "Mary", a quem posso chamar de irmã.

A todos aqueles que de alguma forma contribuíram para a execução deste trabalho. 
Trecho da música: "Esperando por mim".

Digam o que disserem Meu pai sempre esteve esperando por mim.

Digam o que disserem Minha mãe sempre esteve esperando por mim.

Digam o que disserem Agora meu filho espera por mim.

Digam o que disserem Meus verdadeiros amigos sempre esperaram por mim.

(Legião Urbana). 


\section{SUMÁRIO}

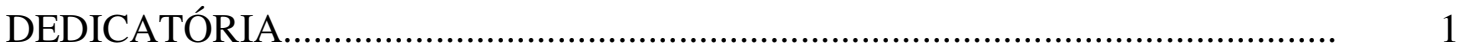

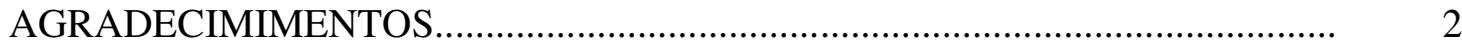

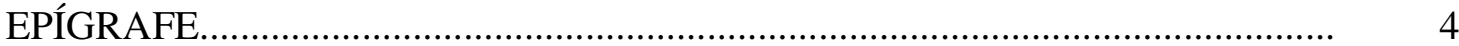

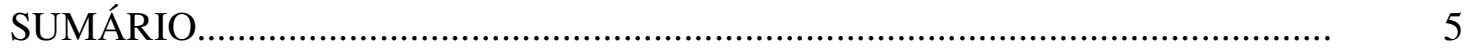

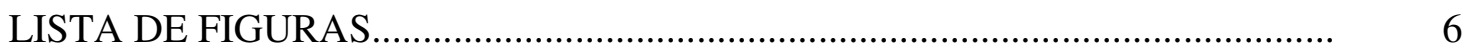

LISTA DE TABELAS........................................................................... 10

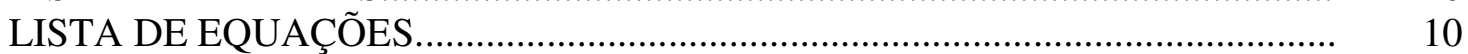

LISTA DE ANEXOS............................................................................ 10

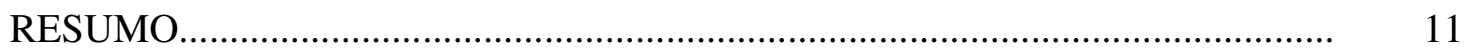

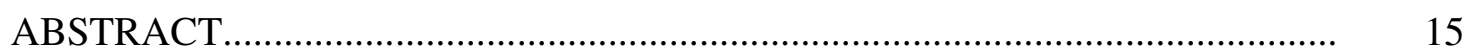

1. INTRODUÇÃO

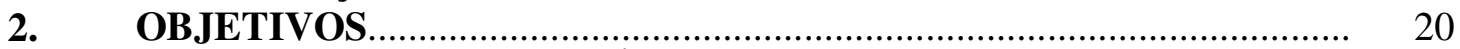

3. CARACTERIZAÇÃO DA ÁREA DE ESTUDO...................................... 21

3.1. Generalidades e Vias de Acesso ……………………………………….... 21

3.2. Aspectos Fisiográficos.......................................................................... 23

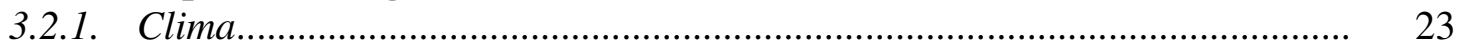

3.2.2. Solo

3.2.3. Topografia.................................................................................... 24

3.2.4. Vegetação

3.2.5. Hidrografia ................................................................................. 26

4. CONTEXTO GEOLÓGICO_.................................................................. 27

5. FUNDAMENTAÇÃO TEÓRICA.......................................................... 32

5.1. Análise de Bacias de Drenagem............................................................. 33

5.2. Lineamento morfoestrutural e Sensoriamento Remoto (SR)................. 41

5.3. Radar de Penetração no Solo..................................................................... 43

5.4. Sondagem Elétrica Vertical.................................................................... 46

6. LEVANTAMENTOS GEOFÍSICOS NA ILHA DO MARAJÓ............. 50

7. METODOLOGIA ……………………………………………………..... 56

7.1. Sensoriamento Remoto (SR)................................................................. 56

7.2. Radar de Penetração no Solo (GPR) ..................................................... 57

7.3. Sondagem Elétrica Vertical (SEV) ......................................................... 60

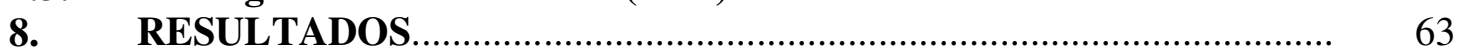

8.1. Caracterização das Bacias de Drenagem.................................................. 64

8.1.1. Bacia de drenagem do rio Arari (BDRA)...................................................... 66

8.1.2. Bacia de drenagem do rio Camará $(B D R C)$.............................................. 69

8.1.3. Bacia de drenagem do rio Paracauari (BDRP) _...........................................

8.1.4. Lineamentos Morfoestruturais................................................................ $\quad 75$

8.1.5. Fator de assimetria.............................................................................

8.1.6. Paleocanais.................................................................................. 79

8.2. Sondagem elétrica vertical (SEV) .......................................................... 80

8.2.1. Aspectos geológicos relevantes à interpretação dos dados geoelétricos.... $\quad 81$

8.2.2. Descrição dos dados geoelétricos............................................................... $\quad 84$ 
8.2.3. Descrição integrada de seções geoelétricas, dados geológicos e geomofológicos................................................................................ 90

8.3. Radar de penetração no solo.................................................................. 99

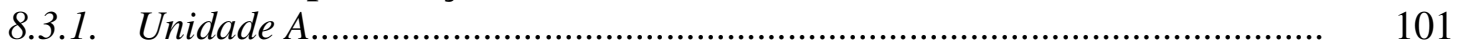

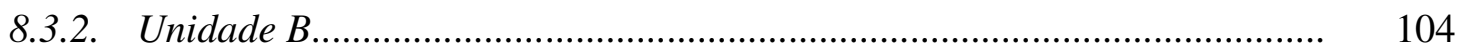

9. DISCUSSÃO .................................................................................... 129

9.1. Evidências tectônicas derivadas da análise de drenagem e da paleodrenagem................................................................................. 129

9.2. Evidências tectônicas derivadas da integração de dados geoelétricos, geológicos e morfoestruturais.............................................................. 133

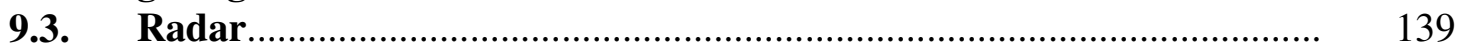

9.4. Mecanismo gerador de estruturas tectônicas na ilha do Marajó........... 145

9.4.1. Hipótese de associação com a tectônica andina......................................... 145

9.4.2. Hipótese associação com tectônica gravitacional....................................... 147

9.4.3. Hipótese de associação com rifteamento marginal................................... 149

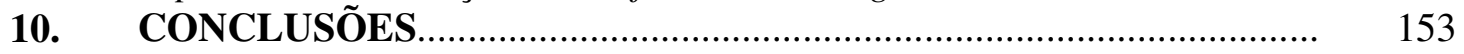

REFERÊNCIAS BIBLIOGRÁRICAS................................................... 157

\section{LISTA DE FIGURAS}

Figura 1 - Mapa de localização da área de estudo na porção leste ilha do Marajó...........................................................................................

Figura 2 - Mapa geológico do baixo rio Tocantins-ilha do Marajó (modificada de Rossetti \& Toledo, 2006).............................................................

Figura 3 - Coluna estratigráfica do Sistema de Graben do Marajó (modificada de Rossetti \& Valeriano, 2007)............................................................

Figura 4 - Principais propriedades de drenagem. (modificada de Soares \& Fiori, 1976).........................................................................

Figura 5 - Tipos de padrões de drenagem. (modificada de Howard,

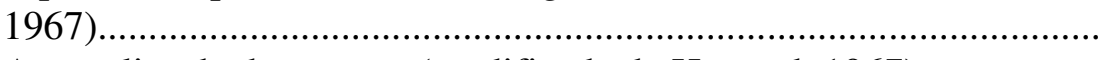

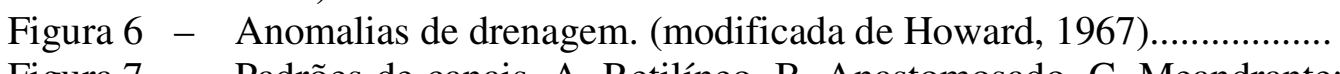

Figura 7 - Padrões de canais. A. Retilíneo. B. Anastomosado. C. Meandrante: (L) comprimento do meandro e $(\mathrm{Rc})$ raio médio da curvatura do meando. (modificada de Cunha, 1994).

Figura 8 - Quadro ilustrativo da aquisição de dados de GPR e perfil resultante. (A) Levantamento para aquisição de dados de GPR, mostrando os componentes do sistema e a configuração do refletor de subsuperfície. (B) Perfil de reflexão resultante e seus eventos Sísmicos.................................................................................

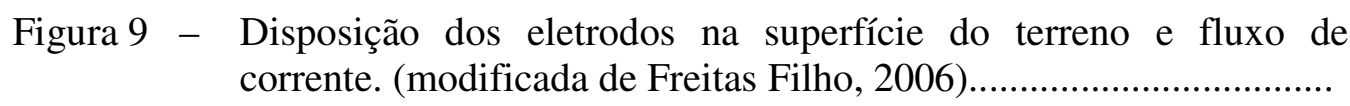

Figura 10 - Quadripolo AMNB (dispositivo Schlumberger). (modificada de Souza, 2005). 
Figura 11 - Sondagem Elétrica Vertical Tipo da ilha do Marajó. (modificada de IDESP, 1986).....

Figura 12 - Mapas de resistividades na porção oriental da ilha do Marajó. (A) linha $A B=2 \mathrm{~m}$. (B) linha $\mathrm{AB}=40 \mathrm{~m}$. (C) linha $\mathrm{AB}=300 \mathrm{~m}$. (D) linha $A B=400 \mathrm{~m}$ de profundidade. (modificada de Trancredi, 1972; IDESP, 1986).

Figura 13 - Perfis de resistividades em linhas AB de 2 m, 40 m, $200 \mathrm{~m}$ e $400 \mathrm{~m}$ de profundidade da parte oriental da ilha do Marajó. (A) N-S. (B) W-E. Estes perfis estão posicionados na Figura 12A. (modificada de Tancredi, 1972; IDESP, 1986)

Figura 14 - Seções geoelétricas. (A) Paleocanal Guajará Mirim. (B) Linha de Praia - São Miguel. (modificada de Porsani, 1981).

Figura 15 - Fotos ilustrando o equipamento de GPR utilizado na área pesquisada.

Figura 16 - Terminologia utilizada na descrição de superfícies estratigráficas e caracterização de estratos sedimentares em seções de GPR. (modificada de Neal, 2004).

Figura 17 - Fotos ilustrando o equipamento de SEV utilizado na área de estudo.

Figura 18 - Mapa das bacias de drenagem estudadas no leste da ilha do Marajó, derivado da combinação de dados digitais do IBGE/SIVAM com imagem Landsat.....

Figura 19 - Mapa de densidade de drenagem.

Figura 20 - Bacia de drenagem do rio Arari, com os principais padrões de drenagem. As letras A, B, C indicam anomalias de drenagem ilustradas na figura 21

Figura 21 - Imagem Landsat das anomalias de drenagem na BDRA (ver localização na figura 20). A. Mudanças rápidas no curso do rio Arari, com inflexões de $90^{\circ}$ (seta). B e C. Lagos formados a partir do abandono de canais (L). D e E. Meandro comprimido (círculos)

Figura 22 - Bacia de drenagem do rio Camará (ver legenda na figura 20). A e B indicam anomalias de drenagem ilustradas na figura 23.

Figura 23 - Imagem Landsat das anomalias de drenagem na BDRC (ver localização na figura 22). A. Lagos formados a partir do alargamento súbito de canais (L). B. Setor do rio Camará com variação de trechos retilíneos para meandros comprimidos (círculo). Observar, também, grupo de lagos alongados (delimitados por linhas contínuas) que estão em continuidade lateral com paleocanais (linhas pontilhadas).

Figura 24 - Bacia de drenagem do rio Paracauari (ver legenda na figura 21). A e B localizam as anomalias de drenagem ilustradas na figura 25 .

Figura 25 - Imagem Landsat das anomalias de drenagem na BDRP (ver localização na figura 24). A. Canais meandrantes (círculo) que mudam para retilíneos (quadrado). B. Lagos alongados devido ao rápido alargamento de canais $(\mathrm{L})$. 
Figura 26 - Lineamentos morfoestruturais derivados da análise da rede de drenagem atual

Figura 27 - Diagramas em roseta dos lineamentos morfoestruturais. A. Frequência absoluta ilustrando modas principais para NW e NE. B. Comprimento absoluto ilustrando modas principais para NW e NE. Notar que estas orientações são coincidentes com as obtidas para frequência absoluta, mostradas no diagrama em roseta da figura 27A.

Figura 28 - Mapa de densidade de lineamentos tectônicos. As letras I e II indicam compartimentos morfotectônicos

Figura 29 - Mapa de paleocanais derivados da análise visual de imagem Landsat. Círculos indicam locais onde ocorrem rápidos desvios de direção dos paleocanais, configurando ângulos retos. Setas indicam meandros isolados e comprimidos.

Figura 30 - Exposições da Formação Barreiras em uma falésia costeira na cidade de Salvaterra (A-D, onde SEV 1 a 4 foi adquirida), em um corte de estrada (E, G) e em uma trincheira na porção sudeste dessa cidade (F) (martelo $=35 \mathrm{~cm}$ de comprimento).

Figura 31 - Perfis litoestratigráficos na ilha do Marajó, com interpretação do arcabouço estratigráfico da sedimentação quaternária tardia (segundo Rossetti, 2010 no prelo).

Figura 32 - Mapa com a localização das sondagens elétricas verticais e das seções geológicas mostradas nas figuras 35, 37 e 38 . Notar, ainda, a localização dos poços P1 a P8 e da figura 36.

Figura 33 - Mapas de Isópaca (A) e tridimensional (B) baseados nos valores de resistividades (coordenadas em UTM).

Figura 34 - A-D) Tipos de curvas de resistividade derivadas das sondagens elétricas verticais.

Figura 35 - Seção geoelétrica A-A', interpretada a partir da integração de dados SEV com testemunhos de sondagem (ver localização na figura 32).

Figura 36 - Imagens Landasat (ver figura 32 para localização) ilustrando os lineamentos morfoestruturais que coincidem com as falhas (setas amarelas) mostradas nas seções A-A' (A), B-B' (B) e C-C' (A) ilustrada nas figuras 35,37 e 38 , respectivamente. Notar que vários outros lineamentos retilíneos que se interceptam mutuamente em ângulos retos (setas brancas). Os retângulos em A situam a área com a falha mostrada na seção A-A', e o paleocanal do Quaternário Superior-Holoceno descritos em associação com a seção C-C', respectivamente. Círculos nessa figura indicam áreas de lagos limitado abruptamente. Os retângulos em B indicam onde o rio Paracauari mostra várias inflexões para $90^{\circ} \mathrm{em}$ seu curso. Ver texto para maiores explicações (vermelho=floresta; verde amarelado ou azul=campo; preto=água; números=perfis de SEV).

Figura 37 - Seção geoelétrica interpretada a partir de SEV integradas com dados de testemunhos de sondagem ao longo do transecto B-B' (ver figura 32 para localização e figura 35 para legenda). Falhas 
indicadas nesta seção coincidem com um lineamento morfoestrutural marcado pelo curso de um rio mostrado na imagem Landsat observada na figura 36B.

Figura 38 - Seção geoelétrica interpretada a partir de sondagens elétricas verticais integradas a dados de testemunhos de sondagem ao longo do transecto C-C' (ver figura 32 para localização e figura 35 para legenda). As falhas indicadas nesta seção coincidem com o lineamento morfoestrutural marcado pelo curso de um rio mostrado na imagem Landsat observado na figura 36A.

Figura 39 - Mapa de localização dos dados de GPR................................................

Figura 40 - Seção de radar 1 na área urbana da cidade de Salvaterra (ver localização na figura 39). Notar que as letras A e C mostram a imagem de radar processada, $\mathrm{e}$ as $\mathrm{B}$ e $\mathrm{D}$ indicam a interpretação...

Figura 41 - Seção de radar 2 (ver localização na figura 39 e legenda na figura 40). Notar que as letras A, C e E mostram a imagem de radar processada, e as B, D e F indicam a interpretação.

Figura 42 - Seção de radar 3 (ver localização na figura 39 e legenda na figura 40). Notar que as letras A e C mostram a imagem de radar processada, e as B e D indicam a interpretação.

Figura 43 - Seção de radar 4 (ver localização na figura 39 e legenda na figura 40). Notar que as letras A e C mostram a imagem de radar processada, e as B e D indicam a interpretação.

Figura 44 - Seção de radar 5 (ver localização na figura 39 e legenda na figura 40). Notar que as letras A e C mostram a imagem de radar processada, e as B e D indicam a interpretação.

Figura 45 - Seção de radar 6 (ver localização na figura 39 e legenda na figura 40).

Figura 46 - Seção de radar 7 (ver localização na figura 39 e legenda na figura 40). Notar que a letra A mostra a imagem de radar processada, e a B indica a interpretação.

Figura 47 - Seção de radar 8 (ver localização na figura 39 e legenda na figura 40). Notar que a letras A mostra a imagem de radar processada, e a B indica a interpretação...

Figura 48 - Seção de radar 8 (ver localização na figura 39 e legenda na figura 40).

Figura 49 - Exemplos de seções de radar representativas da sedimentação quaternária (ver localização na figura 39 exemplificada pelos lozangos pretos).

Figura 50 - Tipos de padrão de reflexão identificados na ilha do Marajó.

Figura 51 - Mapa de anomalias de Bouguer na margem nordeste brasileira (segundo Rossetti, 2008b). 


\section{LISTA DE TABELAS}

Tabela 1 - Padrões de drenagem básicos e seus significados. (modificada de Howard, 1967).....

Tabela 2 - Padrões de drenagem modificados e seus significados. (modificada de Howard, 1967).

Tabela 3 - Dados estatísticos dos lineamentos morfoestruturais em intervalos de $10^{\circ}$

\section{LISTA DE EQUAÇÕES}

Equação 1 - Lei de Ohm.

Resistividade elétrica

\section{LISTA DE ANEXOS}

Anexo I - Tabelas de campo das $21 \mathrm{SEV}$ coletadas na porção leste da ilha do Marajó

Anexo II - Curvas de inversão das 132 SEV da ilha do Marajó (ver localização na figura 32).

Anexo III - Tabela dos dados de inversão das 132 SEV da ilha do Marajó (ver localização na figura 32 ). Note ( $\rho$ - resistividade; $h$ - espessura; $d$ - profundidade) 


\section{RESUMO}

SOUZA, L. B. S. Evidências tectônicas no leste da ilha do Marajó: integração de dados morfoestruturais e geofísicos. 2010. ?f. Tese de doutoramento - Instituto de Geociências, Universidade de São Paulo, São Paulo.

Tem sido crescente o volume de investigações sugestivas de deformação tectônica no desenvolvimento dos sistemas deposicionais quaternários da ilha do Marajó. Isto é revelado pela combinação de informações sedimentológicas e estratigráficas com análises morfoestruturais. Entretanto, estudos de subsuperfície visando demonstrar a presença de estruturas tectônicas nessas áreas permanecem por ser apresentados. O presente estudo teve o objetivo principal de verificar se estruturas tectônicas sugeridas em superfície no leste da ilha de Marajó têm expressão em subsuperfície rasa, de forma a permitir discutir seu efeito na sedimentação neógena e quaternária, bem como seu mecanismo gerador. Para isto, procedeu-se com um estudo integrando informações geomorfológicas, geofísicas e geológicas. As informações geomorfológicas foram baseadas em dados cartográficos e imagens Landsat, e visou a análise de bacias de drenagem, identificação de anomalias de drenagem e extração e análise de lineamentos morfoestruturais. Dados geofísicos consistiram em sondagem elétrica vertical (SEV) realizada ao longo deste estudo, adicionadas ao reprocessamento de dados disponíveis na literatura. Este estudo foi complementado com a coleta de seções de radar de penetração no solo (GPR). A análise de dados de subsuperfície foi apoiada em estudos geológicos baseados em exposições naturais em falésias, cortes de estrada e pedreiras, além de testemunhos de sondagem. Três bacias de drenagem foram reconhecidas na área de estudo, correspondentes aos rios Arari, Camará e Paracauari. Todas estas bacias mostram evidências de anomalias morfoestruturais, 
incluindo-se principalmente: mudanças rápidas no padrão de drenagem dentro de uma mesma bacia, variando de treliça, retangular, multibacinal a subparalelo; canais retilíneos comumente conectados em ângulos retos; canais meandrantes que se tornam retilíneos; meandros localizados; e bacias altamente assimétricas (fator de assimetria > 60). Anomalias de drenagem consistindo em freqüentes desvios de direção com ângulos retos e meandros isolados e comprimidos, são também reconhecidas na paleodrenagem preservada na área de estudo. Dois compartimentos morfoestruturais puderam ser reconhecidos com base na densidade dos lineamentos estruturais: compartimento I, localizado na porção centro-leste da área de estudo, onde ocorre densidade de lineamentos alta com duas direções preferenciais para NW-SE e NE-SW; e compartimento II, correspondente ao restante da área, onde a densidade de lineamentos é muito baixa a média, e com orientação principal para NE-SW. O estudo enfocando $132 \mathrm{SEVs}$ demonstrou que os extremos leste e sul da área de estudo são extremamente resistivos (valores de até $13.000 \Omega \mathrm{m}$ ), que foram relacionados com a ocorrência, próximo da superfície, de paleossolo laterítico, bem como de estratos ferruginizados logo abaixo deste horizonte, formados em associação com a discordância do topo de estratos miocênicos da Formação Barreiras. Por outro lado, valores baixos $(<90 \Omega \mathrm{m})$ foram registrados no restante da área de estudo, que foram relacionados com depósitos condutivos, representados por litologias argilosas, heterolíticas e, menos comumente, areníticas, correspondentes aos Sedimentos Pós-Barreiras, de idade quaternária tardia e holocênica. Esses dados são condizentes com a análise de seções GPR, que demonstrou refletores de alta freqüência e continuidade lateral próximo da superfície relacionada ao paleossolo laterítico. Com base nesta constatação, pode-se reconhecer duas unidades estratigráficas na porção leste da área de estudo, sendo a inferior relacionada com 
a Formação Barreiras e a superior correspondente aos Sedimentos Pós-Barreiras. Em contraste, as porções leste e norte da área de estudo mostraram ausência de refletores, que foi associado à presença de sedimentos quaternários dominantemente argilosos e contendo água estratal salobra e/ou salina. Várias características suportam a presença de estruturas tectônicas na área de estudo. Isto é sugerido pela abundância de anomalias de drenagem (atual e pretérita) e de lineamentos morfoestruturais com direcionamentos que coincidem com as orientações principais de falhas tectônicas registradas na região amazônica. A presença de falhas foi ainda indicada por contatos bruscos entre a Formação Barreiras e os Sedimentos Pós-Barreiras nas seções SEVs. Esta proposta é consistente com a análise de dados de superfície, que mostrou coincidência dos locais onde ocorrem estes contatos bruscos com lineamentos morfoestruturais. Da mesma forma, as seções GPR revelaram uma abundância de refletores deslocados verticalmente, que são somente justificados considerando-se falhas tectônicas. Adicionalmente, a porção basal de muitas das seções GPR mostraram refletores ondulados, que foram relacionados com amplas dobras sinclinais e anticlinais. A origem dessas estruturas tectônicas é discutida considerando-se três mecanismos potenciais: tectônica andina, tectônica gravitacional relacionada com a sobrecarga do leque submarino do cone do Amazonas, e rifteamento marginal. A hipótese de relacionamento das estruturas tectônicas registradas neste trabalho com a dinâmica de evolução do Sistema de Graben do Marajó aparece como a mais provável. As dobras e falhas registradas na Formação Barreiras e Sedimentos Pós-Barreiras podem ser explicadas considerando tectônica transcorrente, com associação de deformação transpressiva e transtensiva durante e após o Mioceno. 
Palavras-chave: lineamentos morfoestruturais, sondagem elétrica vertical, unidades de radar, tectônicas, ilha do Marajó, Quaternário. 


\begin{abstract}
SOUZA, L. B. S. Evidence of tectonics in eastern Marajó island: integration of morfoestructural and geophysical data. 2010. ?f. Tese de doutoramento - Instituto de Geociências, Universidade de São Paulo, São Paulo.
\end{abstract}

There has been an increasing volume of investigation suggestive of tectonic deformation in the development of Quaternary depositional systems in Marajó island. This is revealed by a combination of sedimentological and stratigraphical information with morphostructural analysis. However, subsurface studies aiming to demonstrate the presence of tectonic structures in this area remain to be presented. The present study had the main goal of verifying if tectonic structures suggested in surface in eastern Marajó island are expressed in shallow subsurface, thus allowing to discuss their effect in the Neogene and Quaternary sedimentation, as well as their trigger mechanism. This was approached with a study integrating geomorphologic, geophysical and geological information. Geomorphological information, based on cartographic data and Landsat images, aimed analysis of drainage basins, identification of drainage anomalies and extraction and analysis of morphostructural lineaments. Geophysical data consisted of vertical electric sounding (VES) acquired along this study, added to the reprocessing of data available in the literature. This study was complemented with acquisition of ground penetrating radar (GPR) sections. SEV data collected along this study were combined with reprocessed data derived from available literature. The geophysical study includes also acquisition of ground penetration radar (GPR) sections. The analysis of subsurface data was complemented with geological studies of based on natural exposures along coastal cliffs, road cuts and quarries, as well as cores. Three drainage basins were recognized in the study area, corresponding to 
the Arari, Camará and Paracauari rivers. All these basins show evidence of morphostructural anomalies, mostly including: rapid changes in drainage pattern within a same basin, ranging from trellis, rectangular, multibasin to subparallel; straight channels commonly connected at right angles; meandering channels that change to straight channels; local meandering; and highly asymmetric basins (asymmetry index $>60$ ). Drainage anomalies consisting of frequent changes in river courses forming straight angles and isolated and compressed meanders are also recorded in the paleodrainage preserved in the study area. Two morphostructural compartments were recognized with basin morphostructural lineament density: compartment I, situated in the center-eastern part of the study area, where lineament density is high and with two preferential directions to NWSE and NE-SW; and compartment II, corresponding to the remaining of the area, where lineament density is low to moderate, and with a NE-SW main trend. The study focusing on 132 VESs revealed that the eastern and southern portions of the study area are extremely resistive (values up to $13.000 \Omega \mathrm{m}$ ). This is related to the occurrence of lateritic paleosol near the surface, as well as ferrified strata immediately underlying this horizon, which were formed in association with the unconformity at the top of the Miocene strata of the Barreiras Formation. In contrast, only low resistivity values $(<90 \Omega \mathrm{m})$ were recorded in the remaining of the study area, being related to conductive deposits represented by muddy, heterolithic and, less commonly, sandy lithologies corresponding to the Post-Barreiras Sediments of late Quaternary and Holocene ages. These data are consistent with analysis of GPR sections, which revealed reflectors with high frequency and lateral continuity near the surface associated with the lateritic paleosol. Taking this into account, two stratigraphic units were recognized in the eastern portion of the study area, with the lower one related to 
the Barreiras Formation and the upper one corresponding to the Post-Barreiras Sediments. In constrast, the eastern and northern portions of the study area displayed absence of reflectors, which was associated with the presence of dominantly muddy Quaternary sediments bearing intrastratal brackish and/or saline waters. Several characteristics support the presence of tectonic structures in the study area. This was suggested by the abundance of drainage anomalies (modern and ancient) and morphostructural lineaments with directions that coincide with the orientation of main tectonic faults recorded in Amazonia. The presence of faults was also indicated by sharp contacts between the Barreiras Formation and the Post Barreiras Sediments, as recorded in the VES sections. This proposal is consistent with the analysis of surface data that shows concordance of the places with sharp lithological contacts with morphostructural lineaments. Likewise, the GPR sections reveal an abundance of reflectors with vertical offsets that are only justified taking into account tectonic faults. Additionally, the basal portions of several GPR sections displayed undulatory reflectors, which were related to wide syncline and anticline folds. The origin of these tectonic structures is discussed considering three potential mechanisms: Andean tectonics, gravitational tectonics related to sediment loading in the Amazon submarine cone, and marginal rifting. The hypothesis of relating the tectonic structures recorded in this work with the dynamic evolution of the Marajo Graben System seems the most likely. The folds and faults recorded in the Barreiras Formation and Post-Barreiras Sediments might be explained considering strike slip deformation, with association of transpression and transtension during and after the Miocene.

Key-words: morphostructural lineaments, vertical electric sounding, radar units, Marajó island, Quaternary. 


\section{INTRODUÇÃO}

A ilha do Marajó, localizada na foz do rio Amazonas, representa uma área de cotas topográficas rebaixadas quase ao nível do mar, cuja evolução sedimentar foi caracterizada por grande dinamismo durante o Quaternário. Isto é revelado, principalmente, por uma abundância de paleocanais, excepcionalmente bem preservados na paisagem da ilha, e passíveis de serem detectados até mesmo sob densa cobertura vegetal utilizando-se modelo digital de elevação derivado do Shuttle Radar Topography Mission (MDE-SRTM) (Rossetti \& Valeriano, 2007; Mantelli, 2008; Rossetti et al. 2008 a, b; Mantelli \& Rossetti, 2009).

Vários trabalhos prévios mostram a importância de controle estrutural no estabelecimento da rede de drenagem da ilha do Marajó (p.e., Costa et al. 1996, 2002; Villegas, 1994; Bemerguy, 1981, 1997). Trabalhos mais recentes integrando dados de sensoriamento remoto e sedimentológico-estratigráficos (p.e, Rossetti et al. 2008a, b; Rossetti \& Valeriano, 2007; Rossetti, 2010) são concordantes com esta proposição. Em particular, a caracterização de estruturas deformacionais sin-sedimentares e a correlação de testemunhos de sondagem apresentada nestes artigos sugerem que a ação tectônica na margem leste da ilha do Marajó teria resultado na geração de espaço de acomodação durante o Pleistoceno tardio e Holoceno, proporcionando a retomada da sedimentação após longo intervalo de não deposição que se seguiu à sedimentação miocena.

Apesar de vários trabalhos anteriores destacarem a importância de reativações tectônicas recentes na ilha do Marajó, ainda não existem estudos que demonstrem a presença física de estruturas tectônicas integrando-se dados de superfície e subsuperfície. Dada à carência de afloramentos naturais na ilha decorrentes da baixa topografia, estudos 
deste gênero requerem o emprego de técnicas de investigação indireta utilizando-se, por exemplo, anomalias e lineamentos morfoestruturais derivados da rede de drenagem atual e palimpsesta, que possam ser integrados com dados de subsuperfície aplicando-se técnicas geofísicas. Estudo detalhado abordando propriedades de drenagem foi realizado somente na porção sudeste da ilha do Marajó (Mantelli \& Rossetti, 2009). Para a porção leste da ilha, a coleta deste tipo de informação foi feita apenas de forma genérica (Bemerguy, 1997; Rossetti et al. 2007) em complementação a outros tipos de estudo. Por outro lado, a coleta de dados geofísicos nessa área consiste em sondagem elétrica vertical (SEV) (p.e., Trancredi, 1972; Bezerra, 1979; Cavalcanti, 1979; Kobayashi, 1979; Gonzáles, 1984; IDESP, 1974 e 1986; Porsani, 1981; Carrasquila et al. 1991), bem como poucos estudos enfocando sísmica de refração e método eletromagnético (i.e., Guimarães, 1983; Verma \& Bischoff, 1989). Embora tendo visado, em geral, a prospecção de água subterrânea, os resultados advindos destes estudos sugerem locais na ilha do Marajó onde a sedimentação quaternária é bastante expressiva, atingindo profundidades de até $100 \mathrm{~m}$, o que leva a suspeitar na presença de áreas subsidentes proporcionadas, provavelmente, por falhas tectônicas. Isto leva a antecipar que esses métodos geofísicos, principalmente aplicando-se SEV, tenham bom potencial de aplicação na ilha.

SEV é um método rápido, barato e de boa aplicabilidade em terrenos sedimentares (p.e., Mendes, 2002; Cutrim \& Rebouças, 2005; Souza, 2005; Oliva \& Kiang, 2007; Bello et al. 2010), tendo elevado potencial para a caracterização de feições tectônicas em subsuperfície rasa (Santos, 2003; Freitas Filho, 2006; Özürlan et al. 2006; Costa \& Malagutti Filho, 2008). Além disto, vários estudos aplicando radar de penetração no solo (GPR) têm demonstrado grande sucesso no mapeamento de estruturas tectônicas em subsuperfície rasa em estratos correlatos do nordeste do Estado do Pará (Rossetti \& Góes, 
2001; Rossetti et al. 2001; Rossetti, 2003). Similarmente à SEV, a coleta de dados GPR é rápida e de baixo custo, podendo servir como ferramenta adicional na caracterização de estratos sedimentares e na detecção de feições tectônicas em subsuperfície rasa. A associação destes métodos, quando aplicados em áreas com conhecimento geológico prévio, é de grande potencial para testar se estruturas tectônicas sugeridas em superfície com base em dados geomorfológicos têm expressão física em subsuperfície rasa.

\section{OBJETIVOS}

O presente trabalho objetivou demonstrar se estruturas tectônicas sugeridas em superfície têm expressão em subsuperfície rasa no leste da ilha do Marajó, de forma a permitir discutir seu efeito na sedimentação neógena e quaternária, bem como o modelo geotectônico mais provável, tomando-se por base a integração de dados geomorfológicos, geológicos e geofísicos.

Objetivos específicos incluem:

(a) Estabelecer o local de ocorrência de estruturas tectônicas em superfície e suas tendências direcionais com base na detecção de anomalias de drenagem e no mapeamento de lineamentos morfoestruturais derivados da integração de dados de sensoriamento remoto com mapas de drenagem disponíveis no sistema de dados SIVAM/IBGE;

(b) Detectar estruturas tectônicas por meio da análise da distribuição das unidades sedimentares em subsuperfície rasa baseada em características litológicas derivadas de propriedades de resistividade registradas por método de SEV; 
(c) Detectar estruturas tectônicas em subsuperfície rasa com base na configuração, geometria e continuidade física de reflexões eletromagnéticas derivadas de seções GPR, analisando a distribuição espacial dos estratos sedimentares, bem como identificando e correlacionando superfícies estratigráficas chaves.

\section{CARACTERIZAÇÃO DA ÁREA DE ESTUDO}

\subsection{Generalidades e Vias de Acesso}

A ilha do Marajó situa-se no nordeste do Estado do Pará, extremo norte do Brasil, a $87 \mathrm{~km}$ de Belém entre os paralelos $0^{\circ}$ e $2^{\circ} \mathrm{S}$ e os meridianos $48^{\circ}$ e $51^{\circ} \mathrm{W}$ (Figura 1). Esta área, de $49.606 \mathrm{~km}^{2}$, faz parte do complexo flúvio-marinho da foz do rio Amazonas. A ilha é limitada pelo rio Amazonas, a norte, rios Pará e Tocantins, a sul, e Oceano Atlântico, a leste, sendo um dos mais importantes santuários ecológicos do planeta. A exuberância da sua paisagem, formada por florestas, campinas e savanas entre rios, lagos, furos e igarapés, é notável. Entre a ilha e Belém, se estende a baía de Marajó, com 18 km de largura, formada por mistura de água salgada do Atlântico e água doce dos rios Pará e Tocantins (Faustino, 2002).

A área de estudo compreende os municípios de Salvaterra, Cachoeira do Arari e Joanes. O acesso à área pode ser feito por via fluvial, através da baía de Marajó (percorrido em cerca de 3 a 4 horas, dependendo da maré), chegando-se ao porto fluvial do município de Salvaterra e seguindo-se, por via terrestre, em estrada pavimentada, até a cidade homônima. A região de Salvaterra tem quase $1.044 \mathrm{~km}^{2}$, fica entre $00^{\circ} 45^{\prime} \mathrm{S}$ e $48^{\circ} 30^{\prime} \mathrm{W}$, sendo margeada pelo rio Paracauari e a baía do Guajará. É limitada pelos municípios de 
Soure, a norte, e Cachoeira do Arari, a sul. O município de Cachoeira do Arari ocupa área de $3.116 \mathrm{~km}^{2}$, estando posicionado entre $01^{\circ} 00^{\prime} 36^{\prime \prime} \mathrm{S}$ e $48^{\circ} 57^{\prime} 36^{\prime \prime} \mathrm{W}$. A norte limita-se com os municípios de Chaves, Soure e Santa Cruz do Arari; a sul com a baía de Marajó; a leste com o município de Salvaterra; e a oeste com o minicípio de Ponta de Pedras. A área de Joanes situa-se entre $0^{\circ} 50^{\prime} \mathrm{S}$ e $48^{\circ} 30^{\prime} \mathrm{W}$, sendo limita pelos municípios de Salvaterra e Soure, a norte; rio Camará, a oeste; e baía de Marajó, a leste e sul (Figura 1).

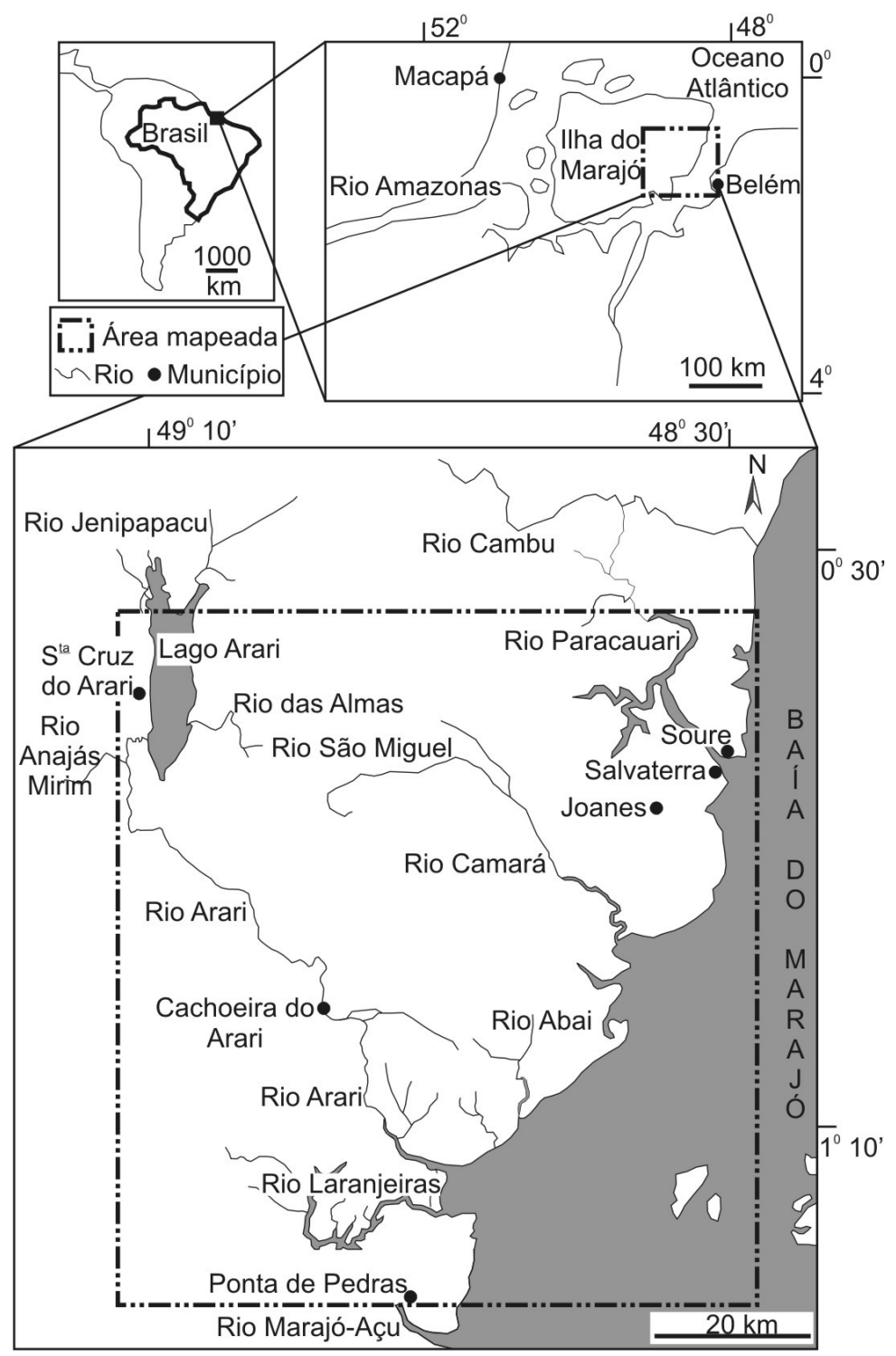

Figura 1 - Mapa de localização da área de estudo na porção leste ilha do Marajó. 


\subsection{Aspectos Fisiográficos}

\subsubsection{Clima}

A classificação climática da área de estudo, segundo Köppen, é do tipo Ami-tropical chuvoso, com precipitação anual média de 2.500-3.200 mm e umidade relativa do ar de 7885\% (DNMET, 1992; Teixeira Neto et al. 1991). O clima equatorial úmido caracteriza-se por temperatura média em torno de $27^{\circ} \mathrm{C}$, mínima superior a $18^{\circ} \mathrm{C}$ e máxima de $36^{\circ} \mathrm{C}$, com pluviosidade elevada nos seis primeiros meses do ano (IDESP, 1974).

\subsubsection{Solo}

Os solos de maior expressão na ilha são os hidromórficos indiscriminados e hidromórficos gleyzados (Correa et al. 1974). Os primeiros apresentam perfis com horizonte superficial orgânico e orgânico-mineral, com grande variação em espessura, nos quais a matéria orgânica está total ou parcialmente decomposta. Este tipo de solo é pouco evoluído, medianamente profundo, pouco poroso, ácido, com baixa capacidade de troca de cátions e saturação de bases. Já os gleyzados são constituídos por solos desenvolvidos sobre sedimentos relativamente recentes, em geral fortemente ácidos, podendo apresentarse neutros e alcalinos, de textura argilosa e, às vezes, com considerável conteúdo de silte. Adicionalmente, solos halomórficos ocorrem no litoral da ilha, sendo eles de pouca expressão e representados por solos indiscriminados de mangue (Bemerguy et al. 2003). 


\subsubsection{Topografia}

A topografia da ilha é tipicamente plana, com pequenos desníveis, apresentando duas áreas distintas: os campos baixos que permanecem inundados seis meses ou mais por ano, e terrenos ligeiramente mais elevados que não são atingidos pelas cheias. Dados de cotas altimétricas em mapas e cartas topográficas são raros ou inexistentes, sendo as estimativas em torno de 2-42 m. MDE-SRTM indica cotas variando entre 4 e $6 \mathrm{~m}$ na porção leste da ilha, e entre 6 e $38 \mathrm{~m}$ em sua porção oeste, com valor médio geral de $12 \mathrm{~m}$ (Rossetti \& Valeriano, 2007).

A geomorfologia da ilha do Marajó é caracterizada por: planícies fluviais colmatadas em sua porção leste e oeste; e superfícies pediplanadas em sua porção central. Estas feições fazem parte das unidades morfoestruturais denominadas de Planalto Rebaixado da Amazônia e Planície Amazônica. O Planalto rebaixado da Amazônia abrange toda a porção centro-sul da ilha, sendo limitado a oeste com as planícies fluviais em processo de colmatagem, e a leste com as planícies fluviais colmatadas. A Planície Amazônica apresenta um conjunto particular de paleocanais, furos, igarapés, paranás e lagos (Bemerguy et al. 2003). De acordo com estes autores, a ilha faz parte do Compartimento Morfotectônico Marajoara, sendo sua evolução vinculada à movimentação transtensiva do Terciário Superior, que se prolongou até o Quaternário, e controlou a estruturação e organização da paisagem. 


\subsubsection{Vegetação}

$\mathrm{Na}$ porção oriental da ilha ocorre vegetação não florestal (campo natural inundável, savana parque ou arborizada, campo cerrado e campo de murundu ou "mondongo"). Já na parte oriental, predominam florestas ombrófilas dos tipos densa aluvial e densa de terras baixas (IDESP, 1974).

Devido à prática da agricultura migratória, manchas de floresta secundária ocorrem em meio à floresta densa, onde os cultivos foram abandonados. Os campos naturais constituem-se em gramíneas, tais como capim de marreca (Paratheria prostrata Griseb.), várias canaranas (Echinochloa polystachya (H.B.K.) Hitch.) e ciperáceas, sobressaindo o piri (Cyperus giganteus Vahl.). O cerrado, com fisionomia de parque, ocupa algumas das áreas emersas, cujo principal componente é o capim barba-de-bode (Andopogon virgicus L.). No extrato arbóreo ou arbustivo, as principais espécies são a mangaba (Hancornia speciosa Gam.), o caimbé (Curatella americana L.) e o muruci (Byrsonima crassifolia H. B. K.), além das matas de galeria, onde as palmeiras, como o buriti (Mauritia flexuosa L.), o tucumã (Astrocaryum vulgare Mart.) e o açaí (Euterpe oleracea Mart.), são os mais comuns. No litoral ocorrem densas florestas aluviais (várzea), com árvores como a ucuúba (Virola surinamensis Warb.), o açaí (Euterpe oleracea Mart.), a andiroba (Carapa guianensis Aubl.), o buruti (Mauritia flexuosa L.) e os manguezais, onde predomina o mangue vermelho (Ryzophora mangle L.), a aninga (Montrichardia arborescens Shott.) e o aturiá (Machaerium lunatum L.) (IDESP, 1974; Barbosa, 2003). 


\subsubsection{Hidrografia}

A rede de drenagem na ilha do Marajó apresenta escoamento geral do centro para as bordas. Em sua porção ocidental, a drenagem é do tipo radial densa, onde a angularidade dos rios de primeira ordem é baixa e a sinuosidade curva, enquanto que os de primeira e segunda ordens, que confluem diretamente nos de ordem mais alta, têm angularidade média e sinuosidade mista (Bemerguy et al. 2003).

A drenagem do município de Salvaterra é representada principalmente pelo rio Paracauari, o qual corre de oeste para leste, servindo de limite, em grande parte, com o município de Soure, a norte. Este rio segue seu curso apresentando-se meandrante, principalmente, em segmentos localizados a alguns quilômetros da foz. Seu maior afluente é o rio Maichará, que possui dois outros afluentes: os rios Nazaré e Mangueira. Outro rio de expressão no município é o rio Camará, que serve de limite natural entre Salvaterra e Cachoeira do Arari. Esse rio corre de noroeste para sudeste, apresentando, também, seu baixo curso com características meândricas (SEPOF, 2004).

Na drenagem do município de Cachoeira do Arari, destaca-se o rio Arari, que serve de limite natural, a oeste, com o município de Ponta de Pedras. Outro rio de destaque é o rio Camará, que serve de limite natural, a leste, com o município de Salvaterra. Os rios Arari e Camará deságuam na baía de Marajó, a sudeste do município (IDESP, 1974). 


\section{CONTEXTO GEOLÓGICO}

A ilha do Marajó insere-se, em sua porção oeste, no Sistema de Graben do Marajó (SGM), e em sua porção leste na Plataforma do Pará (PP). O SGM localiza-se na parte norte do Estado do Pará e possui forma alongada de direção NW-SE. Este graben apresenta feições geológicas e geomorfológicas características à distensão mesozóica e à neotectônica pós-miocena. A disposição do depocentro do SGM e de suas falhas associadas sugere arquitetura em semi-graben, com formação de subbacias separadas por falhas direcionais ENE e NE-SW (Villegas, 1994).

O evento de distensão, com fases no Cretáceo Inferior e Superior, originou quatro subbacias (Mexiana, a norte, Limoeiro, no centro, e Cametá e Mocajuba, a sul). Falhas normais NW e NNW e direcionais NE e ENE controlaram a geometria da bacia (Costa et al. 2002). A distensão relacionada com a abertura do Atlântico Equatorial propagou-se continente adentro ao longo de zonas de fraqueza crustal dos cinturões orogênicos précambrianos Tumucumaque, Amapá e Araguaia (Figura 2). 


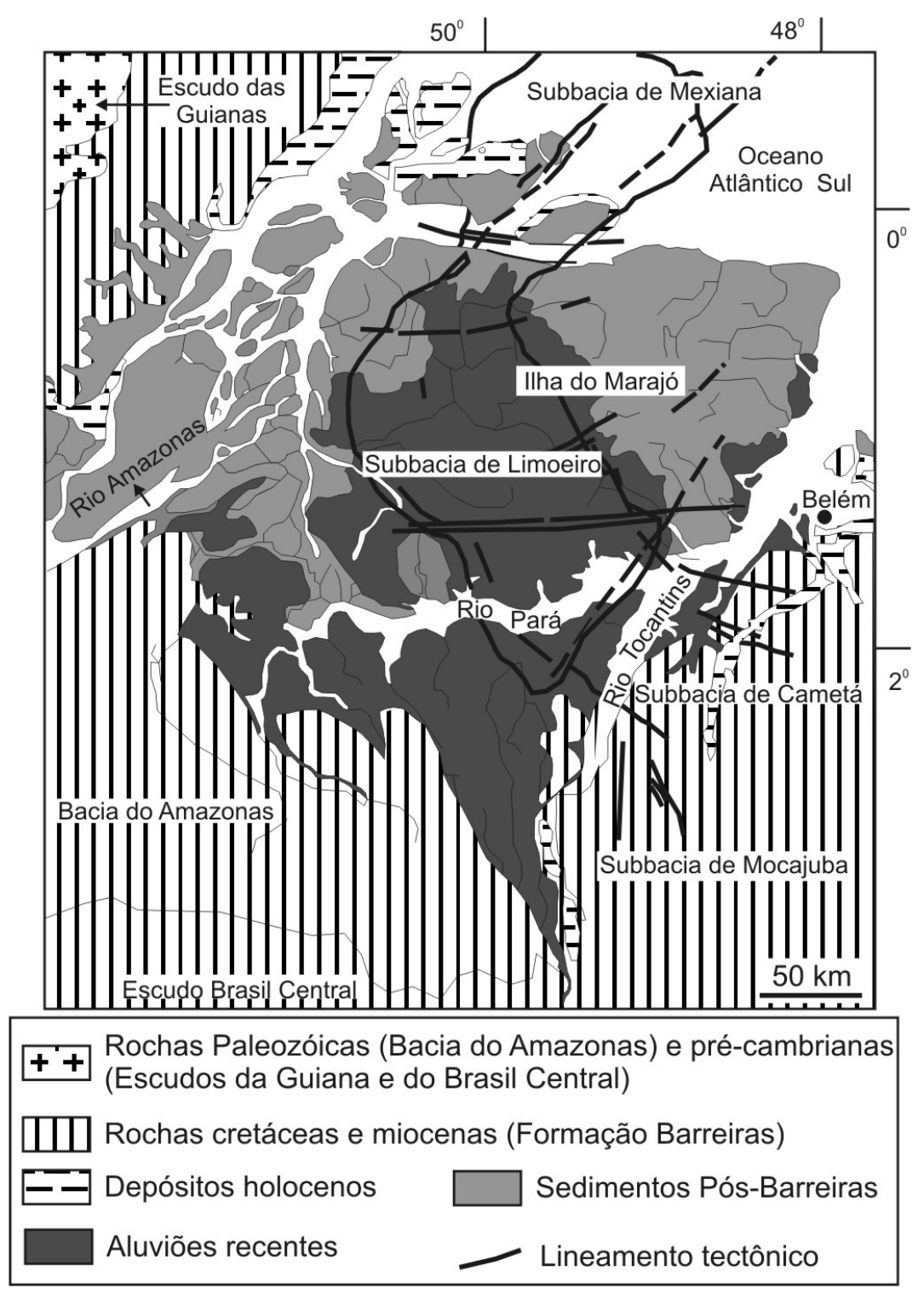

Figura 2 - Mapa geológico do baixo rio Tocantins-ilha do Marajó. (modificada de Rossetti \& Toledo, 2006).

Pesquisa regional inseriu a ilha do Marajó no Compartimento Estrutural Marajoara (Bemerguy, 1997), que abrange um conjunto de falhas normais de direção NW-SE, segmentadas por zonas de falhas direcionais dextrais orientadas para NE-SW e ENEWSW/E-W. Análise morfoestrutural sugere fase tectônica importante de direção 
NNW/N/NNE-SSE/S/SSW (Rossetti et al. 2007). De acordo com esses autores, eventos subseqüentes resultaram em lineamentos de direção NW-SE e NE-SW, sendo que os primeiros resultaram em leve depressão no lado oriental da ilha. Os lineamentos morfoestruturais da ilha estão em acordo com as direções dos principais sistemas de falha reativados entre o Terciário e o Holoceno ao longo da Amazônia Brasileira (p.e., Costa \& Hasui, 1997, Góes \& Rossetti, 2001; Costa et al. 1993, 1995, 1996, 2001, 2002; Bemerguy et al. 2002; Bezerra, 2003).

O arcabouço estratigráfico do SGM consiste em um pacote de rochas sedimentares formadas deste o Cretáceo Inferior até o recente, atingindo espessuras na ordem de $11 \mathrm{~km}$. A sucessão pré-rift inclui processos geológicos anteriores à instalação da bacia, e compreende dois grupos de rochas que constituem seu embasamento. O primeiro grupo está ligado às rochas gnáissicas granulíticas alternadas com supracrustais, gnáissicas migmatizadas e granitóides dos cinturões pré-cambrianos Tumucumaque, Gurupi e Araguaia, adjacentes à bacia. Já o segundo grupo consiste em rochas sedimentares que foram depositadas durante o Paleozóico. A sucessão sin-rift inclui sedimentos clásticoarenosos da Formação Breves (Albiano) e, na parte oeste da ilha, clásticos grossos e seixos aluviais da Formação Jacarezinho (Aptiano-Cenomaniano), além de siltitos e argilitos da Formação Anajás (Eocretáceo) (Avenius, 1988). Estas unidades são atribuídas a ambientes que variam de fluvial a marinho raso e aluvial (Villegas, 1994).

A sucessão pós-rift corresponde aos sedimentos terciários das formações Limoeiro (Cretáceo Superior), Marajó (Paleoceno-Eoceno), e Tucunaré (Quaternário) (Villegas, 1994). A Formação Limoeiro, que é atribuída a ambientes variando de fluvial a marinho raso, corresponde litoestratigraficamente a arenitos friáveis, finos a grossos, com freqüentes níveis conglomeráticos e intercalações de argilitos. A Formação Marajó consiste em uma 
unidade carbonático-siliciclástica, e a Formação Tucunaré inclui arenitos quartzosos intercalados a argilitos, sendo ambas atribuídas a ambiente marinho raso e transicional (Figura 3).

A porção leste da ilha do Marajó encontra-se inserida na PP, que corresponde a uma extensa área do embasamento que permaneceu tectonicamente estável entre as bacias paleozóicas do Amazonas e Parnaíba, cujos limites são os arcos de Gurupá e Tocantins. Essa plataforma apresenta pequenas fossas com profundidades na ordem de $3.500 \mathrm{~m}$ (Rezende \& Ferradaes, 1971). O lago Arari ocorre sobre uma dessas depressões, que tem direção norte-sul, e se estende para norte, onde se conecta com a subbacia de Mexiana (Azevedo, 1991).

Em superfície, a porção leste da ilha é composta por depósitos miocenos (sucessão Pirabas/Barreiras), além de depósitos denominados de Pós-Barreiras (Plio-Pleistoceno). A Formação Pirabas consiste em uma sucessão de fácies carbonáticas com intercalações de folhelhos e arenitos, atribuídos a ambiente marinho raso plataformal restrito, bem como lagunas e mangues conectados a ambiente estuarino (Góes et al. 1990). A Formação Barreiras é constituída de arenitos maciços a estratificados, argilitos laminados a maciços e pelitos com acamamentos heterolíticos, cuja origem é atribuída a ambiente estuarino (Arai et al. 1988; Rossetti \& Truckenbrodt, 1989; Rossetti, 2000a, b; Rossetti, 2001). Os Sedimentos Pós-Barreiras englobam arenitos finos a médios, maciços e de coloração amarelada, atribuídos a processos gravitacionais e eólicos (Rossetti \& Truckenbrodt, 1989). 


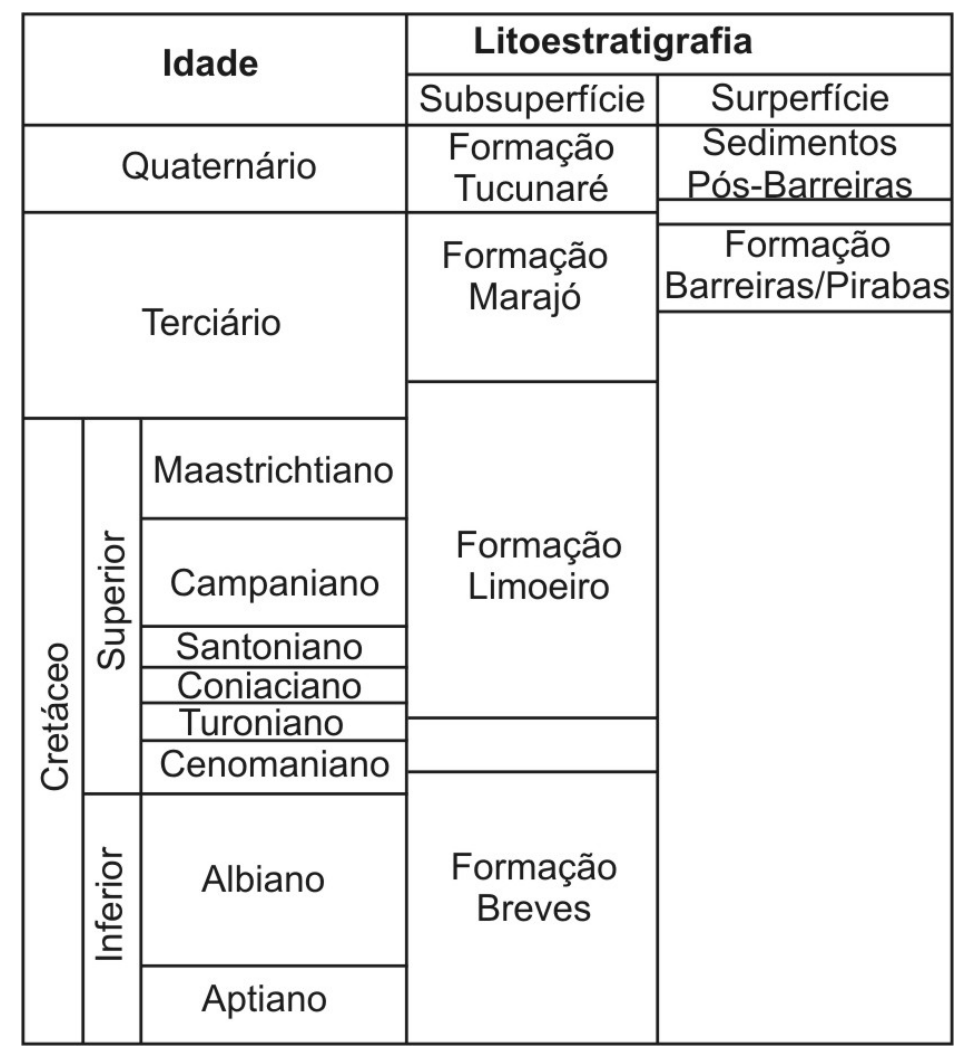

Figura 3 - Coluna estratigráfica do Sistema de Graben do Marajó. (modificada de Rossetti \& Valeriano, 2007).

Pesquisas recentes têm sugerido que grande parte dos Sedimentos Pós-Barreiras acima descritos foi depositada em paleovale inciso em rochas miocenas e mais antigas, cujas margens são definidas por falhas tectônicas (Rossetti \& Valeriano, 2007). De acordo com estes autores, o rio Tocantins, então posicionado a oeste de seu curso atual durante o Pleistoceno, transportava sua carga sedimentar na direção NNW, alimentando este paleovale. Este sistema de drenagem teria sido abandonado à medida que houve captura do curso do rio Tocantins para sua posição atual NE-SW, resultando em uma extensa rede de paleocanais, que são ainda bem preservados na paisagem da ilha. Este processo teria culminado, ainda, com a separação da ilha do Marajó do continente, e no abandono do 
paleoestuário Arari, este dado pela interrupção do influxo fluvial oriundo das áreas continentais (Rossetti et al. 2008a). As atividades tectônicas que resultaram no desvio do rio Tocantins para nordeste, também parecem ter sido responsáveis por uma leve subsidência da margem leste da ilha (Rossetti \& Toledo, 2006; Rossetti \& Valeriano, 2007; Rossetti et al. 2008 a, b).

Após deposição dos Sedimentos Pós-Barreiras, formaram-se depósitos sedimentares pelíticos a psamíticos ligados à evolução atual dos sistemas de drenagem e do litoral. Os depósitos fluviais incluem terraços, canais e planícies de inundação. No litoral, aparecem depósitos vinculados a pântanos e mangues, terraços marinhos, barras litorâneas, campos de dunas, praias e cordões litorâneos (Costa et al. 1996).

\section{FUNDAMENTAÇÃO TEÓRICA}

Este capítulo visa apresentar conceitos básicos relacionados com os estudos de superfície e subsuperfície realizados nesta pesquisa com o intuito de registrar estruturas tectônicas na porção leste da ilha do Marajó. O registro dessas estruturas em superfície pode ser sugerida com base na caracterização das propriedades de drenagem, identificação de anomalias de drenagem e mapeamento de lineamentos morfoestruturais a partir da integração de mapas de drenagem com dados orbitais. Portanto, este capítulo será iniciado com a fundamentação de parâmetros utilizados na caracterização de bacias de drenagem e do produto de sensoriamento remoto utilizado como complementação à extração desses dados. A caracterização de estruturas tectônicas em subsuperfície rasa foi feita com basena interpretação de dados de SEV e de GPR, portanto a sequiência deste capítulo incluirá a 
apresentação dos princípios desses métodos e suas principais aplicações. O objetivo é fazer com que o leitor, mesmo não especializado em determinado tema, possa ter plena compreensão dos dados a serem apresentados e discutidos em capítulos subseqüentes.

\subsection{Análise de Bacias de Drenagem}

Bacias de drenagem podem ser descritas pelo padrão de drenagem (considerando conjuntos de canais), que mostra a disposição espacial dos rios, controlada, em grande parte, pelas características geológicas (Howard, 1967). O escoamento fluvial se constitui em um dos parâmetros utilizados na classificação de bacias de drenagem (Christofoletti, 1980), as quais podem ser dos tipos: (a) exorréicas - modo contínuo até o mar ou oceano, isto é, quando as bacias desembocam diretamente no nível marinho; (b) endorréicas - as drenagens são internas e não possuem escoamento até o mar, desembocando em lagos ou dissipando-se nas areias do deserto, ou perdendo-se nas depressões cársticas; (c) arréicas não há estruturação em bacias hidrográficas, como nas áreas desérticas onde a precipitação é insignificante e a atividade dunária é intensa, obscurecendo as linhas e os padrões de drenagem; e (d) criptorréicas - as bacias são subterrâneas, como nas áreas cársticas.

Os caracteres descritivos de drenagem freqüentemente utilizados são: integração, continuidade, densidade, tropia, controle, sinuosidade, angularidade, ângulo de junção e assimetria (Howard, 1967) (Figura 4). Destes, os graus de integração, continuidade e de densidade, possuem implicações diretas com o tipo litológico, ao passo que os demais permitem a identificação de anomalias sugestivas de controle estrutural (p.e., Deffontaines \& Chorowicz, 1991). 


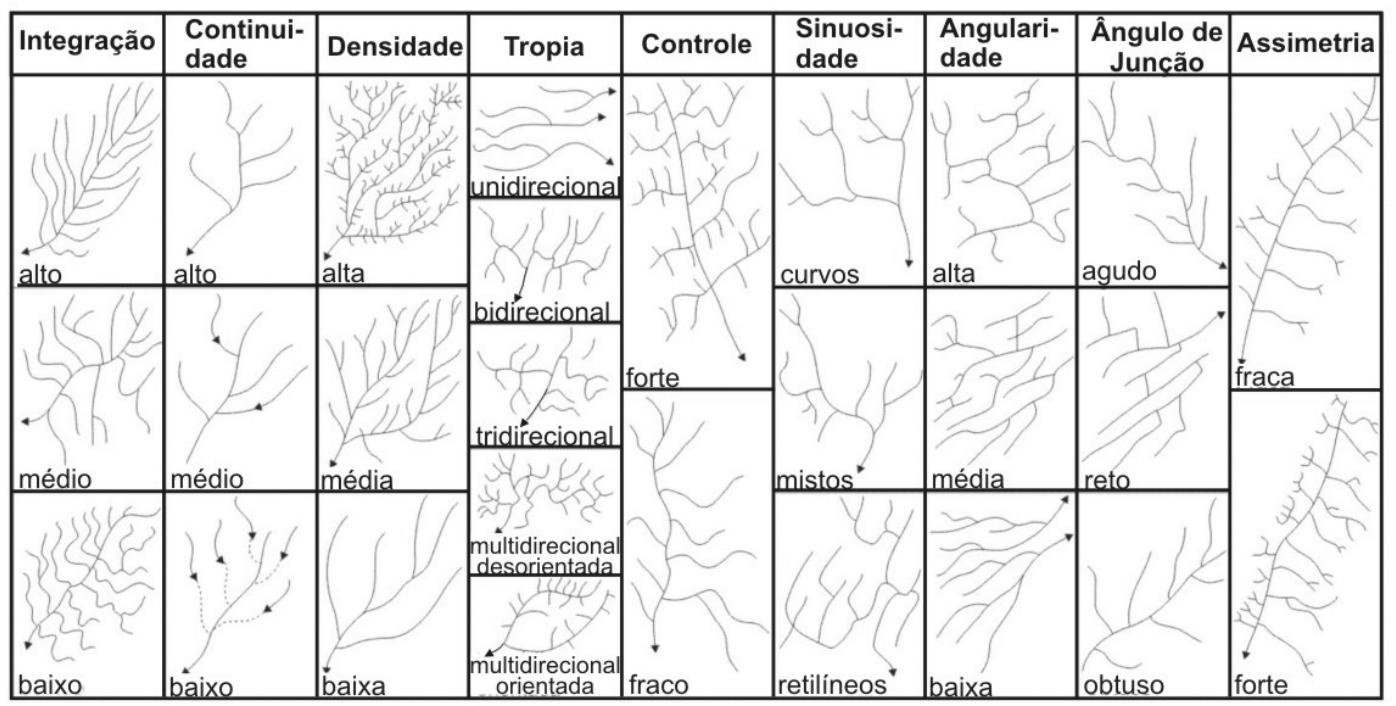

Figura 4 - Principais propriedades de drenagem. (modificada de Soares \& Fiori, 1976).

Os padrões de drenagem que consistem no trajeto formado por drenagens interrelacionadas, mostram inúmeras classificações na literatura (p.e., Howard, 1967; Christofoletti, 1980 e 1981; Cunha, 1994) (Figura 5 e Tabelas 1 e 2). 

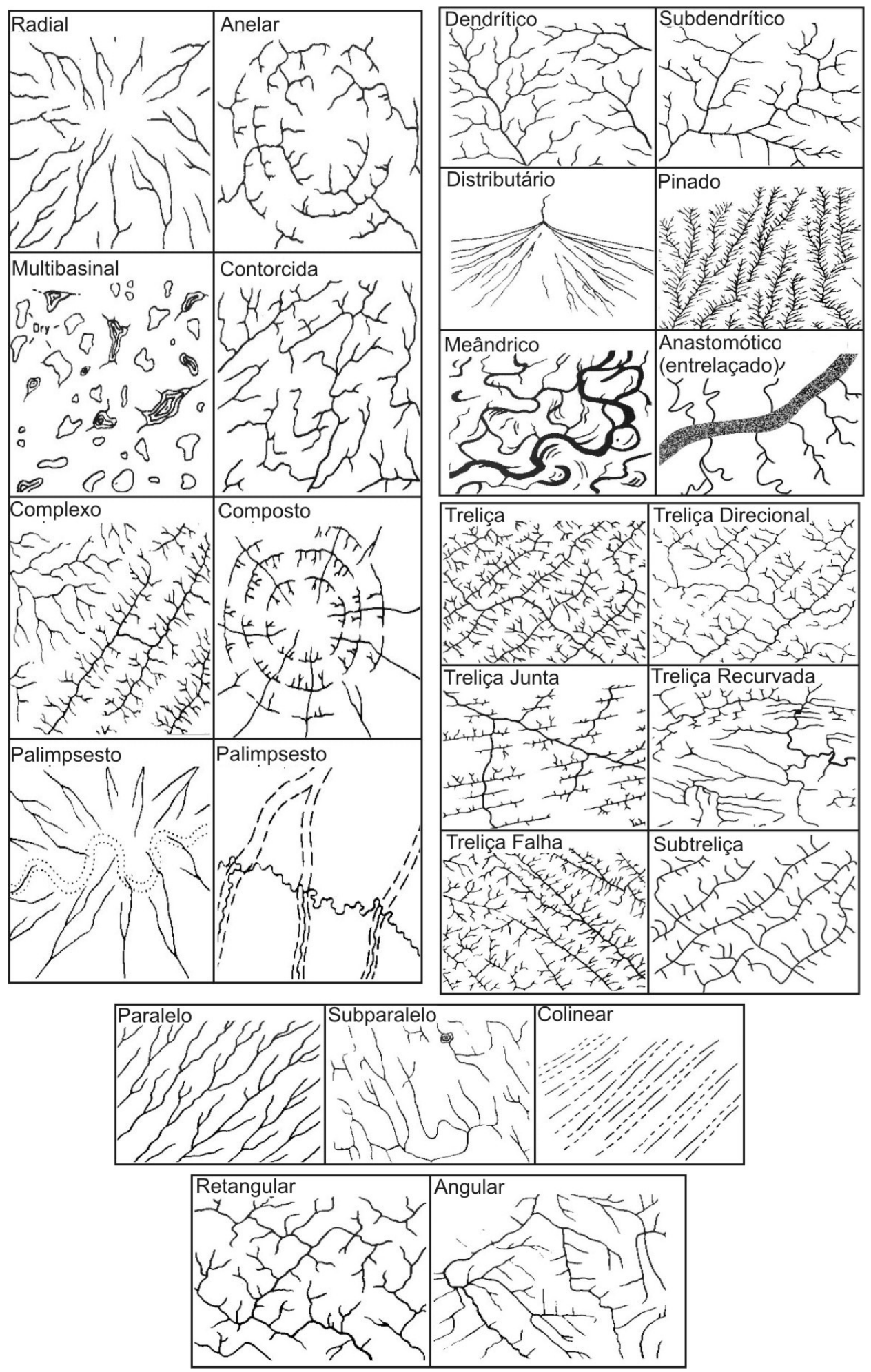

Figura 5 - Tipos de padrões de drenagem. (modificada de Howard, 1967). 
Tabela 1 - Padrões de drenagem básicos e seus significados. (modificada de Howard, 1967).

\begin{tabular}{|c|c|c|}
\hline \multicolumn{3}{|c|}{ TIPOS BÁSICOS DE PADRÕES DE DRENAGEM } \\
\hline TIPO & MORFOLOGIA & CAUSAS \\
\hline Dendrítico & $\begin{array}{l}\text { - ramos irregulares em todas as direções e semelhantes a uma árvore. } \\
\text { - junção do canal principal com os tributários em ângulos variados. } \\
\text { - os rios (i.e., canais) são inseqüentes em origem } \\
\text { - nenhum rio é conseqüente. }\end{array}$ & $\begin{array}{l}\text { - o declive é o fator controlador. } \\
\text { - as rochas oferecem resistência uniforme em superfícies horizontais } \\
\text { (planos, platôs, rochas cristalinas maciças). } \\
\text { - rochas que sofreram intenso metamorfismo. } \\
\text { - a drenagem dendrítica implica em carência ou ausência de controle } \\
\text { estrutural significante. }\end{array}$ \\
\hline Treliça & $\begin{array}{l}\text { - tributário secundário paralelo ao canal principal ou outro canal para qual o } \\
\text { tributário primário conflui. } \\
\text { - tributário secundário alongado e em ângulo reto em relação ao tributário } \\
\text { primário. } \\
\text { - situa-se entre o padrão dendrítico e o retangular. } \\
\text { - a drenagem treliça compreende rios subseqüentes conectados por } \\
\text { reseqüentes ou obseqüentes. }\end{array}$ & $\begin{array}{l}\text { - a drenagem como um todo é conseqüente em origem, podendo } \\
\text { localmente assumir o padrão de treliça como um resultado de } \\
\text { glaciação. } \\
\text { - característico de estratos dobrados ou basculados, e em planície } \\
\text { costeira dissecada. } \\
\text { - rochas sedimentares, vulcânicas ou metassedimentares de baixo } \\
\text { grau, inclinadas ou dobradas. } \\
\text { - áreas de fraturas paralelas. }\end{array}$ \\
\hline Paralelo & $\begin{array}{l}\text { - canais aproximadamente paralelos uns aos outros. } \\
\text { - planícies de lagos, planícies costeiras, bacias glaciais basculadas e com } \\
\text { declive forte. } \\
\text { - lados de vales jovens, em lagos ou mares fechados e em escarpas de falha. }\end{array}$ & $\begin{array}{l}\text { - declive regional pronunciado (longo) e inclinação moderada a forte. } \\
\text { - controle do declive por feições topográficas paralelas, controladas } \\
\text { por estruturas dobradas, falhadas ou estruturas monoclinais. }\end{array}$ \\
\hline Retangular & $\begin{array}{l}\text { - curvas em ângulo reto tanto no canal principal como nos tributários, } \\
\text { sendo mais irregular que o padrão treliça. } \\
\text { - confluências em ângulo reto. }\end{array}$ & $\begin{array}{l}\text { - controle estrutural dominante. } \\
\text { - juntas e falhas das rochas em ângulo reto. } \\
\text { - os canais seguem linhas de fraqueza. } \\
\text { - rochas metamórficas e sedimentares dobradas. }\end{array}$ \\
\hline Centrífugo & $\begin{array}{l}\text { - os canais se irradiam de uma área central. } \\
\text { - radial do centro para fora. } \\
\text { - multiradial é um complexo de padrões radiais em um campo vulcânico. }\end{array}$ & $\begin{array}{l}\text { - drenagem conseqüente de domos, montanhas (vulcões, maciços } \\
\text { residuais). }\end{array}$ \\
\hline Anelar & $\begin{array}{l}\text { - é como um anel. } \\
\text { - subseqüente em origem, associado com domos dissecados ou estruturas } \\
\text { em bacias. } \\
\text { - conseqüente e radial em origem. } \\
\text { - tributários subseqüentes desenvolvidos na medida em que a erosão avança. } \\
\text { - desenvolve-se quando os estratos sedimentares apresentam grandes } \\
\text { variações no grau de resistência. }\end{array}$ & $\begin{array}{l}\text { - maior influência da estrutura sobre o declive. } \\
\text { - o declive só controla o curso inicial do canal. } \\
\text { - estrutura e declive ajustam o curso da maturidade do canal. }\end{array}$ \\
\hline Multibacinal & $\begin{array}{l}\text { - múltiplas depressões. } \\
\text { - lagos. }\end{array}$ & $\begin{array}{l}\text { - depósitos superficiais com forma em hummocky. } \\
\text { - áreas de vulcanismo recente, dissolução de calcários e permafrost. }\end{array}$ \\
\hline Contorcido & $\begin{array}{l}\text { - o padrão difere do treliça recurvado pela carência de uma linha de ordem } \\
\text { regional, e a descontinuidade de cristais e vales geralmente é em menor } \\
\text { escala. }\end{array}$ & $\begin{array}{l}\text { - rochas metamórficas grosseiramente acomodadas. } \\
\text { - diques, veios e bandas migmatizadas dão origem a camadas } \\
\text { resistentes em algumas áreas. }\end{array}$ \\
\hline
\end{tabular}


Tabela 2 - Padrões de drenagem modificados e seus significados. (modificada de Howard, 1967).

\begin{tabular}{|c|c|c|}
\hline \multicolumn{3}{|c|}{ TIPOS MODIFICADOS DE PADRÕES DE DRENAGEM } \\
\hline \multirow{2}{*}{\multicolumn{3}{|c|}{ DENDRITICO MODIFICADO }} \\
\hline & & \\
\hline Subdentrítico & $\begin{array}{l}\text { - canais principais conseqüentes com tributários se estendendo horizontalmente. } \\
\text { - variações sutis do dendrítico. }\end{array}$ & $\begin{array}{l}\text { - fraco controle topográfico ou estrutural tênue e controle secundário } \\
\text { insignificante } \\
\text { - rochas homogêneas. }\end{array}$ \\
\hline Pinado & $\begin{array}{l}\text { - os canais são conseqüentes em origem. } \\
\text { - junções em ângulo agudo e tributários freqüentemente espaçados e mais ou menos } \\
\text { paralelos. } \\
\text { - padrão em forma de pena ou como copa de árvores. }\end{array}$ & $\begin{array}{l}\text { - controle pela declividade uniforme do canal principal. } \\
\text { - rochas homogêneas resistentes (materiais facilmente erodíveis de } \\
\text { textura fina como cinzas vulcânicas e siltes). }\end{array}$ \\
\hline Dicotômico & - padrão arborescente ou em ramagens. & - a acumulação recente é o fator controlador. \\
\hline Distributário & - leques aluviais e deltas com tributários divergindo de um canal principal. & \\
\hline Anastomótico & $\begin{array}{l}\text { - entrelaçamento de canais tortuosos, lamacentos, pantanosos. } \\
\text { - comuns em planícies de inundação, deltas e pântanos de maré. }\end{array}$ & \\
\hline \multicolumn{3}{|c|}{ TRELIÇA MODIFICADO } \\
\hline Subtreliça & - formas de relevo alongadas e paralelas e continuidade de drenagem dominante. & \\
\hline $\begin{array}{c}\text { Treliça } \\
\text { direcional }\end{array}$ & $\begin{array}{l}\text { - direção de treliça dominante controlada pela estrutura ou pela litologia - tributários } \\
\text { em um lado mais longos que no outro. }\end{array}$ & $\begin{array}{l}\text { - série de falhas, juntas ou planos de fraqueza paralelas. } \\
\text { - declividade fraca com cristas de praia ou homoclíneo suave. }\end{array}$ \\
\hline Treliça falha & $\begin{array}{l}\text { - o espaçamento entre os canais subseqüentes paralelo é mais largo que no treliça } \\
\text { típico. } \\
\text { - ramos convergentes e divergentes, de falhas paralelas. }\end{array}$ & $\begin{array}{l}\text { - é um treliça controlado por falhas ou planos de fraqueza paralelos. } \\
\text { - grabens e horsts alternados ou uma sucessão de rifts paralelos. }\end{array}$ \\
\hline Treliça junta & - falhas e/ou juntas retilíneas e paralelas. & \\
\hline $\begin{array}{l}\text { Treliça } \\
\text { recurvado }\end{array}$ & - curvas acentuadas ao redor de narizes de dobras com caimento. & $\begin{array}{l}\text { - distinção entre antiformes e sinformes, o canal mais longo indica a } \\
\text { direção do mergulho do eixo. }\end{array}$ \\
\hline Reticulado & - como um grid. & - origem natural e antropogênica. \\
\hline \multicolumn{3}{|c|}{ PARALELO MODIFICADO } \\
\hline Subparalelo & $\begin{array}{l}\text { - canais orientados em direções similares mas sem a regularidade do padrão paralelo } \\
\text { - como uma árvore de álamo. }\end{array}$ & $\begin{array}{l}\text { - xistosidade, falhamentos e dobramentos complexos. } \\
\text { - controle pela declividade e formas de relevo paralelas. }\end{array}$ \\
\hline Colinear & $\begin{array}{l}\text { - sucessão de canais que se estendem ao longo de uma mesma linha reta (podem } \\
\text { desaparecer e emergir abaixo). }\end{array}$ & $\begin{array}{l}\text { - litologia. Dunas ou sulco em rochas de composição uniforme (areias, } \\
\text { poeira vulcânica). }\end{array}$ \\
\hline \multicolumn{3}{|c|}{ RELANGULAR MODIFICADO } \\
\hline Angular & $\begin{array}{l}\text { - as junções formam ângulos agudos ou obtusos sem nenhum ângulo reto. } \\
\text { - curvas em ângulo agudo e tributário com curso contrário ao gradiente do vale. }\end{array}$ & $\begin{array}{l}\text { - rochas ígneas ou metamórficas intensamente falhadas } \\
\text { - intercessão de sistemas de falhas e juntas nem sempre em ângulo } \\
\text { reto. }\end{array}$ \\
\hline \multicolumn{3}{|c|}{ CENTRIFIUGO MODIFICADO } \\
\hline Centrípeto & $\begin{array}{l}\text { - vertentes internas de crateras ou caldeiras, domos brechados, bacias estruturais. } \\
\text { - algumas vezes suas dimensões são insignificantes para aparecer nos mapas. } \\
\text { - os canais fluem para dentro, ou nas proximidades de depressões centrais fechadas. }\end{array}$ & $\begin{array}{l}\text { - a drenagem centrípeta de bacias estruturais pode ser conseqüente ou } \\
\text { reseqüentes, enquanto que nos domos é obseqüente. } \\
\text { - crateras, caldeiras ou outras depressões, sinclinais ou anticlinais } \\
\text { erodidos. }\end{array}$ \\
\hline
\end{tabular}


Os vários tipos padrões de drenagem estão geralmente ligados à topografia, posicionamento de rochas e situações intempéricas (Bloom, 1991; Kehew, 1995; Bezerra, 2003). Como apresentado nas tabelas 1 e 2, muitos dos padrões de drenagem denotam anomalias que auxiliam no reconhecimento de áreas com controle tectônico, o que também é sugerido por mudanças súbitas entre esses padrões. Além disto, existe uma variedade de outras anomalias de drenagem que sugerem a presença de estruturas tectônicas. Dentre estas, destacam-se como as mais importantes: retilinearidade de canais, mudanças abruptas de cursos, por vezes formando feições ortogonais ou em "cotovelo", aparecimento abrupto e localizado de meandros, meandros comprimidos, desenvolvimento abrupto e localizado de canal anastomótico, estreitamento ou alargamento súbito de vales ou canais, diques marginais isolados, aparecimento brusco de canal do tipo entrelaçado e entrelaçamento localizado de drenagem associada com canais abandonados, curvas anômalas, ausência de divisor de águas com desenvolvimento de lagos e grande incidência de terraços (Holmes, 1965; Howard, 1967; Deffontaines \& Chorowicz, 1991; Berger, 1994) (Figura 6). 


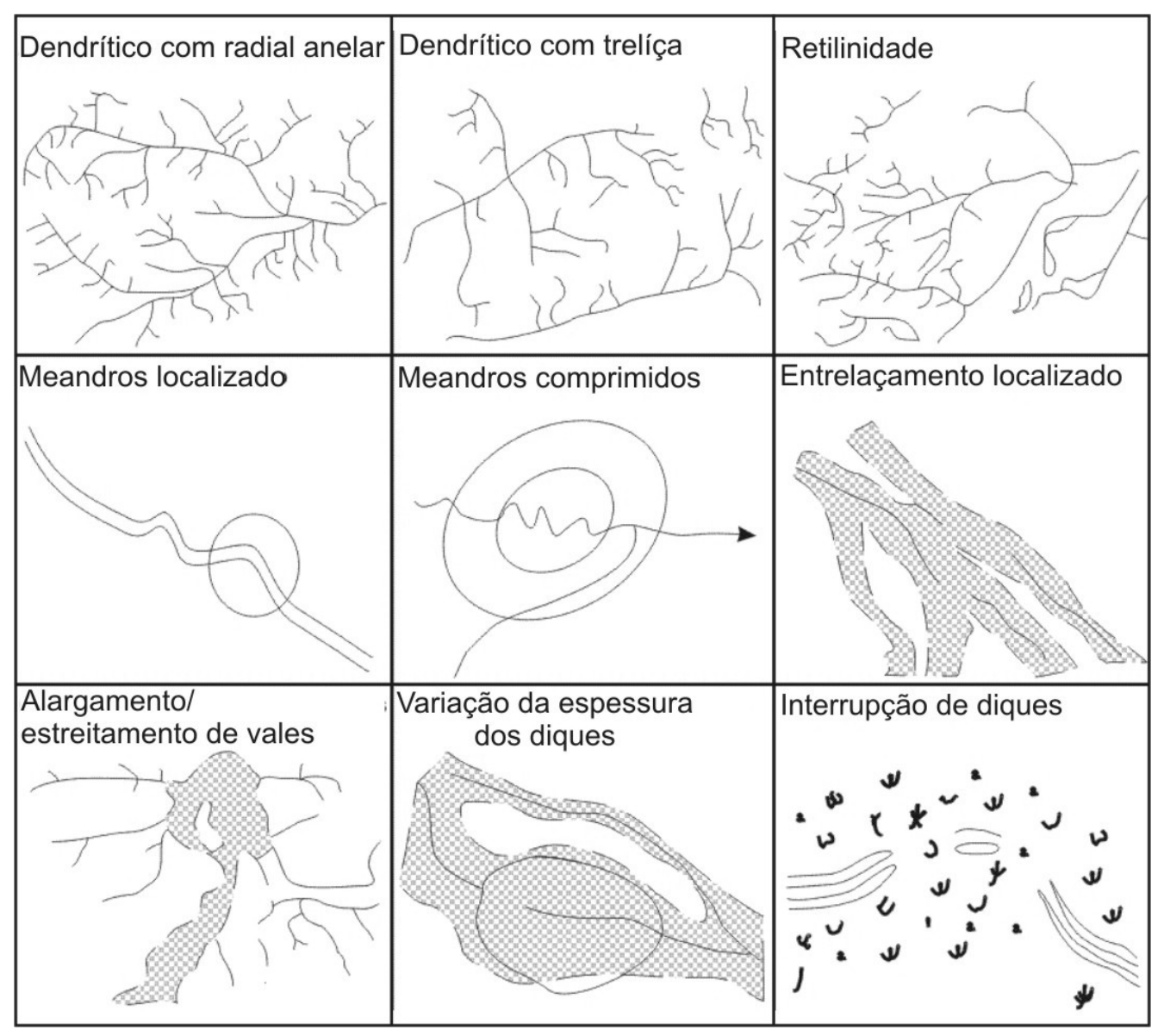

Figura 6 - Anomalias de drenagem. (modificada de Howard, 1967).

Os canais são formados a partir da disposição espacial da drenagem, cuja morfologia dos rios implica no tipo de descarga grau de estabilidade e forma do canal. De acordo com este parâmetro, os rios podem ser retilíneos, meândricos, anastomóticos ou entrelaçados (Figura 7). Canais retilíneos são raros e ocorrem em trechos curtos. Possuem sinuosidade extremamente baixa, elevada estabilidade e domínio de carga de suspensão ou mista. Rios s meândricos são altamente sinuosos, de estabilidade alta a média, em geral com domínio de carga mista. Rios anastomóticos são estáveis, ligeiramente sinuosos, que contornam ilhas vegetadas. Rios entrelaçados mostram sinuosidade e estabilidade baixas e com domínio de 
carga de fundo. Esses tipos podem ocorrer de forma isolada ou conjunta dentro de uma mesma bacia de drenagem, dependendo da evolução do seu sistema fluvial em virtude das variações temporais da drenagem. Portanto, uma zona do rio pode ser anastomosada em períodos de estiagem (sem chuva) e meandrante em épocas de cheia (Cunha, 1994).

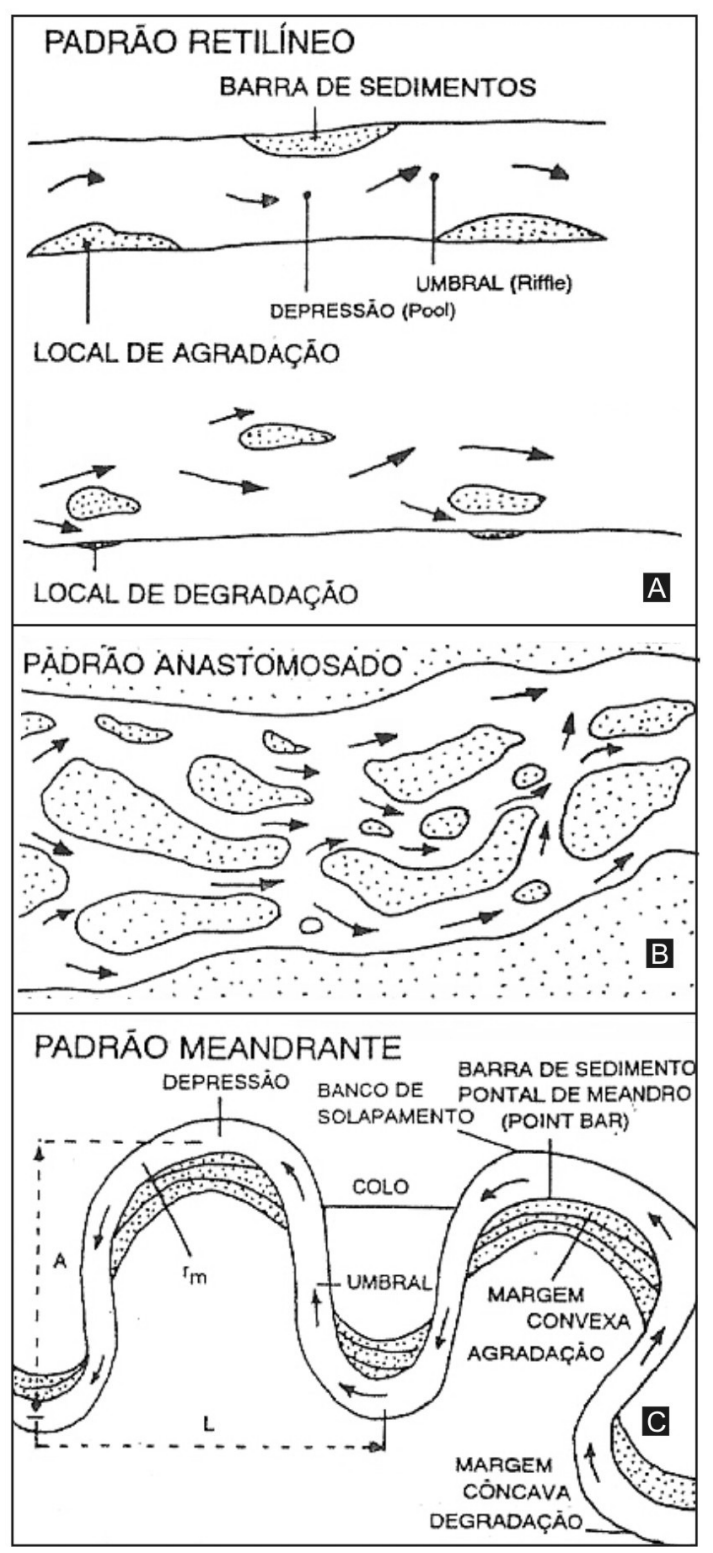

Figura 7 - Padrões de canais. A. Retilíneo. B. Anastomosado. C. Meandrante: (L) comprimento do meandro e $(\mathrm{Rc})$ raio médio da curvatura do meando. (modificada de Cunha, 1994). 


\subsection{Lineamento morfoestrutural e Sensoriamento Remoto (SR)}

Lineamento morfoestrutural corresponde à expressão espacial de feições morfológicas da paisagem que possam ter relação com feições geológicas, podendo revelar seu comportamento tectônico. Esses lineamentos são, em geral, expressos por (Hobbs, 1904, 1912): 1) cristas de cordilheiras ou limites de áreas elevadas; 2) linhas de drenagem; 3) linhas de costa; e 4) linhas representativas de contatos litológicos. Com o avanço das pesquisas geológicas e, principalmente, com a tecnologia de obtenção de dados geofísicos, o termo lineamento recebeu definição mais abrangente, caracterizando feições lineares de âmbito regional que se expressam na topografia pela morfologia de vales, cristas, segmentos de drenagem e anomalias tonais, controladas estruturalmente por foliações, juntas/fraturas e falhas (O’Leary et al. 1976; Sabins, 1978).

O reconhecimento de lineamentos morfoestruturais é feito com base na identificação de feições retilíneas na paisagem, que correspondem ao alinhamento de cristas e vales (O’Leary et al. 1976). Particularmente em terrenos onde exposições de rocha são raras, este tipo de informação morfológica, juntamente com anomalias de drenagem, pode constituir o único elemento identificável na paisagem a sugerir a ocorrência de estruturas tectônicas em subsuperfície. Isto ocorre porque lineamentos morfoestruturais têm boa equivalência com estruturas tectônicas, tais como falhas e fraturas (p.e., Schumm, 1981; Ouchi, 1985; Schumm, 1986; Keller \& Pinter, 1996; Holbrook \& Schumm, 1999; Delcaillau et al. 2006; Ecthebehere et al. 2006; Peter \& Balen, 2007; Shtober-Zisu et al. 2008). Para o caso da região amazônica e, em especial para a ilha do Marajó, onde o relevo é praticamente insignificante, lineamentos morfoestruturais podem ser baseados apenas no reconhecimento 
de segmentos retilíneos de drenagem, os quais puderam ser extraídos da análise de mapas de drenagem disponíveis, aprimorados pela análise de dados de sensoriamento remoto.

Para o caso do presente estudo no leste da ilha do Marajó, escolheu-se utilizar imagens Landsat, uma vez que se identificou que o arquivo de imagens disponível contém imagens contendo poucas nuvens e, ao contrário das demais áreas amazônicas, a porção leste da ilha apresenta predomínio de vegetação de savana e/ou solo exposto, o que favorece a análise morfológica. Além disto, deu-se preferência ao uso de imagens Landsat porque outros tipos de produtos de sensoriamento remoto de fácil acesso ou contém ruídos devido à topografia exageradamente baixa (p.e., MDE-SRTM), ou são de resolução inferior (p.e., dados de radar de abertura sintética do Japanese Earth Resource Satellite-JERS-1).

O primeiro satélite da série Landsat (Land Observation Satellite) foi lançado no início dos anos 70, sendo que atualmente estão em operação o quinto e o sétimo da série. Esta série de satélites é a principal no campo do sensoriamento remoto, não só por ser a de período de vida mais longo de fornecimento contínuo de dados, mas também pela notável facilidade de acesso e qualidade dos dados gerados.

Das séries Landsat lançados, os Landsat-5 e 7 são de particular interesse em estudos morfológicos e vegetacionais, por possuírem a bordo o sensor TM (Thematic Mapper). Este sensor imageador óptico é capaz de adquirir imagens em sete bandas espectrais, das quais três compreendem a região do visível do espectro eletromagnético, uma região do infravermelho próximo, duas na região do infravermelho médio e uma na região do termal. Com faixa (swath) de imageamento de $185 \mathrm{~km}$, o Landsat-5 apresenta resolução espacial do de $30 \mathrm{~m}$ x $30 \mathrm{~m}$ para as bandas que operam nas regiões do visível e infravermelho refletido e de $120 \mathrm{~m}$ x $120 \mathrm{~m}$, para a região do termal. O satélite Landsat-7 possui o sensor 
ETM+ (Enhanced Thematic Mapper Plus) que, além das bandas do Landsat-5, apresenta uma banda pancromática com resolução espacial de $15 \mathrm{~m}$ e uma banda termal com resolução espacial aumentada para $60 \mathrm{~m}$, ao invés de $120 \mathrm{~m}$ presente no sensor do Landsat5.

Estudos prévios fizeram uso de dados orbitais para a caracterização de lineamentos morfoestruturais em outras áreas amazônicas (p.e., Souza Filho \& El Robrini, 2000; Souza Filho, 2000; Silva, 2005; Rozo et al. 2005; Souza Filho et al. 2006; Paradella et al. 2000a, b, 2003; França \& Souza Filho, 2003). Além disto, esforços anteriores já utilizaram produtos de sensoriamento remoto na caracterização morfoestrutural na ilha do Marajó (i.e., Bermerguy et al. 2003; Rossetti \& Valeriano, 2007; Mantelli, 2008; Rossetti et al. 2008b; Mantelli \& Rossetti 2009).

\subsection{Radar de Penetração no Solo}

O GPR é um equipamento robusto, portátil e de fácil utilização, que se baseia na coleta de dados de subsuperfície rasa (i.e., em geral até $50 \mathrm{~m}$ ) pela emissão de ondas eletromagnéticas de alta freqüência (normalmente de 10-1.000 MHz). Este equipamento consiste geralmente dos seguintes componentes: unidade de controle de radar, antenas transmissora e receptora; dispositivos armazenador e/ou amostrador, conversor de corrente e amplificador (Figura 8A). Os componentes são digitalmente controlados, e os dados são registrados através do processamento e amostragem feitos por levantamento.

Sua operação consiste na emissão de um pulso eletromagnético gerado pela unidade de controle numa determinada intensidade e faixa de freqüência. Este pulso, irradiado por antena transmissora, viaja através do material em velocidade determinada principalmente 
pelas propriedades elétricas dos materiais constituintes. As reflexões são registradas na unidade receptora, sendo dependentes do contraste entre essas propriedades (basicamente analisado em termos das diferenças em relação à constante dielétrica (k), que em última análise depende da condutividade elétrica e permeabilidade magnética da interface do material) (Figura 8B).

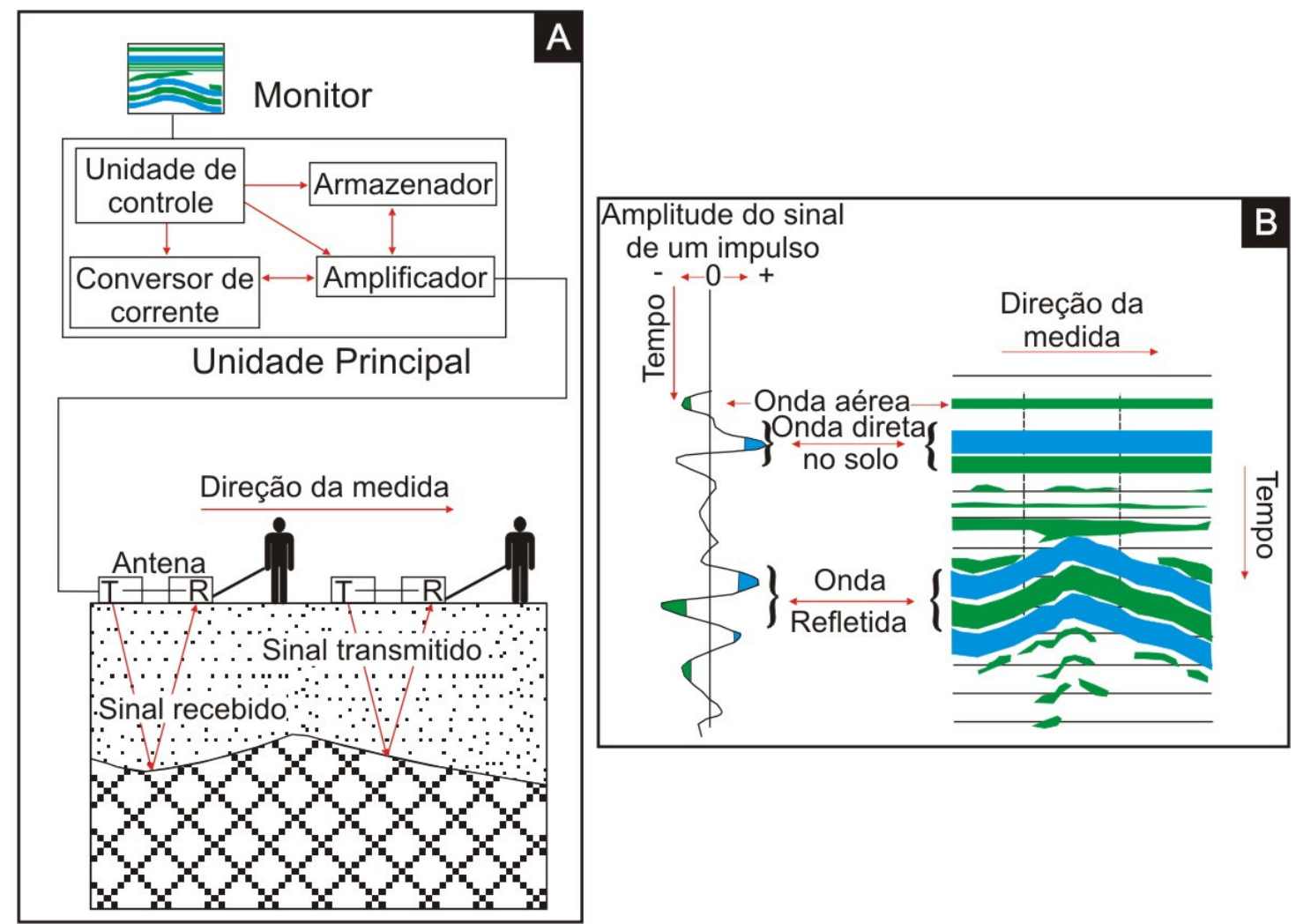

Figura 8 - Quadro ilustrativo da aquisição de dados de GPR e perfil resultante. (A)

Levantamento para aquisição de dados de GPR, mostrando os componentes do sistema e a configuração do refletor de subsuperfície. (B) Perfil de reflexão resultante e seus eventos sísmicos.

A propagação do pulso de EM em subsuperfície é influenciada pela heterogeneidade nas seguintes propriedades eletromagnéticas do meio: (a) a permissividade dielétrica, onde 
a relação entre as permissividades de duas camadas distintas definirá o coeficiente de reflexão (Beres \& Haeni, 1991); (b) a susceptibilidade magnética; e (c) a condutividade elétrica que, junto à frequiência do sinal emitido, determinam a profundidade de penetração em subsuperfície (Dagallier et al. 2000).

Na medida em que a energia eletromagética se dispersa e viaja em subsuperfície, pode haver colisão com algum objeto soterrado ou mesmo limitar-se às diferentes propriedades elétricas do material. Então, parte desta energia é refletida ou dispersada de volta à superfície, enquanto que a outra parte continua viajando em subsuperfície (McMechan et al. 1997).

O GPR tem sido utilizado em inúmeras aplicações: a. hidrogeológicas (Beres \& Haeni, 1991; Rea \& Knight, 1995; Greaves et al. 1996; Nakashima et al. 2001; Marcelino et al. 2005); b. arqueológicas (Vaughan, 1986; Cezar et al. 2001); c. em estudos de engenharia (Dourado et al. 2003); e d. na pesquisa de depósitos minerais (Porsani et al. 2004). Em tempos mais recentes, o GPR tem-se destacado pela sua grande aplicabilidade na caracterização faciológica, no mapeamento estratigráfico de sucessões sedimentares de diferentes idades geológicas e no delineamento de estruturas tectônicas (p.e., Jol \& Smith, 1991; Knoll et al. 1991; Gawthorpe et al. 1993; Dominic et al. 1995; Bristow, 1995 a, b; Van Heteren et al. 1998; Ellefsen, 1999; Uchua et al. 1999; Dagallier et al. 2000; Silva \& Scherer, 2000; Basson et al. 2002; Rashed et al. 2003; Neal, 2004; Castro et al. 2005; Maurya et al. 2005; Patidar et al. 2008).

No Brasil muito trabalhos aplicando o GPR no campo da sedimentológicos/estratigráficos têm demonstrado que este método fornece subsídios importantes para a reconstituição da dinâmica eólica recente, preservada em depósitos eolianitos pouco comum no litoral do Brasil e importante marcador das condições 
climáticas e geoambientais pretéritas, bem como, em distinção de canais turbidíticos e de estruturas rúpteis em depósitos neógenos no nordeste e sudeste brasileiro (p.e., Porsani, 1999; Dourado et al. 2001; Pereira, 2001; Borges \& Porsani, 2002; Pereira et al. 2003; Ceia et al. 2004; Nogueira, 2004; Nogueira et al. 2006; Moura et al. 2005; Souza et al. 2005).O uso do GPR na Amazônia tornou-se importante para desvendar a complexidade de sedimentação versus erosão durante o Neógeno no norte do Brasil, implicando no mapeamento de superfícies estratigráficas chaves distinguidas sob depósitos da Formação Barreiras e sua relação à queda do nível do mar relativo, e por sua o deslocamento destas superfícies associadas a zonas de transcorrência (p.e., Rossetti, 2001 e 2003; Rossetti \& Góes, 2001, ), além de análises destas características na Formação Alter do Chão, Estado do Amazonas, (Silva, 2005).

\subsection{Sondagem Elétrica Vertical}

A propriedade elétrica mais importante e significativa em subsuperfície é a resistividade, que é inversamente proporcional à condutividade elétrica. A resistividade é considerada como a resistência dos materiais em conduzir a corrente elétrica. A resistividade de solos e rochas é afetada principalmente pela: composição mineralógica; porosidade; teor em água; e quantidade e natureza dos sais dissolvidos. Dentre esses fatores, os mais importantes são, sem dúvida, a quantidade de água e a salinidade. O aumento do teor de umidade e da quantidade de sais dissolvidos leva a uma diminuição dos valores de resistividade. Outras propriedades também importantes, mas de menor relevância, são a permeabilidade magnética (fator de influência indireta) e a constante dielétrica das rochas e dos minerais (Telford et al. 1990). 
O ensaio eletrorresistivo de prospecção superficial baseia-se no cálculo da resistividade aparente, consistindo em injetar corrente contínua ou de baixa freqüência em dois pontos do terreno (A e B) para medir a diferença de potencial entre dois outros pontos (M e N) (Figura 9).

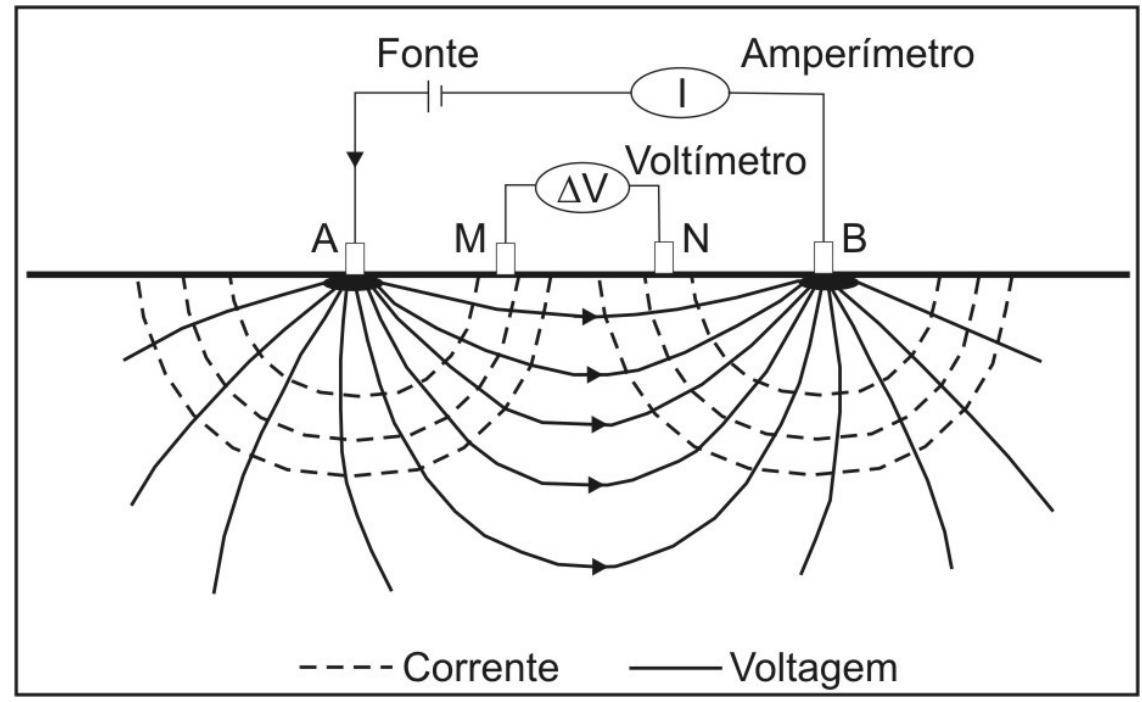

Figura 9 - Disposição dos eletrodos na superfície do terreno e fluxo de corrente. (modificada de Freitas Filho, 2006).

A equação para o cálculo da resistividade é dada seguindo a Lei de Ohm, considerando o fluxo de uma corrente contínua ou alternada de muito baixa freqüência, desprezando-se o deslocamento da corrente em um meio homogêneo, ilimitado e isotrópico. Sendo assim, temos:

$$
\vec{J}=\sigma \cdot \overrightarrow{\mathrm{E}}
$$

Sendo: $\vec{J}$ - densidade de corrente (em $\left.\mathrm{A} / \mathrm{m}^{2}\right) ; \sigma$ - condutividade (em $\mathrm{S} / \mathrm{m}$ ), que é definida pelo inverso da resistividade (i.e., $\sigma=1 / \rho$ e e $\vec{E}$ - campo elétrico (em V/m).

Partindo desta lei, com a substituição das relações: 


$$
\vec{J}=\frac{I}{A} ; \sigma=\frac{1}{\rho} ; \vec{E} \approx \frac{\Delta V}{l} \Rightarrow \frac{I}{A} \approx \frac{1}{\rho} \frac{\Delta V}{l} \Rightarrow \rho=\frac{A}{l}\left(\frac{\Delta V}{I}\right)=k\left(\frac{\Delta V}{I}\right)
$$

Onde: $l$ - espaçamentos dos eletrodos de potencial; $A$ - área transversal.

Obtém-se a resistividade elétrica do semi-espaço homogêneo.

$$
\rho=\mathrm{k} \cdot\left(\frac{\Delta \mathrm{V}}{\mathrm{I}}\right)
$$

Sendo: $\mathrm{k}$ - fator geométrico que depende do arranjo dos eletrodos na superfície; $\Delta \mathrm{V}-$ diferença de potencial elétrico entre os eletrodos de potencial "M e N"; e I - corrente contínua aplicada entre os eletrodos de corrente "A e B".

Em que o fator geométrico " $k$ " é dado por:

$$
k=2 \pi \cdot\left(\frac{1}{\frac{1}{\mathrm{AM}}-\frac{1}{\mathrm{BM}}-\frac{1}{\mathrm{AN}}+\frac{1}{\mathrm{BN}}}\right)
$$

No entanto, a equação (2) é válida somente para meios homogêneos, o que não acontece com o subsolo, pois este é constituído por $n$-camadas de $n$-resistividades e $n$ espessuras. Sendo assim, a resistividade medida é chamada de resistividade aparente $\left(\rho_{\mathrm{a}}\right)$, que não é propriamente a resistividade média, e sim um parâmetro experimental. Esta expressa os resultados das medições (Orellana, 1972), e depende do espaçamento entre os eletrodos (p.e., AB/2 ou L) e das espessuras e resistividades verdadeiras do pacote rochoso da área em estudo. Portanto, a $\rho_{\mathrm{a}}$, é numericamente obtida utilizando-se a equação (2), sendo posteriormente estimada utilizando processos de inversão.

De acordo com o posicionamento dos eletrodos em superfície, é possível realizar três tipos de sondagens elétricas: vertical (SEV), radial (SEVR) e caminhamento elétrico (CE), 
A técnica de SEV foi aplicada neste trabalho, em virtude da sua maior facilidade de operação. Dentre a SEV, há diversos tipos de dispositivos ou arranjos de eletrodos (p.e., Schlumberger, Lee e Wenner), sendo o arranjo Schlumberger o aplicado no presente trabalho, devido à praticidade no manuseio em terrenos sedimentares. A geometria do arranjo Schlumberger configura um quadripolo (AMNB). Este, por sua vez, é alinhado com o centro "0" de $\mathrm{AB}$, coincidindo com o ponto intermediário entre os eletrodos $\mathrm{M} \mathrm{e} \mathrm{N}$, tendo como característica principal o fato da distância $\mathrm{MN}$ ser pequena em relação à distância $\mathrm{AB}$ (MN $<<\mathrm{AB}$ ) (Figura 10). Logo, o fator geométrico "k" é calculado a partir da equação (3):

$$
k=\pi\left(\frac{L^{2}}{b}-\frac{b}{4}\right) \quad \text { ou } \quad k=\pi\left(\mathrm{L}^{2}-\frac{\mathrm{b}^{2}}{4}\right) \cdot \frac{1}{\mathrm{~b}}
$$

Onde: $b=\mathrm{MN}$ e $L=\frac{A B}{2}$.

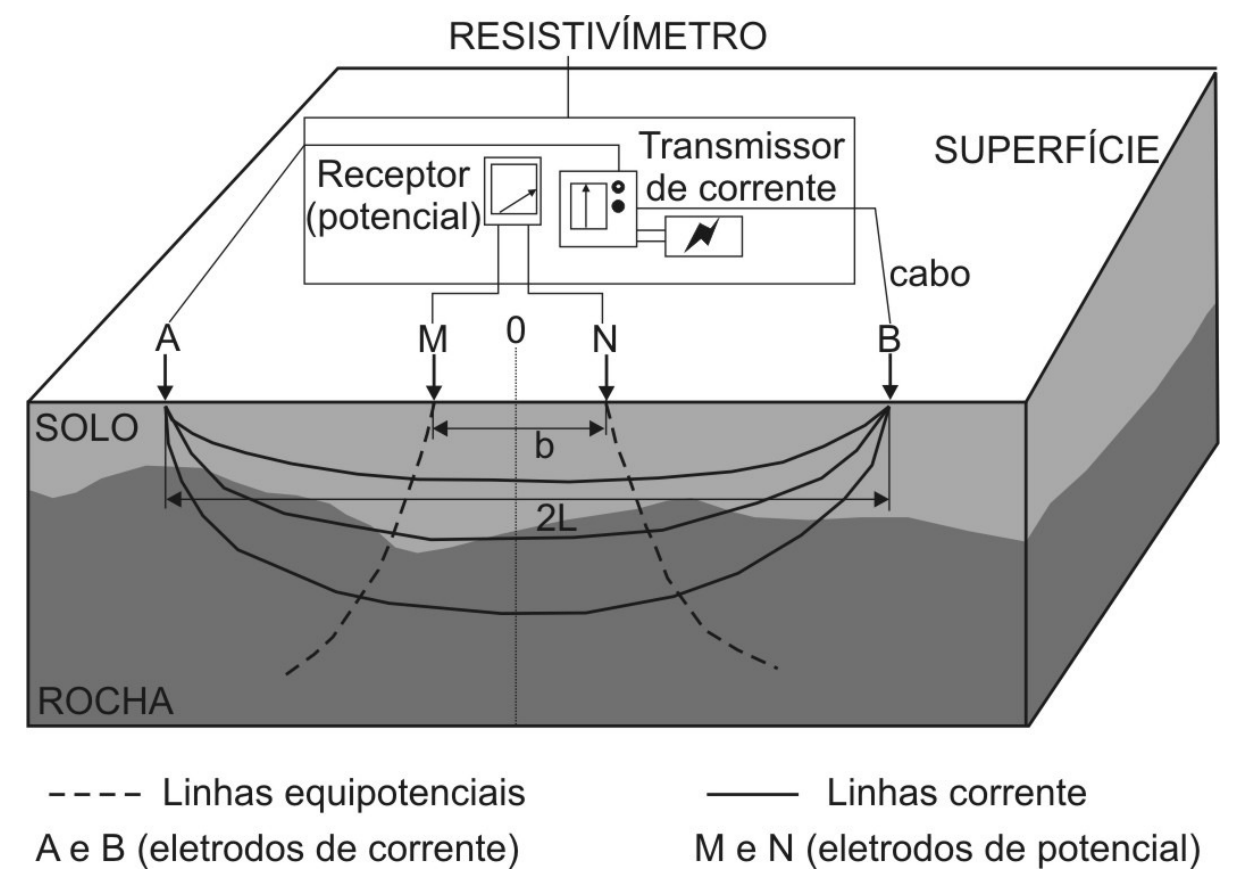

Figura 10 - Quadripolo AMNB (dispositivo Schlumberger). (modificada de Souza, 2005). 
Da mesma forma que o GPR, a SEV também é bastante usada em diversos campos: hidrogeologia, mapeamento de estruturas geológicas e no meio ambiente. No Brasil é amplamente usada em terrenos sedimentares para distinção de lençol freático e locação de poços, e possíveis plumas de contaminação (p.e., Porsani, 1981; Mendes \& Verma, 2002; Bahia, 2003; Nunes, 2005; Souza \& Verma, 2005; Freitas Filho, 2006; Olívia \& Kiang, 2007; Costa \& Malagutii Filho, 2008). Num contexto mundial este método tem incessante aplicação no mapeamento e delineamento de corpos geológicos e feições tectônicas em zonas de tectônica extensional a fim de demonstrar movimentos tectônicos recentes e seu efeito em terremotos fortes (p.e., Jie et al. 2002; Özürlan et al. 2006).

\section{LEVANTAMENTOS GEOFÍSICOS NA ILHA DO MARAJÓ}

Estudos geofísicos prévios na ilha do Marajó incluem aplicação das técnicas de SEV, sísmica de refração rasa, método eletromagnético e potencial espontâneo. Com exceção da SEV, as demais técnicas foram utilizadas em caráter experimental e em escala reduzida. A sísmica de refração não mostrou resultados positivos (Guimarães, 1983). Já o método eletromagnético foi utilizado para o reconhecimento lateral de zonas de água doce-água salobra (Guimarães, 1983; Verma \& Bischoff, 1989). Por outro lado, a SEV tem sido de larga aplicação desde o início dos anos setenta, visando-se a prospecção de água subterrânea, tendo-se em vista sua boa resposta nesse campo e baixo custo operacional (Trancredi, 1972; Carrasquila et al. 1991; IDESP, 1974 e 1986; Bezerra, 1979; Cavalcanti, 1979; Kobayashi, 1979; Porsani, 1981; Gonzáles, 1984). 
Um total de 694 SEV (IDESP, 1974 e 1986) foi realizado na porção oriental da ilha do Marajó, perfazendo um total de $16.325 \mathrm{~km}^{2}$, com malha aproximada de 4 a $5 \mathrm{~km} \mathrm{de}$ espaçamento e profundidade máxima de investigação de $100 \mathrm{~m}$. Estas sondagens evidenciaram grande diversidade nos valores da resistividade (IDESP, 1986), que variam de $1 \Omega \mathrm{m}$ até vários milhares de ohms, e estas, por sua vez, podem ser classificadas em três tipos principais: tipo A - horizonte resistivo em superfície e a pequena profundidade, seguido por um horizonte condutor; tipo B - horizonte condutor até o substrato resistivo; e tipo C - horizonte condutor em superfície recobrindo um nível resistivo, ao qual segue um horizonte condutor (Figura 11). Ressalta-se, ainda, que, com linhas AB muito extensas em toda a ilha, detectou-se um substrato resistivo a grande profundidade, na ordem de $100 \mathrm{~m}$ (IDESP, 1986).

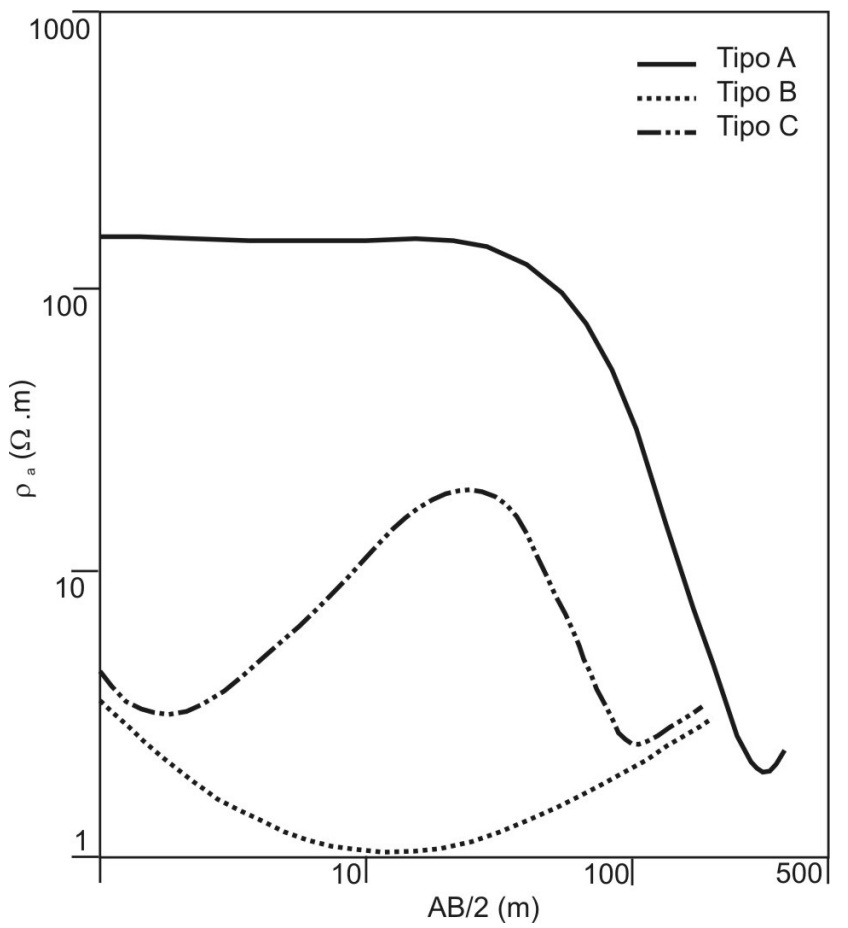

Figura 11 - Sondagem Elétrica Vertical Tipo da ilha do Marajó. (modificada de IDESP, 1986). 
A interpretação quantitativa das 694 SEV utilizando mapas e perfis de resistividade aparente $\left(\rho_{\mathrm{a}}\right)$ (Trancredi, 1972; IDESP, 1986) levaram aos seguintes resultados: (a) a $1 \mathrm{~m}$ de profundidade a pa é superior a $1.000 \Omega \mathrm{m}$, marcando bem o leste da ilha até as regiões de Cachoeira do Arari, Ponta de Pedras e Muaná, conseqüentemente, a porção norte é a mais condutiva com valores inferiores a $100 \Omega \mathrm{m}$; (b) a partir de $20 \mathrm{~m}$ de profundidade a parte norte no centro da ilha a $\rho_{\mathrm{a}}$ é muito fraca $(<3 \Omega \mathrm{m})$. Já na parte sul, sudeste e leste (área de Salvaterra) este valor é superior a $300 \Omega \mathrm{m}$; e (c) em torno de 100-200 m de profundidade valores $\rho_{\mathrm{a}}$ são raramente superiores a $100 \Omega \mathrm{m}$, configurando-se assim, a presença de um complexo condutivo em profundidade (Figuras 12 e 13). Portanto, as áreas mais resistivas situam-se na parte sul e sudeste da região dos campos naturais, com valores de $\rho_{a}$ superiores a $1.000 \Omega \mathrm{m}$. Na área central (próximo ao lago Arari), a $\rho_{\mathrm{a}}$ tem valores de alguns ohms a algumas dezenas de ohms. Esses resultados indicam a grande extensão dos solos argilosos. Na parte sul e sudeste, há um aumento da fração areno-argilosa (Trancredi, 1972; IDESP, 1986).

Carrasquila et al. (1991), ao reinterpretar dados de 800 SEV feitas na ilha, realizadas pelo Núcleo de Geofísica da Universidade Federal do Pará, em escala regional entre os anos de 70 e 80, corroboraram a existência das três famílias de SEV descritas por IDESP (1986). Estes autores mostraram, ainda, que os mapas de resistividade também confirmaram resistividades variando de 40 a $1.500 \Omega \mathrm{m}$ nas zonas sul e sudeste. Essa variação foi associada à presença de arenitos ferruginosos e salobros próximos à superfície, e calcário a profundidades superiores a $30 \mathrm{~m}$. A zona noroeste é medianamente resistiva (de até $30 \Omega \mathrm{m}$ ) com profundidades de $100 \mathrm{~m}$, como reflexo da presença de planícies colmatadas por sedimentos holocenos (sedimentos argilosos e arenosos salinizados). A 
zona central e norte é altamente condutiva (10 a $100 \Omega \mathrm{m})$, o que foi associado às camadas argilosa ou arenosa com água salgada a profundidades inferiores a $100 \mathrm{~m}$.
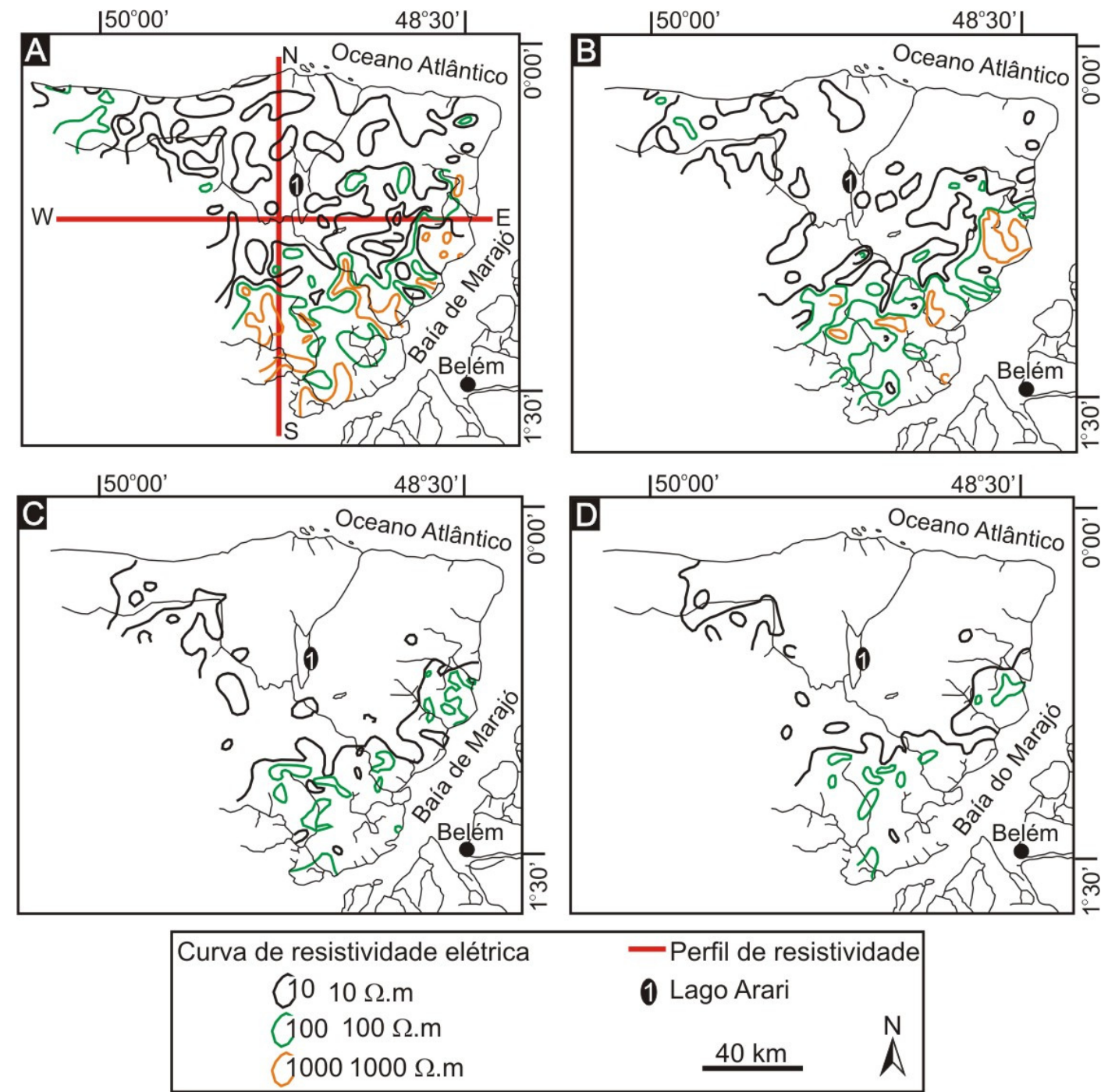

Figura 12 - Mapas de resistividades na porção oriental da ilha do Marajó. (A) linha $A B=2$ m. (B) linha $\mathrm{AB}=40 \mathrm{~m}$. (C) linha $\mathrm{AB}=300 \mathrm{~m}$. (D) linha $\mathrm{AB}=400 \mathrm{~m}$ de profundidade. (modificada de Trancredi, 1972; IDESP, 1986). 

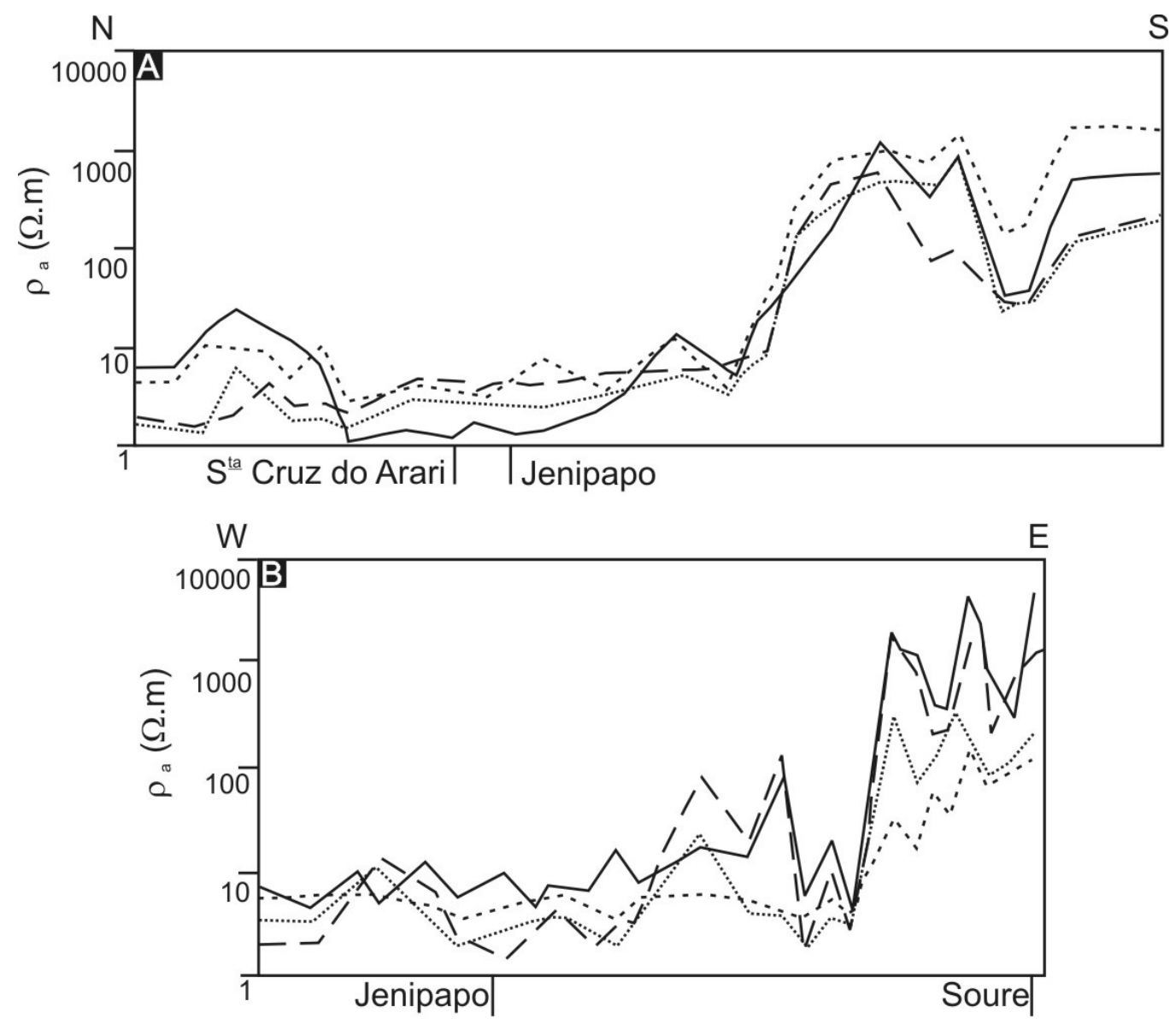

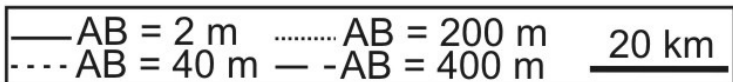

Figura 13 - Perfis de resistividades em linhas AB de 2 m, 40 m, 200 m e 400 m de profundidade da parte oriental da ilha do Marajó. (A) N-S. (B) W-E. Estes perfis estão posicionados na Figura 12A. (modificada de Tancredi, 1972; IDESP, 1986).

Contrastando trabalhos anteriores (i.e., IDESP, 1974, 1986; Trancredi, 1972), que apontaram como sendo da ordem de $1.000 \Omega \mathrm{m}$ os maiores valores das resistividades das camadas nas regiões de Cachoeira do Arari, Ponta de Pedras, Soure e Salvaterra. Bezerra (1979) afirmou que as camadas apresentaram valores de até $43.000 \Omega \mathrm{m}$ a profundidades de 30 a 84 m, não apresentando problemas de salinização, sendo vários os locais em que se 
obtiveram valores superiores a $15.000 \Omega \mathrm{m}$ para as resistividades das camadas mais superficiais. Além disto, considerando, outros autores (i.e., Kobayashi, 1978; Cavalcanti, 1979) também verificam valores de resistividades das camadas interpretadas como formadoras do aqüífero em Salvaterra (de 4.000 a $500 \Omega \mathrm{m}$ ) são superiores aos valores observados para os aqüíferos de Ponta de Pedras (de 1.000 a $200 \Omega \mathrm{m}$ ) e do rio Paracauari (de 300 a $20 \Omega m$ ).

Os altos valores de resistividade observados para os materiais arenosos na área de Salvaterra (Bezerra, 1979), sugerem o fato de esta região ser geologicamente mais antiga que as outras duas áreas (i.e, Ponta de Pedras e rio Paracauari). Estes autores propuseram, ainda, que a drenagem, bem mais desenvolvida em Salvaterra (área elevada da ilha) que nas outras duas regiões, seria responsável pela lavagem e transporte de íons, o que resultaria em valores mais elevados para as resistividades das camadas na área de Salvaterra. Para Porsani (1981), a existência de um horizonte resistivo aflorante ou subaflorante de profundidade inferior a $25 \mathrm{~m}$ corresponde a materiais arenosos não salinizados (i.e., Paleocanal Guajará Mirim) ou fracamente salinizados (i.e., "Linha de Praia” São Miguel). Para este autor, isto indicaria a existência de uma camada resistiva superficial de pequena espessura e sem interesse hidrogeológico, representada por espesso pacote condutor, com espessuras entre meia a uma centena de metros, que corresponde a material argiloso ou arenoso salinizado, sobre o qual repousam paleocanais de paleocanais na ilha (Figura 14). 


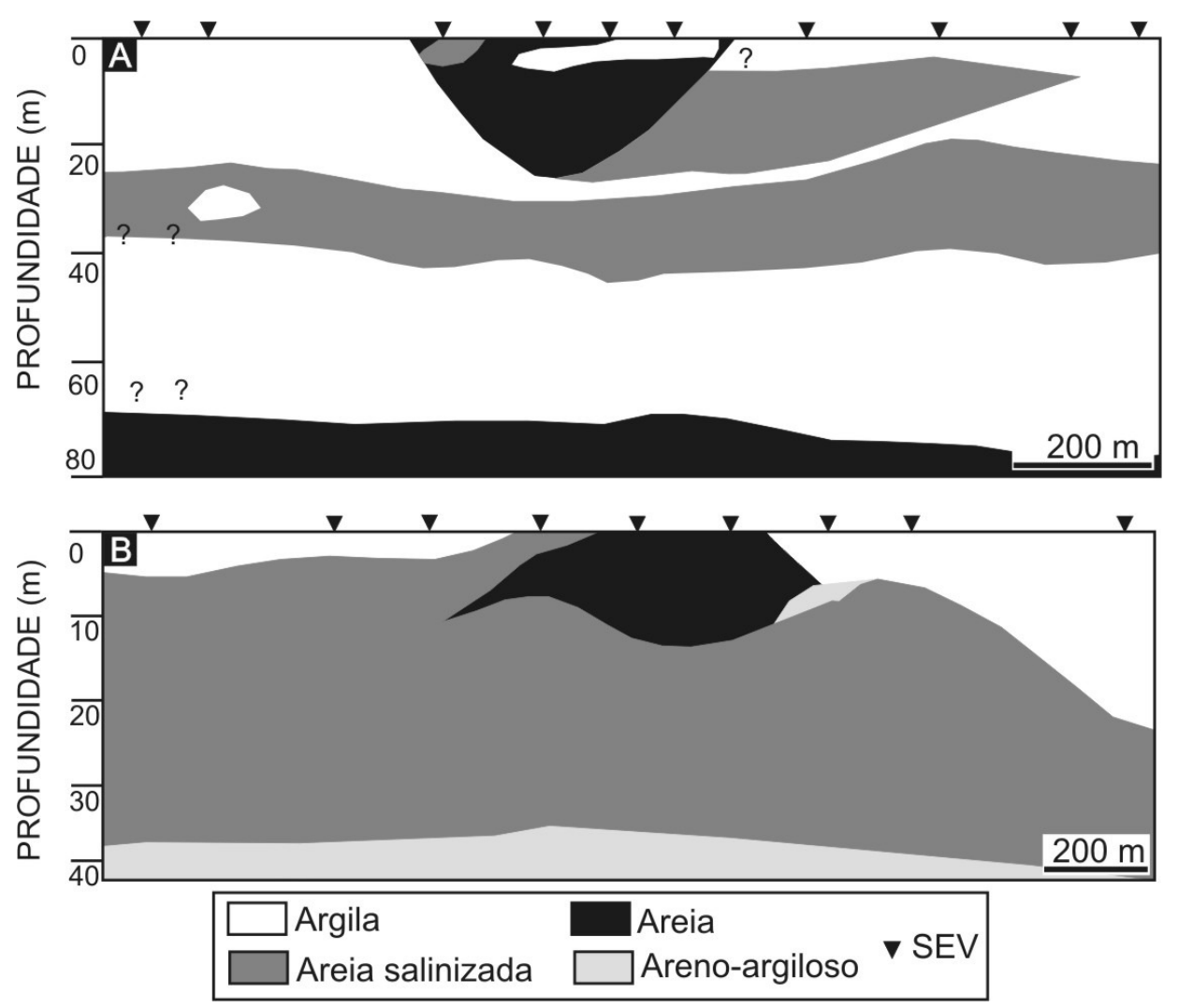

Figura 14 - Seções geoelétricas. (A) Paleocanal Guajará Mirim. (B) Linha de Praia - São Miguel. (modificada de Porsani, 1981).

\section{METODOLOGIA}

\subsection{Sensoriamento Remoto (SR)}

Para a caracterização morfoestrutural apresentada neste trabalho, procedeu-se com a elaboração do mapa de drenagem partindo-se de mapas digitais correspondentes à Folha SA-22 (Belém), elaborados pelo Instituto Brasileiro de Geografia e Proteção da Amazônia (SIPAM). Estes dados foram complementados com a extração visual de drenagens a partir da análise de imagens Landsat 5-TM (Refs 224-060 e 225-061, INPE) e Landsat 7-ETM 
(Refs 223-060 e 223-061, GLCF), adquiridas em Agosto de 2001. Essas cenas foram escolhidas por excepcionalmente mostrarem a área de estudo livre de nuvens.

As imagens Landsat foram processadas no aplicativo SPRING, estabelecendo-se vários esquemas de composição de bandas. A composição $4(\mathrm{R}), 5(\mathrm{G})$ e 7 (B) foi a que melhor possibilitou a visualização da rede de drenagem, tendo sido, portanto, escolhida para este mapeamento. Esta composição possibilitou, ainda, o mapeamento de feições morfológicas relacionadas a drenagens pretéritas que foram abandonadas antes do estabelecimento da drenagem atual, cuja análise foi importante para completar este estudo.

Com base no mapa de drenagem, procedeu-se com a extração manual dos lineamentos de drenagem. Os mapas de densidade destes elementos foram derivados de ferramentas de análise de bacias de drenagem disponíveis no aplicativo ArcGIS. Os diagramas em roseta, representativos das orientações dos lineamentos morfoestruturais, foram obtidos por análise automática no aplicativo Spring. A atribuição de propriedades e anomalias de drenagem a fatores tectônicos seguiu critérios apresentados em Holmes (1965), Howard (1967), Christofoletti (1981), Bloom (1991), Deffontaines \& Chorowicz (1991), Summerfield (1991), Berger (1994) e Kehew (1995).

\subsection{Radar de Penetração no Solo (GPR)}

A coleta de dados de GPR incluiu duas etapas: campo e escritório. Na fase de campo, realizada em Outubro de 2007, a aquisição dos dados foi feita utilizando-se o Sistema de GPR SYR-2 da Geophysical Survey Systems Inc., pertencente ao Museu Paraense Emílio Goeldi (MPEG). Este equipamento é equipado com bateria de $12 \mathrm{~V}$, com antena monoestática de $200 \mathrm{Mhz}$ ligada a sistema de registro computadorizado (Figura 15). Esta 
antena foi preferencialmente utilizada dada sua facilidade de operação, e bom desempenho no registro de depósitos com características litológicas e temporais similares na Região Bragantina, nordeste do Estado do Pará (Rossetti \& Góes, 2001; Rossetti et al. 2001; Rossetti, 2003).
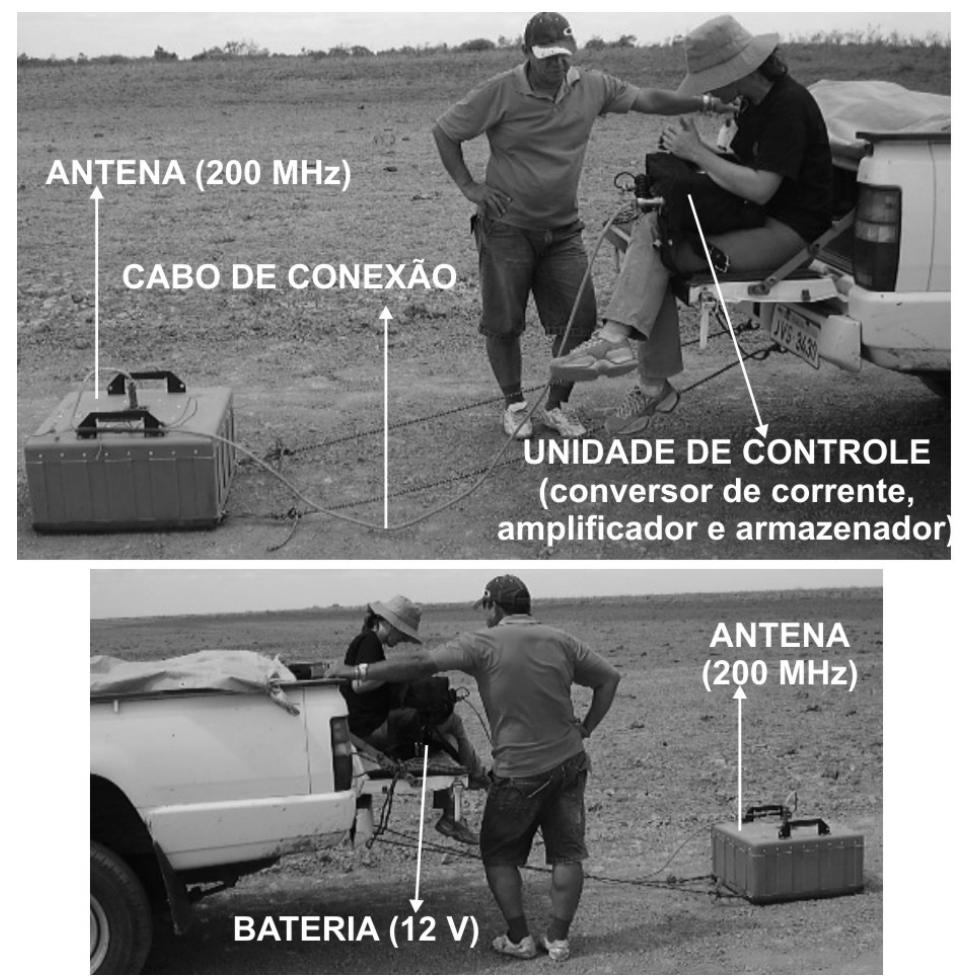

Figura 15 - Fotos ilustrando o equipamento de GPR utilizado na área pesquisada.

Aproximadamente $16 \mathrm{~km}$ de seções lineares de GPR foram coletadas ao longo da área de estudo. As seções foram adquiridas em modo contínuo e velocidade de caminhamento constante, com deslocamento da antena manual e mecânica, sendo o controle horizontal feito por meio de marcos espaçado, ora a cada $10 \mathrm{~m}$ e ora a cada $100 \mathrm{~m}$. As condições de aquisição dos dados foram "calibradas" de acordo com as necessidades locais, em geral utilizando os seguintes parâmetros: 512 amostras/escaneamento; constante dielétrica de 35; faixa entre 150-180 ns; razão de transmissão de $64 \mathrm{Khz}$; filtro vertical de transmissão 
alta de 30 Mhz; filtro vertical de transmissão baixa de $400 \mathrm{Mhz}$; e ganhos ajustáveis para cada seção.

Após coleta, procedeu-se com a transferência dos dados para o computador. O processamento das seções foi feito utilizando-se o aplicativo Radan for Windows (versão 6.0). O Radan é um programa versátil que combina feições encontradas nas versões $M S$ DOS do Radan I, Radan Basic e Radan III. Utilizou-se o filtro FIR Filter e Gains para melhorar a resolução e/ou amplificar, amenizando ruídos causados pela aquisição de dados no limite dos ganhos estabelecidos, ou para corrigir frequiências muito altas e muito baixas, a fim de proporcionar uma visualização mais clara das reflexões e, conseqüentemente, interpretação mais precisa do arcabouço tectono-estratigráfico da área de estudo.

Após processamento, as seções foram transferidas para o aplicativo Corel Draw, para facilitar o traçado das principais superfícies estratigráficas e a identificação dos padrões de reflexões (fácies de radar), observando-se a configuração e a geometria das mesmas. As interpretações foram anotadas diretamente sobre as seções, utilizando-se ferramentas próprias do aplicativo aqui adotado. As seções foram interpretadas tomando-se por base parâmetros relativos à configuração e geometria das reflexões de acordo com critérios apresentados na literatura (p.e., Payton, 1977; Van Heteren et al.1998) (Figura 16).

As seções de radar foram analisadas principalmente de forma bidimensional, e esporadicamente no caráter tridimensional. A primeira proporciona uma caracterização da geometria e heterogeneidade litológica (MacMechan et al. 1997), contribuindo, assim, para o reconhecimento, descrição e interpretação das unidades sedimentares. Na visualização tridimensional, as secções serão integradas de forma a possibilitar uma malha regular, que favoreça a caracterização de estratos geneticamente relacionados e de suas geometrias. 


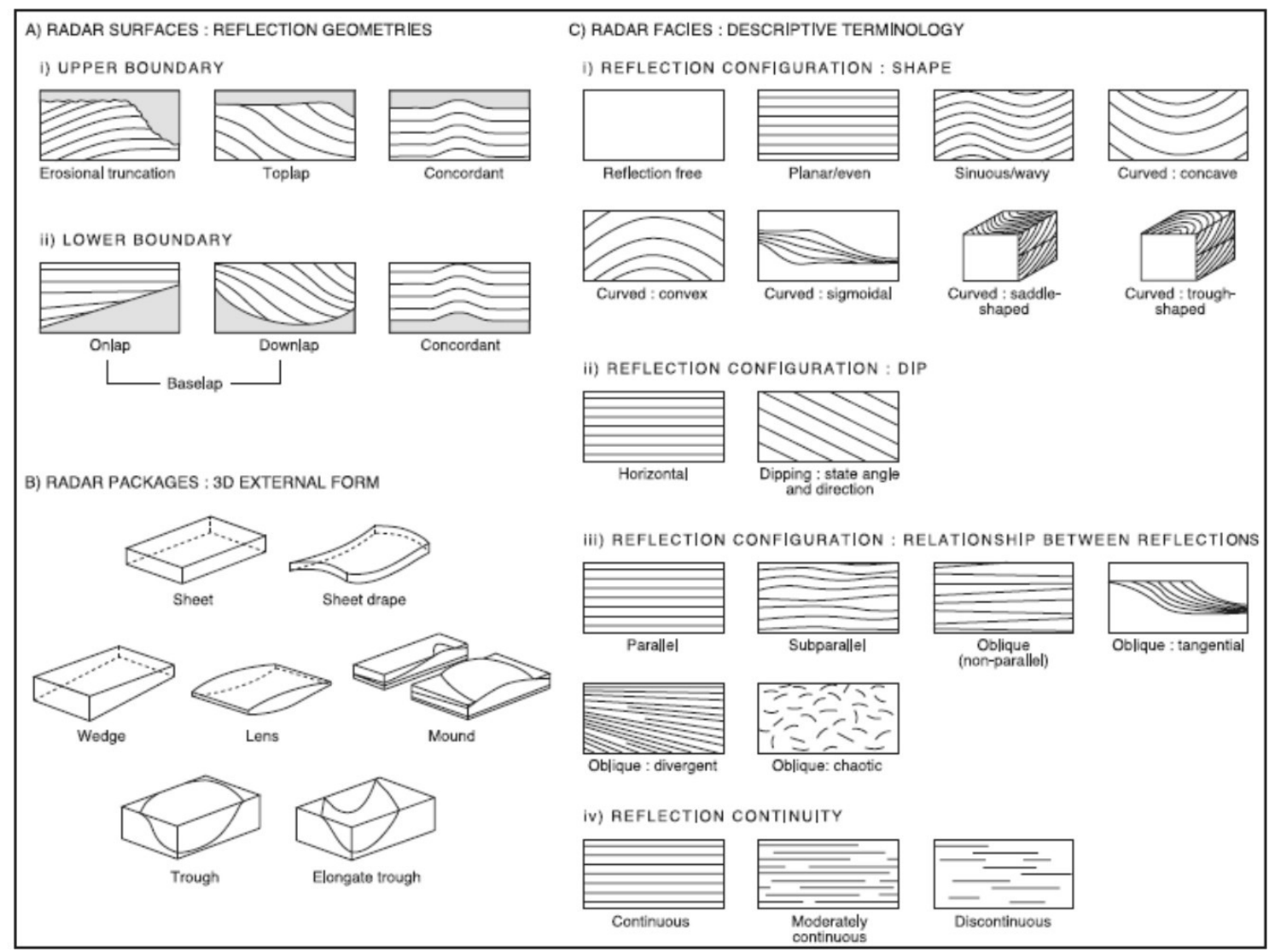

Figura 16 - Terminologia utilizada na descrição de superfícies estratigráficas e caracterização de estratos sedimentares em seções de GPR. (modificada de Neal, 2004).

\subsection{Sondagem Elétrica Vertical (SEV)}

Essa metodologia foi baseada em um total de 132 SEV adquiridas na ilha do Marajó/PA, entre as quais 111 representam dados reprocessados a partir de publicações anteriores (p.e., Cavalcanti, 1979; Kobayashi, 1979; Porsani, 1981), e 21 consistem de dados inéditos adquiridos na porção leste da ilha no período de setembro/2008. Os perfis de SEV estão posicionados na adjacência das cidades de Salvaterra, Joanes, Cachoeira do Arari e Ponta de Pedras (ver Figura 1). 
Para aplicação desta técnica utilizou-se o equipamento Resistivímetro GEOTEST RD300A, pertencente ao Departamento de Geofísica da Universidade Federal do Pará (DGfUFPA). Este possui potência nominal de saída de $1.000 \mathrm{~W}$, intervalo de leitura de potencial de 0,1 a $750 \mathrm{mV}$ e valor máximo de corrente de $800 \mathrm{~mA}$, tendo como fontes duas baterias de automóvel de $12 \mathrm{~V}$ cada (Figura 17). É válido lembrar que está técnica foi aplicada na área de estudo, por se tratar de terrenos sedimentares (Mendes, 2000; Souza, 2005), bem como ao sucesso de prospecções anteriores na ilha do Marajó (IDESP, 1974; Bezerra, 1979 e 1986; Cavalcanti, 1979; Kobayashi, 1979; Porsani, 1981; Gonzáles, 1984; Carrasquila et al. 1991). As 21 SEV foram coletadas com distâncias mínimas entre os eletrodos de corrente igual a $8,4 \mathrm{~m}(\mathrm{AB} / 2=4,2 \mathrm{~m})$ e a máxima de $640 \mathrm{~m}(\mathrm{AB} / 2=320 \mathrm{~m})($ Anexo $\mathrm{I}) . \mathrm{Na}$ coleta dos dados foram observadas a integridade dos cabos utilizados e as distâncias entre os eletrodos, cujos espaçamentos foram regularmente distribuídos em escala métrica. Ruídos locais (p.e., tubulações, fiações elétricas e telefônicas, proximidade com poços d'água) foram cuidadosamente registrados com o intuito de avaliar a sua interferência nas informações obtidas.

É desejável que investigação por SEV deva ser feita em estações distribuídas de maneira regular na superfície, onde o terreno prospectado seja caracterizado por ruas/estradas lineares por centenas de metros e não/pouco asfaltadas para cravar os eletrodos, com baixo fluxo de automóveis e pedestres para evitar que os cabos sejam partidos ou que alguém toque nos eletrodos quando da injeção de corrente. Assim, a área de prospectada mostrou excelente disposição para execução da sondagem, pois a mesma possui pouquíssimo desenvolvimento urbano, além de ter topografia quase planar. Ressaltase que apenas a região de Salvaterra, em seu núcleo urbano, a abertura entre os eletrodos ( $\mathrm{AB}$ e $\mathrm{MN}$ ) ficou um tanto limitada, devido aos caracteres acima citados serem pouco 
marcados. Terminada a fase de campo, as novas SEV adquiridas (i.e., 21) e as 111 derivadas de publicações anteriores, foram processadas usando o programa de inversão IPI2Win desenvolvido pela GEOSCAN-M Ltd.

Os dados geoelétricos foram interpretados com base na integração de dado geológico de superfície e subsuperfície. As informações de superfície incluíram umas poucas exposições de afloramentos ao longo de falésias costeiras, bem como, escavações de extração de laterita e areia. E as de subsuperfície englobaram dados sedimentológico e de datação radiogênica, derivadas de vários testemunhos de sondagem com profundidade de até 120 m descritas em publicações anteriores (p.e., Bemerguy, 1981; Rossetti et al. 2007; Rossetti et al. 2008b; Miranda et al. 2009; Castro et al. 2010; Rossetti, 2010). Enquanto o volume de dados de SEV aqui considerados serviu para fornecer uma ampla idéia da distribuição litológica por toda a área estudada, os novos dados adquiridos durante esse estudo tentaram registrar a expressão em subsuperfície de estruturas (i.e., tectônicas) selecionadas mapeadas com base em informações de sensoriamento remoto. 


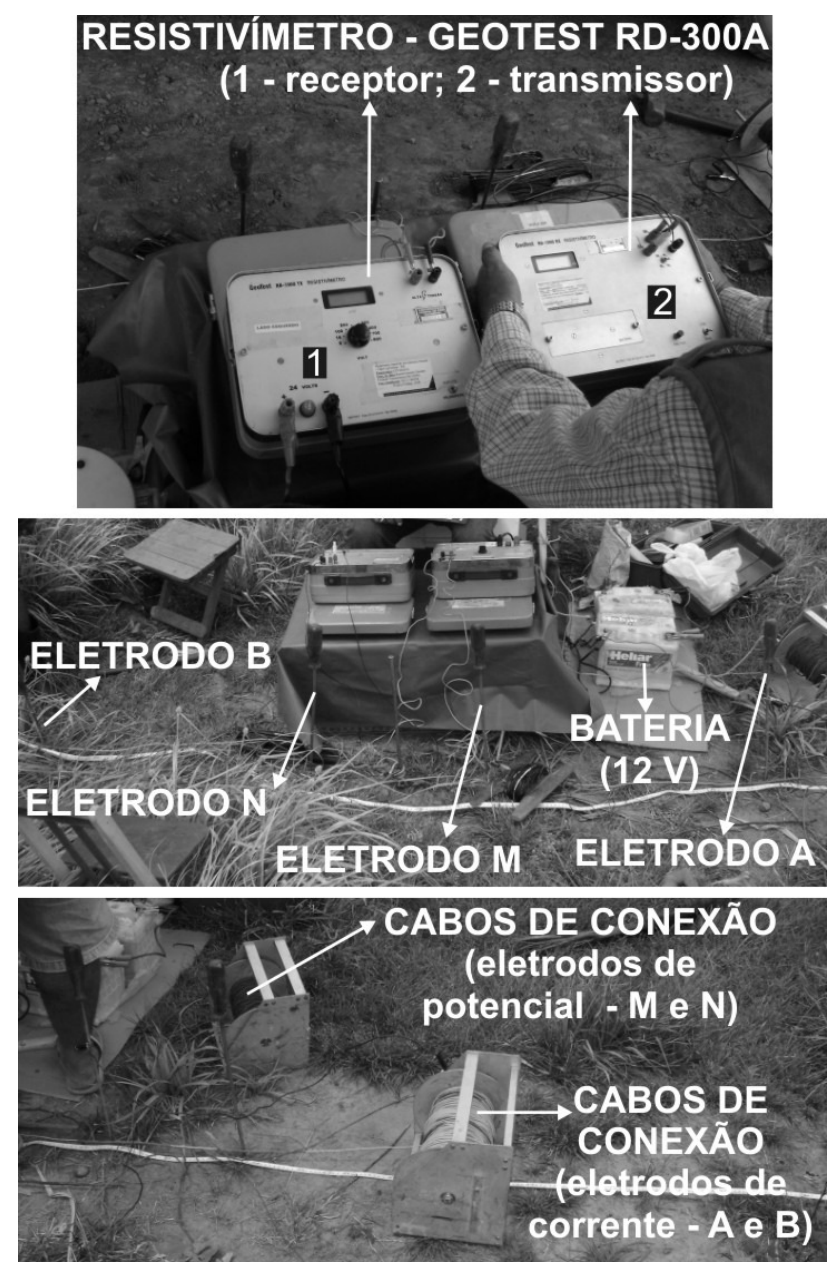

Figura 17 - Fotos ilustrando o equipamento de SEV utilizado na área de estudo.

\section{RESULTADOS}

Neste capítulo serão apresentados os dados referentes à análise de drenagem no tocante à caracterização das bacias de drenagem e aos aspectos morfoestruturais da área de estudo. Adicionalmente, serão descritos os dados de sondagem elétrica vertical e os produtos obtidos com a aplicação de radar de penetração no solo. Procurar-se-á, com isto, disponibilizar um conjunto de informações de superfície e subsuperfície, que servirá de 
base para testar a hipótese se anomalias de drenagem e lineamentos morfoestruturais detectados em superfície refletem estruturas tectônicas desenvolvidas em associação a depósitos miocenos e pós-miocenos do leste da ilha do Marajó, bem como discutir o modelo tectônico mais provável aplicado a esta área.

\subsection{Caracterização das Bacias de Drenagem}

A drenagem da área de estudo é constituída por três bacias hidrográficas principais, correspondentes aos rios Arari, Camará e Paracauari (Figura 18). Estas bacias compõem rede de drenagem de densidade heterogênea, que pode ser categorizada em 5 classes relativas: muito baixa, baixa, média, alta e muito alta (Figura 19). Destas, as classes muito baixa a média são as dominantes. 


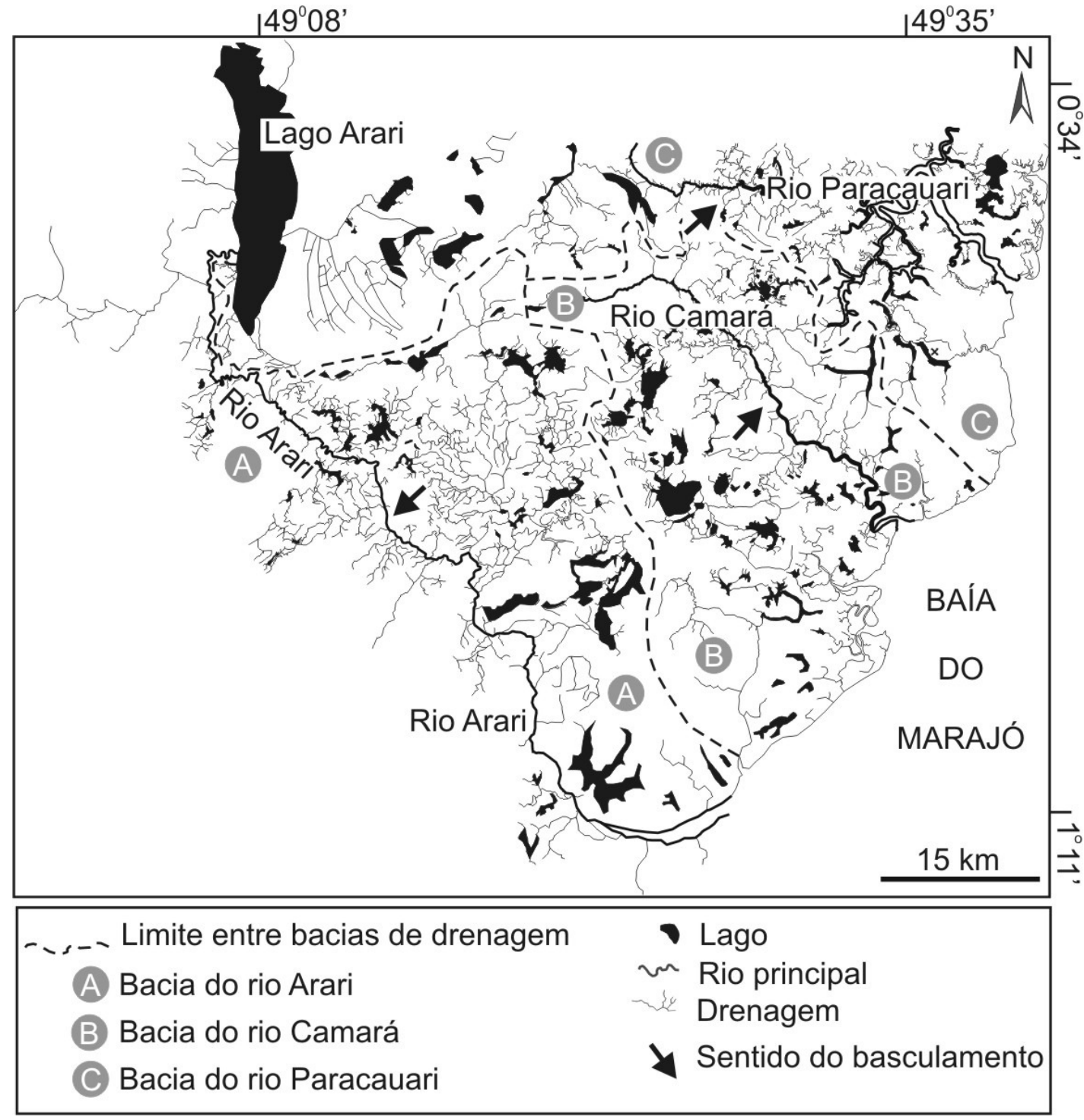

Figura 18 - Mapa das bacias de drenagem estudadas no leste da ilha do Marajó, derivado da combinação de dados digitais do IBGE/SIVAM com imagem Landsat. 


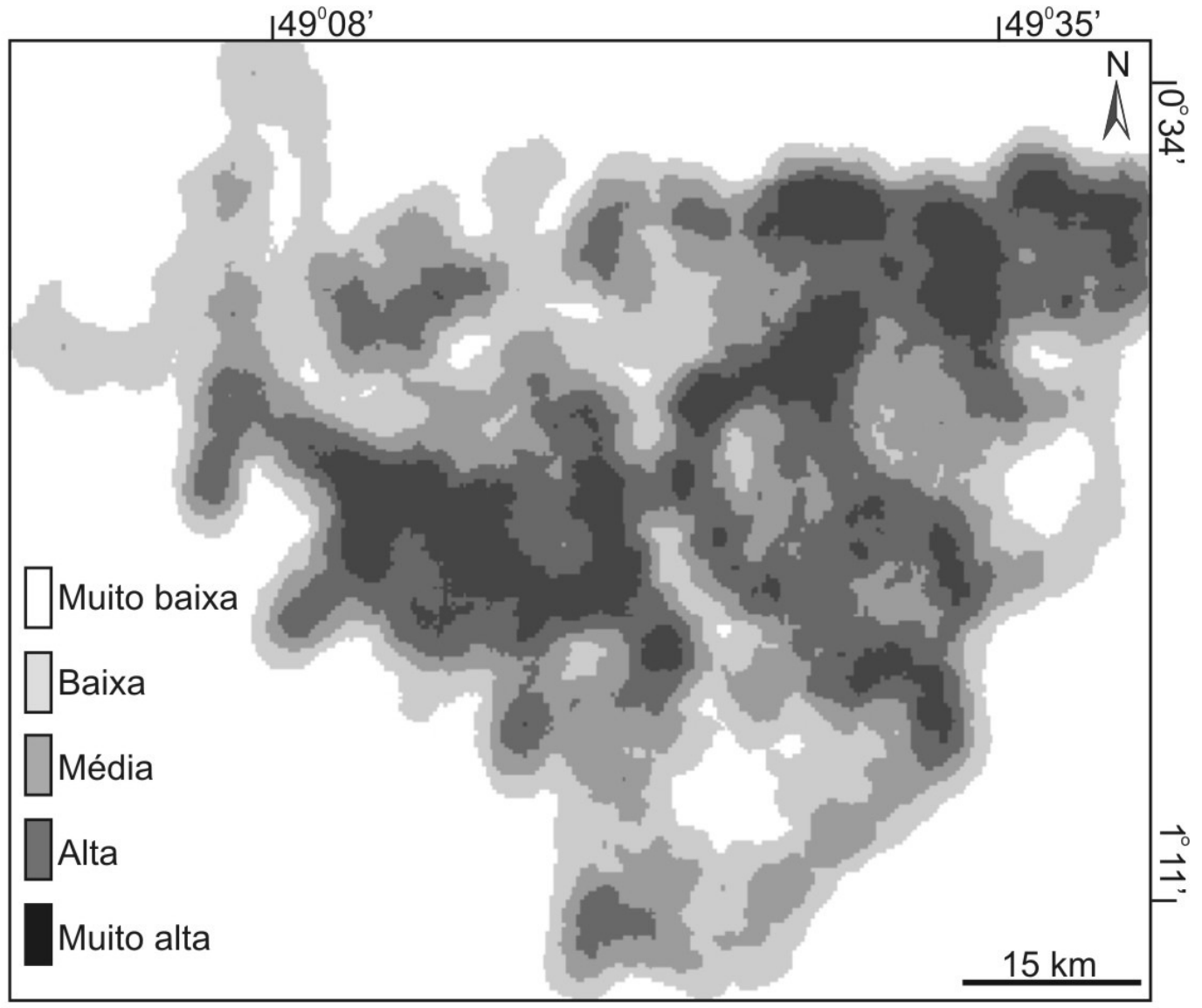

Figura 19 - Mapa de densidade de drenagem.

\subsubsection{Bacia de drenagem do rio Arari (BDRA)}

A BDRA é a mais extensa da área de estudo, sendo grande parte posicionada em sua porção ocidental, onde totaliza $1.688 \mathrm{~km}^{2}$ (Figura 20). Limita-se com os rios Jenipapacu a norte, das Almas a leste, Anajás Mirim a oeste, e Laranjeiras a sul (ver Figura 1). Esta bacia é do tipo exorréica, e possui drenagem de densidade média, sendo caracterizada por tributários de comprimentos muito maiores em sua margem esquerda do que em sua margem direita. Os padrões de drenagem dominantes em sua porção central são dos tipos 
treliça recurvada e multibacinal. No extremo norte ocorre, de forma isolada, padrão subparalelo e, a sudeste, multibacinal a subtreliça (Figura 20).

Característica marcante na BDRA são anomalias de drenagem (Figura 21). Estas consistem, principalmente, em cursos d'água com ângulo de inflexão de $90^{\circ}$. Um bom exemplo disto é verificado ao longo do rio Arari, onde ocorrem vários segmentos com mudança abrupta de curso de forma a caracterizar drenagem retangular (Figura 21A). Esta bacia possui, ainda, como feição marcante, uma abundância de lagos (Figura 21B), particularmente em sua porção mediana e à jusante, onde ocorre lagos de maiores dimensões. Em geral, os lagos têm larguras e comprimentos variando de 0,4 a $5 \mathrm{~km}$ e de 0,6 a $10 \mathrm{~km}$, respectivamente. Na porção sudeste da bacia ocorre um conjunto de lagos estreitos e alongados e, por vezes, ramificados. A análise de imagens Landsat revelou que estas feições estão dispostas sob forma de vários segmentos isolados, alguns em continuidade lateral com morfologias relacionadas a paleocanais (ver descrição adiante) que, no conjunto, revelam terem sido parte de um sistema de drenagem (Figura 21C). Adicionalmente, o rio Arari tem, como forte anomalia de drenagem, meandros comprimidos (Figura 21D, E), que se manifestam principalmente no extremo norte e noroeste da bacia. Esses meandros passam rapidamente, à jusante, para canais retilíneos. É interessante observar, ainda, que os padrões de drenagem mudam bruscamente de um tipo a outro, o que é particularmente ilustrado no extremo norte da bacia (Figura 20). 


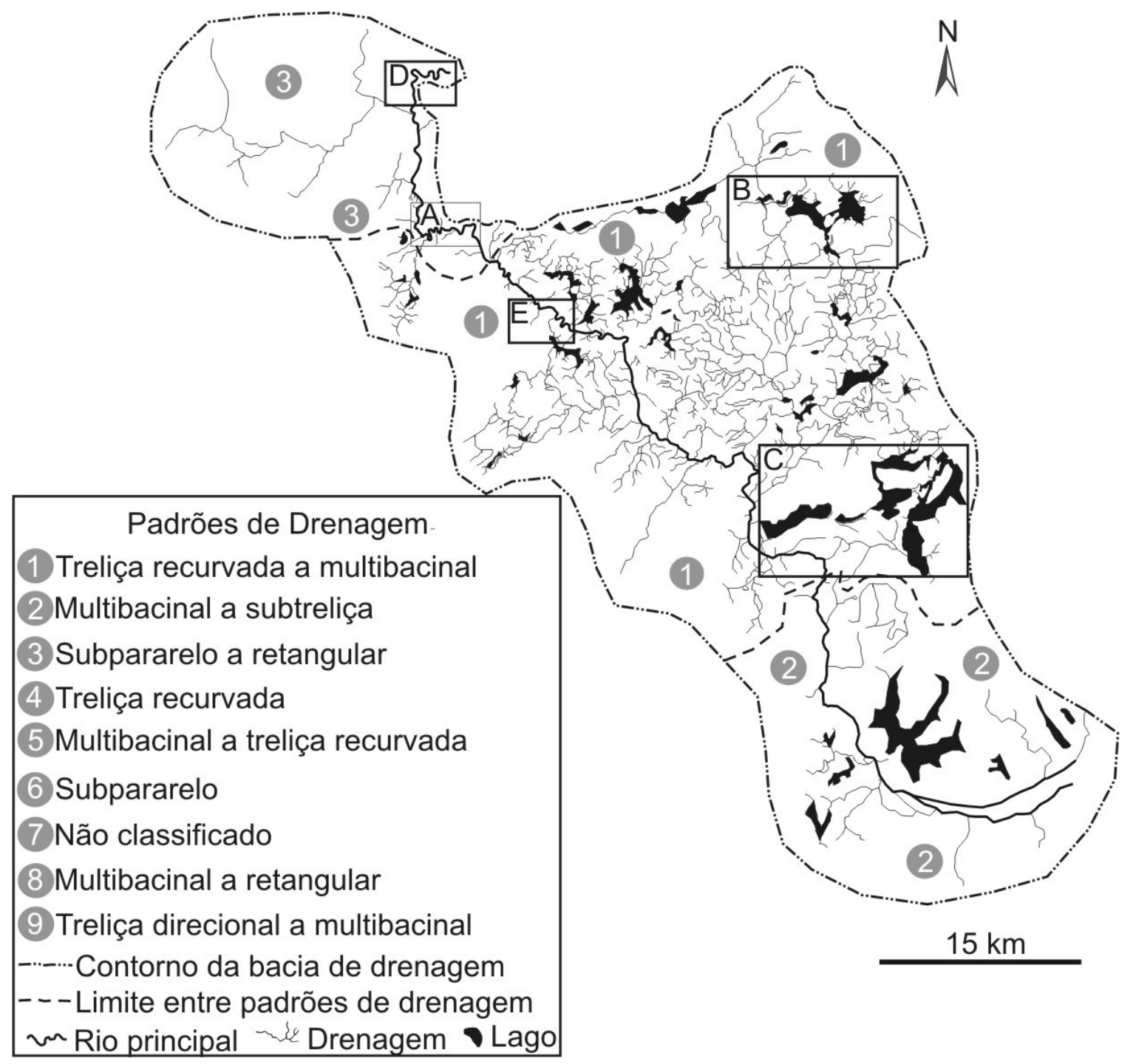

Figura 20 - Bacia de drenagem do rio Arari, com os principais padrões de drenagem. As letras A, B, C indicam anomalias de drenagem ilustradas na figura 21. 

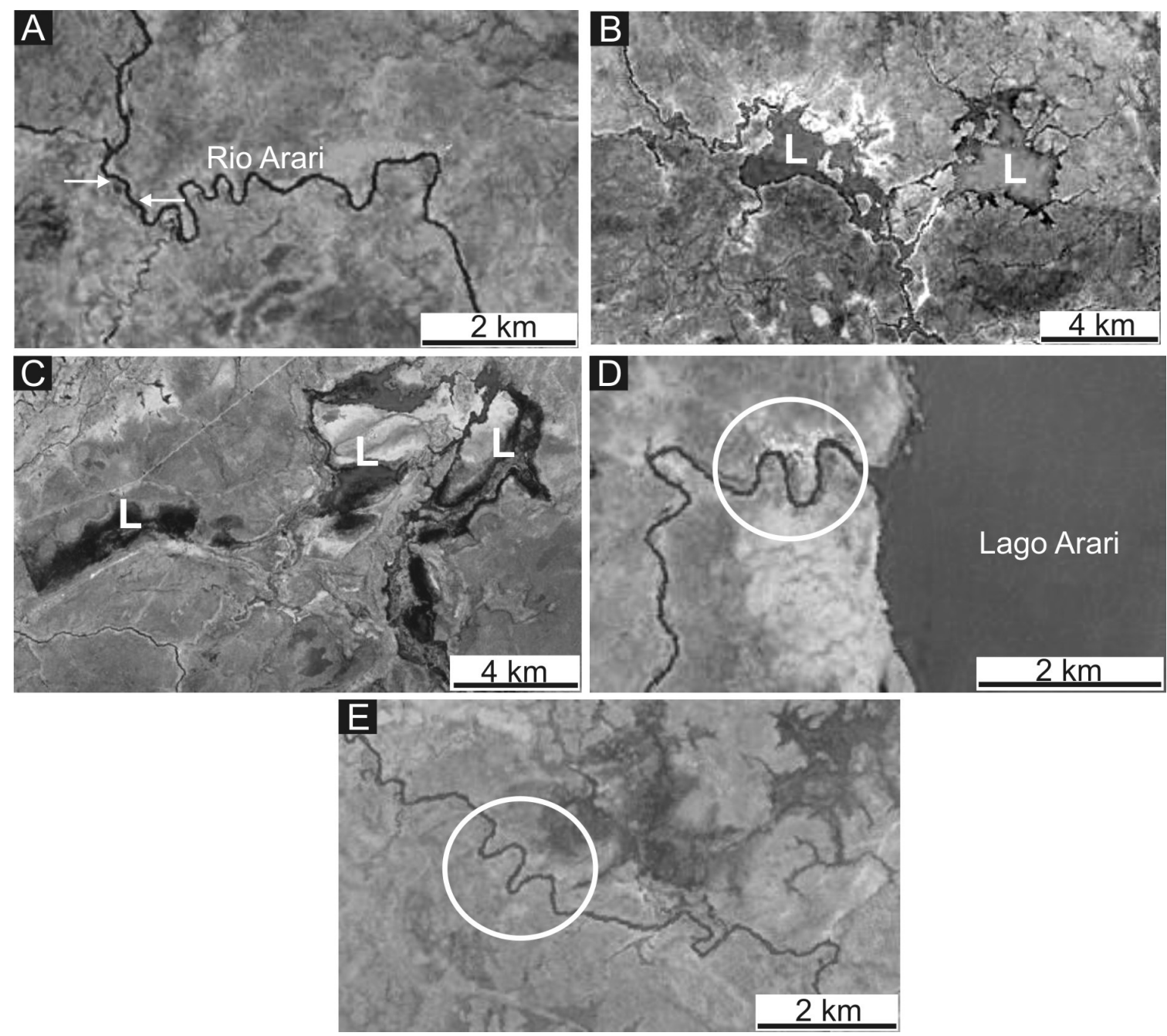

Figura 21 - Imagem Landsat das anomalias de drenagem na BDRA (ver localização na

figura 20). A. Mudanças rápidas no curso do rio Arari, com inflexões de $90^{\circ}$ (seta). B e C.

Lagos formados a partir do abandono de canais (L). D e E. Meandro comprimido (círculos).

\subsubsection{Bacia de drenagem do rio Camará (BDRC)}

Esta bacia localiza-se na porção central da área de estudo, onde perfaz um total de $751 \mathrm{~km}^{2}$ (Figura 22). A norte é limitada pelo rio São Miguel e, a sul, pelo rio Abaí (ver Figura 1). O rio Camará drena, em geral, de NW para SE, porém à montante ocorre longo 
trecho com forte inflexão na direção WSW-ENE, configurando rápido desvio (quase ortogonal) de drenagem. A bacia é do tipo exorréica, com distribuição de densidade de canais mais variável do que na bacia do rio Arari, oscilando entre baixa e média (Figura 19). Contrariamente à BDRA, os tributários possuem comprimentos maiores na margem direita do rio Camará.

Similarmente à BDRA, esta bacia mostra várias anomalias de drenagem. Por exemplo, a morfologia do rio Camará é dominantemente retilínea, principalmente em seu curso médio, com súbita mudança para meandrante no extremo jusante, onde meandros apertados e ortogonais acham-se presentes. Uma característica marcante deste rio é a presença de tributários com segmentos retilíneos contendo trechos com alargamentos bruscos, formando lagos alongados. Estes lagos, que chegam a atingir até $5 \mathrm{~km}$ de extensão e 1,7 km de largura máxima (Figura 23A), estão concentrados particularmente na margem direita do rio Camará, onde caracteriza drenagem do tipo multibacinal. Neste caso, os lagos possuem geometria subalongada a subarredondada e largura e comprimento variáveis, chegando a 3,5 km e cerca de $8 \mathrm{~km}$, respectivamente. Uma situação interessante ocorre à jusante do rio Camará, onde o canal apresenta meandros localizados e possui, em suas adjacências, lagos que formam segmentos alongados e ramificados em continuidade lateral (Figura 23B).

Não há padrão de drenagem uniforme na BDRC, que é dominada por vários padrões complexos, incluindo-se, além do multibacinal, treliça recurvada e subparalelo. Estes tipos, bem como a mudança brusca entre eles, particularmente de treliça recurvada a mutibacinal e subparalelo no extremo norte, nordeste e sudeste, são indicativos de anomalias de drenagem (Figura 22). 


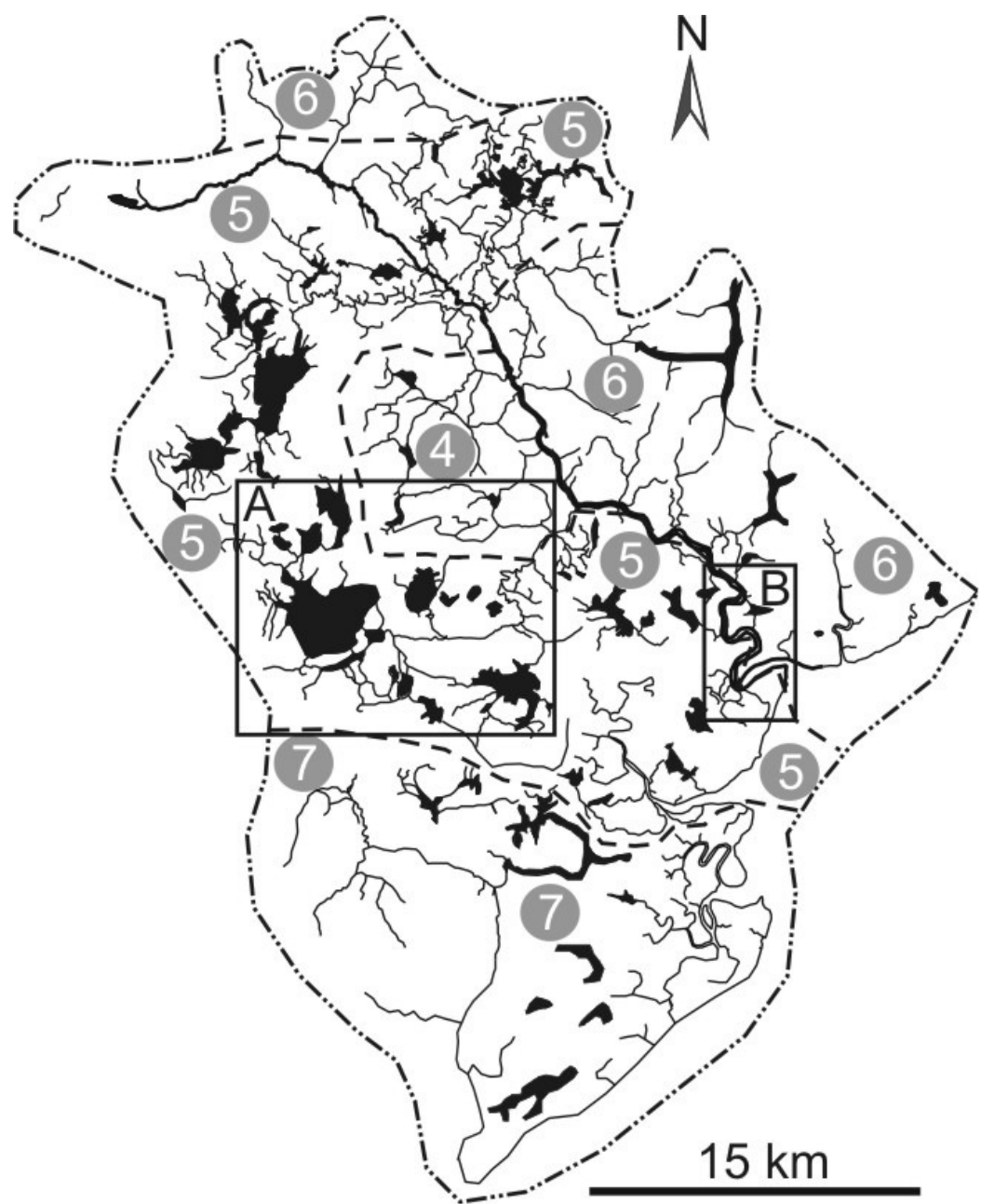

Figura 22 - Bacia de drenagem do rio Camará (ver legenda na figura 20). A e B indicam anomalias de drenagem ilustradas na figura 23. 

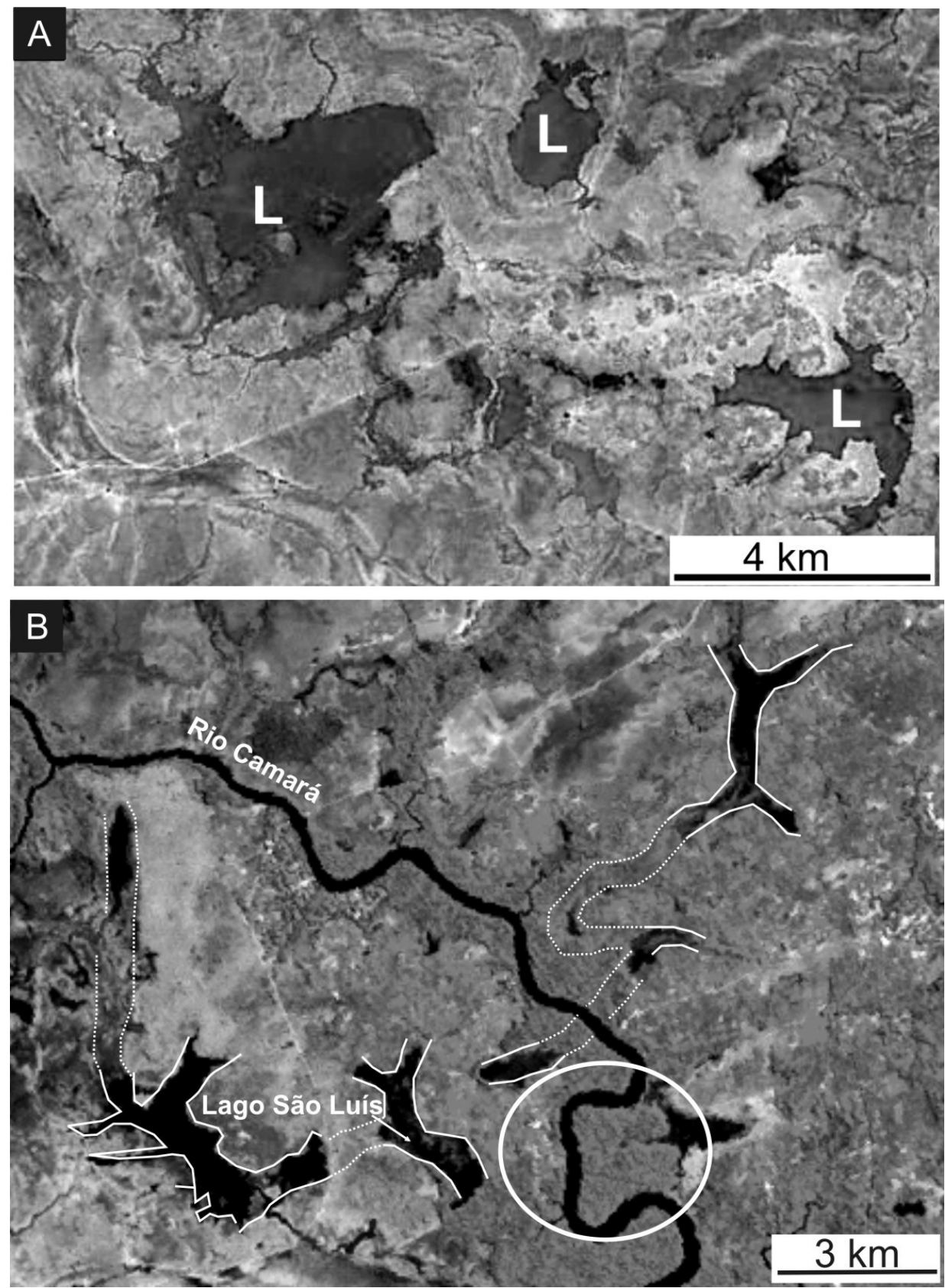

Figura 23 - Imagem Landsat das anomalias de drenagem na BDRC (ver localização na figura 22). A. Lagos formados a partir do alargamento súbito de canais (L). B. Setor do rio Camará com variação de trechos retilíneos para meandros comprimidos (círculo). Observar, também, grupo de lagos alongados (delimitados por linhas contínuas) que estão em continuidade lateral com paleocanais (linhas pontilhadas). 


\subsubsection{Bacia de drenagem do rio Paracauari (BDRP)}

Esta é a menor bacia hidrográfica da área de estudo, estando posicionada em sua parte oriental, onde totaliza $706 \mathrm{~km}^{2}$ (Figura 24). A sudoeste, o rio Paracauari liga-se ao rio Cambu (ver Figura 1). O rio Paracauari possui desvios moderados de seu curso d'água, sendo que, à montante, flui no sentido E-W, enquanto que, à jusante, sofre fortes inflexões (i.e., ângulo de $90^{\circ}$ ), fluindo para $\mathrm{N}$ e, então, para SE.

A BDRP é do tipo exorréica, de densidade média. Os tributários são mais longos na margem direita do que na margem esquerda do rio Paracauari, embora não tanto quanto no caso do rio Camará. O padrão de drenagem, em geral, é o treliça recurvada a multibacinal, sendo que, para oeste, ocorre treliça direcional a multibacinal, enquanto que, para o extremo sul, predominam os tipos multibacinal e retangular (Figura 24). Anomalia de drenagem comum consiste em meandros localizados e comprimidos. Este último grada a canais relativamente mais retilíneos à montante da bacia (Figura 25A).

Uma característica marcante da BDRP é a natureza fortemente meandrante do canal principal, em seu baixo curso, enquanto que, para montante, segmentos de canal meandrante mudam rapidamente a retilíneos, configurando junções em ângulos retos Similarmente à BDRC, lagos dispostos em segmentos alongados e ramificados lateralmente contínuos ocorrem, também, nesta bacia (Figura 25B). Tais feições ocorrem, mais especificamente, no extremo leste e sul da bacia, onde os tributários formam padrão anastomosado. 


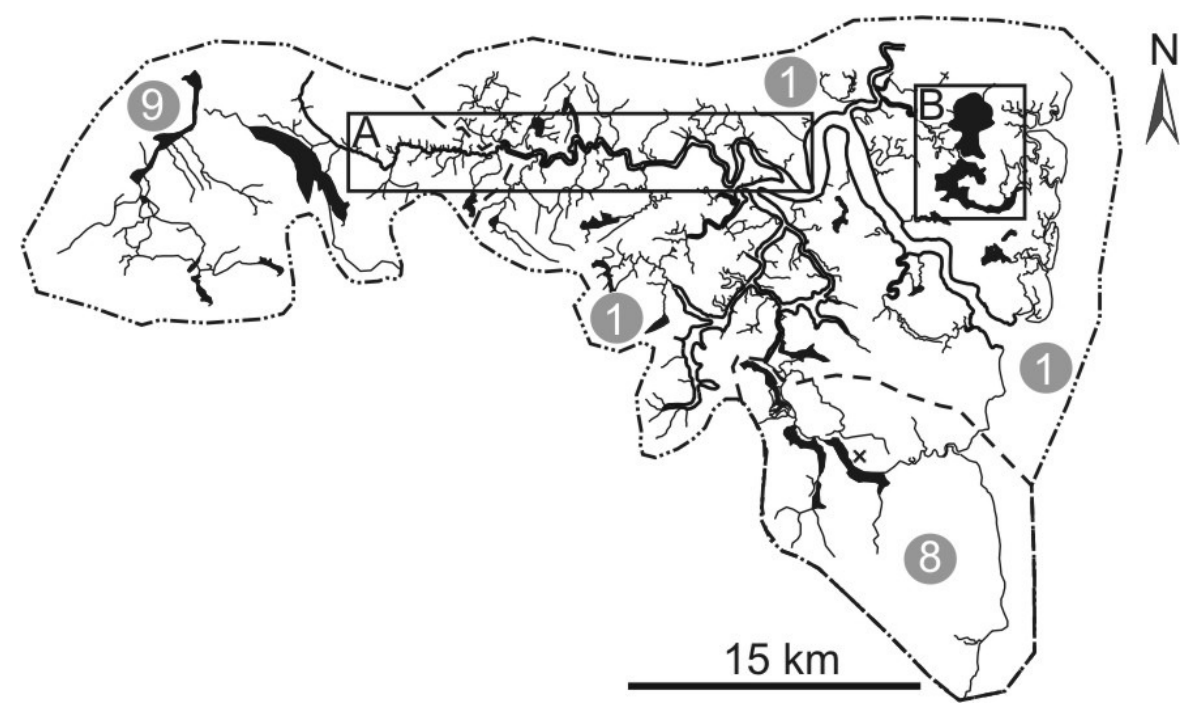

Figura 24 - Bacia de drenagem do rio Paracauari (ver legenda na figura 21). A e B localizam as anomalias de drenagem ilustradas na figura 25.
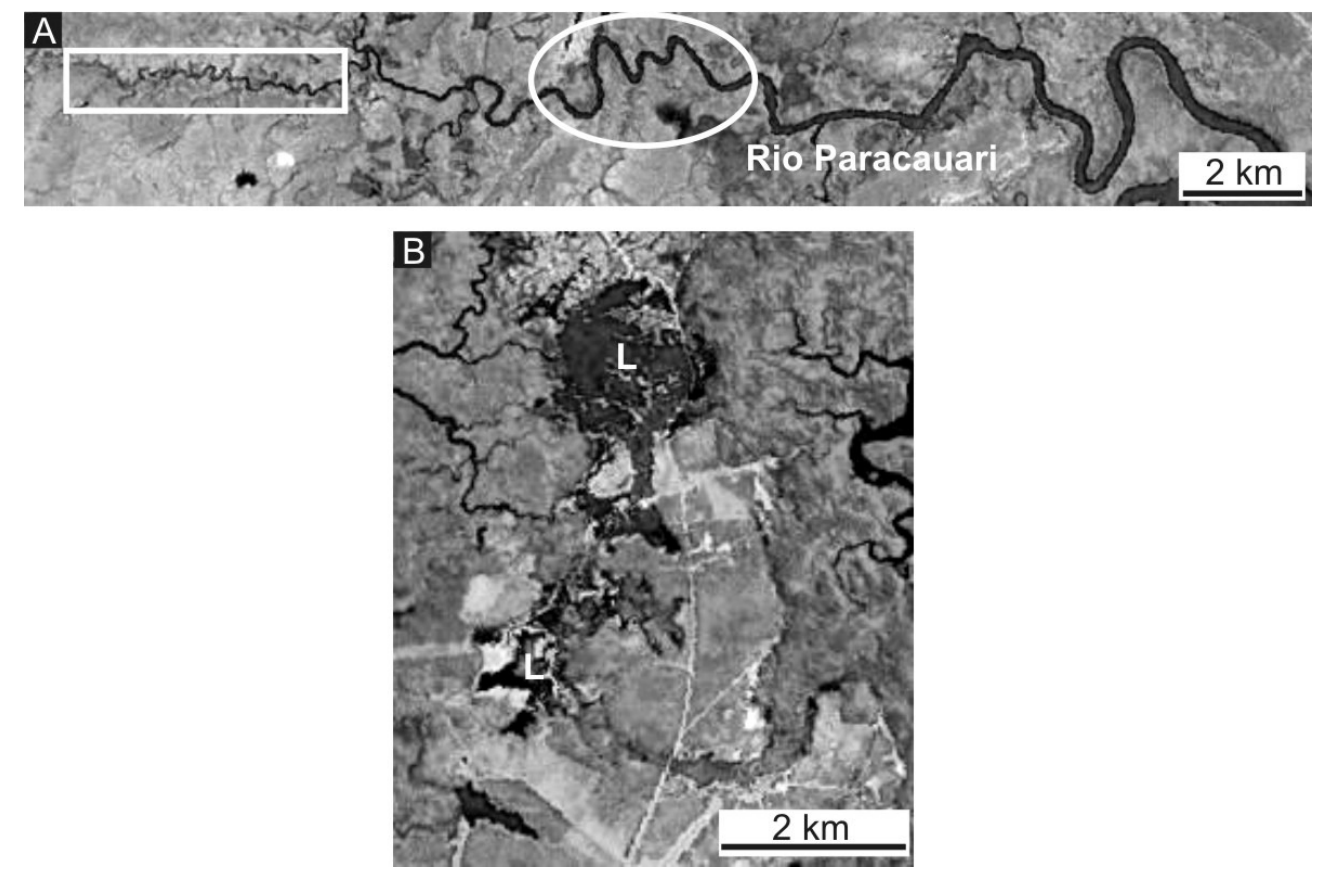

Figura 25 - Imagem Landsat das anomalias de drenagem na BDRP (ver localização na figura 24). A. Canais meandrantes (círculo) que mudam para retilíneos (quadrado). B. Lagos alongados devido ao rápido alargamento de canais (L). 


\subsubsection{Lineamentos Morfoestruturais}

Em combinação com as anomalias de drenagem, os lineamentos morfoestruturais foram mapeados com o intuito de se levantar dados adicionais que pudessem contribuir para se testar o controle tectônico dos sistemas de drenagem da área de estudo (Figura 26). Observa-se que o traçado dos lineamentos morfoestruturais foi estendido além dos limites da área de estudo, a fim de permitir melhor visualização de sua continuidade.

Os diagramas em roseta dos lineamentos morfoestruturais, derivados dos dados de freqüências e comprimentos absolutos (Figura 27 e Tabela 3), mostraram modas principais para NW-SE e NE-SW, e subordinada aproximadamente para E-W e NNE-SSW/NNWSSE. O mapa de densidade de lineamentos (Figura 28) levou ao reconhecimento de dois compartimentos na área de estudo. O compartimento I localiza-se na porção centro-leste, correspondente às margens esquerda e direita dos rios Arari e Paracauari, respectivamente, além do médio e baixo curso do rio Camará. Neste compartimento, ocorre densidade de lineamentos alta, sendo estes orientados, preferencialmente, para NW-SE e NE-SW. O padrão de drenagem característico é o treliça recurvada, direcional, multibacinal e retangular. A ocorrência de paleocanais (ver descrição abaixo) é baixa neste setor. O compartimento II corresponde ao restante da área, ou seja margens direita e esquerda dos rios Arari e Paracauari, respectivamente, além do alto curso do rio Camará. Este setor possui densidade de lineamentos muito baixa a média, sendo estes direcionados, em geral, para NE-SW. O padrão de drenagem neste setor é o treliça recurvada, subtreliça, subparalelo e retangular. 


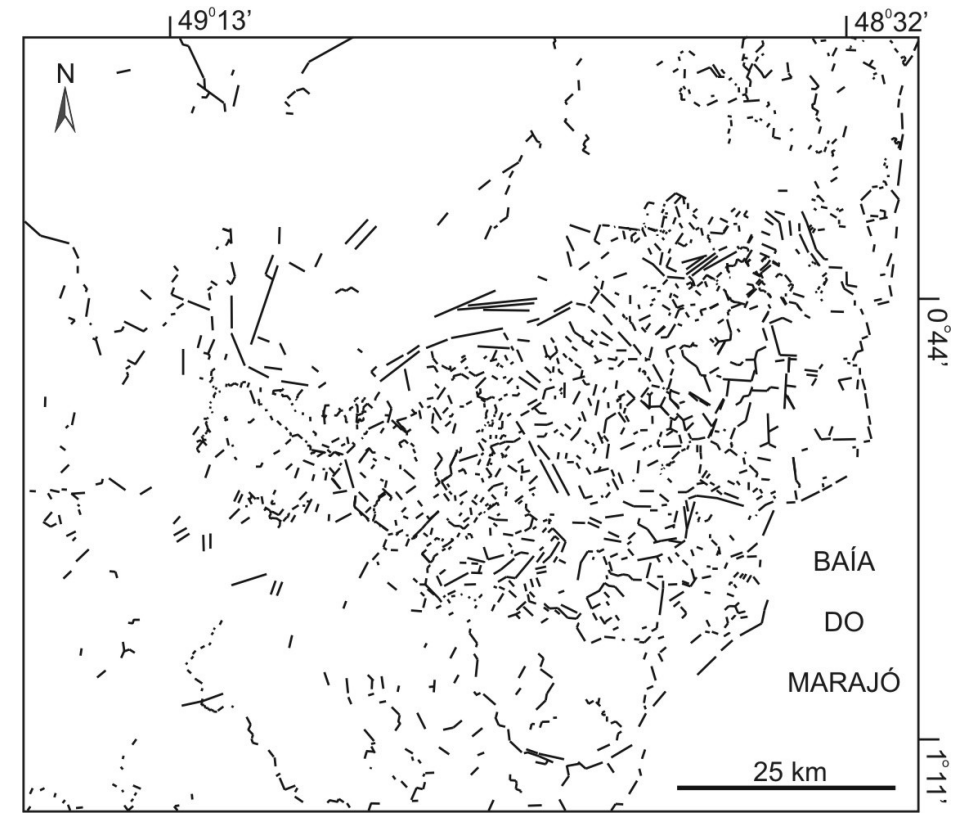

Figura 26 - Lineamentos morfoestruturais derivados da análise da rede de drenagem atual.
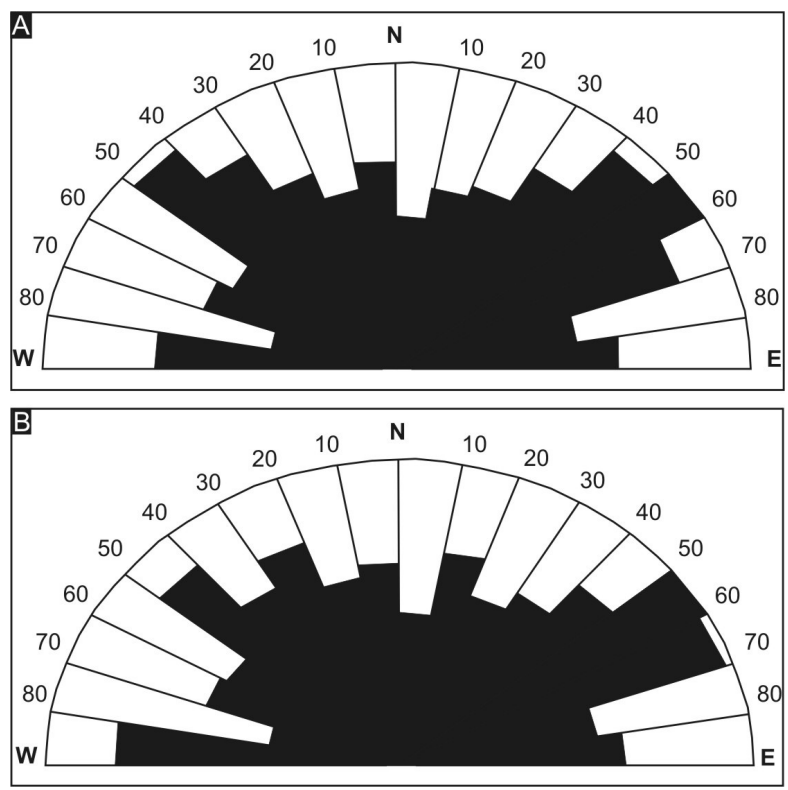

Figura 27 - Diagramas em roseta dos lineamentos morfoestruturais. A. Frequência absoluta ilustrando modas principais para NW e NE. B. Comprimento absoluto ilustrando modas principais para NW e NE. Notar que estas orientações são coincidentes com as obtidas para frequência absoluta, mostradas no diagrama em roseta da figura 27A. 
Tabela 3 - Dados estatísticos dos lineamentos morfoestruturais em intervalos de $10^{\circ}$.

\begin{tabular}{|c|r|r|r|r|}
\hline $\begin{array}{c}\text { Início e fim do } \\
\text { segmento (graus) }\end{array}$ & $\begin{array}{c}\text { Freqüência } \\
\text { absoluta (\%) }\end{array}$ & $\begin{array}{c}\text { Comprimento } \\
\text { absoluto (km) }\end{array}$ & $\begin{array}{c}\text { Freqüência } \\
\text { relativa (\%) }\end{array}$ & $\begin{array}{c}\text { Comprimento } \\
\text { relativo (km) }\end{array}$ \\
\hline $0-10$ & 69 & 0,60 & 5,10 & 5,20 \\
\hline $10-20$ & 57 & 0,53 & 4,21 & 4,56 \\
\hline $20-30$ & 93 & 0,92 & 6,87 & 8,90 \\
\hline $30-40$ & 109 & 0,94 & 8,06 & 6,34 \\
\hline $40-50$ & 104 & 0,74 & 7,69 & 5,33 \\
\hline $50-60$ & 85 & 0,62 & 6,28 & 4,79 \\
\hline $60-70$ & 71 & 0,56 & 5,25 & 5,82 \\
\hline $70-80$ & 67 & 0,68 & 4,95 & 4,06 \\
\hline $80-90$ & 56 & 0,47 & 4,14 & 5,42 \\
\hline $90-100$ & 76 & 0,63 & 5,62 & 5,06 \\
\hline $100-110$ & 66 & 0,59 & 4,88 & 6,34 \\
\hline $110-120$ & 75 & 0,74 & 5,54 & 5,51 \\
\hline $120-130$ & 90 & 0,64 & 6,65 & 7,02 \\
\hline $130-140$ & 104 & 0,82 & 7,69 & 4,47 \\
\hline $140-150$ & 58 & 0,52 & 4,29 & 4,67 \\
\hline $150-160$ & 62 & 0,54 & 4,58 & 3,00 \\
\hline $160-170$ & 38 & 0,35 & 2,81 & 6,43 \\
\hline $170-180$ & 73 & 0,75 & 5,40 & \\
\hline
\end{tabular}

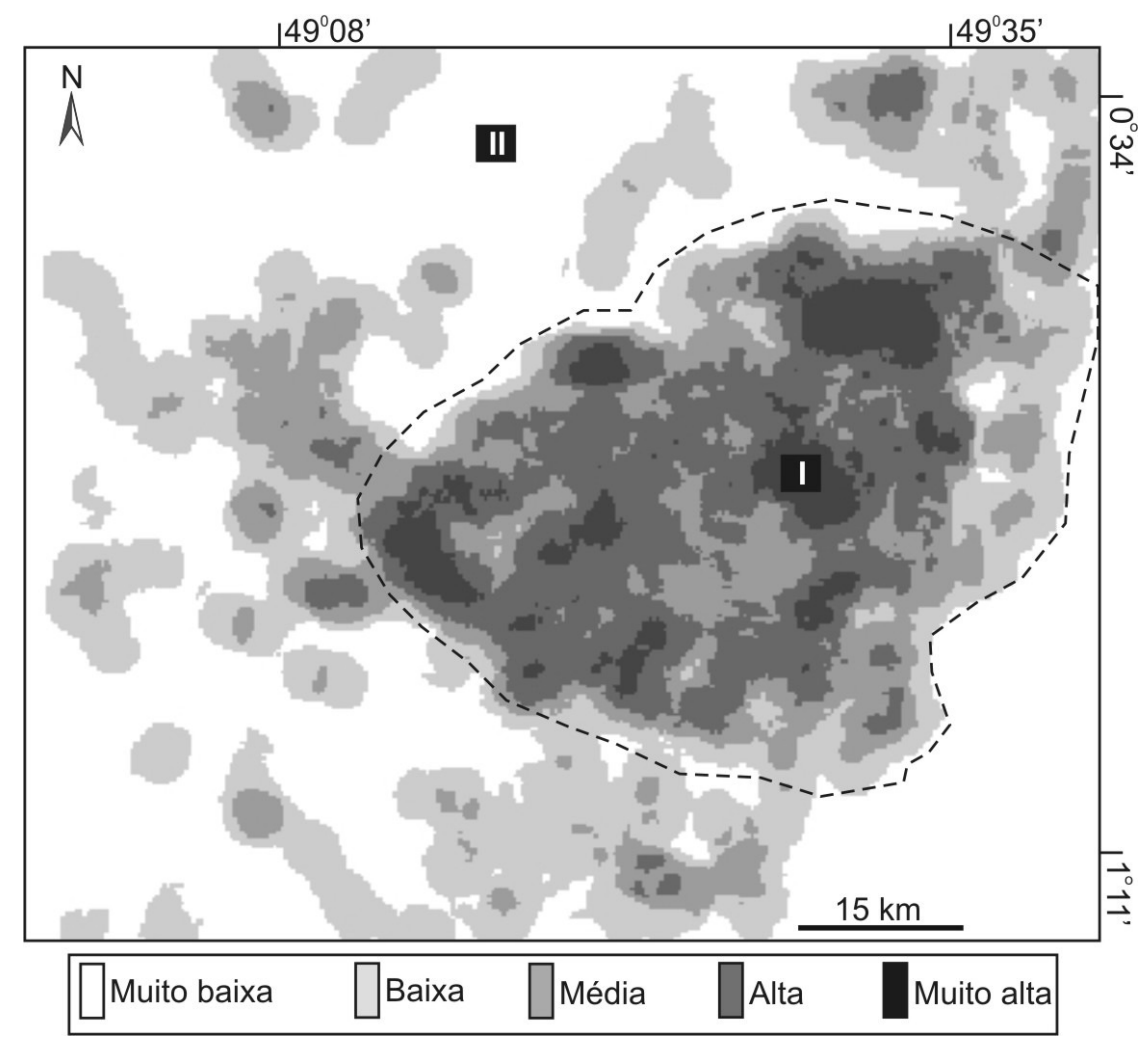

Figura 28 - Mapa de densidade de lineamentos tectônicos. As letras I e II indicam compartimentos morfotectônicos. 


\subsubsection{Fator de assimetria}

Com o intuito de complementar a análise de anomalias de drenagem e levantar dados que possibilitem interpretar os lineamentos morfoestruturais, fez-se o cálculo do Fator de Assimetria (FA) considerando-se os rios principais das bacias de drenagem definidas acima. Este fator (Hare \& Gardner 1985; Keller \& Pinter 1996) tem como fundamento primordial, a medida de assimetria, definida pela relação de canais das margens direita e esquerda do rio principal. O FA é calculado pela seguinte fórmula:

$$
F A=100 \times\left(\frac{A d}{A t}\right)
$$

Onde: Ad (área da margem direita da bacia de drenagem; e At (área total da bacia de drenagem).

De forma geral, os dados revelam que as BDRC e BDRP apresentam os maiores valores de assimetria, correspondente a $\mathrm{FA}=62$ e $\mathrm{FA}=71$, respectivamente, uma vez que a área à esquerda desses rios é predominantemente inferior à direita. Já a BDRA é a menos assimétrica de todas, como indicado por valor de $\mathrm{FA}=42$ (Figura 18). Entretanto, esta baixa simetria é aparente, ocorrendo, mais especificamente, nos cursos baixos e médios do rio Arari, enquanto que as margens no alto curso deste rio mostram-se fortemente assimétricas $\mathrm{FA}=84$. 


\subsubsection{Paleocanais}

Feições morfológicas relacionadas a paleocanais são presentes na área de estudo (Figura 29), embora em volume inferior ao verificado em outras áreas da ilha do Marajó, como relatado em vários trabalhos prévios (p.e., Rossetti et al. 2007; Rossetti \& Góes 2008; Rossetti et al. 2008b). Estes são, em geral, contínuos, mas também ocorrem palocanais representados por segmentos isolados, cuja continuidade lateral pode ser facilmente reconstituída dada sua distribuição espacial. A ocorrência de paleocanais é mais significativa no compartimento morfoestrutural II do que no compartimento morfoestrutural I.

Os paleocanais possuem formas alongadas a levemente sinuosas e, localmente meandrantes. Seus comprimentos variam entre 2,5 e $50 \mathrm{~km}$ e as larguras entre $0,5 \mathrm{e}$ aproximadamente $5 \mathrm{~km}$. Anomalias de drenagem também podem ser reconhecidas no sistema de paleodrenagem, o que é principalmente indicado por freqüentes mudanças bruscas na direção dos paleocanais, configurando desvios em ângulo reto (ver círculos na Figura 29), além de meandros isolados e comprimidos.

A determinação do sentido do paleofluxo é problemática, uma vez que os paleocanais não necessariamente fazem parte de um mesmo sistema de drenagem, podendo registrar canais que migraram com o tempo, resultando em um sistema complexo de morfologias sobrepostas. Porém, o sistema de paleocanais dominante na porção central da área de estudo indica paleofluxos com direcionamento principal de $\mathrm{NE}$ para $\mathrm{SW}$, com forte inflexão para N (Figura 29). 


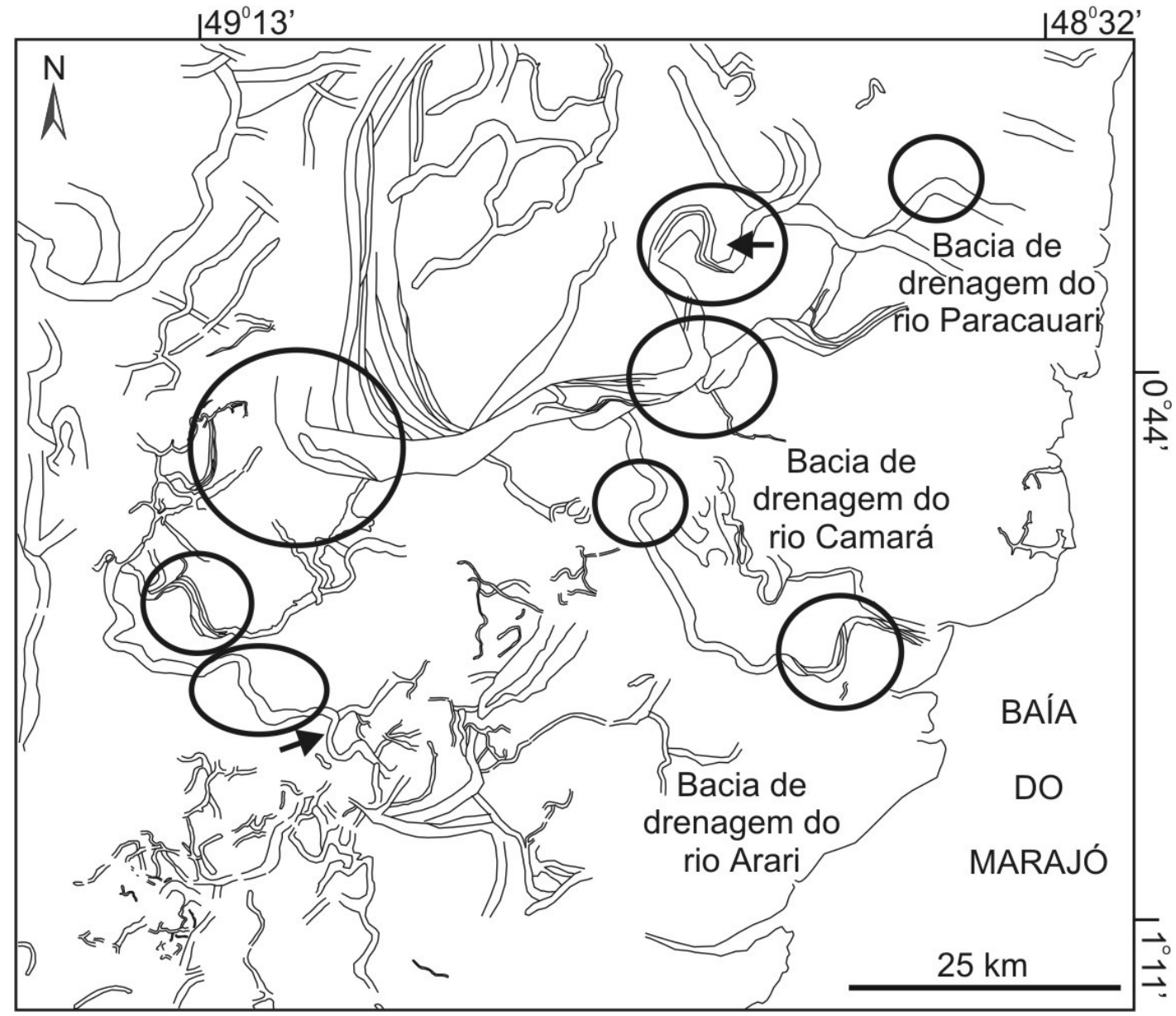

Figura 29 - Mapa de paleocanais derivados da análise visual de imagem Landsat. Círculos indicam locais onde ocorrem rápidos desvios de direção dos paleocanais, configurando ângulos retos. Setas indicam meandros isolados e comprimidos.

\subsection{Sondagem elétrica vertical (SEV)}

A interpretação estratigráfica e litológica dos dados geoelétricos derivados da SEV só foi possível pelo conhecimento geológico prévio da área de estudo. Este foi baseado em informações disponíveis na literatura, adicionados a dados de superfície (i.e., raras exposições ao longo de falésias, pequenas pedreiras e, mais raramente, cortes de estrada) 
coletados ao longo deste estudo. Dada sua importância na interpretação das SEVs, bem como dos dados de GPR a serem apresentados em capítulo subseqüente, faz-se primeiramente uma síntese da geologia na área de estudo.

\subsubsection{Aspectos geológicos relevantes à interpretação dos dados geoelétricos}

A Formação Barreiras aflora em várias pequenas exposições em sua parte leste, onde consiste principalmente em arenitos e argilitos maciços, fortemente intemperizados, e ainda, conglomerados. Estas litologias, que mostram cores variando de branco, amarelo, lilás a vermelho, são localmente endurecidas devido à forte cimentação por óxidos e hidróxidos de ferro. As melhores exposições desta unidade foram registradas ao longo de falésias costeiras nas adjacências da cidade de Salvaterra (Figura 30A-D). Como verificado em muitas outras áreas nos estados do Pará e Maranhão (p.e., Rossetti, 2004), o topo da Formação Barreiras na área de estudo é sistematicamente marcado por discordância com relevo erosional pronunciado de vários metros em escala de afloramento. Isto é acompanhado por colunas verticais de concreções ferruginosas relacionado a paleossolo laterítico de expressão regional. Por vezes, o paleossolo laterítico in situ é ausente, sendo substituído por lag de laterita e seixos de quartzo. Para oeste das falésias costeiras, a Formação Barreiras está exposta ao longo de poucos cortes de estradas e pequenas pedreiras, onde as concreções lateríticas e/ou lag de clastos lateríticos e seixos de quartzo estão presentes (Figura 30E-G).

Onde exposta, a Formação Barreiras, na área de estudo está sobreposta por areias quartzosas de granulometria fina, seleção moderada a alta com pequenos fragmentos dispersos de carvão, que fazem parte dos Sedimentos Pós-Barreiras (Figura 30A-G). Esses 
depósitos, que alcançam até $3 \mathrm{~m}$ de espessura, foram datados por LOE/MAR e exibiram idades do Pleistoceno Tardio e Holoceno (Tatumi et al. 2008). Testemunhos de sondagem adquiridos para oeste da área onde ocorrem as exposições da Formação Barreiras indicaram espessuras mais significativas dos Sedimentos Pós-Barreiras, registrados até a profundidade de 120 m na margem oeste do lago Arari (Miranda et al. 2009; Castro et al. 2010; Rossetti 2010). Estes autores descrevem depósitos heterolíticos, arenosos e argilosos, localmente ricos em matéria orgânica vegetal, com idades radiogênicas variando entre 55.082 $( \pm 12.354){ }^{14} \mathrm{C}$ anos A.P. e a $3.184( \pm 37){ }^{14} \mathrm{C}$ anos A.P. (Figura 31). É importante destacar que não houve registro da Formação Barreiras sob os depósitos quaternários em nenhum dos poços estudados por estes autores. 

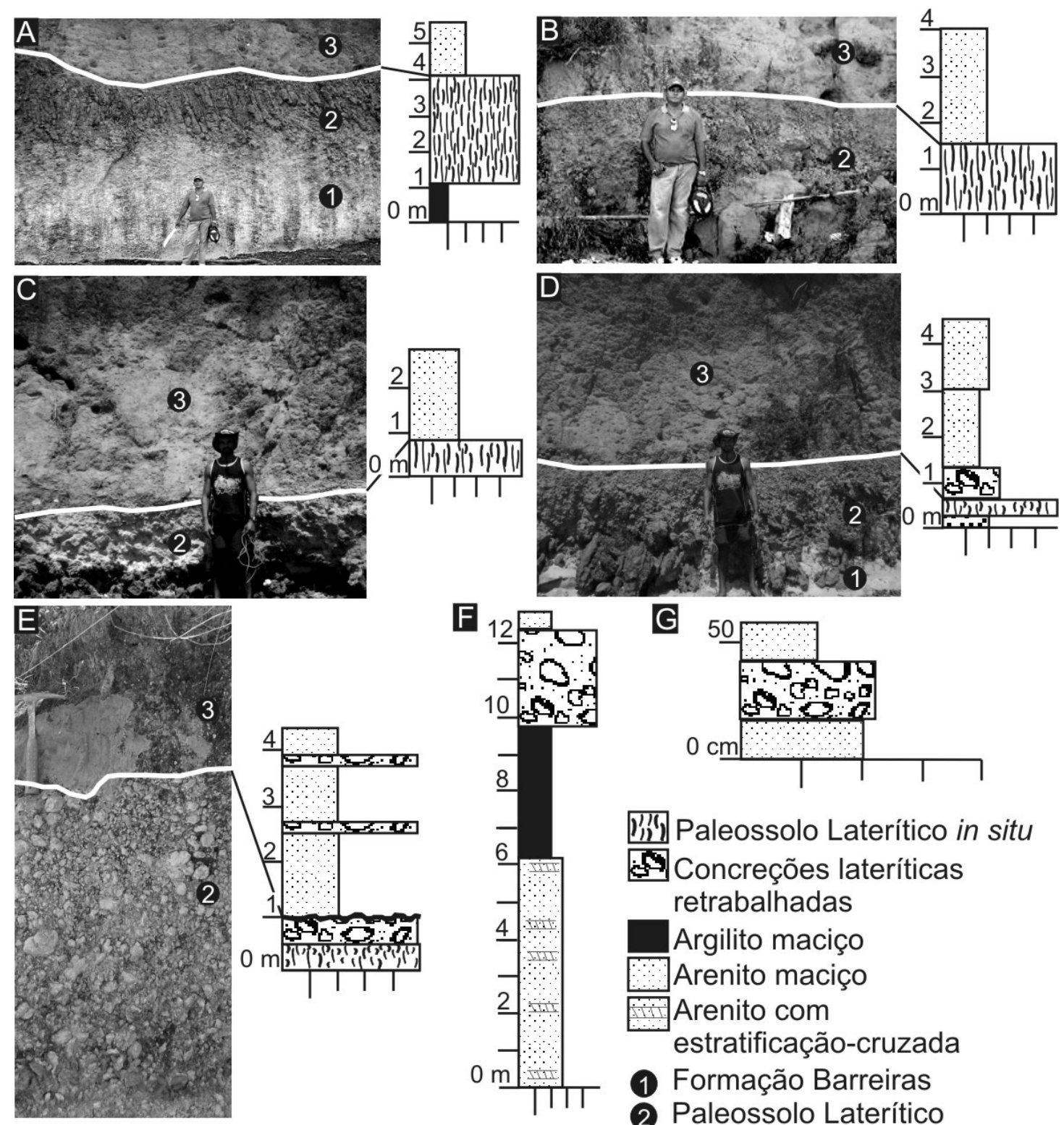

G

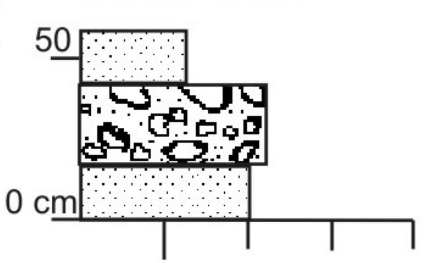

监 Paleossolo Laterítico in situ

S. Concreções lateríticas retrabalhadas

Argilito maciço

Arenito maciço

Arenito com estratificação-cruzada

(1) Formação Barreiras

2 Paleossolo Laterítico

3 Sedimentos Pós-Barreiras Superfície irregular

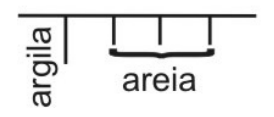

Figura 30 - Exposições da Formação Barreiras em uma falésia costeira na cidade de Salvaterra (A-D, onde SEV 1 a 4 foi adquirida), em um corte de estrada (E, G) e em uma trincheira na porção sudeste dessa cidade $(\mathrm{F})($ martelo $=35 \mathrm{~cm}$ de comprimento). 


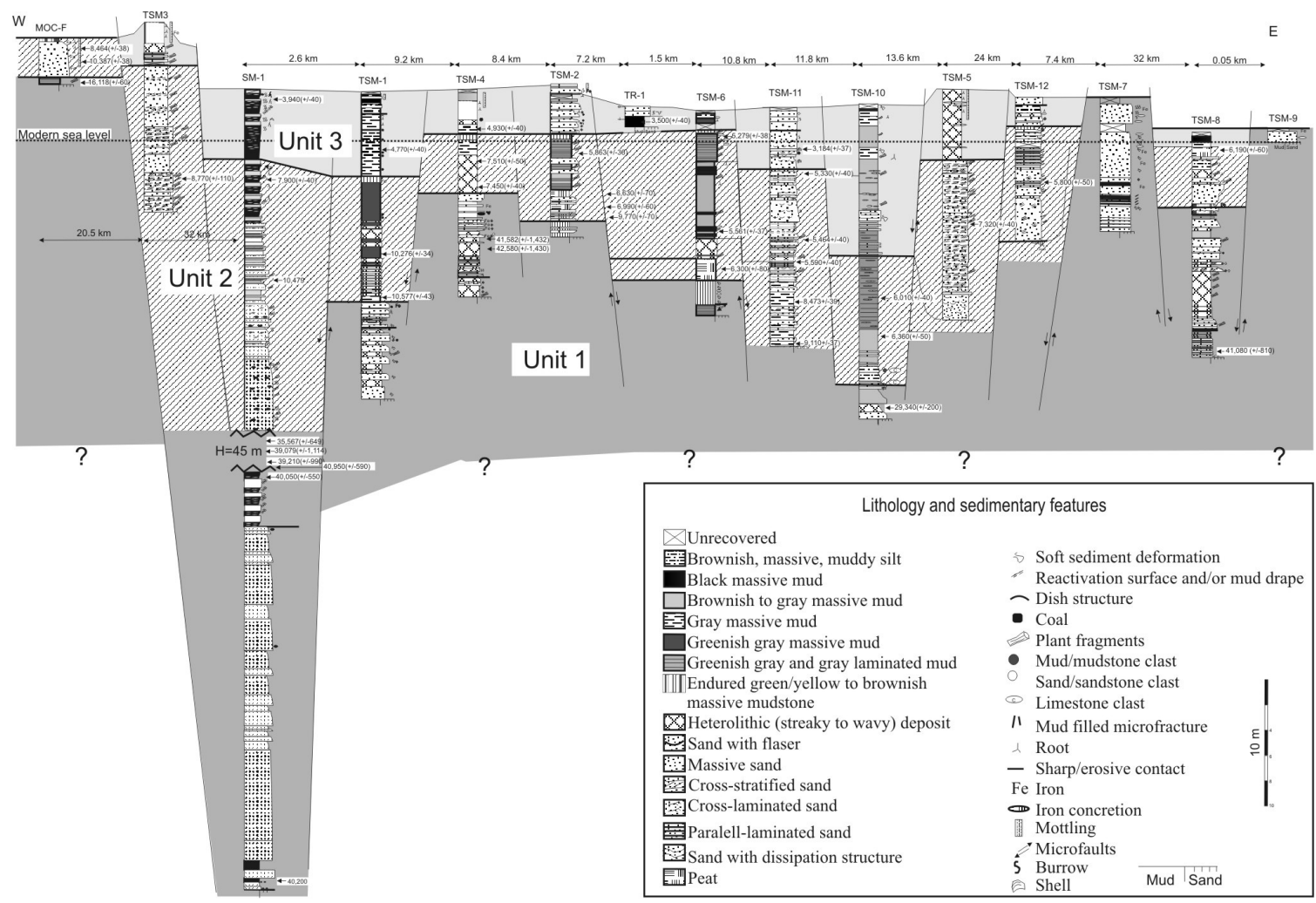

Figura 31 - Perfis litoestratigráficos na ilha do Marajó, com interpretação do arcabouço estratigráfico da sedimentação quaternária tardia (segundo Rossetti, 2010 no prelo).

\subsubsection{Descrição dos dados geoelétricos}

A figura a seguir mostra o mapa de distribuição das sondagens elétricas verticais na ilha do Marajó, isto é, as 21 SEV adquiridas e as 111 derivadas de publicações anteriores (Figura 32). Os dados de campo das $21 \mathrm{SEV}$ são mostrados no Anexo I e as curvas e tabelas de inversão de todas as SEV são observados nos Anexos II e III. 


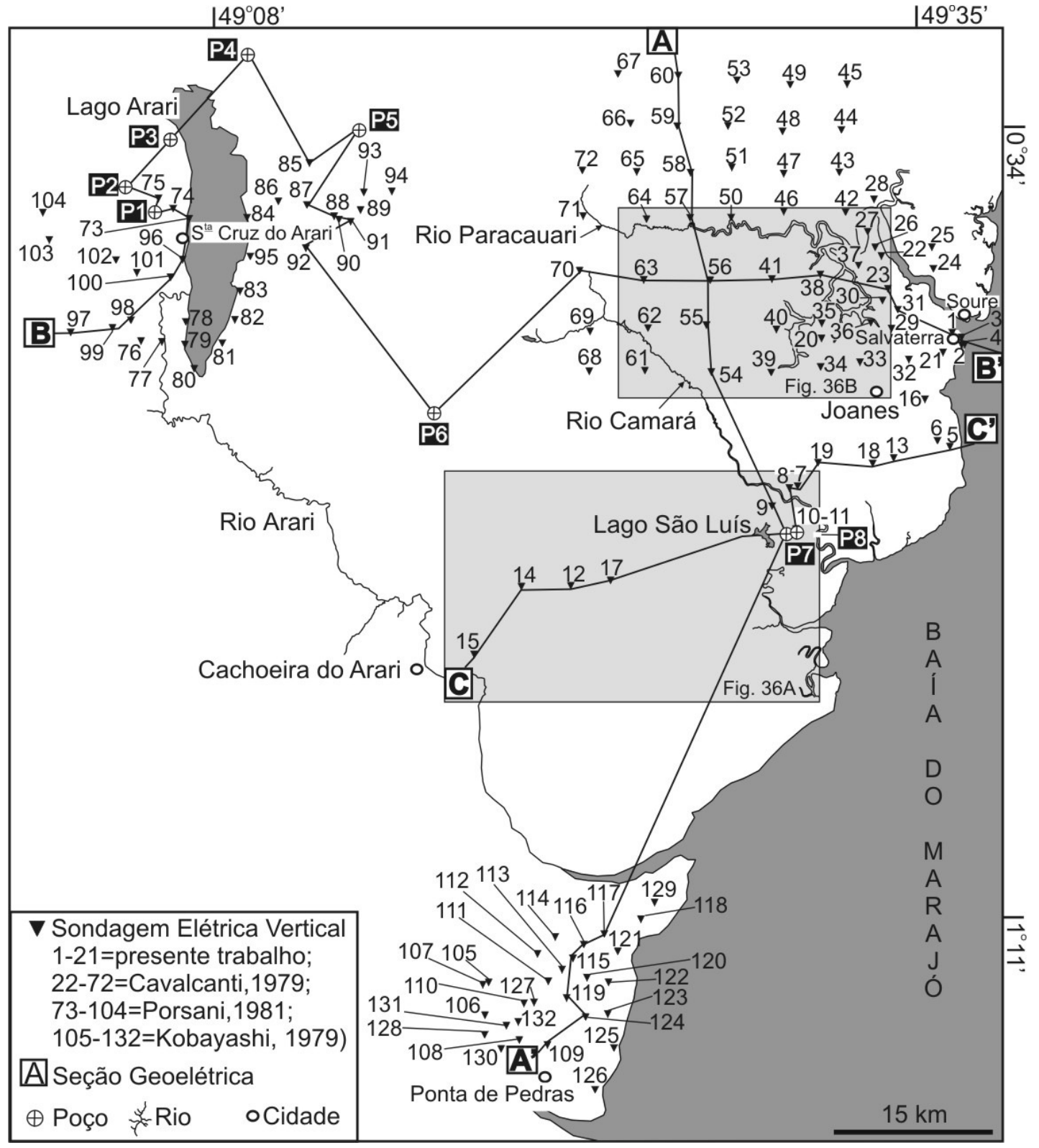

Figura 32 - Mapa com a localização das sondagens elétricas verticais e das seções geológicas mostradas nas figuras 35, 37 e 38. Notar, ainda, a localização dos poços P1 a P8 e da figura 36. 
De forma geral, os valores de resistividade disponíveis para a área estudada variaram de 0,4 a $13.662 \Omega \mathrm{m}$, com concentrações principais entre 50 e $500 \Omega \mathrm{m}$. Levando em consideração as características geológicas conhecidas para a área de estudo (ver item 4), esses dados geoelétricos foram agrupados em 4 categorias relacionadas às seguintes litologias: depósitos heterolíticos (<90 $\Omega \mathrm{m}$ ); areia-argilosa (90 a $200 \Omega \mathrm{m}$ ); areia (200 a $500 \Omega \mathrm{m}$ ); areia ferruginosa e concreções laterita (> $500 \Omega \mathrm{m})$. Os depósitos heterolíticos refletem proporções variadas de camadas de argila intercaladas com areias, em geral finas, mas normalmente com prevalência de argila. O atribuição dos valores mais elevados de resistividade a areias ferruginosas e lateríticas será melhor justificada no item 9.2. A distribuição dos dados geofísicos na área levou ao reconhecimento de que esses últimos valores ocorrem apenas nas zonas nordeste e sudeste da área, principalmente próximo às cidades de Soure, Salvaterra, Joanes e Ponta de Pedras, onde a Formação Barreiras é dominante em superfície (Figura 33). Nessas áreas, camadas contendo volumes variáveis de ferro interpretadas a partir de dados geofísicos alcançaram até $20 \mathrm{~m}$ de espessura. No restante da área estudada, os valores de resistividade muito baixa a moderada ocorrem em associação somente aos depósitos quaternários. 

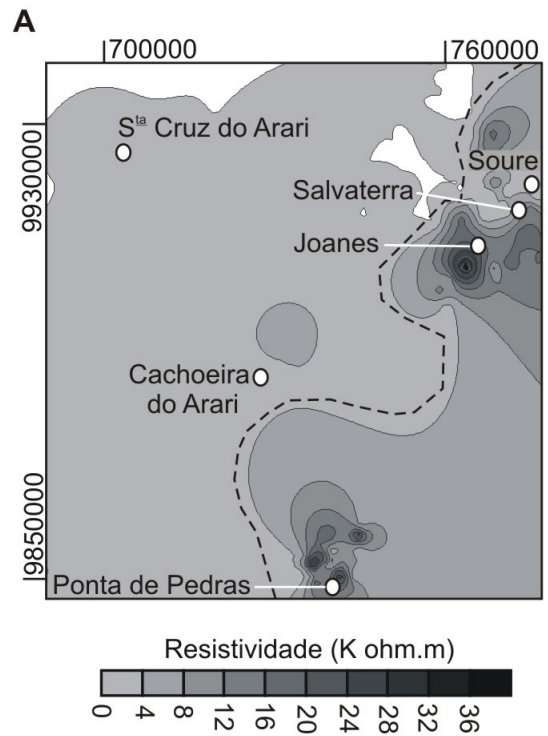
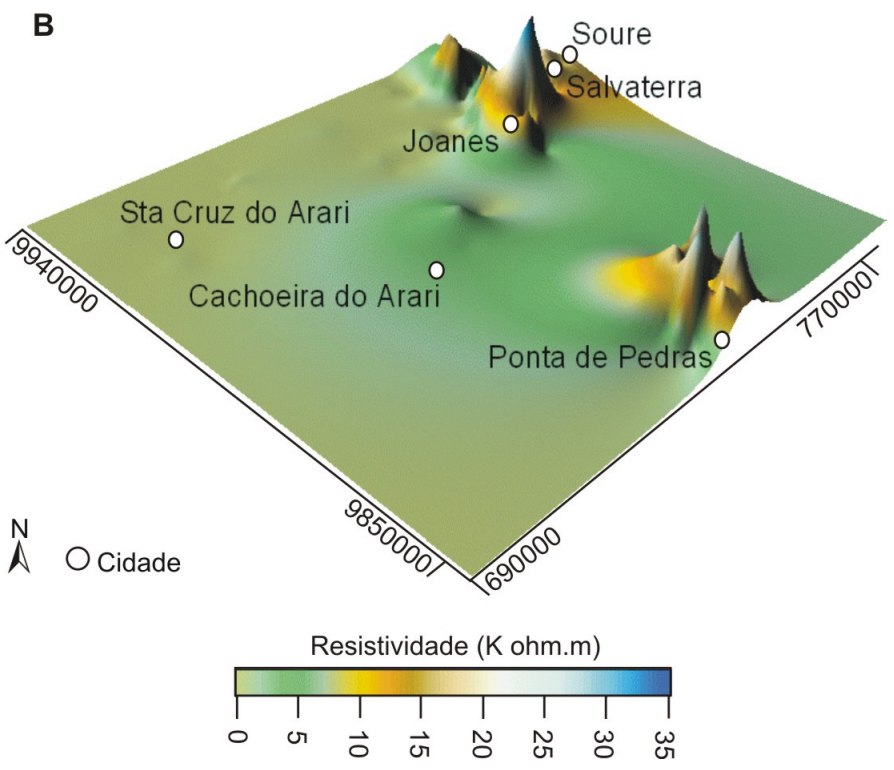

Figura 33 - Mapas de Isópaca (A) e tridimensional (B) baseados nos valores de resistividades (coordenadas em UTM).

A inversão dos dados de SEV levou ao reconhecimento de quatro tipos de curva para a ilha do Marajó.

a) Curva tipo 1 - mostra formas planares quanto mais próximas à superfície, e levemente convexas à medida que aumenta a profundidade (Figura 34A). Essas formas refletem valores altamente resistivos próximos à superfície (i.e., até $10 \mathrm{~m}$ de profundidade), seguido por abrupta diminuição e conseqüente leve aumento em maiores profundidades. Esse tipo de curva foi o único registrado nas áreas com exposições da Formação Barreiras, ou seja, nas porções sudeste e leste da área estudada. Essa curva foi também registrada em 2 perfis de sondagem elétrica (SEV 15 e 14) adquiridas próximo à cidade de Cachoeira do Arari, além de 3 sondagens elétricas (SEV 8 a 10) coletadas próximo ao lago São Luís. 
b) Curva tipo 2 - é caracterizada por forma côncava pronunciada, reflexo dos baixos valores condutivos em superfície rasa que aumentam bruscamente com a profundidade, onde a resistividade estabiliza e, então, aumenta rapidamente (Figura 34B). Esse tipo de curva foi tipicamente registrado na área de entorno do rio Paracauari, sendo também detectada em várias sondagens elétricas nas adjacências do lago Arari. Além disso, esta curva está presente nas SEV 12, SEV 14 e SEV 17, localizadas próximo à cidade de Cachoeira do Arari.

c) Curva tipo 3 - é definida por duas áreas levemente côncavas, separadas por uma área suave a abrupta com convexidade para cima (Figura 34C). Essa forma reflete valores resistivos dominantemente baixos, com dois picos de condutividade ligeiramente mais elevados com a profundidade. A curva tipo 3 prevalece somente na área do lago Arari, embora tenha sido indicada em todas as sondagens elétricas coletadas ao redor do rio Paracauari, exceto aquelas posicionadas muito próximas ao curso do rio (i.e., SEV 22, 23, 26, 27, 42, 46, 50, 57, 64 e 71). Uma variação dessa curva foi somente caracterizada por um único pico côncavo bem definido a profundidades mais altas, sendo registrado nas SEV 87 a 91 na margem leste do lago Arari.

d) Curva tipo 4 - é definida por forma geralmente planar com limite abrupto para a direita, que reflete baixos valores de condutividade a profundidades baixa e moderada, seguida por mudança abrupta ainda menos condutiva a profundidades mais elevadas (Figura 34D). Numerosas sondagens elétricas prospectadas na área do lago Arari registraram esse tipo de curva, com exceção de umas poucas em sua margem leste, ou seja, SEV 87 a 91, onde o tipo modificado da curva tipo 3 foi também documentado. Além disso, curva do tipo 4 foi também registrada nas 
mesmas sondagens elétricas das áreas do entorno do rio Paracauari, onde a curva do tipo 3 estava presente.

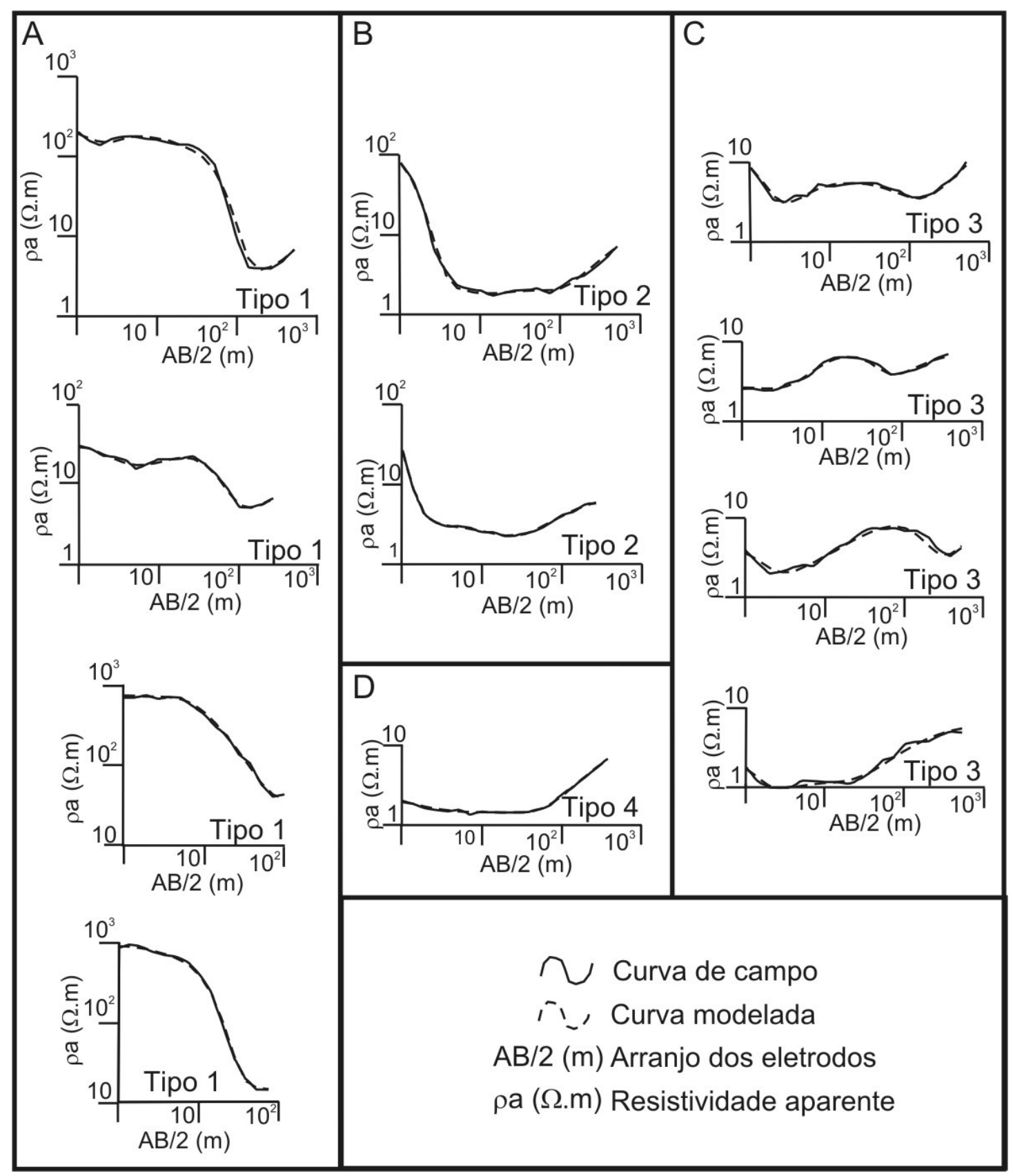

Figura 34 - A-D) Tipos de curvas de resistividade derivadas das sondagens elétricas verticais. 


\subsubsection{Descrição integrada de seções geoelétricas, dados geológicos e geomofológicos}

Três seções geoelétricas (i.e., A-A', B-B' e C-C') foram elaboradas para a área em apreço, as quais são representativas da distribuição dos estratos sedimentares até a profundidade aproximada de $100 \mathrm{~m}$. Estas foram interpretadas com base na integração de dados elétricos, geológicos e morfoestruturais coletados em campo e em imagen Landsat.

A seção A-A' (Figura 35) é representativa de um transecto de $105 \mathrm{~km} \mathrm{de}$ comprimento de direção N-S, o qual intercepta os rios Paracauari e Camará na porção leste da área de estudo, e estende-se até a cidade de Ponta de Pedras em porção sul (Figura 32). Os dados de SEV indicaram que a parte norte dessa seção possui somente valores de resistividade $<90 \Omega \mathrm{m}$, relacionados à prevalência de depósitos heterolíticos. A análise de imagens Landsat revelou que esta parte da seção A-A' se estende por uma extensa área dominada por paleocanais meandrantes representativos da porção fluvial do sistema paleoestuarino formado no Pleistoceno Tardio-Holoceno, como registrado em trabalhos anteriores (p.e., Rossetti et al. 2007; Rossetti et al. 2008a). Por esta razão, esses depósitos heterolíticos são aqui interpretados como pertencentes aos Sedimentos Pós-Barreiras.

Por outro lado, a porção mediana e sul da seção A-A' mostra os mais altos valores de resistividade próximos à superfície. Essa porção da seção ocorre na margem leste da ilha do Marajó, onde se registra amplamente em superfície o paleossolo laterítico característico do topo da Formação Barreiras, bem como litologias cimentadas por ferro relacionadas com este perfil de intemperismo. Portanto, os altos valores de resistividade desta seção são atribuídos a essas ocorrências de material ferruginoso do desta unidade. Consequentemente, baixos valores de resistividade subjacentes a este horizonte altamente resistivo foram 
relacionados a depósitos heterolíticos e arenosos pertencentes à Formação Barreiras. Não se descarta, porém, que em profundidades maiores, parte destes depósitos possa estar incluída em unidades sedimentares mais antigas.

É interessante observar que a passagem lateral entre estratos relacionados à Formação Barreiras e depósitos quaternários tardios, verificada entre as SEVs 9 e 54, ocorre de forma brusca (Figura 35). Vários lineamentos morfoestruturais definidos por drenagens retilíneas e tipicamente ortogonais ocorrem nas adjacências da SEV 9 (ver setas no interior do retângulo maior à direita na figura Figura 36A). Além disto, neste local ocorrem lagos alongados que estão em continuidade lateral com morfologias de paleocanais, sendo um dos mais expressivos o lago São Luís (ver também Figura 24B). Este lago, que também forma segmentos retilíneos e ortogonais, sofre forte inflexão para nordeste, estando em continuidade com lineamento de direção NE-SW na margem esquerda do rio Camará (ver setas amarelas no interior do retângulo maior à direita na Figura 36A).

A análise de dois testemunhos de sondagem imediatamente a sudeste da SEV 9 (ver P7 e P8 nas figuras 32 e 35) registrou $18 \mathrm{~m}$ de depósitos com idades de até $41.080( \pm 810)$ ${ }^{14} \mathrm{C}$ anos A.P. (P7) em contato brusco com a Formação Barreiras (P8). 


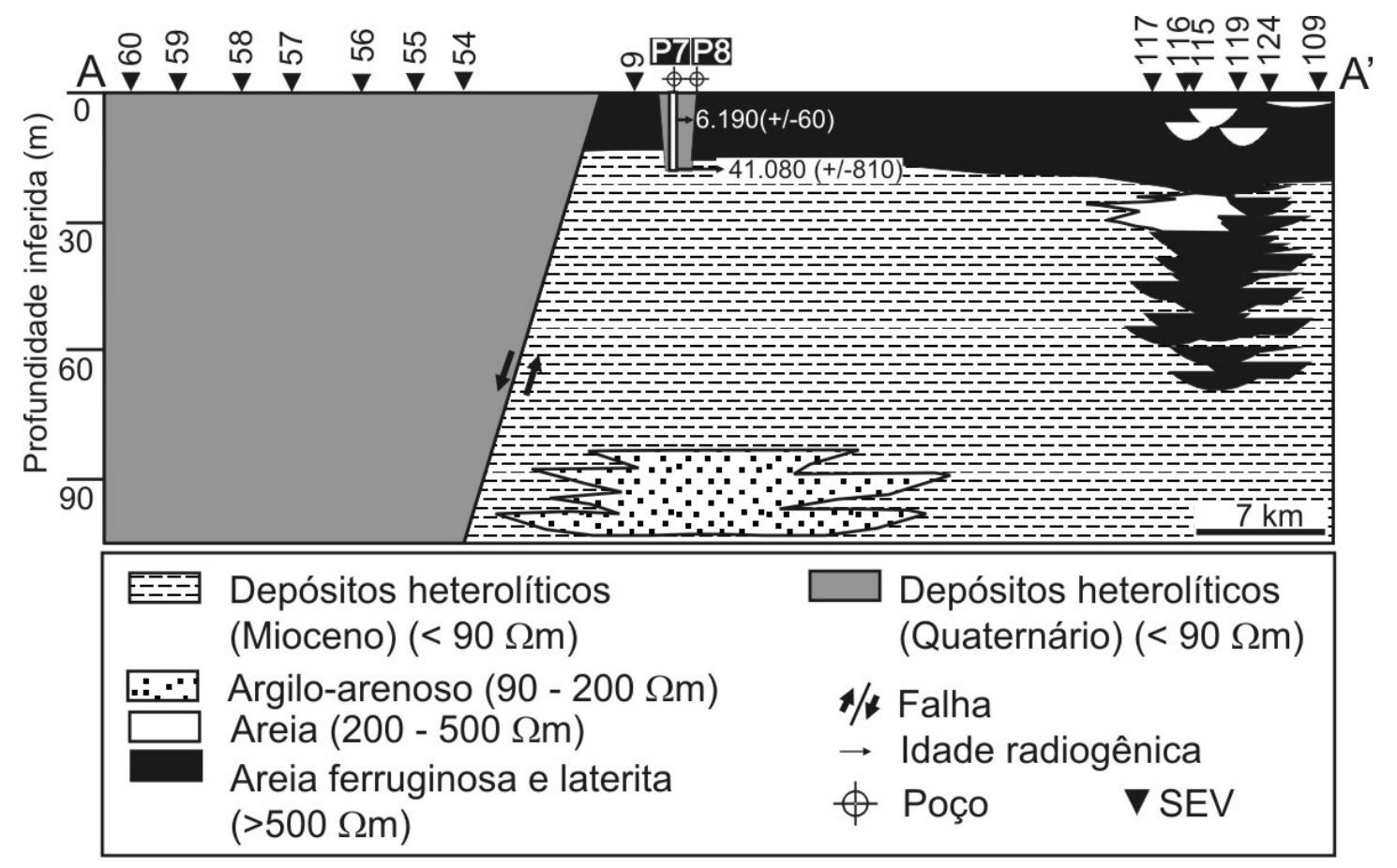

Figura 35 - Seção geoelétrica A-A', interpretada a partir da integração de dados SEV com testemunhos de sondagem (ver localização na figura 32). 

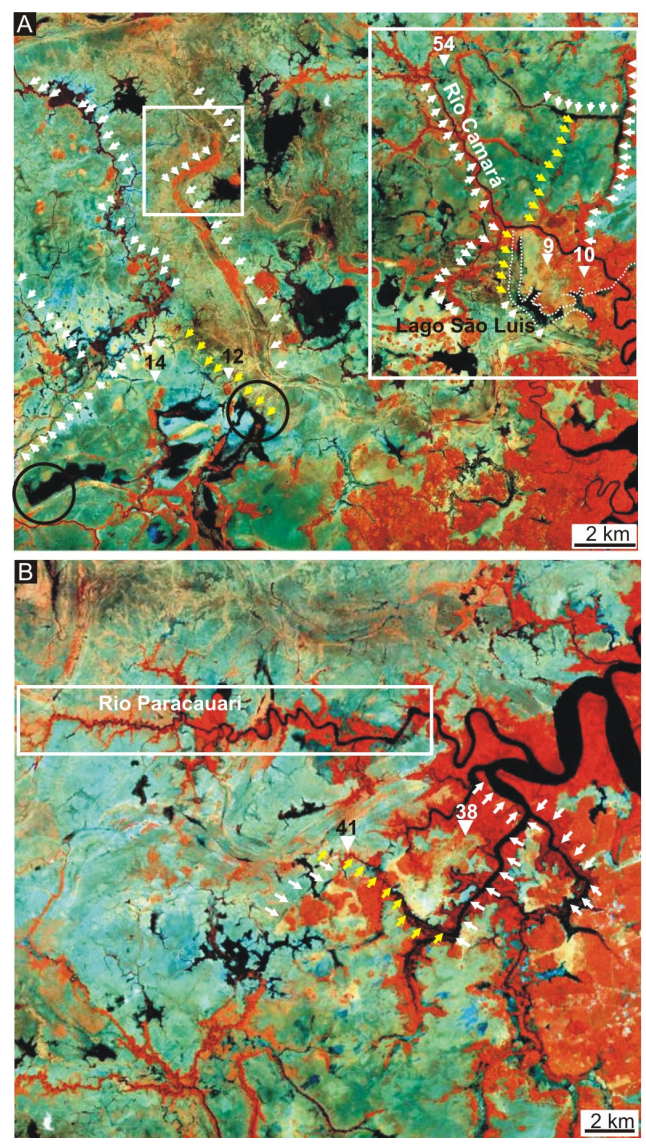

Figura 36 - Imagens Landasat (ver figura 32 para localização) ilustrando os lineamentos morfoestruturais que coincidem com as falhas (setas amarelas) mostradas nas seções A-A' (A), B-B' (B) e C-C' (A) ilustrada nas figuras 35, 37 e 38, respectivamente. Notar que vários outros lineamentos retilíneos que se interceptam mutuamente em ângulos retos (setas brancas). Os retângulos em A situam a área com a falha mostrada na seção A-A', e o paleocanal do Quaternário Superior-Holoceno descritos em associação com a seção C-C', respectivamente. Círculos nessa figura indicam áreas de lagos limitado abruptamente. Os retângulos em B indicam onde o rio Paracauari mostra várias inflexões para $90^{\circ} \mathrm{em} \mathrm{seu}$ curso. Ver texto para maiores explicações (vermelho=floresta; verde amarelado ou azul=campo; preto=água; números=perfis de SEV). 
A seção B-B' (Figura 37) é representativa de um transecto que se estende de leste para oeste ao longo de $150 \mathrm{~km}$ de comprimento a norte da área pesquisada. Esta seção intercepta o lago Arari e a bacia hidrográfica do rio Paracauari a leste e oeste, respectivamente (Figura 32). Grande parte desta seção é constituída por valores de resistividade $<90 \Omega \mathrm{m}$. A integração dessa informação com vinte datações de ${ }^{14} \mathrm{C}$ derivadas de seis poços (i.e., P1 a P6) coletados em profundidades variáveis de 11 a 124 m indicou que esses são depósitos quaternários formados entre $42.580( \pm 1.430){ }^{14} \mathrm{C}$ anos A.P. e 3.940 $( \pm 40){ }^{14} \mathrm{C}$ anos A.P. (Rossetti, 2010). Por outro lado, no extremo leste dessa seção foram registrados valores de resistividade elevados próximos à superfície, que são comparáveis aos relacionados às camadas ferruginosas do topo da Formação Barreiras documentadas na porção sul da seção A-A'. Portanto, similarmente atribui-se os depósitos do extremo leste da seção B-B' à Formação Barreiras. Adicionalmente, subjacente às camadas de condutividade elevada ocorre volume amplo de depósitos heterolíticos $(<90 \Omega \mathrm{m})$, bem como areno-argilosos (90-200 $\Omega \mathrm{m})$ e arenosos $(200-500 \Omega \mathrm{m})$, os quais, por relacionamento estratigráfico, foram também vinculados a essa unidade.

A passagem entre depósitos quaternários tardios e a Formação Barreiras no extremo leste da seção B-B' ocorre de forma abrupta dentro de uma distância inferior a $5 \mathrm{~km}$. É marcante que esta passagem brusca coincide com local onde um dos tributários principais do rio Paracauari sofre várias inflexões bruscas, formando segmentos retilíneos e fortemente ortogonais, caracterizando drenagem tipicamente retangular (ver setas na Figura 36B). Em particular, imediatamente a leste da SEV 41 ocorre um dos lados de um grande retângulo formado por canal retilíneo de direção NW-SE (setas amarelas na Figura 36B). Adicionalmente, um extenso segmento do próprio rio Paracauari imediatamente a nordeste 
desse retângulo, possui várias anomalias de drenagem, representadas por trechos retilíneos e ortogonais que mudam bruscamente para canal fortemente meandrante (retângulo na figura 36B). 


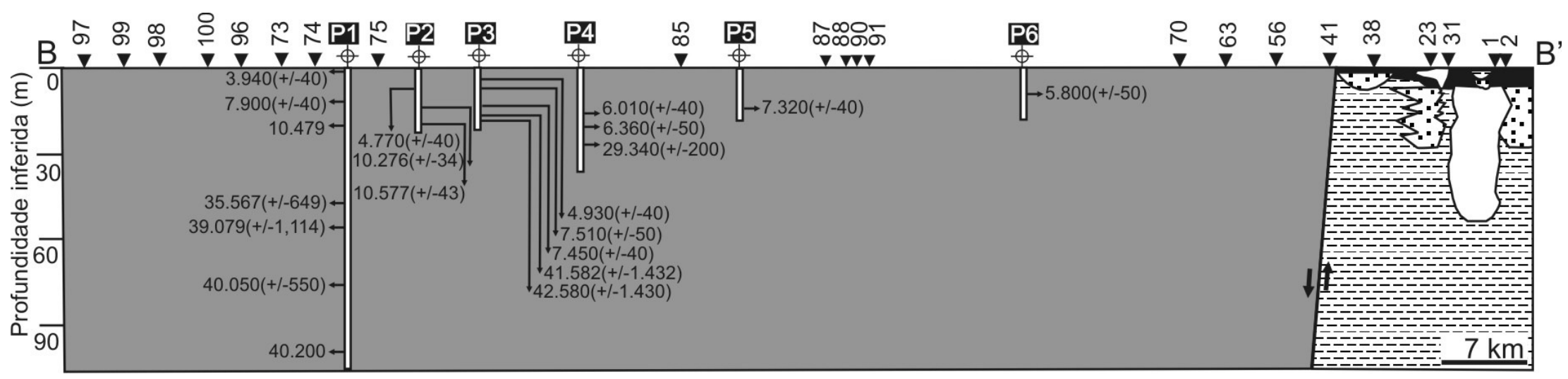

Figura 37 - Seção geoelétrica interpretada a partir de SEV integradas com dados de testemunhos de sondagem ao longo do transecto

B-B' (ver figura 32 para localização e figura 35 para legenda). Falhas indicadas nesta seção coincidem com um lineamento

morfoestrutural marcado pelo curso de um rio mostrado na imagem Landsat observada na figura 36B. 
A seção C-C'(Figura 38) é a menos extensa, compreendendo um transecto inferior a $60 \mathrm{~km}$ de comprimento direcionado aproximadamente de NE para SW. Esta seção, que conecta as sondagens elétricas localizadas nas adjacências das cidades de Cachoeira do Arari e Joanes, intercepta a seção A-A’ próximo ao lago São Luís (Figura 32). Os valores de resistividade são distribuídos de forma mais variável nesta seção relativamente às demais descritas anteriormente. Assim, ambos os extremos da seção C-C' mostram valores de resistividade alta até a profundidade de aproximadamente $30 \mathrm{~m}$, que são similares àqueles relacionados com o paleossolo laterítico e/ou camadas ferruginosas da Formação Barreiras registrado nas seções A-A' e B-B'. Estes horizontes altamente resistivos recobrem, a nordeste, litologias variando de heterolíticas $(<90 \Omega \mathrm{m})$, areno-argilosas $(90$ $200 \Omega \mathrm{m})$ a arenosas (200-500 $\Omega \mathrm{m})$, e a sudoeste depósitos dominantemente heterolíticos (< $90 \Omega \mathrm{m})$ com ocorrências subordinadas de arenito $(200-500 \Omega \mathrm{m})$.

Por outro lado, a zona mediana da seção C-C' consiste integralmente em depósitos heterolíticos $(<90 \Omega \mathrm{m})$. Datação radiogênica ${ }^{14} \mathrm{C}$ de amostras coletadas a partir de testemunho de sondagem derivado deste intervalo litológico indicou idade de até 42.080 $( \pm 810){ }^{14} \mathrm{C}$ anos A.P. (P7 na figura 38$)$. Similarmente às outras seções, essas argilas quaternárias tardias e holocenas estão em contato lateral abrupto com as demais litologias relacionadas à Formação Barreiras em ambos os extremos desta seção.

O contato brusco entre depósitos quaternários e a Formação Barreiras que ocorre na porção oeste da seção C-C' possui equivalência com lineamento morfoestrutural de direção NW-SE (ver setas amarelas fora dos retângulos da figura 36A). Este lineamento, que define margem retilínea de lagos alongados sugestivos do bloqueio de antiga drenagem, forma padrão fortemente ortogonal com vários outros lineamentos morfoestruturais definidos por 
drenagens retilíneas deste setor (setas brancas fora dos retângulos da figura 36A). Por outro lado, o contato entre depósitos quaternários e a Formação Barreiras no extremo leste da seção C-C' representa o único que não pode ser relacionado com nenhum lineamento em particular. É interessante observar que o terreno compreendido entre as SEV 12 e pouco a oeste da SEV 10 contém uma abundância de paleocanais, sendo que o mais expressivo e contínuo deles ocorre nas proximidades da SEV 12, onde forma com trechos perfeitamente ortogonais que paralelizam os lineamentos morfoestruturais do extremo oeste dessa seção. Uma abundância de lagos de dimensões variadas concentra-se entre este paleocanal e o rio Camará (Figura 36A).

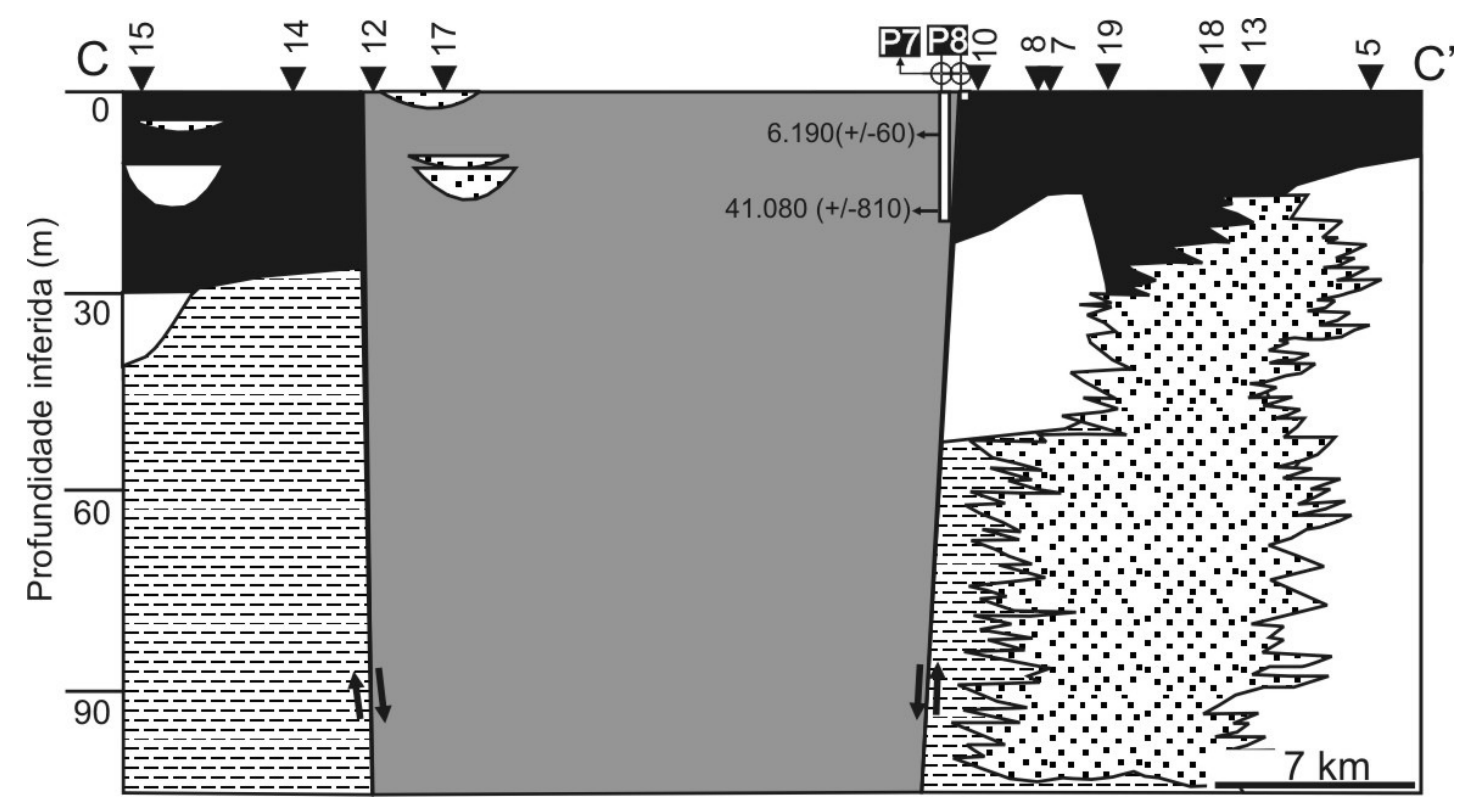

Figura 38 - Seção geoelétrica interpretada a partir de sondagens elétricas verticais

integradas a dados de testemunhos de sondagem ao longo do transecto C-C' (ver figura 32 para localização e figura 35 para legenda). As falhas indicadas nesta seção coincidem com o lineamento morfoestrutural marcado pelo curso de um rio mostrado na imagem Landsat observado na figura 36A. 


\subsection{Radar de penetração no solo}

Os dados de GPR adquiridos na área de estudo somam aproximadamente $16 \mathrm{~km} \mathrm{em}$ linha reta (Figura 39). A interpretação estratigráfica e litológica dessas seções (Figuras 4048) só foi possível pelo conhecimento geológico prévio da área, construído pela integração de dados de subsuperfície geradas por sondagem elétrica vertical com informações de superfície (i.e., raras exposições ao longo de falésias, pequenas pedreiras e, mais raramente, cortes de estrada, além de testemunhos de sondagem), como previamente descritos no item 8.2.1. e ilustradas na figuras 30 e na figura de testemunhos de sondagem (Figura 31). Além destas informações, foram verificados vários locais onde o horizonte laterítico do topo da Formação Barreiras ocorre a apenas 1 ou $2 \mathrm{~m}$ abaixo da superfície (p.e., final a nordeste e sudeste das seções apresentadas nas figuras 45 e 46, respectivamente, e início a sudeste da seção apresentada na figura 43), o que permitiu relacionar as reflexões contínuas e de alta freqüência do topo da unidade A descrita abaixo com a discordância com paleossolo laterítico do topo da Formação Barreiras (ver item 9 para discussões). Esses dados foram fundamentais no entendimento do significado geológico das reflexões, permitindo analisar a continuidade dos estratos em subsuperfície rasa e, com isto, auxiliar no registro de estruturas tectônicas. Infelizmente, não foi possível fazer quaisquer relacionamentos de lineamentos morfoestruturais com estruturas tectônicas sugeridas nas seções de GPR, uma vez que as seções foram adquiridas ao longo de transectos que não interceptaram lineamentos expressivos na imagem Landsat. Isto decorre do fato das seções GPR terem sido adquiridas somente em áreas planas dispostas ao longo de estradas, onde foi possível o acesso do equipamento, o que não coincidiu com os locais dos lineamentos. Embora não tenha sido possível mostrar a correspondência entre lineamentos e seções GPR, estes dados 
foram importantes para revelar deslocamentos de camadas de baixo rejeito, que podem estar relacionadas a estruturas presentes em associação aos lineamentos morfoestruturais de maior escala.

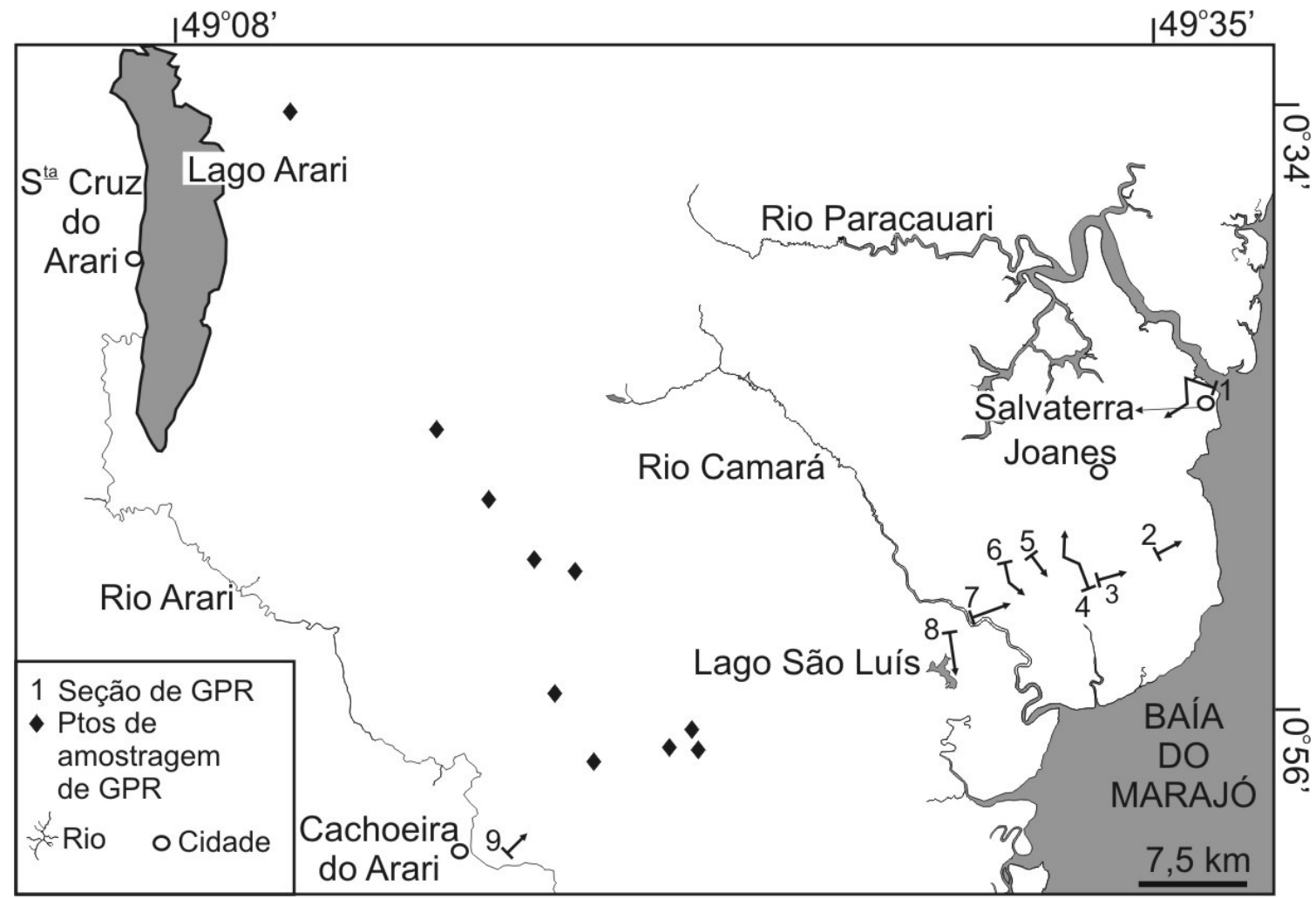

Figura 39 - Mapa de localização dos dados de GPR.

De modo geral, as seções de radar registraram os depósitos sedimentares de interesse para esta pesquisa até a profundidade de, no máximo, 150 ns. De acordo com estimativas geradas automaticamente pelo aplicativo RADAN 6.0, este valor corresponde a aproximadamente $15 \mathrm{~m}$ de profundidade. Estas estimativas de profundidade foram testadas em áreas de falésias, onde os estratos sedimentares acham-se bem expostos. O resultado revelou concordância dos valores estimados com as profundidades reais de marcos estratigráficos de fácil correlação nas seções de radar. Tendo em vista este fato, as seções 
de radar são apresentadas com os valores de profundidade em ns, acompanhados das profundidades estimadas automaticamente pelo aplicativo utilizado.

De maneira geral, duas unidades de radar principais foram amplamente reconhecidas em aproximadamente 50\% das seções adquiridas na área de estudo. Destas, com exceção da seção 9 localizada imediatamente a leste da cidade de Cachoeira de Arari, todas as demais ocorrem entre a costa e o lago São Luís (Figura 39). A outra metade das seções amostradas foram adquiridas em posição intermediária entre este lago e a seção 9, estando distribuídas ao longo de cinturão alongado que se estende de sudeste para noroeste até a margem leste do lago Arari (Figura 39). Todas essas seções mostraram sinal de radar homogeneamente distribuídos de forma contínua e horizontal da base até o topo, não sendo possível a discriminação de padrões ou unidades internas (Figura 49). Portanto, elas não estão incluídas na descrição de unidades de radar abaixo.

\subsubsection{Unidade A}

A unidade A ocorre na base das seções de radar, mostrando espessuras estimadas variáveis entre 6 e 12 m, sendo que sua base não foi registrada na profundidade amostrada de até 15 m, máxima atingida com antena de $200 \mathrm{Mhz}$ utilizada. O topo desta unidade é tipicamente irregular, sendo marcado por um conjunto de reflexões de altas freqüência e amplitude, as quais se destacam fortemente em todas as seções de radar, podendo ser salientadas por outras reflexões de configuração hiperbólica. Estas reflexões se caracterizam, ainda, por truncar reflexões subjacentes e apresentar reflexões sobrepostas que termina em onlap ou downlap, definindo superfície estratigráfica chave relacionada com parada de sedimentação e/ou erosão. É interessante notar que além de reflexões 
hiperbólicas, esta superfície é, com frequência, sobreposta por intervalos de alguns metros onde dominam reflexões caóticas, ou seja, caracterizadas por segmentos descontínuos, de disposição aleatória, os quais mostram baixas amplitude e continuidade lateral. Geograficamente, esta superfície mostra-se com relevo, em geral, irregular, sendo caracterizada por segmentos interrompidos e deslocados verticalmente formando gradientes de até $7 \mathrm{~m}$ (Figura 50). Embora este padrão irregular seja comum a todas as seções, deslocamentos verticais mais significativos foram observados na seção 3 (Figura 48) e em vários setores das seções 1, 2, 4, 5, 7 e 8 (Figuras 40, 47, 43, 44, 46 e 47). Essas áreas com segmentos deslocados são lateralmente limitadas por áreas delgadas formando alinhamentos verticais ou sub-verticais onde não ocorrem reflexões ou onde as reflexões são caóticas (Figura 43A, B). Estes alinhamentos se projetam para cima, afetando os refletores fortes do topo da unidade A e também afetando reflexões da unidade B sobrejacente. Localmente, ocorrem sucessões de segmentos desta superfície com distribuição escalonada caracterizada por segmentos inclinados e progressivamente mais rebaixados em uma determinada direção (Figuras 41C, D, 48A, B).

Internamente à unidade $\mathrm{A}$, verificam-se reflexões com configurações e geometrias diversas. Assim, além de reflexões caóticas, acima definidas, ocorrem proporções variadas de reflexões dos tipos paralelas a sub-paralelas, côncavas e divergentes Reflexões paralelas a subparalelas correspondem a uma série de reflexões concordantes, de alta amplitude e continuidade lateral modera a alta, dispostas horizontalmente formando conjuntos tabulares suavemente ondulantes. Reflexões côncavas ocorrem em áreas localizadas das seções, em geral se estendo lateralmente por alguns metros ou dezenas de metros. Estas reflexões, de amplitude moderada, forma concavidades que interceptam bruscamente reflexões sobrejacentes e são sobrepostas por reflexões que podem ser ou concordantes ou 
discordantes com as reflexões que definem este padrão. Reflexões divergentes formam conjuntos localizados de reflexões inclinadas (ângulos $<30^{\circ}$ ), que são interceptadas bruscamente por outras reflexões sobrejacentes e terminam em onlap ou downlap contra reflexões subjacentes. Lateralmente, estas reflexões divergentes intergradam com as demais reflexões descritas acima (Figura 50).

Além das reflexões acima referidas, que são contidas em outras reflexões com disposição, em geral, planar, a base da unidade A em várias das seções estudadas contém conjuntos de reflexões fortemente ondulantes que caracterizam pacotes com geometrias em mound, que podem ser internamente compostos por conjuntos de reflexões alternadamente côncavas e convexas (Figura 50). Lateralmente, estes conjuntos, aqui designados de subunidade A1 para diferenciar dos intervalos de reflexões sobrejacentes referidos como subunidade A2 na presente tese, podem desaparecer de maneira abrupta. A sub-unidade A1 ocorre em profundidades estimadas variáveis, em geral abaixo de $6 \mathrm{~m}$. Internamente, o pacote com reflexões ondulantes pode conter reflexões truncantes. Estes pacotes são delimitados, em seu topo, por reflexões de altas freqüência e amplitude e de continuidade lateral moderada. Os conjuntos de reflexões ondulantes são bem salientados nas seções de GPR por estarem em descontinuidade com as reflexões sobrejacentes, as quais mostram geralmente terminações em onlap contra sua superfície de topo. A não observação deste pacote de reflexões ondulantes na base da Unidade A pode estar relacionada com sua ausência ou com a falta de sinal de radar, já que as bases das seções estão próximas do limite de profundidade permitida pela freqüência da antena utilizada. 


\subsubsection{Unidade B}

A unidade B, que ocorre sistematicamente sobreposta à unidade $\mathrm{A}$ em todas as seções estudadas, possui espessuras estimadas variando entre $1 \mathrm{~m}$ e $10 \mathrm{~m}$. Embora a distribuição de espessuras desta unidade seja variável na área de estudo, pode-se notar que os menores valores estão concentrados nas seções localizadas entre o lago São Luís e sudeste de Joanes.

A unidade B se destaca da unidade subjacente não só pela presença de marco estratigráfico indicado pelas reflexões de altas frequiências e amplitudes já descritas acima, mas também por apresentar internamente conjuntos de reflexões com configurações bem definidas, em geral dos tipos sub-paralelas e, mais raramente paralelas. Ocasionalmente, estar reflexões são interceptadas por reflexões côncavas de baixa amplitude, que se estendem lateralmente por várias dezenas de metros. Reflexões caóticas ocorrem localmente, embora em pequena proporção relativamente às demais reflexões.

Próximas da base, as reflexões que compões a unidade B são de freqüência baixa, formando grande contraste com as reflexões de alta freqüência que caracterizam o topo da unidade A. Além disto, é importante salientar que essas reflexões de topo são sobrepostas por reflexões da unidade A que terminam formando, com freqüência, relações de onlap e downlap. 

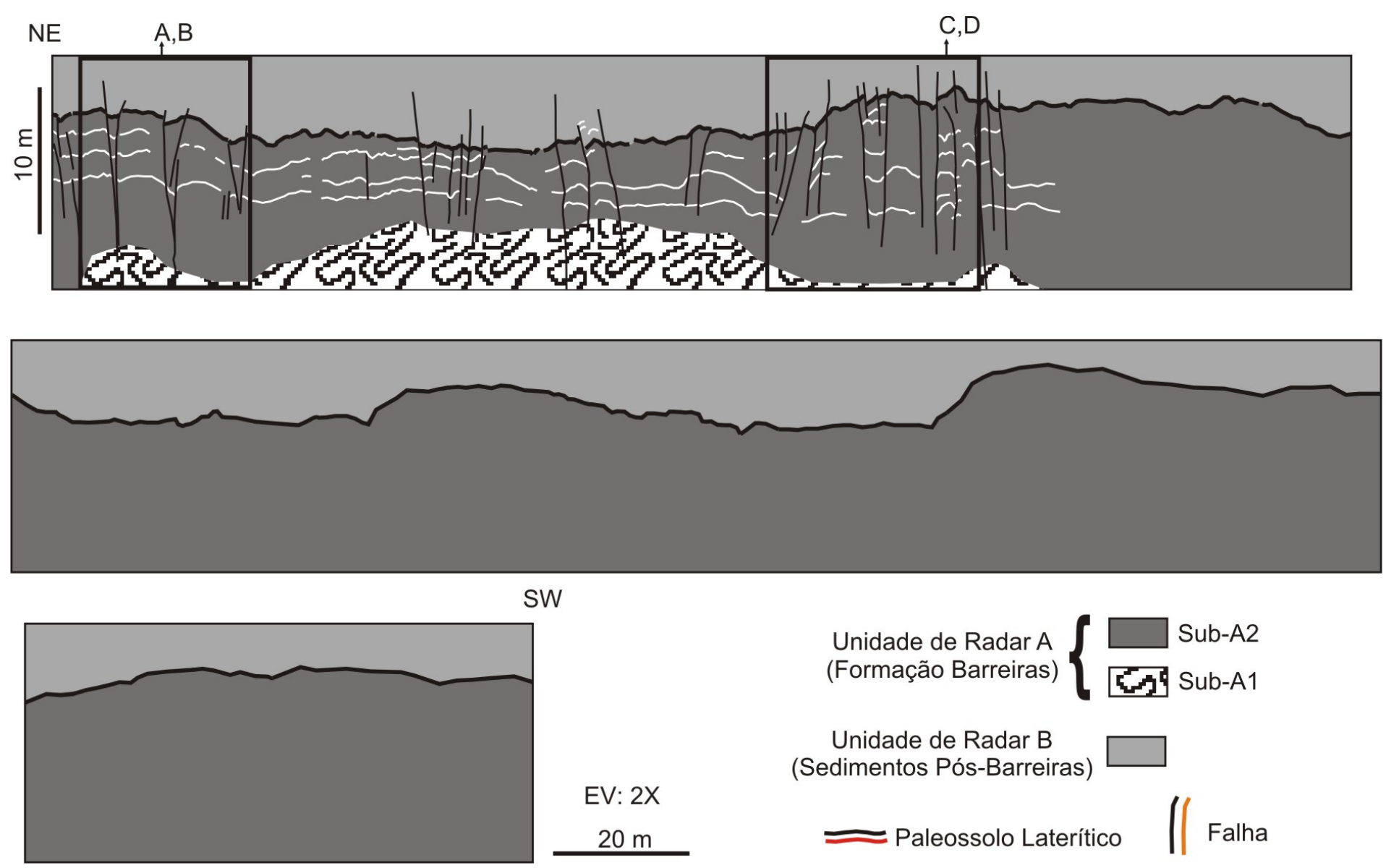

Figura 40 - Seção de radar 1 na área urbana da cidade de Salvaterra (ver localização na figura 39). Notar que as letras A e C mostram a imagem de radar processada, e as B e D indicam a interpretação. 
$\varepsilon$
$\stackrel{n}{\leftarrow}$

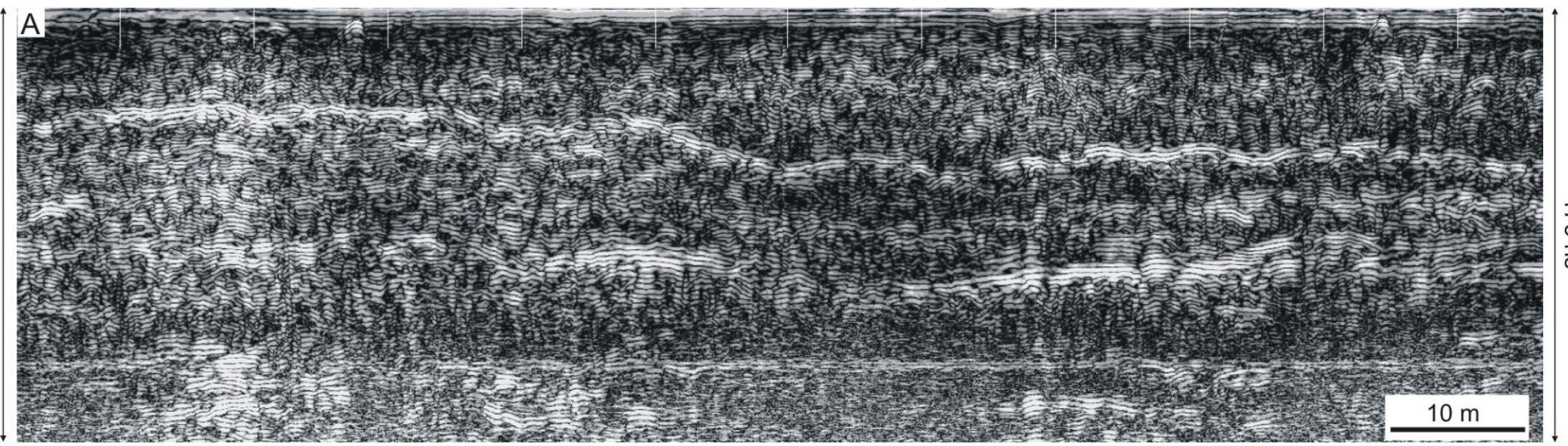

เ

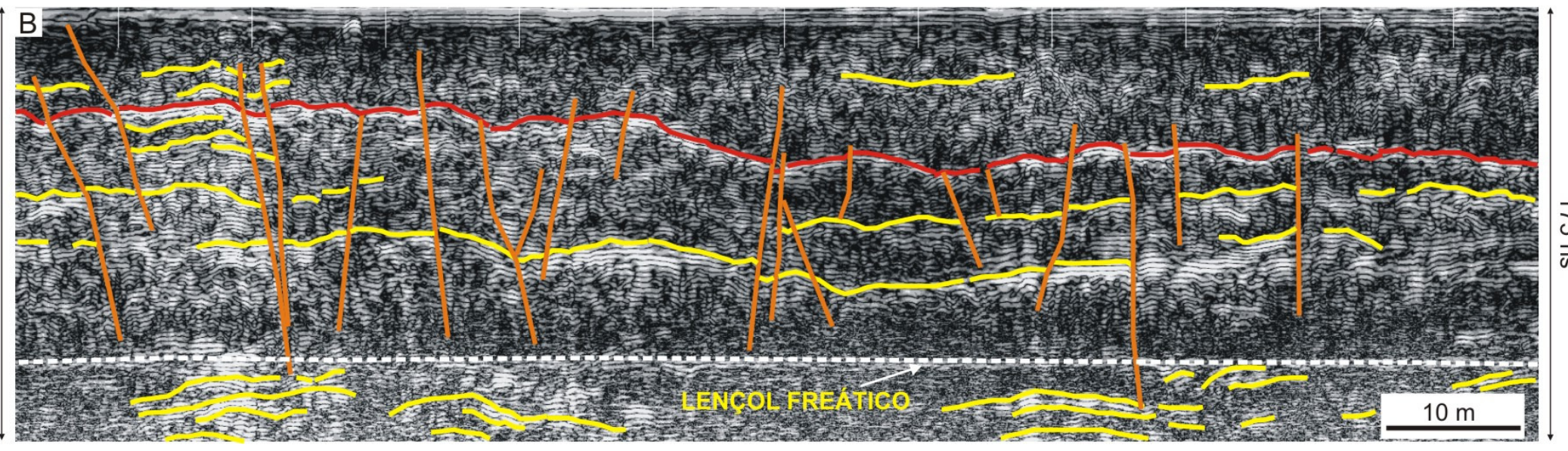

Figura 40 - Continuação. 


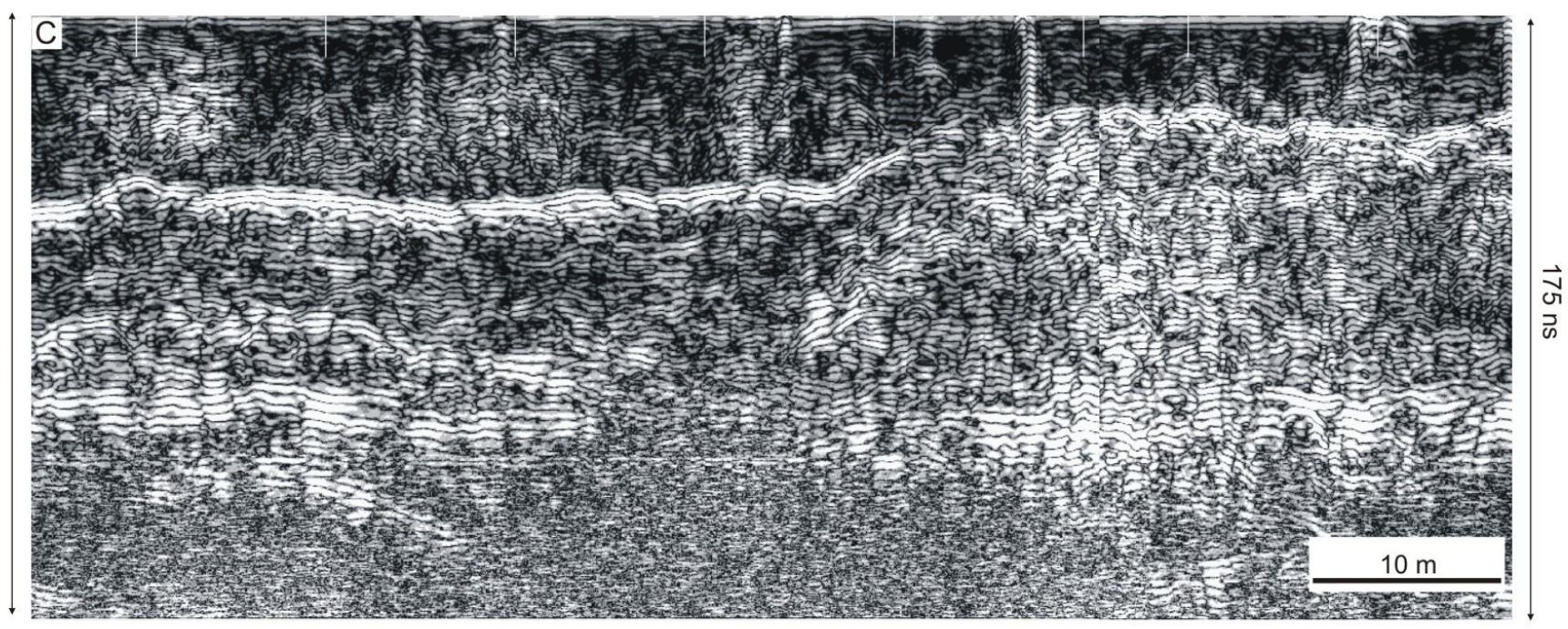

$\varepsilon$

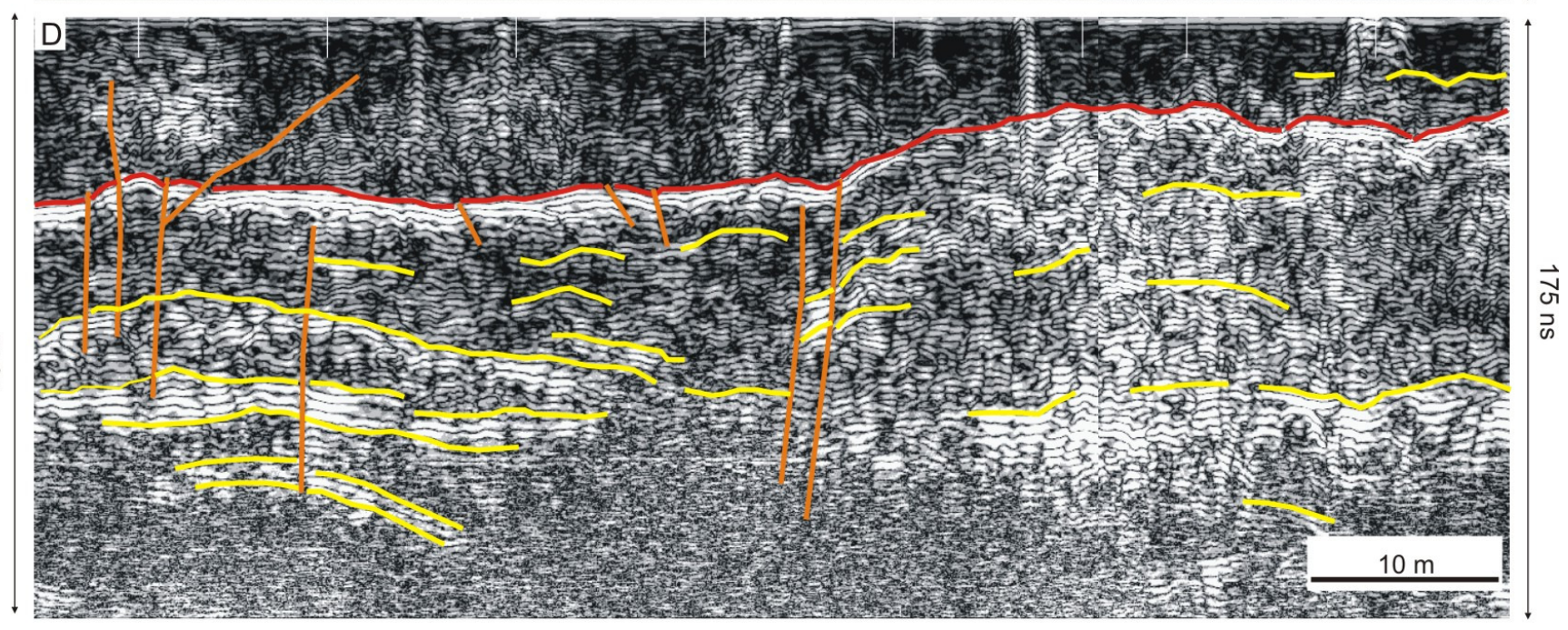

Figura 40 - Continuação. 


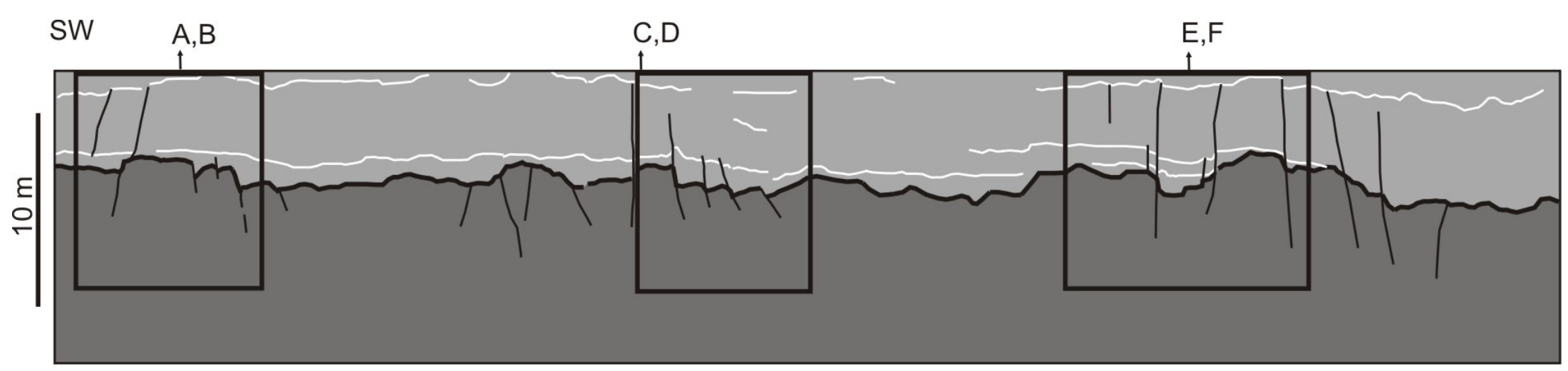

NE

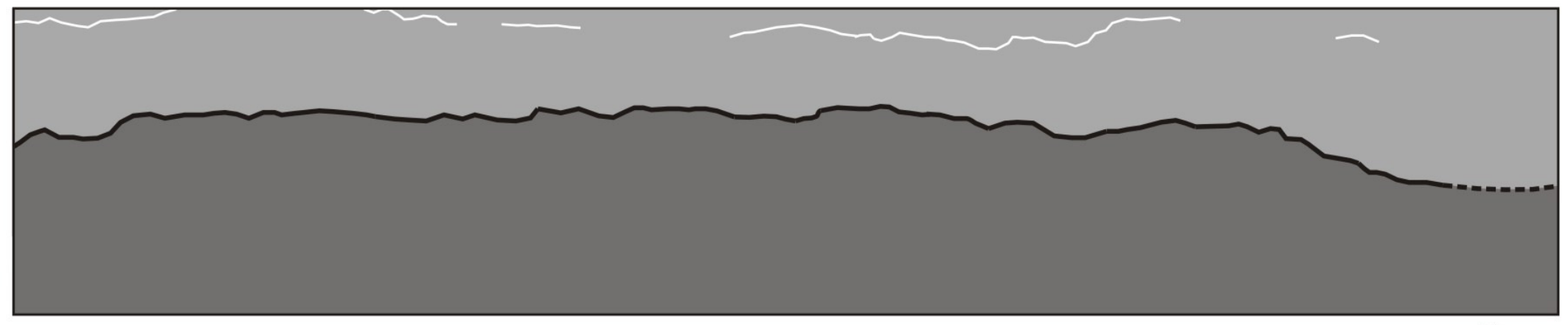

$\mathrm{EV}: 2 \mathrm{X} \underline{25 \mathrm{~m}}$

Figura 41 - Seção de radar 2 (ver localização na figura 39 e legenda na figura 40). Notar que as letras A, C e E mostram a imagem de radar processada, e as B, D e F indicam a interpretação. 


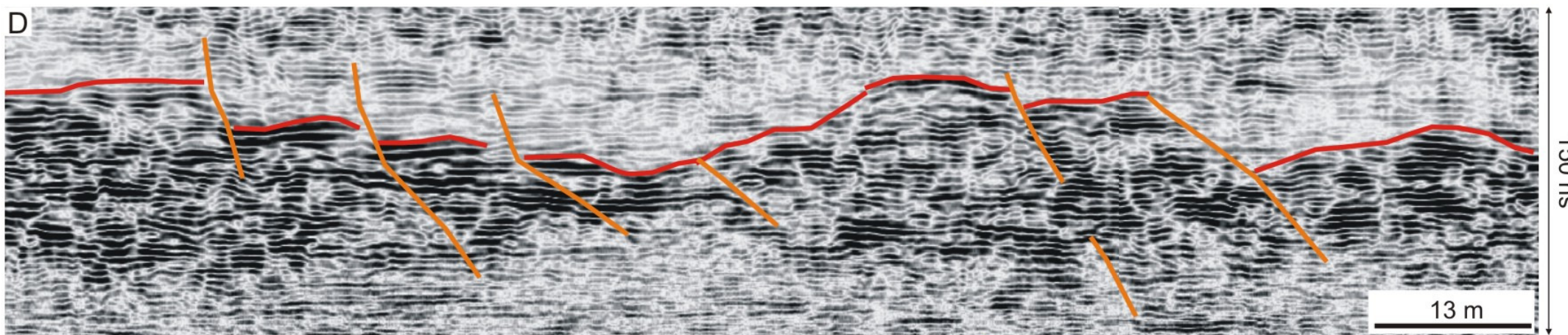

Figura 41 - Continuação. 
통

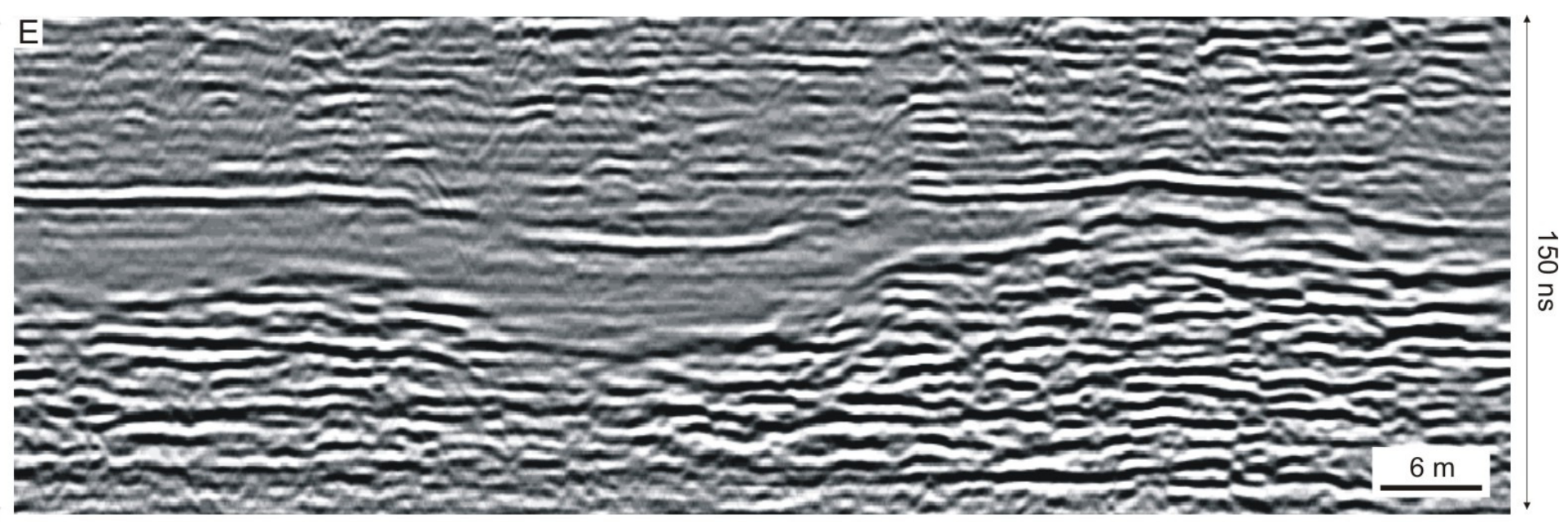

E

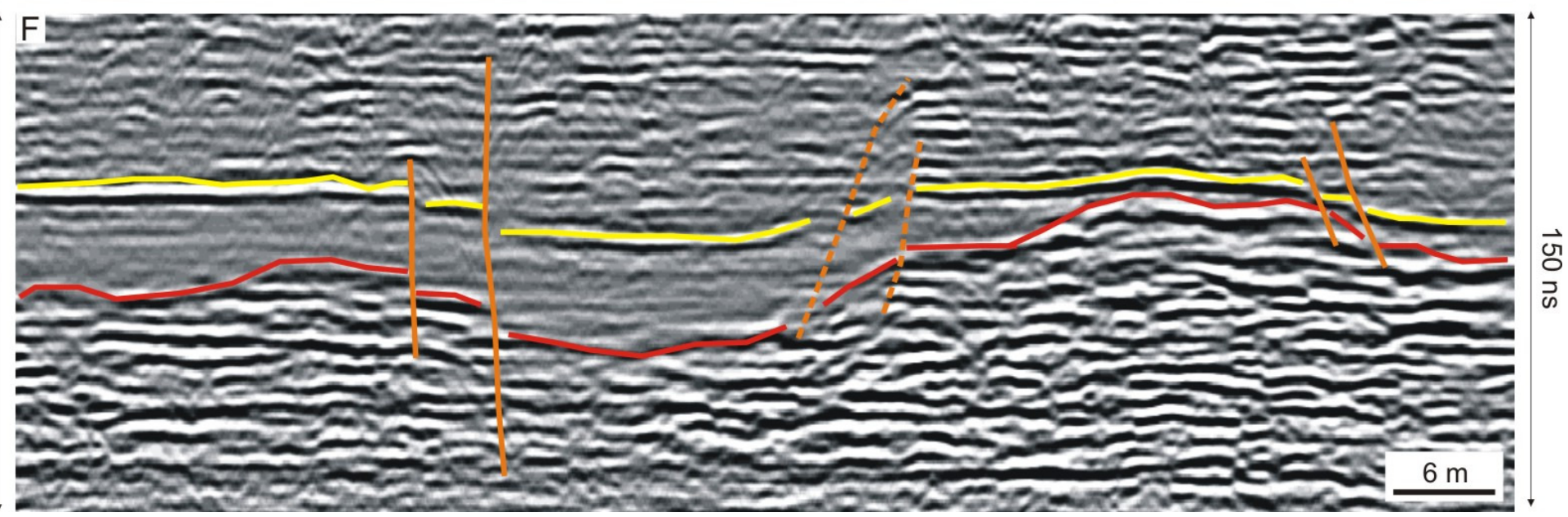

Figura 41 - Continuação. 

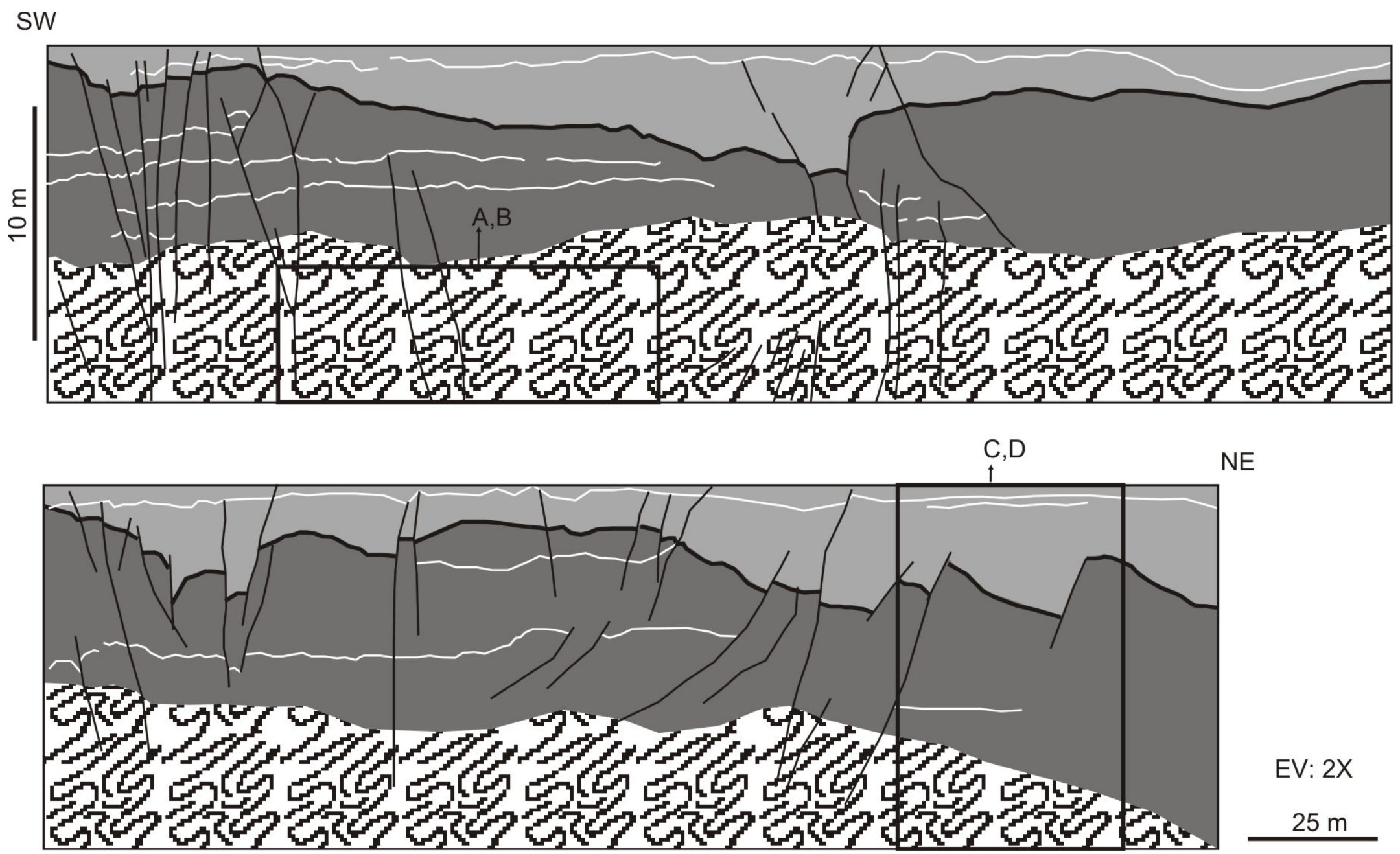

Figura 42 - Seção de radar 3 (ver localização na figura 39 e legenda na figura 40). Notar que as letras A e C mostram a imagem de radar processada, e as B e D indicam a interpretação. 

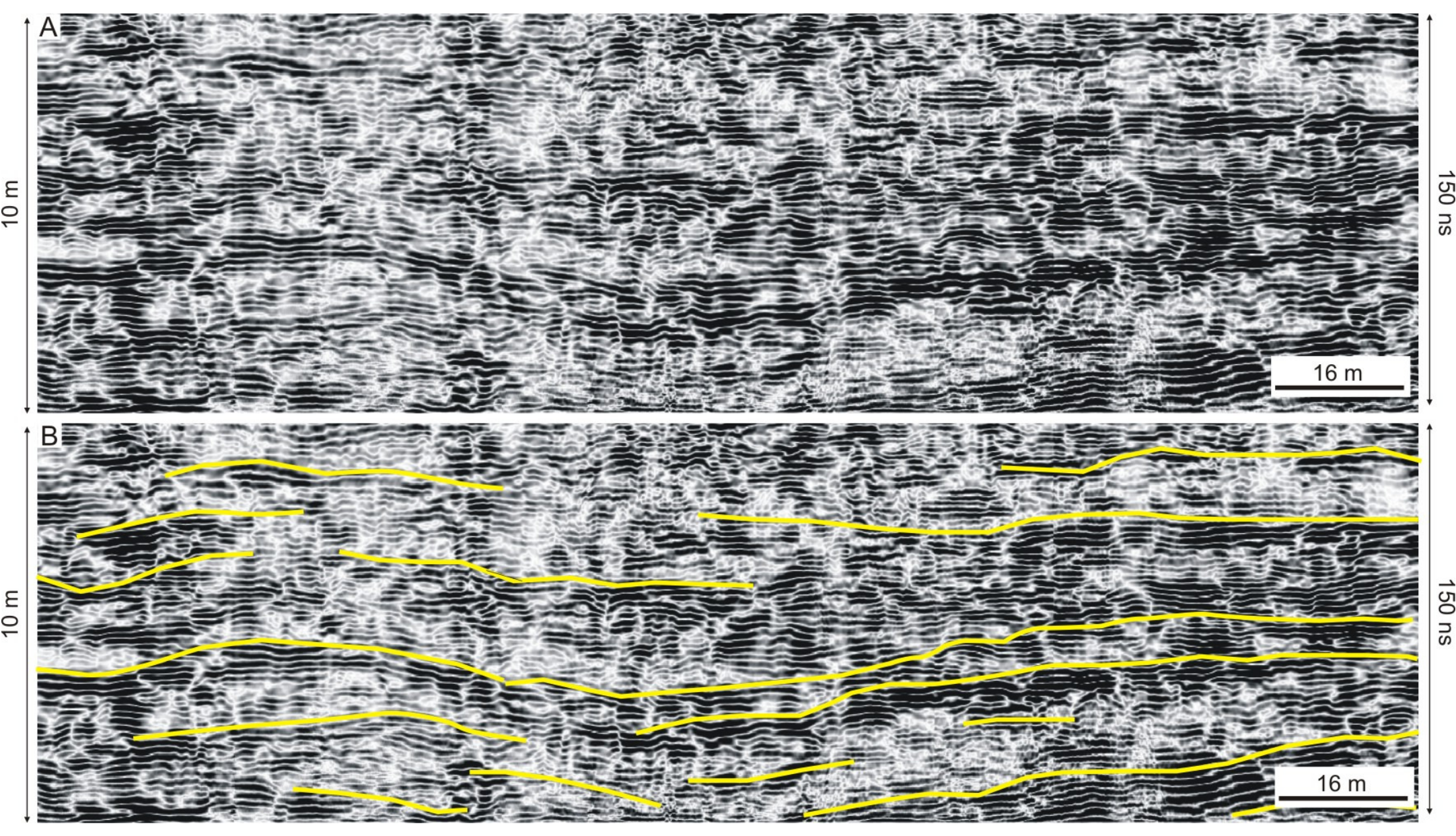

Figura 42 - Continuação. 


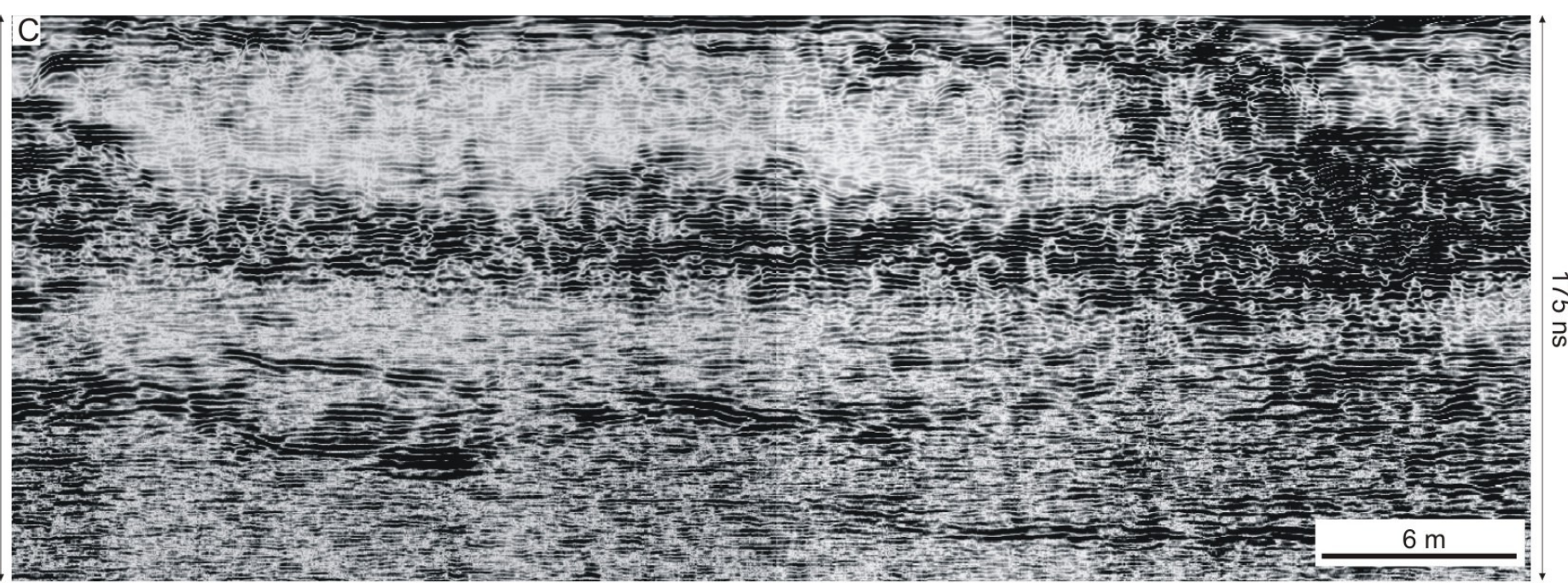

$\stackrel{6}{\circ}$

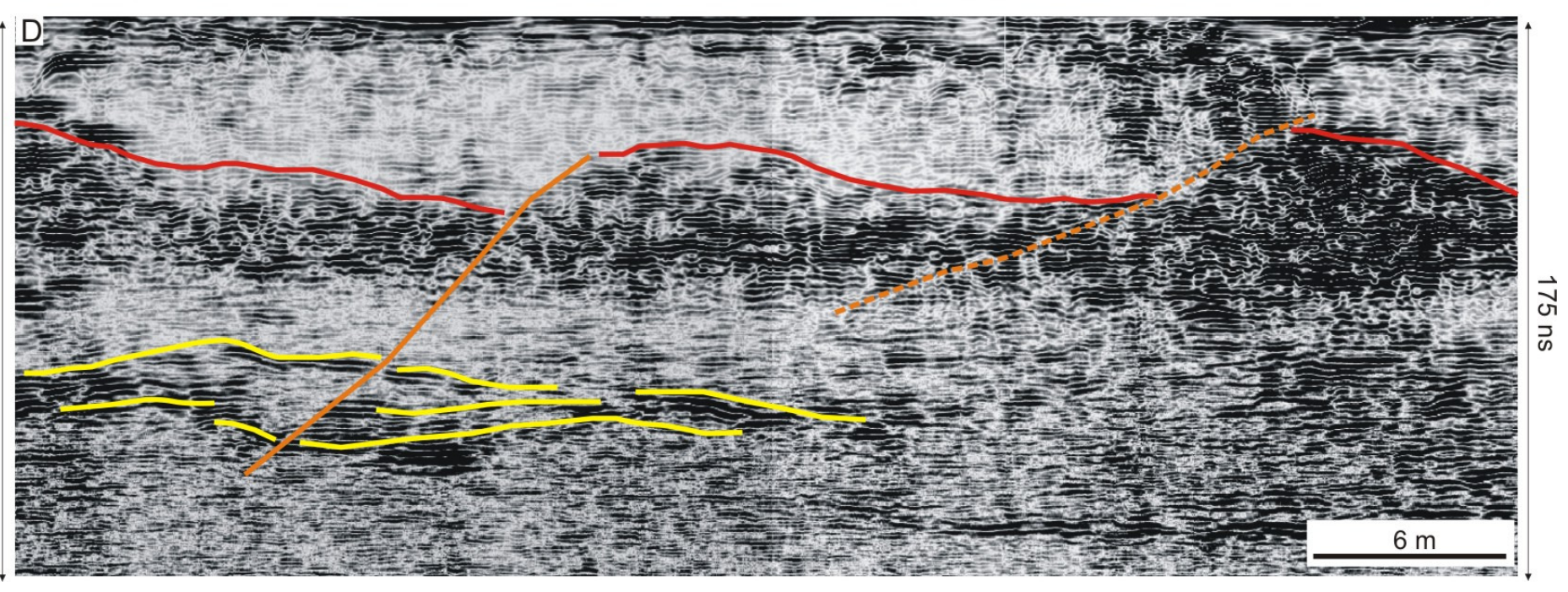

Figura 42 - Continuação. 

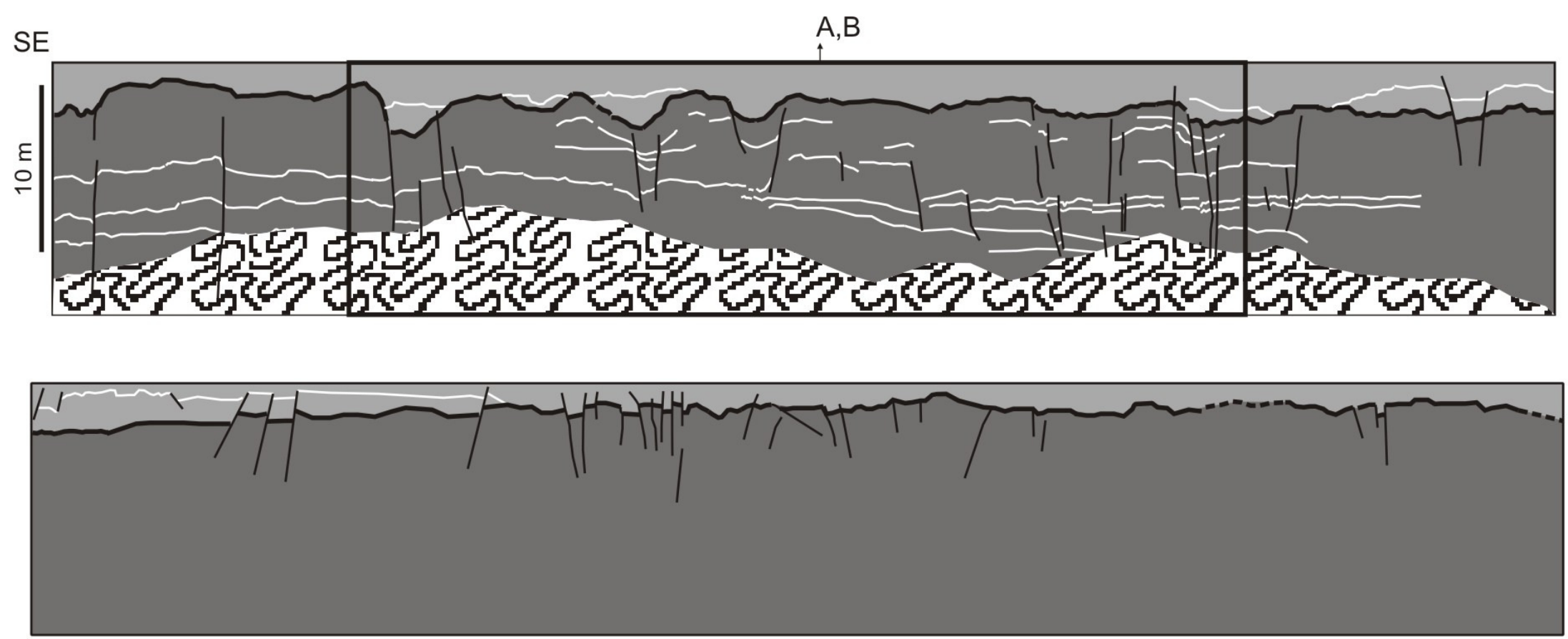

$\mathrm{EV}: 2 \mathrm{2X} \quad 25 \mathrm{~m}$

Figura 43 - Seção de radar 4 (ver localização na figura 39 e legenda na figura 40). Notar que as letras A e C mostram a imagem de radar processada, e as B e D indicam a interpretação. 


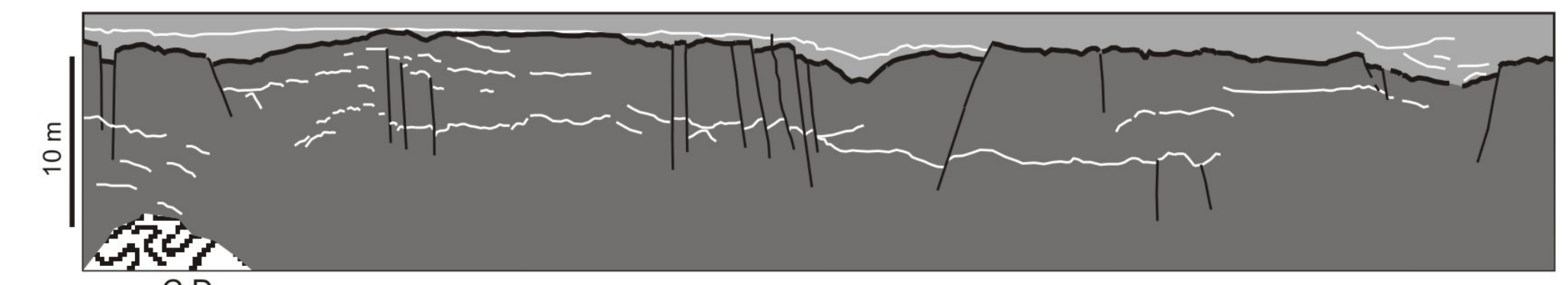
C, D

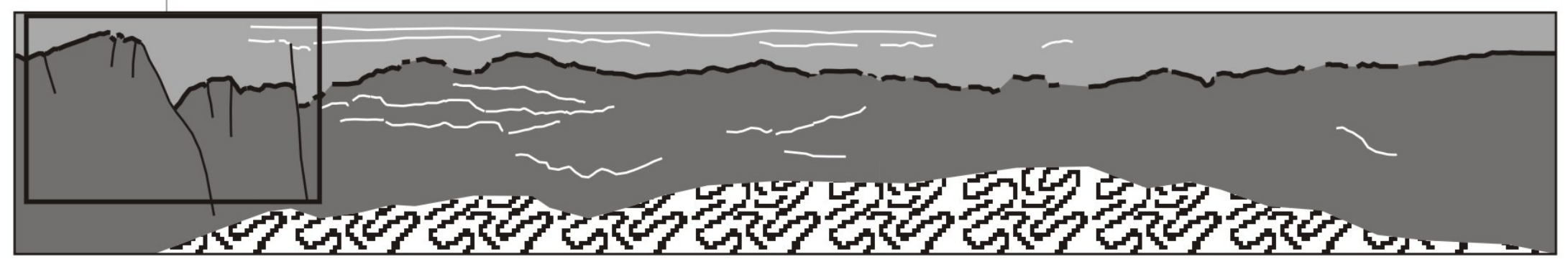

NW

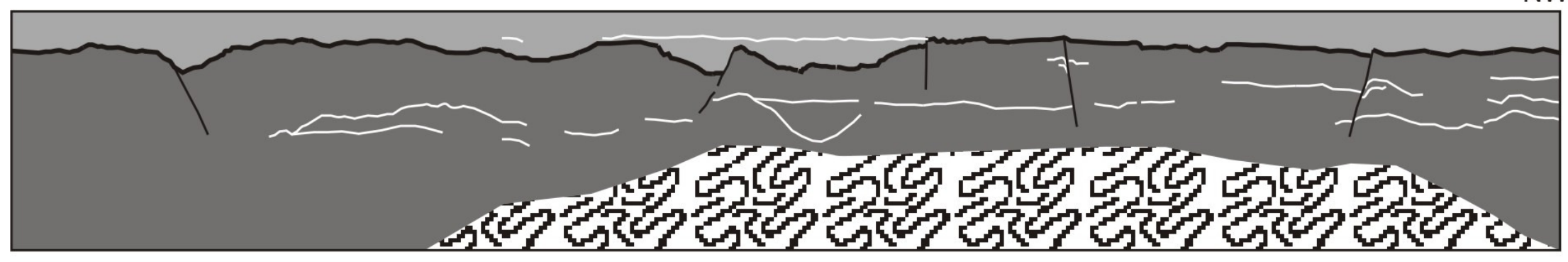

EV: $3 X$

Figura 43 - Continuação. 

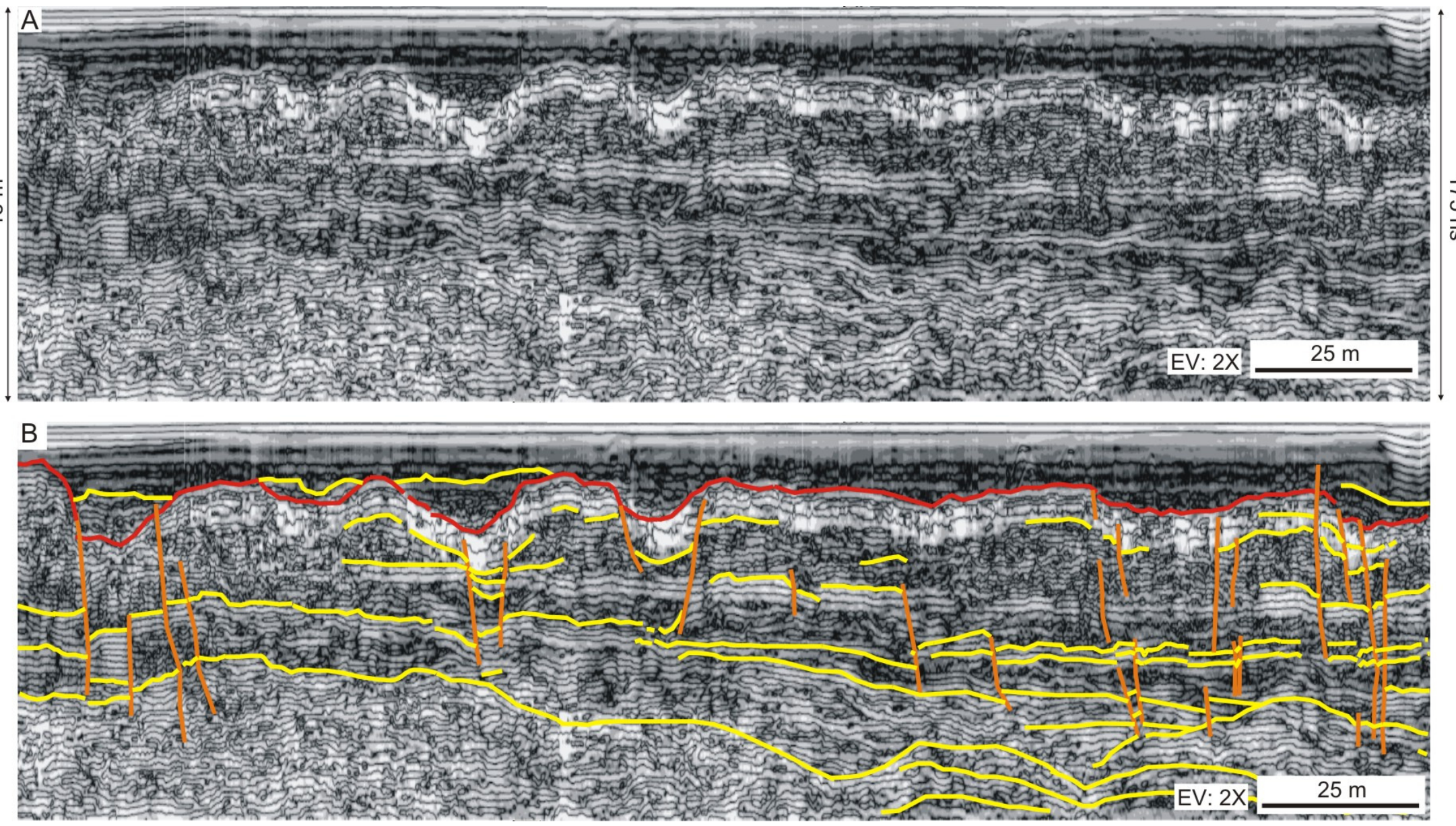

Figura 43 - Continuação. 

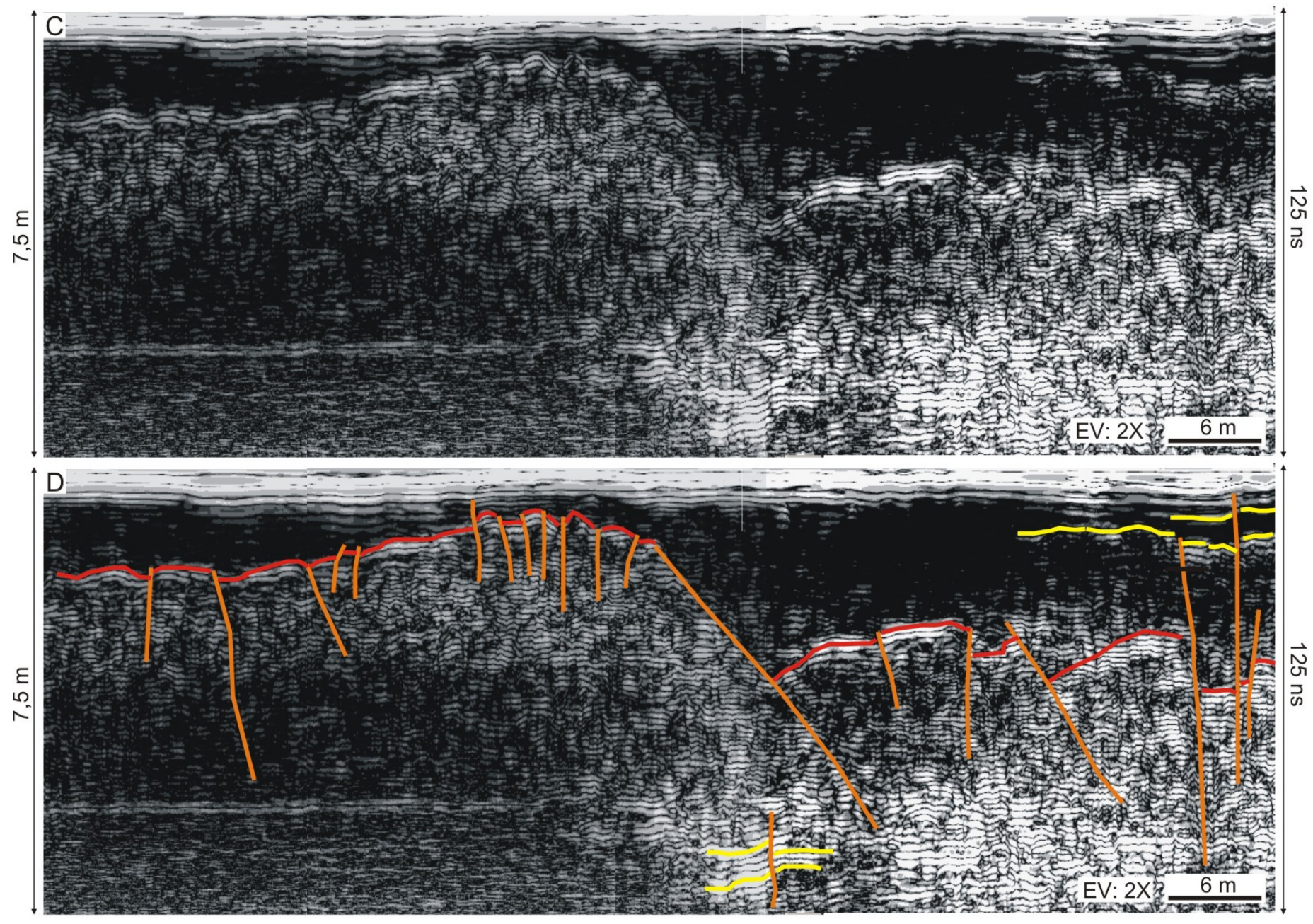

Figura 43 - Continuação. 


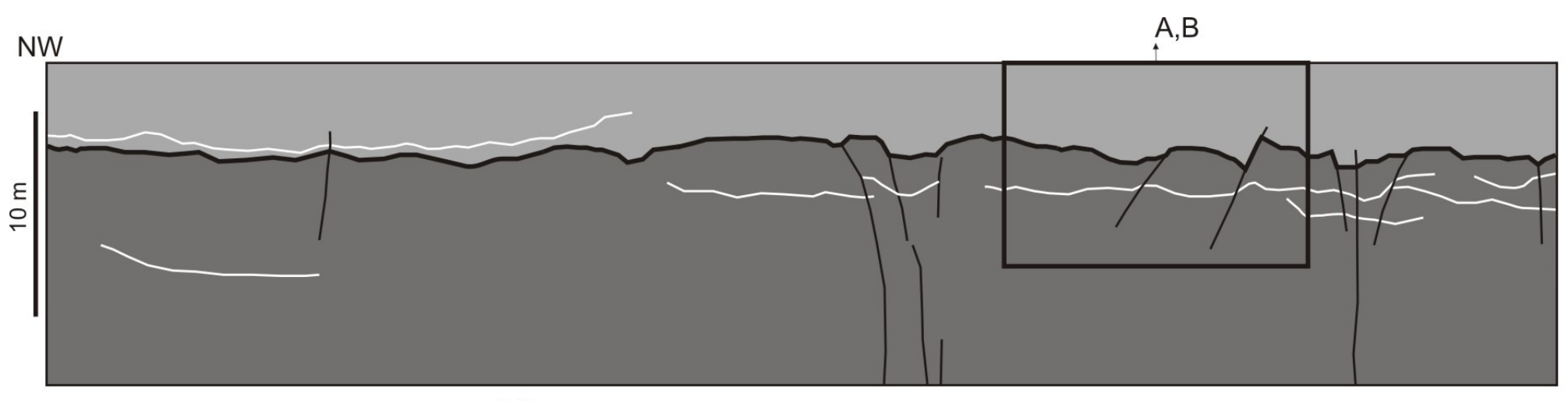

C,D

SE

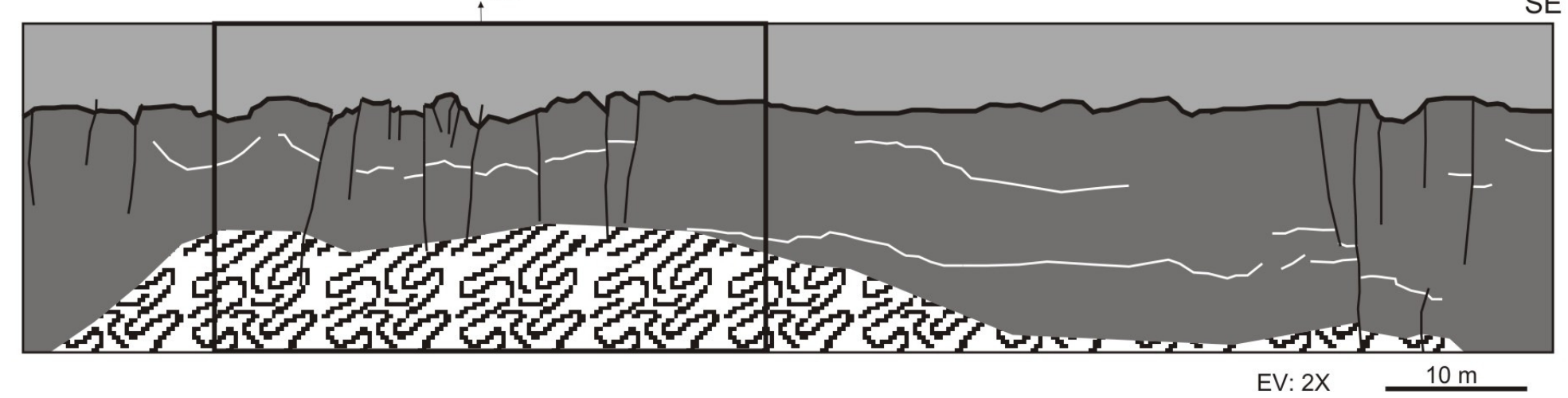

Figura 44 - Seção de radar 5 (ver localização na figura 39 e legenda na figura 40). Notar que as letras A e C mostram a imagem de radar processada, e as B e D indicam a interpretação. 

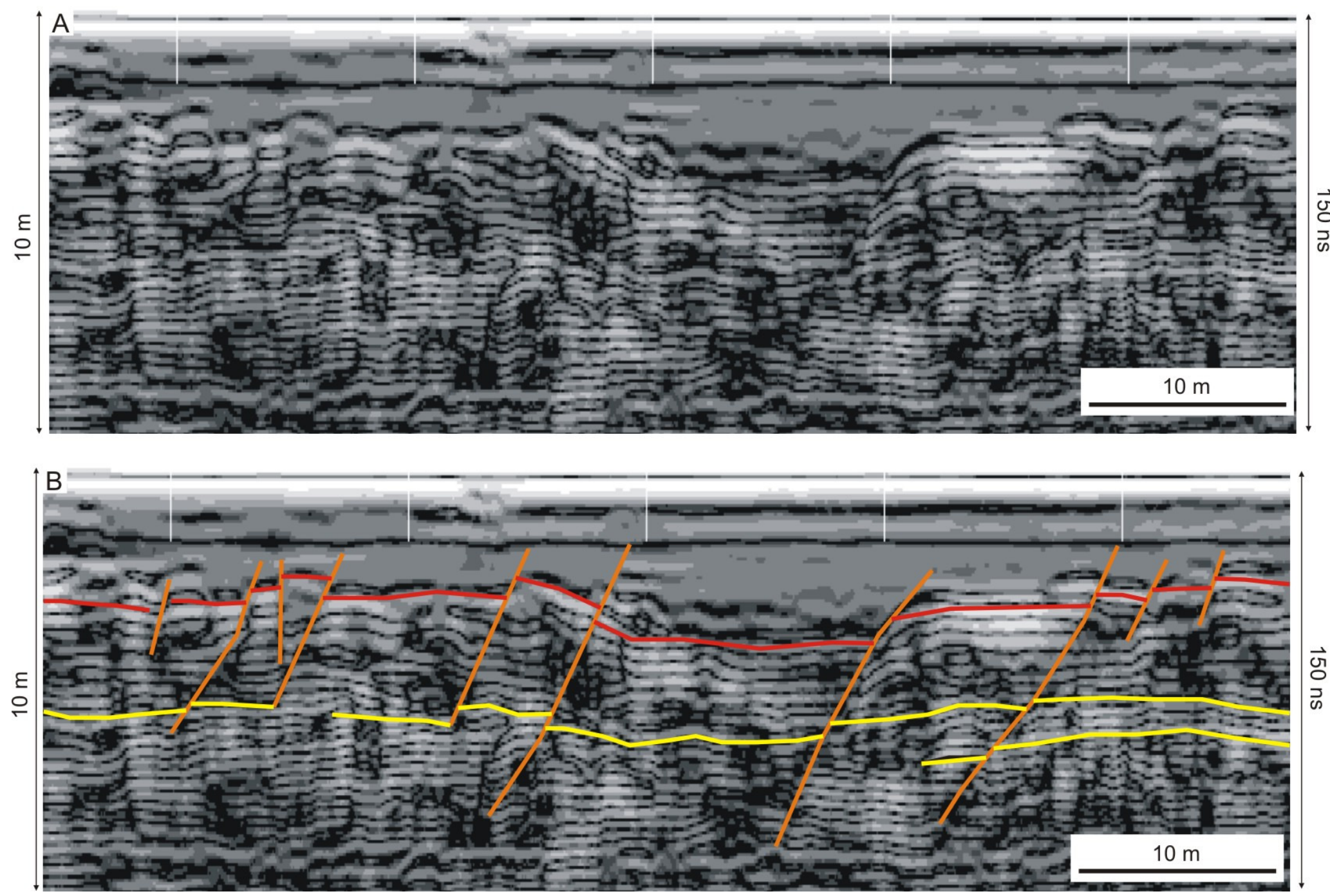

Figura 44 - Continuação. 

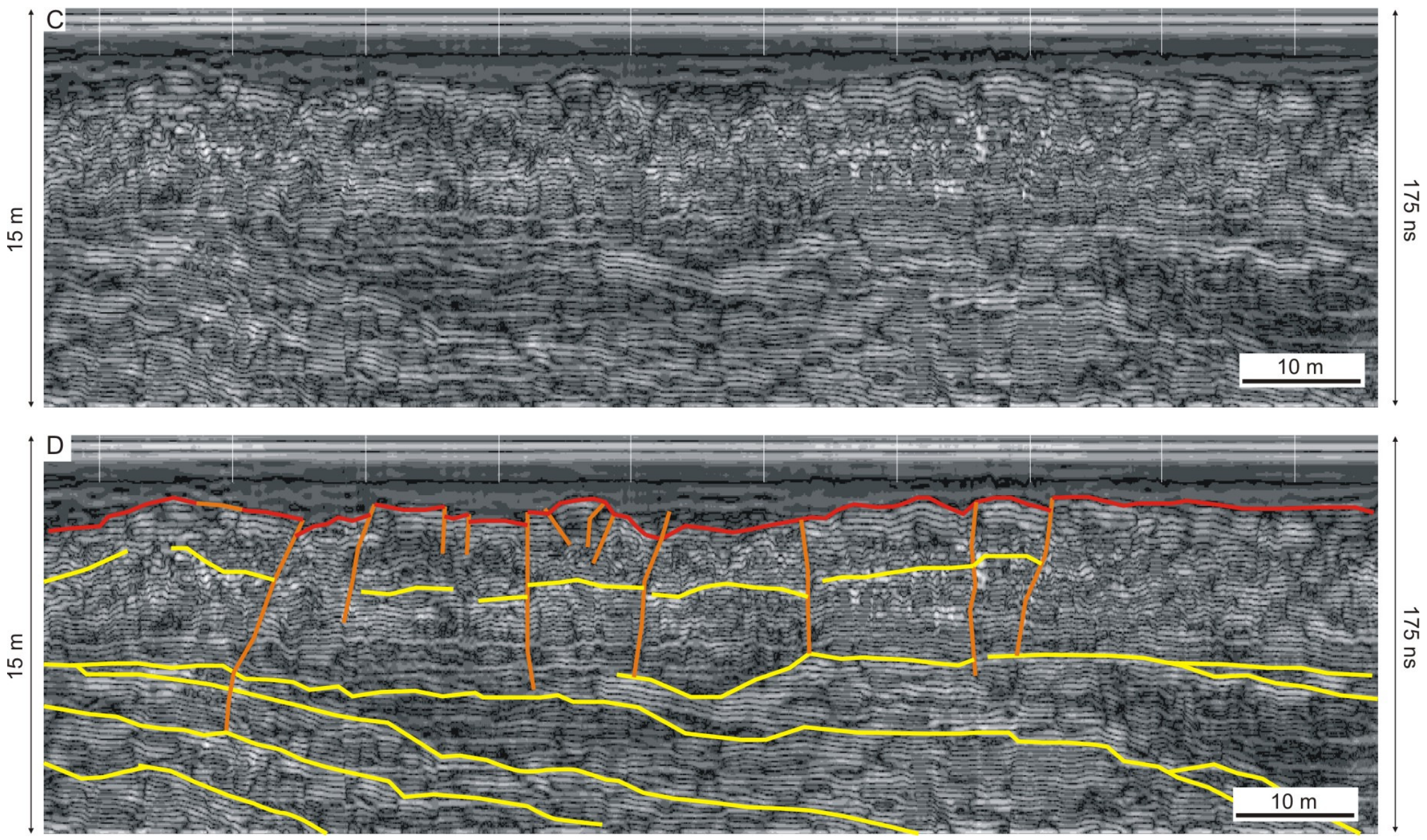

Figura 44 - Continuação. 

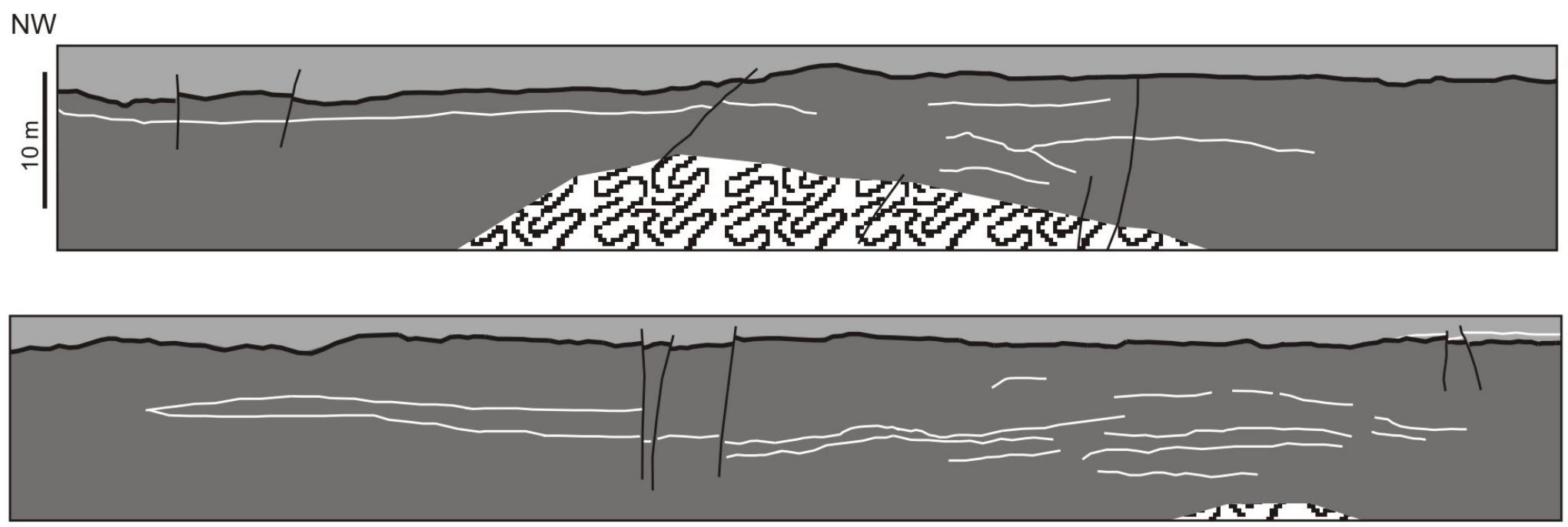

SE

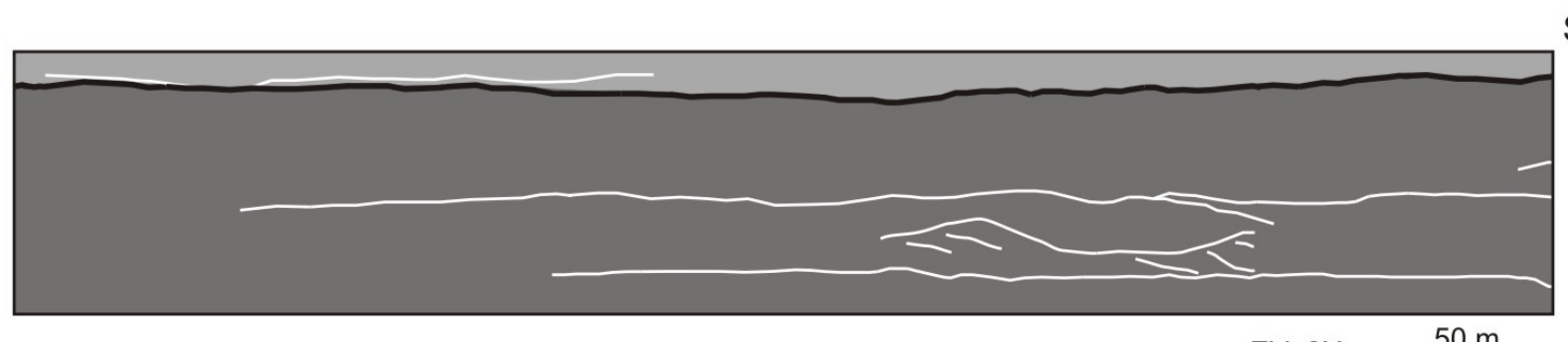

$\mathrm{EV}: 2 \mathrm{X} \longrightarrow \mathrm{m} \mathrm{m}$

Figura 45 - Seção de radar 6 (ver localização na figura 39 e legenda na figura 40). 


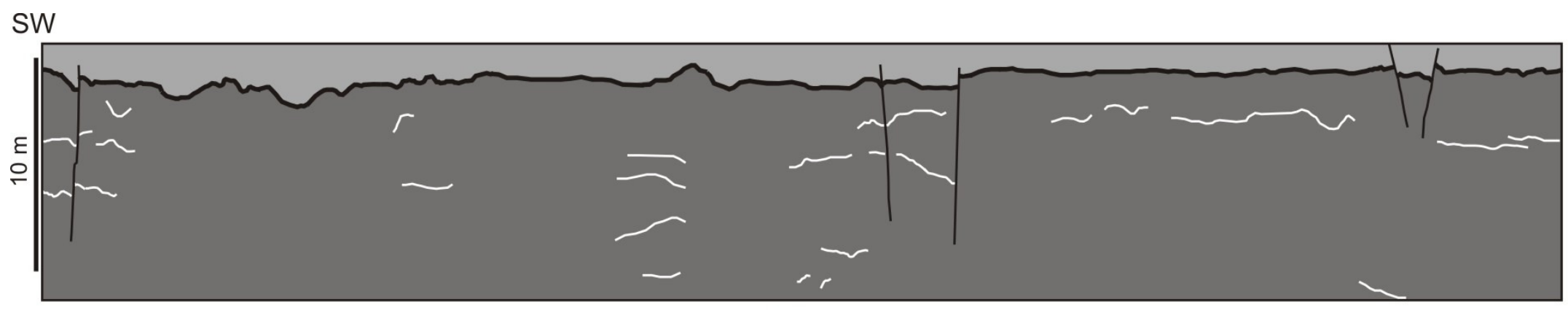

$A, B$.
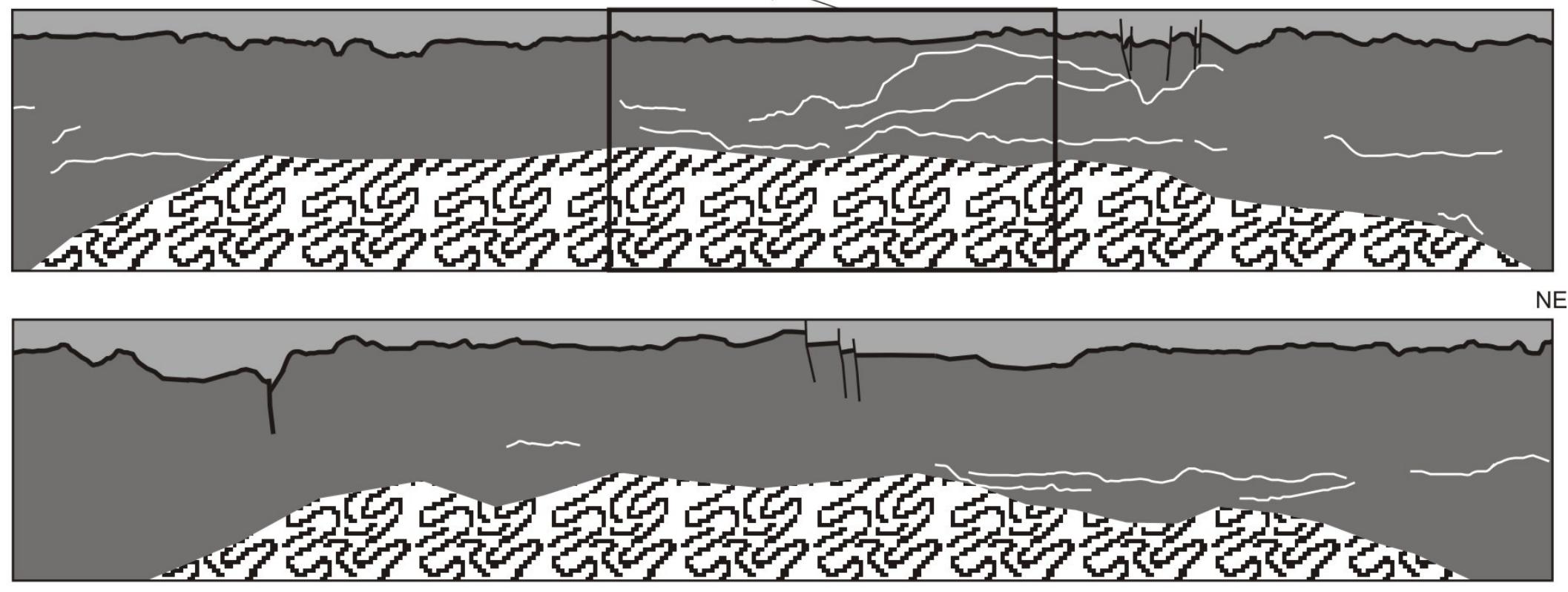

EV: $4 \mathrm{X}$

Figura 46 - Seção de radar 7 (ver localização na figura 39 e legenda na figura 40). Notar que a letras A mostra a imagem de radar processada, e a B indica a interpretação. 

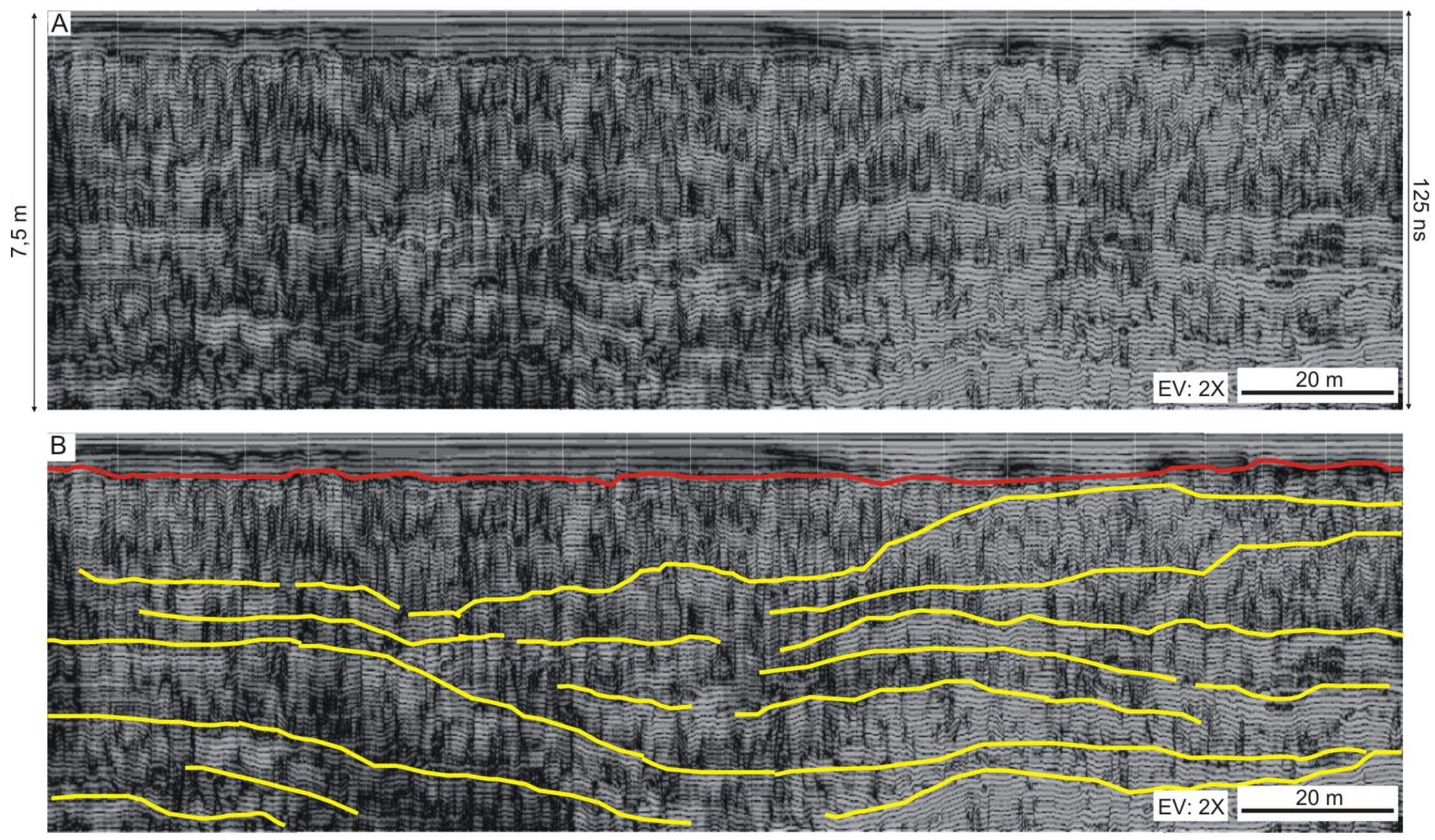

Figura 46 - Continuação. 

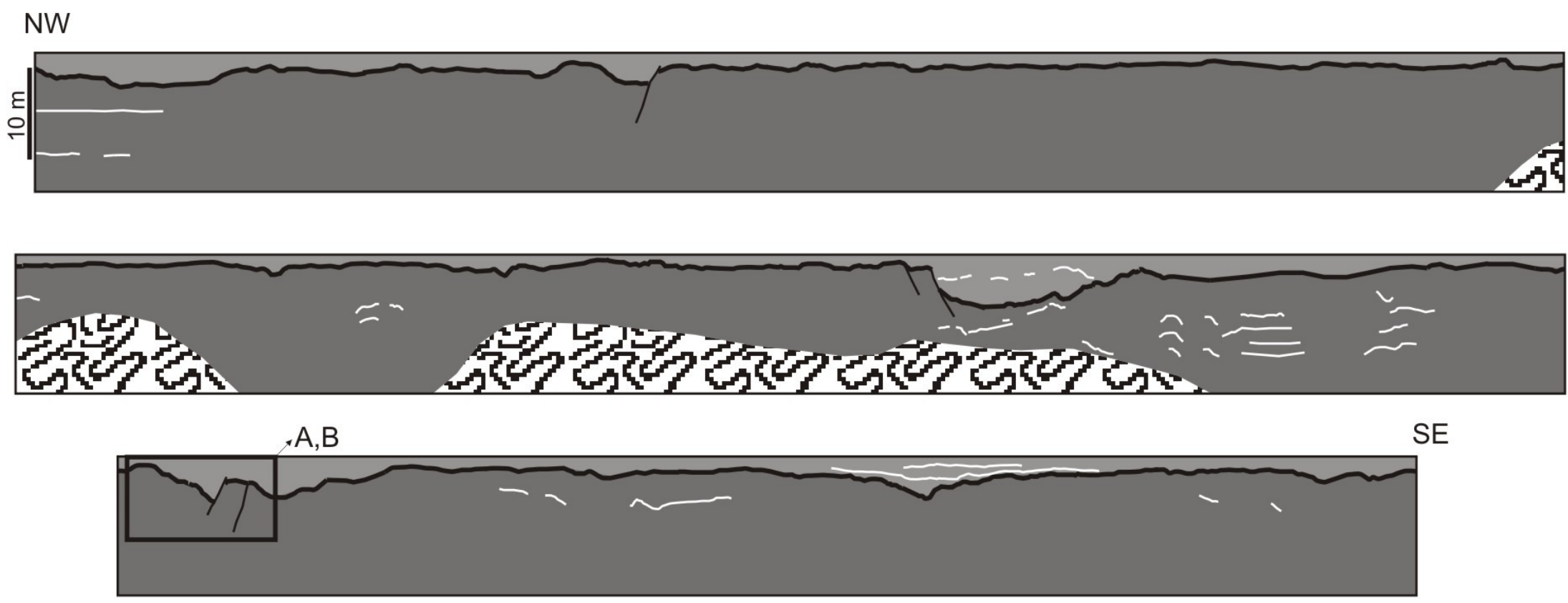

EV: $2 X$

Figura 47 - Seção de radar 8 (ver localização na figura 39 e legenda na figura 40). Notar que a letras A mostra a imagem de radar processada, e a B indica a interpretação. 

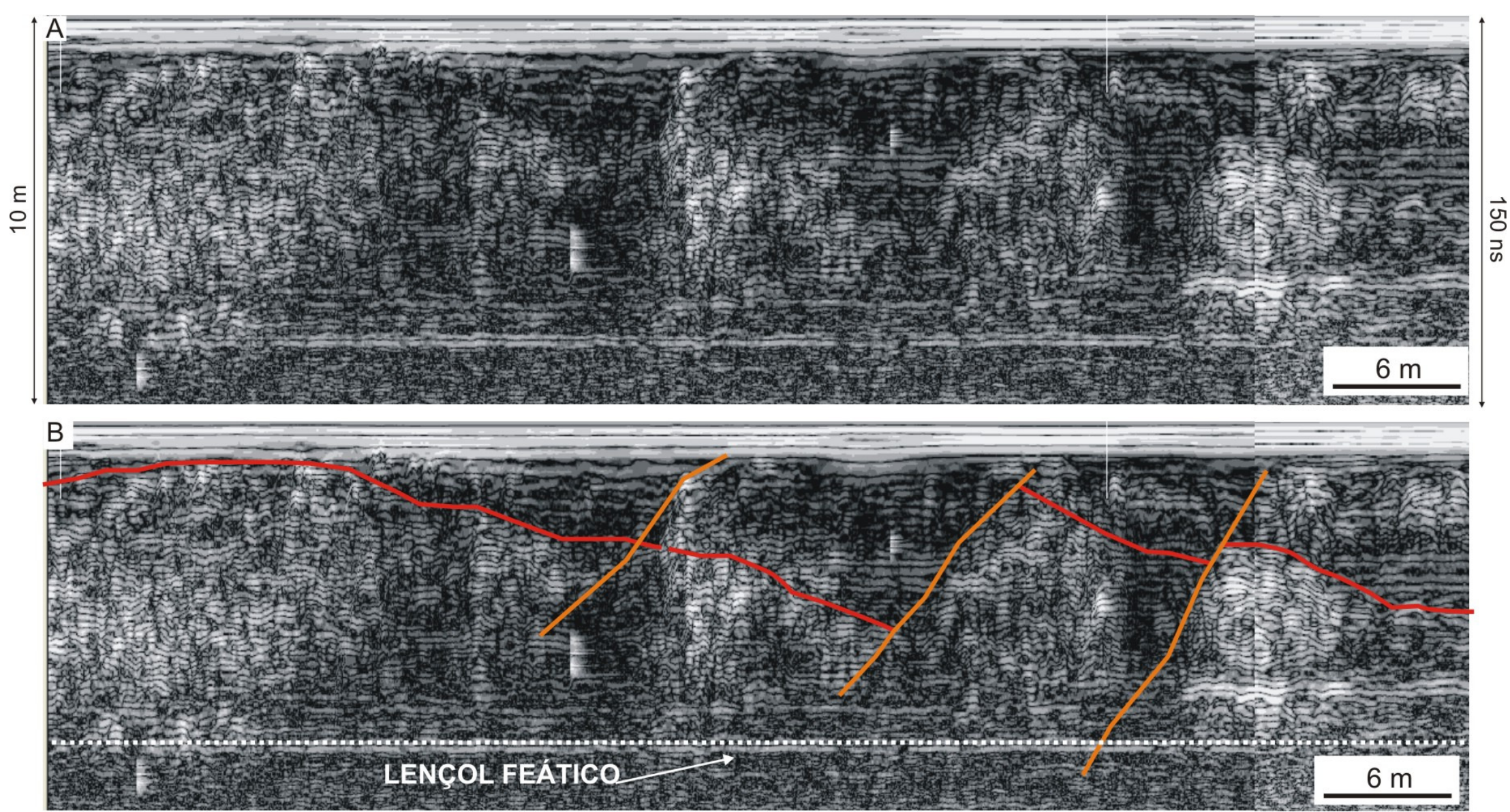

Figura 47 - Continuação. 

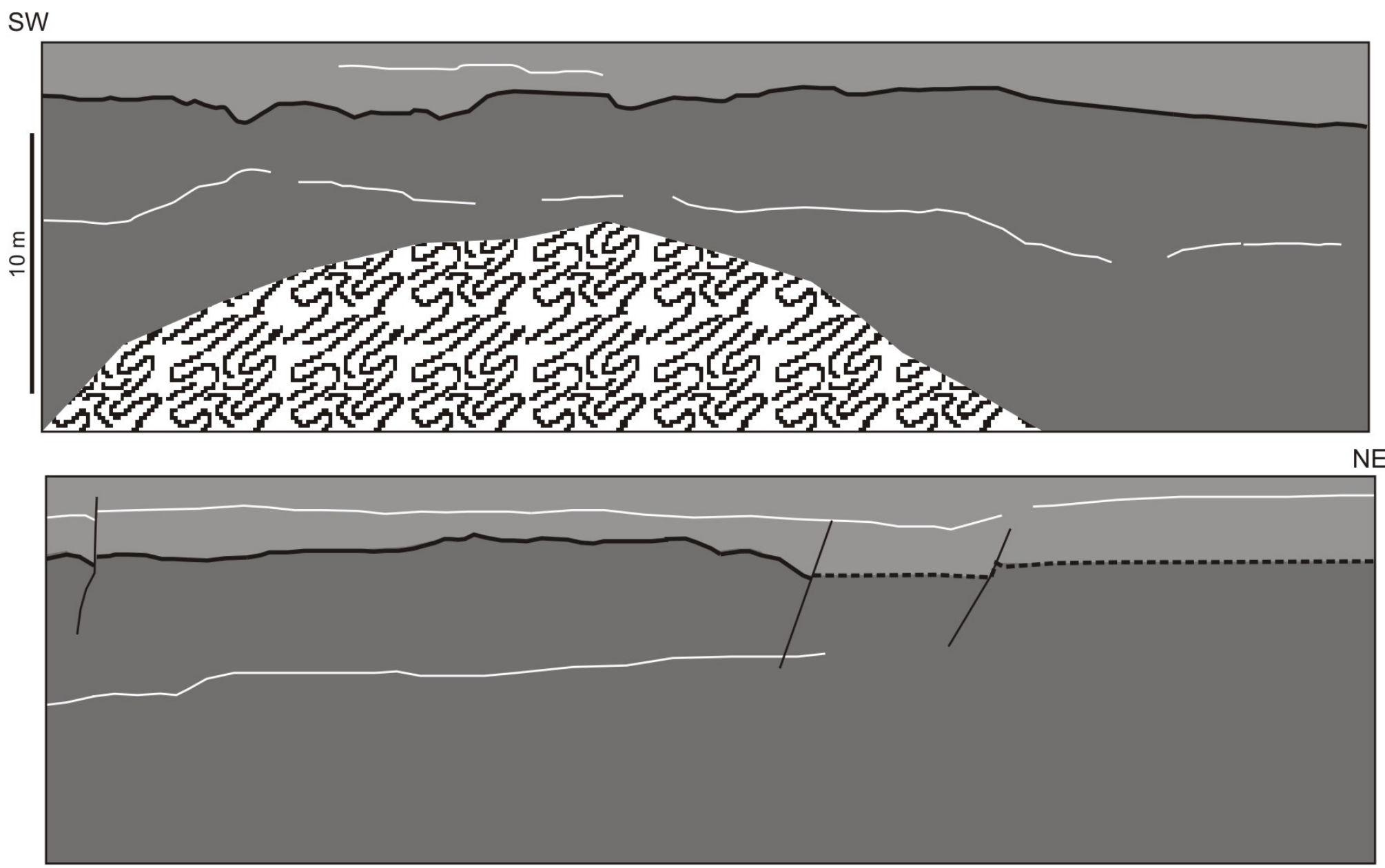

EV: $2 X$

$25 \mathrm{~m}$

Figura 48 - Seção de radar 8 (ver localização na figura 39 e legenda na figura 40). 


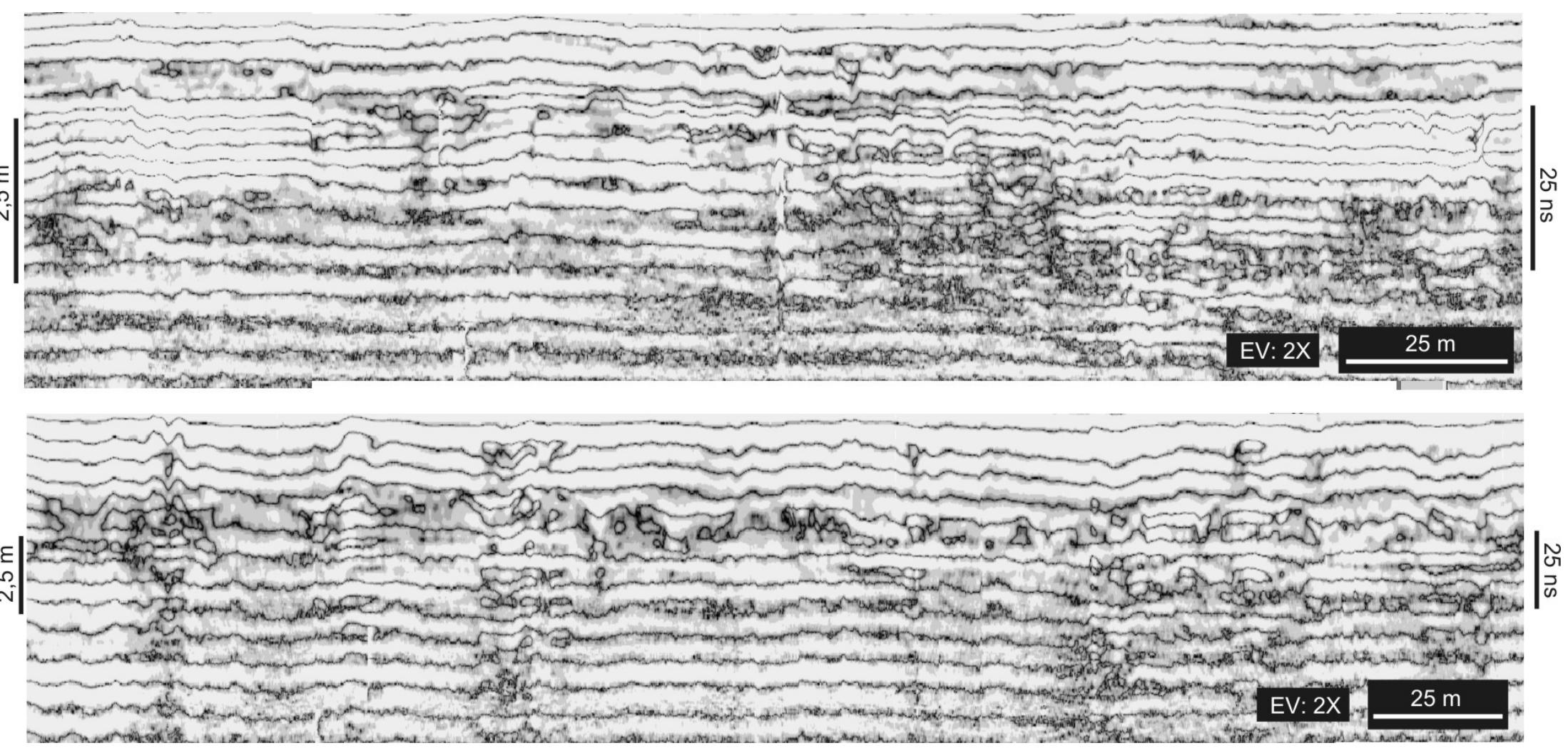

Figura 49 - Exemplos de seções de radar representativas da sedimentação quaternária (ver localização na figura 39 exemplificada pelos lozangos pretos). 

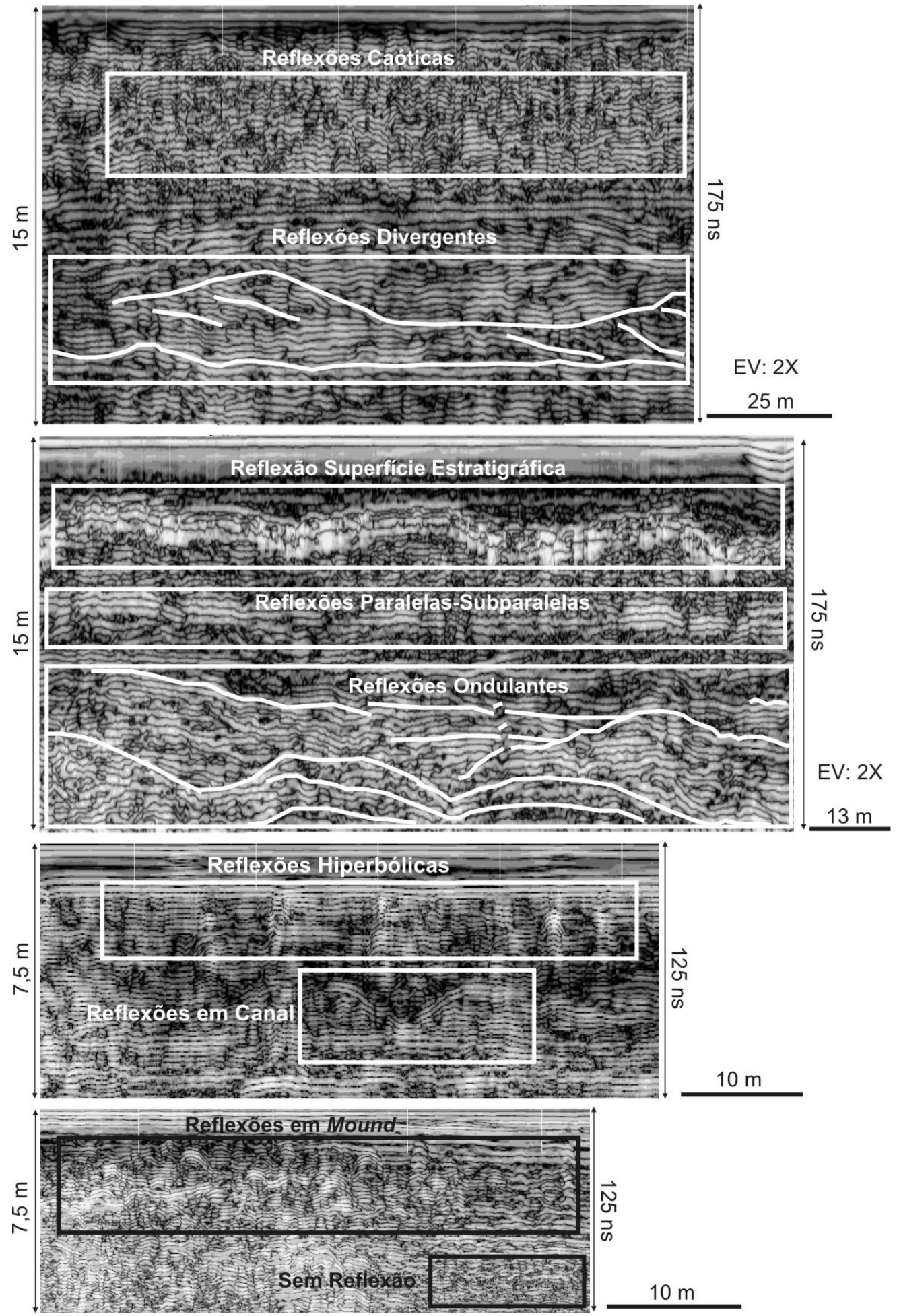

Figura 50 - Tipos de padrão de reflexão identificados na ilha do Marajó. 


\section{DISCUSSÃO}

Os resultados apresentados neste trabalho para a porção leste da ilha do Marajó constituem, em seu conjunto, em elementos sugestivos de evolução sedimentar neógena e quaternária sob influência tectônica. Evidências em suporte a esta proposição derivam de informações de superfície resultante da análise de anomalias de drenagem, lineamentos morfoestruturais e paleodrenagem, combinadas com dados de subsuperfície baseados em sondagem elétrica vertical e radar de penetração no solo. De modo geral, as evidências de superfície, baseadas principalmente na análise de dados orbitais, complementam trabalhos anteriores (Rossetti et al. 2007; Mantelli, 2008; Rossetti, 2008a; Mantelli \& Rossetti, 2009), auxiliando a reforçar inferências tectônicas prévias na região. A integração destes dados com informações de subsuperfície foi crucial na confirmação do efeito de estruturas tectônicas em estratos miocenos e pós-miocenos do leste da ilha do Marajó, além de ter servido, por vezes, para comprovar a ligação entre estruturas mapeadas em superfície e aquelas detectadas em subsuperfície. Com base na demonstração da expressão física de estruturas tectônicas em subsuperfície, pode-se abrir uma discussão sobre possíveis modelos geotectônicos envolvidos na geração de esforços compressivos e distensivos que podem ter atuado nesta parte da margem equatorial brasileira.

\subsection{Evidências tectônicas derivadas da análise de drenagem e da paleodrenagem}

O desenvolvimento de bacias de drenagem mostra, em geral, influências locais e regionais impostas por vários fatores, principalmente litológicos, topográficos, tectônicos e climáticos. Dentre estes, o fator tectônico apresenta-se como o mais provável no controle 
dos sistemas de drenagem da área de estudo. Esta interpretação é sugerida por uma série de características relacionadas com as propriedades de drenagem (atual e pretérita) e com os lineamentos morfoestruturais, como será discutido abaixo. É importante mencionar que as variações mencionadas abaixo não são controladas por mudanças litológicas ou estratigráficas, ou mesmo pelo relevo promovido por estas variações, já que os tipos litológicos expostos na ilha são bastante monótonos, consistindo basicamente em argilitos e arenitos, e a topografia do terreno é tipicamente uniforme e pouco expressiva.

O padrão de drenagem em treliça, dominante na área de estudo, é verificado comumente em associação a terrenos afetados por falhas e fraturas tectônicas (p.e., Holmes, 1965; Howard, 1967; Cristofoletti, 1981; Hare \& Gardner, 1985; Summerfield, 1991). Variações rápidas de padrão dentro de uma mesma bacia, como frequentemente verificado na área de estudo, reforça esta interpretação. Mudanças abruptas na orientação dos cursos d'água, freqüentemente formando ângulos de $90^{\circ}$ e configurando padrões retangulares, como verificado, por exemplo, nos rios Arari e Camará, são comumente relacionados a efeito tectônico. Adicionalmente, as inúmeras anomalias de drenagem, incluindo meandros localizados e comprimidos, canais meandrantes que se tornam bruscamente retilíneos, áreas com alto volume de lagos que configuram drenagem do tipo multibacinal, além da presença de drenagem subparalela, reforçam esta hipótese.

O controle tectônico no leste da ilha do Marajó é, ainda, sugerido pelo FA das bacias de drenagem. Este fator pode revelar terrenos basculados. Valores muito superiores ou muito inferiores a 50 sugerem basculamentos na margem direita e esquerda do rio principal, respectivamente, enquanto que valores próximos a 50 correspondem a áreas com estabilidade tectônica (Keller \& Pinter, 1996; Marques Neto \& Viadana, 2006). Portanto, os valores de $\mathrm{FA}=62$ e $\mathrm{FA}=71$ para as $\mathrm{BDRC}$ e BDRP, respectivamente, são compatíveis 
com basculamentos da margem direita do rio. $\mathrm{O}$ valor de $\mathrm{FA}=42$ para a BDRA mostra que esta área esteve relativamente mais estável. Entretanto, se considerado apenas as margens do alto curso do rio Arari, onde o $\mathrm{FA}=84$, pode-se concluir que este setor da bacia esteve, também, sob influência tectônica, sugerindo basculamento para a direita. A variação de valores de FA ao longo desta bacia pode registrar heterogeneidades na distribuição de esforços tectônicos (Holmes, 1965; Howard, 1967; Cristofoletti, 1981). Portanto, conclui-se que, quando combinados às anomalias de drenagem descritas neste trabalho, os valores de FA das três bacias estudadas podem ser utilizados para ajudar a reforçar a hipótese de efeito tectônico na área de estudo.

O fato dos lineamentos morfoestruturais não apresentarem distribuição aleatória, mas seguirem padrão com modas principais para NW-SE e NE-SW e subordinadas para E-W e NNE-SSW/NNW-SSE, é um elemento a mais para se sugerir controle tectônico no desenvolvimento da drenagem atual do leste da ilha do Marajó. O fato destes direcionamentos coincidirem com a orientação de falhas tectônicas reconhecidas em várias bacias sedimentares da região amazônica, como será discutido no item 9.4., é consistente com esta proposição.

Considerando-se proposta de controle tectônico na área de estudo, interpretação reforçada pelos dados de SEV e GPR abaixo apresentados, a maior densidade de lineamentos orientados para NW-SE e NE-SW no compartimento morfoestrutural I pode ser explicado seja pela maior deformação tectônica, seja pela presença de terrenos geologicamente mais antigos próximos à superfície neste setor. A segunda interpretação é preferida aqui, uma vez que, enquanto o compartimento II apresenta somente depósitos quaternários expostos à superfície, o compartimento I contém ampla distribuição de depósitos miocenos (Rossetti, 2010). Uma possibilidade de interpretação é que, por conter 
depósitos mais antigos próximo à superfície, o compartimento I registre diferentes eventos tectônicos, enquanto que os lineamentos do compartimento II registrariam apenas estruturas formadas mais recentemente. Esta interpretação é condizente com o fato de haver maior concentração de lineamentos morfoestruturais NW-SE e NE-SW no compartimento I, enquanto o compartimento II apresenta predomínio de lineamentos NE-SW. Este padrão pode ser explicado pelo fato de falhas tectônicas de direção NW-SE predatar falhas orientadas para NE-SW no leste da ilha do Marajó (Rossetti et al. 2007). Portanto, o compartimento I, mais antigo, tem maior potencial de registrar estes eventos tectônicos, enquanto o compartimento II, mais jovem, registraria somente o último evento de reativação de direção preferencial NE-SW. Não se pode descartar totalmente a possibilidade de que os eventos tectônicos teriam ocorrido de forma diferencial, tendo afetado mais fortemente, o compartimento I.

Com relação aos paleocanais, várias hipóteses podem ser levantadas para explicar seu abandono no leste da ilha do Marajó: (a) diminuição no nível do lençol freático devido à maior aridez durante a partir do final do Pleistoceno; (b) oscilação do lençol freático devido à queda eustática; e (c) ação tectônica. A primeira hipótese não parece contundente com reconstituições paleoclimáticas na Amazônia, onde se registra aumento progressivo de umidade no Holoceno (Baker et al. 2001; Sifeddine et al. 2001), quando os canais do leste da ilha do Marajó parecem ter sido preferencialmente abandonados (Rossetti et al. 2008a). A segunda hipótese também parece não ser confirmada, já que o nível eustático teve comportamento dominante de elevação durante o Holoceno (Behling \& Costa, 2000; Behling, 2001; Souza Filho \& Paradella, 2003; Cohen et al. 2004 e 2005a, b; Vedel et al. 2006). Portanto, ação tectônica parece ser a mais provável, principalmente quando se leva em consideração o contexto estrutural proposto para a ilha do Marajó (Rossetti \& 
Valeriano, 2007; Rossetti et al. 2008a). De acordo com estes autores, o paleoestuário Arari teria sido abandonado no leste da ilha quando esta se destacou do continente, processo este que resultou na abertura da baía de Marajó. O mais provável, então, é que a abertura dessa baía interrompeu o fluxo fluvial derivado de áreas continentais para o interior da ilha, o que teria causado modificação nos sistemas de drenagens, e também o abandono do paleoestuário Arari. À medida que este processo ocorreu, as bacias de drenagem passaram a ser capturadas e desviadas para sudeste, fluindo em direção àquela baía. A presença de anomalias na paleodrenagem, representada por freqüentes desvios de curso em ângulo reto e paleomeandros isolados e comprimidos, é consiste com a hipótese de que a drenagem pretérita neste setor da ilha também esteve sob controle tectônico.

\subsection{Evidências tectônicas derivadas da integração de dados geoelétricos, geológicos e morfoestruturais}

Interpretações litológicas baseadas somente em sondagem elétrica vertical podem ser problemáticas. Isto porque valores de resistividade aparente refletem a média entre valores representativos de várias litologias dentro de um pacote heterogêneo, sendo dependente da resistividade dos materiais, de suas frações em volume, e de sua distribuição geométrica em subsuperfície. Estas características influenciam as medidas elétricas para uma determinada abertura e arranjo de eletrodos. Se uma porção do terreno tem resistividade elevada, devese considerar que o pacote referido pode possuir, por exemplo, não somente camadas de areia grossa, mas também volumes subordinados de argila e/ou pelitos. O contrário também

pode ocorrer, ou seja, um pacote argiloso ou de depósitos heterolíticos de resistividade baixa pode incluir camadas delgadas de areia e/ou seixo, de maior resistividade. Além 
disto, litologias similares pertencentes a unidades geológicas distintas podem apresentar valores de resistividade comparáveis.

$\mathrm{Na}$ área de estudo, algumas dificuldades puderam ser constatadas quanto à interpretação dos dados geoelétricos. Assim, estratos quaternários mostraram condutividade, em geral, alta, o que sugere domínio de litologias lamosas, o que é também indicado pela prevalência de curvas resistivas dos tipos 3 e 4 (ver figura 34C, D). Porém, a análise de dados derivados de testemunhos de sondagem (Figura 31) revelou que estes depósitos não são totalmente constituídos de argilas, mas contém, muitas vezes, intercalações de camadas arenosas de granulometria fina. Além disto, camadas com litologias similares pertencentes a sucessões sedimentares temporalmente diferentes apresentaram valores de resistividade que não permitiram sua distinção.

Apesar das limitações naturais quanto à interpretação litológica feita com base em dados de SEV, a integração deste tipo de informação com dados geológicos e de superfície permitiram conclusões importantes sobre a área de estudo. Em particular, o conhecimento prévio da existência marcante de horizonte de paleossolo laterítico no topo da Formação Barreiras, bem como de estratos fortemente cimentados por ferro logo abaixo desta superfície, foi fundamental para o controle estratigráfico e visualização da distribuição espacial das unidades sedimentares. Como registrado em várias publicações prévias (p.e., Rossetti, 2004, 2006), este paleossolo é bastante expressivo e regionalmente significante, servindo de marco estratigráfico para o limite entre a Formação Barreiras e os depósitos quaternários sobrejacentes, independentemente do arcabouço geológico e/ou bacia sedimentar. De acordo com os autores supracitados, este paleossolo, cujo desenvolvimento iniciou-se por exposição subaérea relacionado com o rebaixamento do nível do mar no Tortoniano/Messiniano, possui horizonte concrecionário ferruginoso que pode atingir 
vários metros de espessura. Concreções ferruginosas se constituem em material de altíssima resistividade. Para o caso da área de estudo, a integração de dados de SEV com dados de afloramentos da porção leste, onde este horizonte laterítico é exposto na superfície ou é subaflorante em profundidades rasas (Figura 30, ver também item 8.3), revelou valores de resistividade entre $500 \Omega \mathrm{m}$ e $13.000 \Omega \mathrm{m}$. Com base nesta correlação de dados, pode-se atribuir os valores mais elevados de resistividade detectados na porção superior das seções estudadas da área de estudo ao nível concrecionário do paleossolo laterítico do topo da Formação Barreiras. Além disto, estes valores elevados podem adicionalmente refletir diferentes graus de cimentação por ferro dos estratos que ocorrem subjacentes a este horizonte. Esta interpretação levou em consideração observações de campo feitas na área de estudo, bem como em várias outras áreas de ocorrência da Formação Barreiras, onde tais depósitos cimentados por ferro têm sido comumente registrados.

Portanto, o mapeamento do intervalo apresentando os valores mais elevados de resistividade próximos à superfície possibilitou delimitar o topo da Formação Barreiras nas seções de SEV. Com isto, pode-se prosseguir com a verificação da relação de contato entre esta unidade e os estratos quaternários sobrejacentes. Estes, por sua vez, foram identificados com base na integração dos dados de SEV com informações faciológicas e cronológicas (i.e., datações radiogênicas ${ }^{14} \mathrm{C}$ ) derivadas dos testemunhos de sondagem interceptados pelas seções geológicas representativas dos transectos geoelétricos aqui apresentados (Figuras 30 e 31).

Considerando-se as premissas acima expostas, então a brusca interrupção nos valores de resistividade elevada pouco a norte da SEV-9 na seção A-A' pode ser interpretada como representativa do desaparecimento súbito da Formação Barreiras nesta localidade. Como a 
norte deste ponto registrou-se somente depósitos quaternários, pode-se inferir que o contato entre estes depósitos cronologicamente distintos ocorre, mais provavelmente, por falha tectônica. A presença, nas adjacências do local sugerido para a falha, de segmentos de lagos retilíneos e ortogonais que estão em continuidade lateral com morfologias de paleocanal e com lineamentos morfoestruturais, estes igualmente retilíneos e ortogonais, são condizentes com esta interpretação. Tais características morfológicas permitem sugerir que os lagos presentes no entorno da SEV 9 constituem o registro de uma drenagem remanescente, que se tornou bloqueada em vários setores devido ao deslocamento de falhas. Estudo anterior (p.e., Rossetti et al. 2008b) já havia sugerido que o abandono desses canais, bem como de muitos outros já mapeados na ilha do Marajó, possa estar associado à reativação de falhas. Neste contexto, o segmento do lago São Luís que sofre inflexão para nordeste e está em continuidade física com lineamento morfoestrutural retilíneo de direção NE-SW pode representar a expressão em superfície da falha interpretada na seção A-A'. Considerando-se modelo tectônico dominado por esforços distensivos, esta falha, detectada em subsuperfície e com expressão em superfície dada pelo lineamento morfoestrutural de direção NE-SW acima comentado, seria do tipo normal, tendo mergulho geral para NW.

Uma possibilidade de interpretação para a falha inferida entre as SEVs 9 e 60 é que os estratos quaternários teriam sido depositados sobre a Formação Barreiras e posteriormente, posicionados lateralmente à esta unidade como resultado de falhamento. Entretanto, o mais plausível é que estes estratos quaternários tenham se formado em área subsidente concomitante à geração de espaço acomodacional derivado pelo deslocamento de falha. A ocorrência de estratos quaternários em contato brusco com a Formação Barreiras nas margens do lago São Luís (i.e., P7 e P8 nas figuras 32 e 35) é relacionada ao preenchimento de um paleocanal desenvolvido sobre a Formação Barreiras durante o Pleistoceno Tardio. 
Similarmente à seção A-A', o desaparecimento rápido da Formação Barreiras entre as SEVs 41 e 38 no extremo leste da seção B-B' e sua total substituição por depósitos quaternários até a profundidade de, pelo menos, $90 \mathrm{~m}$, como comprovado por um volume expressivo de datações derivadas de seis testemunhos de sondagem, é fortemente sugestivo da presença de falha. A ocorrência de padrão de drenagem tipicamente retangular formada por segmentos retilíneos onde ocorre a passagem entre essas unidades sedimentares se constitui em elemento independente que reforça a proposição de contato por falha. A ocorrência de várias anomalias de drenagem relatadas no canal principal do rio Paracauari é condizente com esta hipótese.

A passagem entre depósitos quaternários tardios e a Formação Barreiras no extremo leste da seção B-B' ocorre de forma abrupta. É marcante que esta passagem brusca coincide com local onde um dos tributários principais do rio Paracauari sofre várias inflexões bruscas, formando segmentos retilíneos e fortemente ortogonais, caracterizando drenagem tipicamente retangular (ver setas na Figura 36B). Em particular, um dos lados de um grande retângulo formado por canal retilíneo de direção NW-SE ocorre imediatamente a leste da SEV 41 (setas amarelas na Figura 36B). Como não existe nenhuma outra evidência de lineamento morfoestrutural significativo em grande parte da extensão compreendida entre as SEVs 41 e 38, infere-se que o lineamento localizado imediatamente a leste da SEV 41 possa ser candidato à expressão superficial da falha detectada em subsuperfície nessa seção B-B'. A constatação de estratos quaternários à profundidade superior a 90 m nessa seção está em acordo com proposições anteriores de que o entorno do lago Arari (localizado no setor oeste da seção B-B') pode se constituir em importante depocentro da sedimentação quaternária do leste da ilha do Marajó (Rossetti et al. 2008b) 
O contato brusco entre a Formação Barreiras e os depósitos quaternários no extremo oeste da seção C-C' também mostra boa correspondência com lineamento morfoestrutural mapeado em superfície. O padrão ortogonal formado por este lineamento em combinação com vários outros presentes nesta área se constitui em anomalia de drenagem fortemente sugestiva de controle tectônico. Em particular, a interrupção brusca de lagos alongados relacionados ao bloqueio de drenagem antiga é condizente com esta hipótese. $\mathrm{O}$ fato da paleodrenagem ortogonal descrita pouco a leste da SEV 12 paralelizar lineamentos morfoestruturais do extremo oeste da seção C-C' permite sugerir controle tectônico também no desenvolvimento da drenagem pretérita. A abundância de paleocanais no terreno compreendido entre as SEVs 12 e 10 é concordante com sua atribuição a depósitos quaternários o que, juntamente com as demais evidências morfoestruturais, pode refletir que esta área tenha sofrido subsidência relativamente aos terrenos contendo a Formação Barreiras registrados nos extremos da seção. A grande concentração de lagos nesta área intermediária associados à sedimentação quaternária pode ser um reflexo dessa subsidência.

Embora não tenha sido possível relacionar nenhum lineamento morfoestrutural próximo à falha sugerida no extremo leste da seção C-C', a combinação de dados de SEV com testemunhos de sondagem suportam que neste ponto a sedimentação quaternária passa rapidamente à Formação Barreiras. Este local ocorre justamente no cruzamento com a porção intermediária da seção A-A', onde se descreveu boa correspondência entre falha interpretada em superfície e subsuperfície. 


\subsection{Radar}

Um elemento de significado primordial para a interpretação das seções de GPR foi o amplo reconhecimento de refletores de altas frequência e amplitude, que foram prontamente correlacionados por várias dezenas de quilômetros, se constituindo em marco estratigráfico chave. Estas características, aliadas ao fato destes refletores truncarem reflexões subjacentes e apresentarem relação de downlap e onlap com as reflexões sobrejacentes, permitem sua atribuição a uma superfície de descontinuidade estratigráfica regional de natureza erosiva. Tendo em vista o conhecimento geológico da área de estudo, o mais provável é que esta superfície corresponda à discordância marcada por paleossolo laterítico do topo da Formação Barreiras. Esta interpretação é condizente com o fato desses refletores a poucos metros da superfície em vários locais onde se pode observar afloramentos da Formação Barreiras onde esta discordância acha-se sempre presente em seu topo (Figura 30, ver também descrição do item 8.3). Adicionalmente, é interessante observar que fortes refletores com características similares foram previamente detectados em seções GPR adquiridas no topo de falésias contendo essa discordância associada com paleossolo laterítico em outras áreas de ocorrência da Formação Barreiras (Rossetti \& Góes, 2001; Rossetti et al. 2001; Rossetti, 2004). Apesar da forte concentração de óxidos e hidróxidos de ferro, a ação de raízes neste paleossolo, aliada ao fraturamento tectônico sugerido abaixo, possibilitou que as ondas eletromagnéticas atravessassem a barreira de ferrificação, sem atenuação do sinal de radar nos depósitos subjacentes.

As reflexões hiperbólicas localmente associadas com a superfície estratigráfica acima referida são condizentes com a presença de superfície irregular comumente associada às discordâncias. Em tais circunstâncias, ocorrem reflexões que assumem a forma de 
hipérboles à medida que a antena se afasta da área causadora deste efeito (Van Heteren et al. 1998). As reflexões caóticas, que são comumente observadas logo abaixo dos refletores relacionados à discordância, são totalmente compatíveis com a interpretação sugerida, já que uma das principais características da pedogênese é a homogeneização dos estratos. Passando o horizonte sob influência pedogenética, outros tipos de reflexões prevalecem, indicando a presença, além de estratos maciços, de sedimentos estratificados, como sugerido pelas reflexões paralelas a sub-paralelas, divergentes e côncavas, que podem ser relacionadas com estratos horizontais, estratos cruzados e depósitos em canal, respectivamente. A boa visualização destas reflexões na unidade A sugere abundância de litologias arenosas, já que pacotes argilosos têm a tendência de atenuar o sinal eletromagnético (p.e., Van Heteren et al. 1998; Ellefsen, 1999). Esta interpretação litológica, aliada às características da superfície estratigráfica acima interpretada, são compatíveis com o relacionamento da unidade A à Formação Barreiras, já que esta unidade contém elevado volume de arenitos maciços e estratificados, com abundantes feições de canal (p.e., Rossetti \& Truckenbrodt, 1989; Rossetti, 2000).

Considerando a associação da unidade A com a Formação Barreiras, os depósitos que ocorrem sobre a discordância são atribuídos aos Sedimentos Pós-Barreiras. Afloramentos da Formação Barreiras em vários locais do nordeste do Estado do Pará e Maranhão, bem como ao longo da costa nordeste brasileira, contém estratos formados no Quaternário Tardio, referenciados genericamente de Sedimentos Pós-Barreiras (p.e., Rossetti \& Truckenbrodt, 1989; Rossetti, 2004; Rossetti et al. no prelo). Estudos cronológicos enfocando estratos sobre a Formação Barreiras na ilha do Marajó e Zona Bragantina revelaram somente idades quaternárias tardias (Tatumi et al. 2009). A presença de reflexões bem definidas nos depósitos correlacionados aos Sedimentos Pós-Barreiras também sugere 
abundância de sedimentos arenosos, o que é plenamente condizente com o conteúdo litológico descrito para esta unidade.

O sinal de radar homogêneo, formando padrão contínuo e horizontal, de todas as seções que se estendem do lago São Luís ao lago Arari (Figuras 49) devem ser interpretadas com cautela. De acordo com os testemunhos de sondagem tem-se sugerido que esta área contém somente estratos quaternários tardios (Rossetti et al. 2008b; Miranda et al. 2009; Castro et al. 2010; Rossetti, 2010). Contrariamente aos demais Sedimentos PósBarreiras que se sobrepõem à Formação Barreiras na porção oriental da área de estudo, esses estratos são dominados por litologias argilosas que contém, esporadicamente, corpos arenosos delgados com volumes variáveis de água salobra ou salgada (Gonzalez, 1978; Kobayashi, 1979; Porsani, 1981). Estas se constituem em características altamente favoráveis ao bloqueio de ondas eletromagnéticas emitidas por GPR (p.e., Van Heteren et al. 1998). Então, é possível que os sinais homogêneos das seções adquiridas sobre estes depósitos reflitam esta condição de subsuperfície. Apesar da ausência de sinal de radar, este dado é interessante, porque reflete condição de sedimentação totalmente distinta de sedimentos quaternários correlacionáveis que ocorrem sobre a Formação Barreiras na porção oriental da área de estudo.

Portanto, a não distinção de reflexões, sistematicamente, em todas as seções GPR adquiridas em depósitos quaternários localizados entre os lagos São Luís e Arari é interpretada como decorrente de sua constituição dominantemente argila, aliada ao conteúdo de água salobra e salgada. O mais provável é que esta área contenha depósitos quaternários mais espessos que os depósitos arenosos correlatos verificados sobre a Formação Barreiras nas demais seções GPR analisadas. A hipótese mais lógica é que o espessamento de estratos nessa área deva-se ao aumento da taxa de sedimentação neste 
setor da ilha decorrente da geração de espaço acomodacional, provavelmente por subsidência tectônica. A não detecção da Formação Barreiras nessa área, sugerida por dados de superfície e de testemunhos de sondagem, e o rápido desaparecimento do horizonte altamente resistivo relacionado à discordância do topo dessa unidade, por vezes, coincidente com a presença de lineamentos morfoestruturais, reforça esta proposição. Sugere-se, portanto, que neste setor da ilha a Formação Barreiras sofreu deslocamento em, pelo menos, vários metros, proporcionando a criação de novo espaço para acomodar uma sucessão mais expressiva, e litologicamente mais variável, de Sedimentos Pós-Barreiras do que a verificada na porção oriental da área de estudo. Como sugerido em trabalhos prévios, a retomada da sedimentação quaternária na ilha do Marajó ocorreu após longo tempo de estabilidade tectônica que se sucedeu à deposição da Formação Barreiras no Mioceno (Rossetti \& Valeriano, 2007; Rossetti, 2007; Rossetti et al. 2008).

De grande interesse para reforçar a hipótese tectônica acima proposta é a análise da natureza irregular das reflexões relacionadas à discordância do topo da Formação Barreiras. Em parte, isto se deve à própria característica erosiva desta superfície, formada por exposição subaérea e desenvolvimento de solo durante período prolongado de não deposição associado com a queda do nível do mar tortoniana (Rossetti, 2006). Entretanto, o fato dessa superfície indicar deslocamentos localmente exagerados leva a hipotetizar que sua origem não decorre somente de processos erosivos. A ocorrência de locais onde esta discordância é representada por segmentos de reflexões bruscamente interrompidos e deslocados sugere movimentação vertical dos estratos. O fato de, em muitos casos, reflexões subjacentes a estes segmentos serem concordantes com estes deslocamentos, condizem com esta interpretação. Este fato, associado a áreas delgadas livre de reflexões ou com reflexões caóticas onde ocorre interrupção brusca e deslocamento vertical desses 
segmentos de reflexões, sugere a presença de falhas. Muitos trabalhos têm interpretado planos de falha em seções GPR por meio de refletores interrompidos seguindo este mesmo padrão (p.e., Meschede et al. 1997; Van Heteren et al. 1998; Basson et al. 2002; Rashed et al. 2003; Ferry et al. 2004; Patidar et al. 2008). A presença de segmentos escalonados é condizente com sucessões de falhas com deslocamento por gravidade. Conjuntos de falhas acham-se arranjadas de forma a configurar conjugados que lembram estruturas "em flor" (Figura 44C, D) (Barbosa Filho et al. 1989; Travassos \& Barbosa Filho, 1990; Silva 2005). Estudos anteriores já haviam detectado falhas em seções de GPR que registram a Formação Barreiras e os Sedimentos Pós-Barreiras na Zona Bragantina (p.e., Rossetti et al. 2001; Rossetti, 2004). Adicionalmente, muitos estudos recentes vêm registrando a presença de falhas nesses depósitos no nordeste do Brasil (p.e., Bezerra \& Vita-Finzi, 2000, Saadi \& Torquato, 1992, Bezerra et al. 2005; Furrier et al. 2006; Bezerra et al. 2008; Nogueira et al. 2010; Rossetti et al. no prelo). O fato da unidade A apresentar maior volume de segmentos deslocados verticalmente leva a interpretar que esta unidade foi mais fortemente afetada por deformação que a unidade B.

Outra feição observada nas seções GPR que merece ser destacada são as reflexões fortemente ondulantes, com geometria em mound ou convexas para cima, que ocorrem em associação à sub-unidade A1. O fato desta sub-unidade ser lateralmente descontínua e desaparecer bruscamente, ser sobreposta por reflexões que terminam contra ela em onlap, e ser delimitada em seu topo por reflexões de altas freqüência e amplitude, sugere que este conjunto de estratos pode se constituir em uma unidade estratigráfica à parte, seja inserida na Formação Barreiras, seja mais antiga.

Embora a possibilidade da sub-unidade A1 ser mais antiga não possa ser totalmente descartada com base no estudo presente, é interessante lembrar que trabalhos anteriores 
subdividiram a Formação Barreiras em, pelo menos, três unidades estratigráficas, formadas por flutuações de alta freqüência do nível do mar relativo (Rossetti, 2000; Rossetti \& Santos, 2004). Neste último trabalho, realizado na Sub-bacia de Cametá, porção sudoeste do Sistema de Graben do Marajó, os autores descreveram falhas e dobras, que foram relacionadas com deformação sin-sedimentar associada com a reativação de falhas tectônicas. Trabalho mais recente realizado no litoral do Estado da Paraíba também registram falhas e dobras amplas na Formação Barreiras (p.e., Rossetti et al. no prelo). Levando em consideração estes artigos, é possível relacionar as reflexões ondulantes detectadas na base da unidade A a estratos dobrados. Seções de radar que amostram a Formação Barreiras no litoral paraense já haviam detectado este mesmo padrão de reflexões ondulantes (Rossetti, 2004). Embora, até o momento, não existam evidências de campo que comprovem deformação por compressão afetando estratos da Formação Barreiras, modelo tectônico (Costa et al. 1996) prevê este tipo de deformação em associação com zonas de transcorrência para o litoral paraense. Adicionalmente, modelo compressivo associado com zonas de transcorrência tem também sido apresentados para justificar as dobras da Formação Barreiras no nordeste do Brasil (Bezerra et al. 2008).

Levando em consideração os dados acima apresentados, é possível que as reflexões ondulantes da sub-unidade A1 correspondam a estratos dobrados formando sinclinais e anticlinais amplas. Esta deformação dúctil pode ter ocorrido sin-deposicionalmente, afetando somente uma parte da Formação Barreiras, correspondente à porção basal das seções GPR, sem atuar nos estratos sobrejacentes, depositados posteriormente ao evento deformacional. Entretanto, a associação dessas possíveis dobras com falhas, inclusive na sessão quaternária, atesta recorrências de esforços deformacionais com o tempo. 


\subsection{Mecanismo gerador de estruturas tectônicas na ilha do Marajó}

O leste da ilha do Marajó insere-se em uma área tida como tectonicamente estável a nordeste da Sub-Bacia do Limoeiro, na margem oriental do Sistema de Graben do Marajó. Apesar deste contexto, as estruturas tectônicas incluindo falhas e, possivelmente, dobras, registradas neste trabalho, revelam que essa área pode ter sido sujeita a instabilidades expressivas que afetaram a sedimentação miocena e quaternária. Levando isto em consideração, torna-se apropriada uma discussão sobre o mecanismo gerador de tectonismo em um tempo geológico bastante recente nessa área de margem continental passiva. Três fatores potencialmente mais relevantes incluem: tectônica andina, tectônica gravitacional provocada pela sobrecarga sedimentar no leque submarino do Amazonas, e reativação de estruturas relacionadas com o rifte marginal.

\subsubsection{Hipótese de associação com a tectônica andina}

Vários estudos têm sugerido que movimentações tectônicas na cadeia andina são responsáveis por eventos neotectônicos em áreas da planície amazônica, pelo menos em sua porção oeste (p.e., Lima, 1988; Campos \& Teixeira, 1988; Dumont et al. 1991; Souza-Filho et al. 1999; Campbell et al. 2010). É interessante verificar que existe um crescente registros de feições neotectônicas em várias áreas amazônicas, inclusive com efeito no padrão de drenagem atual e passado (Sternberg, 1950; Bemerguy, 1997; Franzinelli \& Igreja, 2002; Bezerra, 2003; Silva, 2005; Almeida-Filho \& Miranda, 2007; Rossetti \& Valeriano, 2007).

A cadeia andina resulta da subducção de crosta oceânica do leste das placas de Nazca e Antártica sob a crosta continental do oeste da placa sulamericana. Apesar de várias 
orogenias pré-andinas desde o Proterozóico, os Andes modernos iniciaram seu soerguimento no Triássico com a quebra do Pangea (p.e., Brito Neves, 1992, 1999; Pimentel \& Fuck, 1992; Rogers, 1996; Brito Neves \& Campos Neto, 1998). Entretanto, estima-se que suas elevações eram de apenas 1,3 km entre 15 e $20 \mathrm{Ma}$ (Gregory-Wodzicki, 2000) e < 2 km há 10 Ma (Gregory et al. 1998). Entre 10 e 6 Ma, a cadeia andina sofreu forte acréscimo em altitude da ordem de 1,5 e 3,5 km (Garzione et al. 2008). A deformação neste período afetou principalmente sua porção central durante o evento conhecido como Quechua II (Garzione et al. 2008; Hungerbühler et al. 2002). Como compensação ao soerguimento, bacias de frente de arco (foreland) localizadas a leste dos Andes sofreram subsidência, com consequente transgressão (Hernadez et al. 2005; Hulka et al. 2006).

Durante grande parte do período de forte soerguimento da cadeia andina do final do Mioceno, a margem equatorial brasileira apresentava-se sob condições estáveis, o que fica evidenciado pelo desenvolvimento da discordância regional associada a paleossolo laterítico do topo da Formação Barreiras (Rossetti, 2004, 2006). Relacionamentos estratigráficos apresentados nesses trabalhos sugerem que essa discordância teve início no Tortoniano, em associação à queda do nível do mar global. Dados não publicados enfocando datações isotópicas de (U-Th)/He de goetitas intempéricas de paleossolo laterítico do topo da Formação Barreiras no norte e nordeste do Brasil sugerem início de pedogênese a partir de 17,86 Ma (Rossetti, informação verbal), o que está em acordo com idades (U-Th)/He e ${ }^{40} \mathrm{Ar} /{ }^{39} \mathrm{Ar}$ obtidas na porção sul da Província Borborema (Lima, 2008). Tendo-se me vista essas informações, é problemática tecer correlações entre eventos de soerguimento dos Andes com atividades tectônicas na área de estudo. Costa et al. (1996) também descartaram a possibilidade de que o quadro neotectônico amazônico tenha qualquer relação direta com o desenvolvimento orogênico andino. Portanto, considerando- 
se a discussão acima, e também a localização da área de estudo a uma distância superior a $3.000 \mathrm{~km}$ dos Andes em linha reta, o mais provável é que a deformação andina tenha tido papel secundário na geração das estruturas neotectônicas aqui registradas.

\subsubsection{Hipótese associação com tectônica gravitacional}

Tectônica gravitacional causada por sobrecarga sedimentar no cone do Amazonas é outro fator a ser ponderado, considerando que a área de estudo localiza-se imediatamente a sudeste da Bacia da Foz do Amazonas. Desde o Mioceno, um grande volume de sedimentos vem se acumulando nessa bacia. Estes sedimentos formam um leque submarino que se estende por uma distância de aproximadamente $700 \mathrm{~km}$, desde a quebra da plataforma até a profundidade de aproximadamente $4800 \mathrm{~m}$, compreendendo uma área de aproximadamente $360.000 \mathrm{~km}^{2}$ (Rimington et al. 2000; Silva et al. 1999). Durante os estágios iniciais de seu desenvolvimento, a taxa de sedimentação foi muito baixa, da ordem de $0,05 \mathrm{~m} / \mathrm{ka}$ (Figueiredo et al. 2009). Entretanto, com o tempo, houve aumento gradativo desta taxa, sendo que do Pleistoceno até o presente, ela aumentou em, pelo menos, quatro vezes, passando para uma média de 1,22 $\mathrm{m} / \mathrm{ka}$, e chegando até $5 \mathrm{~m} / \mathrm{ka}$ no Pleistoceno Tardio (Rimington et al. 2000).

O grande volume de sedimentos acumulados no cone do Amazonas forma uma sucessão sedimentar de mais de $9000 \mathrm{~m}$ de espessura. Um número crescente de trabalhos vem atribuindo a ocorrência de falhas e dobras nessa área à instabilidade gravitacional causada por essa imensa carga sedimentar (p.e., Gaullier et al. 1993; Bradão \& Feijó, 1994; Silva et al. 1999; Oliveira, 2005; Reis et al. 2005, 2008; Silva, 2008). De acordo com esses autores, à medida que o sedimento foi sendo acumulado, instabilidades do talude e/ou 
deslizamentos gravitacionais da cobertura sedimentar provocada pela presença de níveis de argilas superpressurizadas, teria causado deformação superficial extensiva da cobertura sedimentar. Tectônica gravitacional tem sido bem registrada na literatura internacional (p.e., Jackson et al. 1994; Mohriak et al. 1995; Cohen \& McClay, 1996; Morley \& Guerin, 1996; Hopper et al. 2002; Vendeville \& Gaullier, 2003; Rowan et al. 2004). Em particular, este processo tem sido ativo nas bacias marginais da margem equatorial brasileira desde o Cretáceo (Bruno, 1987; Cobbold et al. 2004), similarmente a muitas outras áreas da margem continental atlântica.

De forma geral, áreas dos leques submarinos proximais afetadas por tectônica gravitacional são dominadas por esforços distensivos, que gradam a esforços compressivos distalmente. Este modelo é diretamente aplicável ao leque do Amazonas, onde se registram falhas lístricas proximais e uma série de dobras e falhas reversas distais associadas com múltiplas frentes compressivas (Oliveira, 2005; Silva, 2008). De acordo com esses autores, as falhas são, por vezes, soterradas, mas podem atingir a superfície, causando desníveis de até $500 \mathrm{~m}$ na plataforma continental.

É possível hipotetizar que o forte tectonismo gravitacional existente na plataforma continental localizada imediatamente a norte/noroeste da ilha do Marajó poderia ter causado deformação da Formação Barreiras e dos Sedimentos Pós-Barreiras presentes na área de estudo. Entretanto, muitos autores defendem que a sedimentação desse leque teve início com o evento de rebaixamento do nível do mar tortoniano, quando o rio Amazonas passou a ter expressão transcontinental (p.e., Damuth \& Flood, 1985; Maslin et al. 2005; Figueiredo et al. 2009). Se considerarmos que as dobras formadas na Formação Barreiras são sin-sedimentares, como sugerido previamente nesta tese, então elas predatam o evento de tectonismo gravitacional do leque do Amazonas e, portanto, não poderiam ser 
relacionadas com este evento. Além disto, de acordo com o modelo de tectônica gravitacional, como acima mencionado, dobras são comumente esperadas na porção distal do sistema de leques, portanto sua ocorrência na ilha do Marajó seria completamente inesperada. Se a sobrecarga do leque do Amazonas tivesse qualquer efeito colateral na área de estudo, o esperado seria o prolongamento de esforços distensivos do leque proximal, com desenvolvimento de falhas normais. Embora a área de estudo tenha evidências de falhas, as orientações variáveis sugeridas pela análise de lineamentos morfoestruturais, com direcionamentos preferenciais para NW-SE, NE/SW e subordinados para E-W, NNE/SSW e NNW-SSE, não poderiam ser justificadas no contexto da tectônica do leque do Amazonas, já que nessa área dominam falhas lístricas de direção NW-SE (Silva, 2008), ou seja, perpendicular ao mergulho deposicional, como esperado no modelo de tectônica gravitacional. Portanto, a grande complexidade de orientações das falhas sugeridas para a área de estudo não pode ser justificada considerando-se apenas tectônica gravitacional.

\subsubsection{Hipótese de associação com rifteamento marginal}

Tendo-se em vista a discussão acima, o mais provável é que as estruturas tectônicas registradas na área de estudo sejam decorrentes de reativações relacionadas ao rifteamento marginal. Isto é proposto com base na integração dos dados aqui levantados com informações de literatura.

Assim, a margem equatorial brasileira experimentou várias fases de evolução tectônica, com deformação significativa no final do Jurássico/início do Cretáceo, quando houve o desenvolvimento de grabens e semi-grabens resultante de esforços distensivos associados ao rifteamento do Oceano Atlântico (Szatmari et al. 1987). Embora esforços 
extensivos tenham inicialmente prevalecido, movimentos transcorrentes com desenvolvimento de feições transtensivas e transpressivas passaram a ser mais importantes no Terciário (Matos, 2000). Com isto, bacias do tipo rifte evoluíram para fase pull-apart o que se deu em função da movimentação da placa sulamericana para W e NW (Hasui, 1990), evento que deixou reflexos em inúmeras outras áreas da margem brasileira (Saadi \& Torquato, 1992; Riccomini \& Assumption, 1999; Morais-Neto \& Alkmin, 2001; Bezerra et al. 2001, 2005, 2008; Furrier et al. 2006; Costa et al. 2001; Bezerra \& Vita-Finzi, 2000; Nogueira et al. 2010).

Com a abertura do Oceano Atlântico, houve o estabelecimento do Sistema de Graben do Marajó seguindo antigas zonas de fraqueza, relacionadas à forma ção de rifte prébrasiliano gerado por junção tríplice na foz do Amazonas (Bahia \& Abreu, 1985; Costa et al. 1996). Durante o Terciário e Quaternário, essa área experimentou domínio de movimentos de transcorrência (Szatmari et al. 1987; Hasui, 1990), quando foram reativadas estruturas pré-existentes relacionadas com o predomínio de falhas reversas NE-SW e falhas normais NE-SW, além de falhas transcorrentes dextrais ENE-WSW e NE-SW (p.e., Villegas, 1994; Costa \& Hasui, 1997; Costa et al. 1995, 2002; Bemerguy, 2002; Mantelli, 2008). Considerando a localização em área tipicamente plana, a presença de sedimentação terciária e quaternária de aproximadamente $4 \mathrm{~km}$ de espessura neste sistema de graben evidencia que o fator tectônico foi fundamental na geração de espaço acomodacional.

As direções preferenciais dos lineamentos morfoestruturais para NE-SW e NW-SE registradas no leste do da ilha do Marajó são plenamente compatíveis com as orientações principais das estruturas do Sistema de Graben do Marajó. Embora estando situada fora dos limites conhecidos para este sistema, os dados aqui apresentados levam a sugerir que a área de estudo pode ter sido afetada por reativações tectônicas relacionadas a ele. 
Informações de subsuperfície que possam auxiliar na visualização do arcabouço estrutural para o leste da ilha do Marajó são ainda escassas. Porém, tem sido sugerido que essa área pode conter bacias sedimentares profundas (Azevedo, 1991). Adicionalmente, com base na análise de dados gravimétricos, foi sugerida a presença de uma depressão profunda e alongada na direção N-S, que coincide com o posicionamento do lago Arari (Rossetti et al. 2008b; Figura 51). Estes autores observaram que essa estrutura prolonga-se costa afora, onde se conecta com a Sub-bacia de Mexiana, localizada no extremo norte do Sistema de Graben do Marajó.

Portanto, a hipótese de relacionamento das estruturas tectônicas registradas neste trabalho com a dinâmica de evolução do Sistema de Graben do Marajó aparece como a mais provável. As dobras sugeridas na porção inferior das seções de GPR seriam facilmente explicadas sob tectônica transcorrente, dada sua associação natural com esforços transpressivos. Se considerarmos a possibilidade dos estratos dobrados pertencerem à Formação Barreiras, e que ocorre seu desaparecimento para cima nas seções, então se pode sugerir que este tipo de esforço ocorreu no Mioceno. Após este período, prevaleceram esforços transtensivos que resultaram em falhas na Formação Barreiras. Parte dessas falhas pode ter se desenvolvido juntamente com as dobras, porém o fato da discordância do topo dessa unidade ser deslocada frequentemente, sugere retorno da deformação após o Mioceno.

Embora menos freqüente, o prolongamento de algumas falhas para cima nos Sedimentos Pós-Barreiras é consistente com reativações contemporâneas ou posteriores à deposição desses depósitos, ou seja, no final do Pleistoceno-Holoceno. O fato da ilha do Marajó se constituir em uma das oito zonas sismogenicamente ativas da região amazônica, 
com registro de terremotos de intensidade moderada, i.e., magnitude $\sim 4,8$ na escala Richter (Miotto, 1993), revela que essas falhas podem ainda estar em atividade.

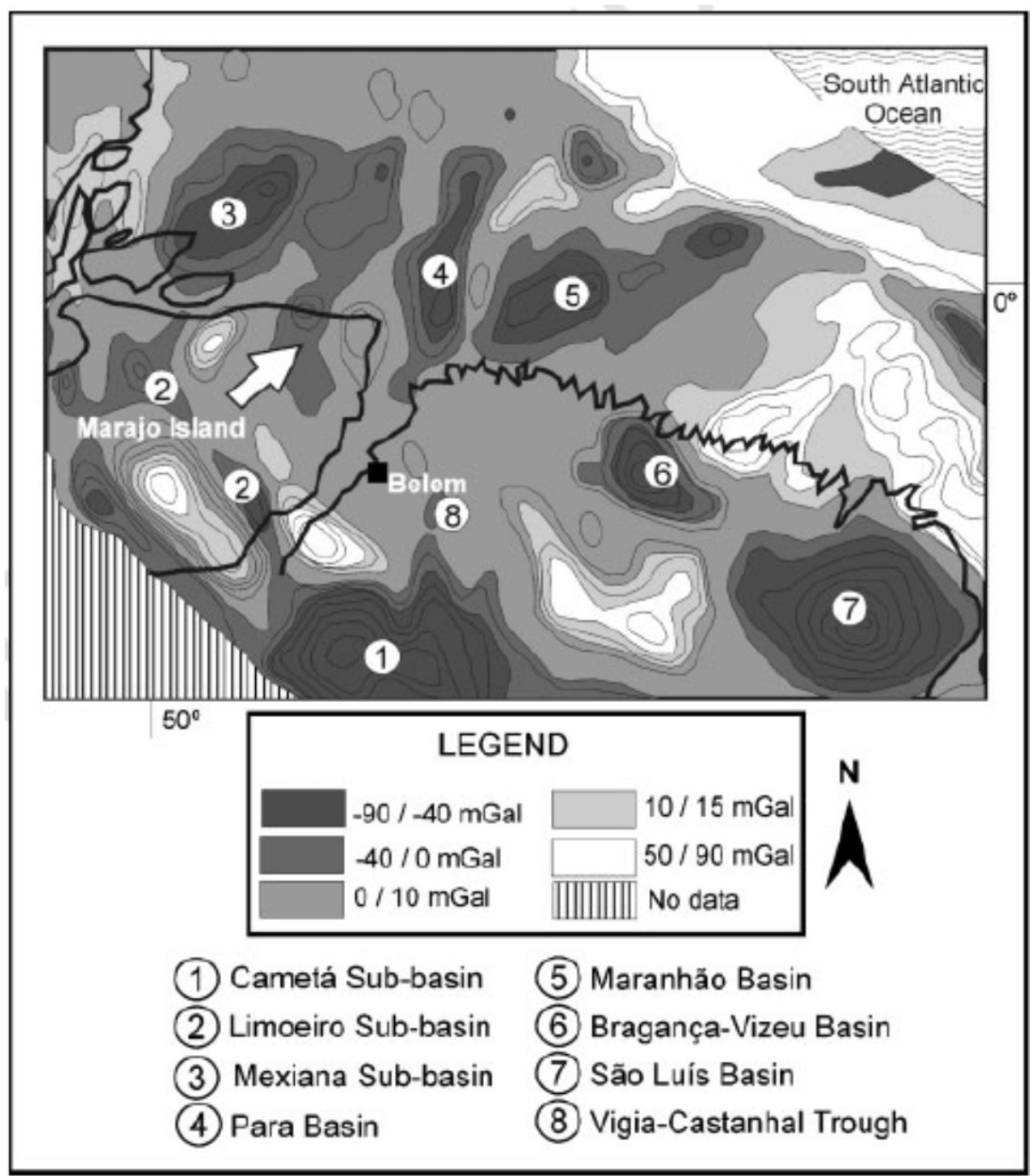

Figura 51 - Mapa de anomalias de Bouguer na margem nordeste brasileira (segundo Rossetti, 2008b). 


\section{CONCLUSÕES}

O estudo de superfície e de subsuperfície aplicando análise morfoestrutural e geofísica (SEV e GPR) na porção leste da ilha do Marajó levou ao registro de falhas e dobras tectônicas em associação com depósitos miocenos e quaternários, correspondentes à Formação Barreiras e Sedimentos Pós-Barreiras, respectivamente.

Considerando que as litologias da área de estudo são pouco variáveis, pode-se sugerir que a abundância de anomalias de drenagem presentes nas três bacias analisadas teve controle tectônico. Esta conclusão foi reforçada pela presença de lineamentos morfoestruturais com direcionamentos principais NW-SE e NE-SW e subordinado E-W e NNE-SSW/NNW-SSE, ao quais coincidem com sistemas de falhas registrados em muitas outras áreas da região amazônica. A análise morfoestrutural revelou, ainda, que lineamentos NW-SE predatam lineamentos NE-SW.

Terrenos representativos da Formação Barreiras, por serem mais antigos, mostram maior densidade de lineamentos, enquanto que terrenos onde os Sedimentos Pós-Barreiras predominam em superfície contêm volume de lineamentos relativamente menor, por registrar apenas estruturas formadas mais recentemente e, portanto, com domínio de lineamentos NE-SW.

Valores elevados de resistividade (i.e., na ordem de $13.000 \Omega \mathrm{m}$ ) foram relacionados com paleossolo laterítico associado com a discordância do topo da Formação Barreiras, bem como com estratos cimentados por ferro que ocorrem imediatamente subjacentes a essa discordância. Com base nesta interpretação, pode-se concluir que a Formação Barreiras acha-se aflorante ou ocorre imediatamente abaixo da superfície nas porções leste 
e sudeste da área de estudo, correspondentes às adjacências das cidades de Cachoeira do Arari, Ponta de Pedras, Soure, Joanes e Salvaterra. Por outro lado, terrenos representados em superfície por estratos com idades pleistocênicas tardias e holocênicas apresentaram condutividade, em geral, alta (i.e., $<90 \Omega \mathrm{m}$ ), o que sugere domínio de litologias lamosas e de depósitos heterolíticos.

Os dados de SEV revelaram, ainda, vários locais com registro de contatos bruscos entre a Formação Barreiras e os Sedimentos Pós-Barreiras. Muitos destes contatos coincidem com a ocorrência de lineamentos morfoestruturais, o que levou à sua associação a falhas tectônicas.

A análise de seções de GPR levou ao reconhecimento de refletores de altas freqüências e amplitude, que foram prontamente correlacionados por várias dezenas de quilômetros, se constituindo em marco estratigráfico chave. Estas características, aliadas ao fato destes refletores truncarem reflexões subjacentes e apresentarem relação de downlap e onlap com as reflexões sobrejacentes, permitiram sua atribuição a uma superfície de descontinuidade estratigráfica regional de natureza erosiva. A integração desta informação com dados geológicos e de resistividade levou à conclusão de que este marco corresponde à discordância com paleossolo laterítico do topo da Formação Barreiras.

O reconhecimento da discordância do topo da Formação Barreiras levou à identificação de duas unidades de radar, principalmente dominantes na porção leste e sudeste da área de estudo: uma inferior, correspondente à Formação Barreiras e a outra superior, correspondente aos Sedimentos Pós-Barreiras. Nessas áreas, os Sedimentos PósBarreiras são, em geral, delgados. No restante da área para oeste e norte, não houve identificação dessas unidades de radar, sendo que todas as seções de GPR revelaram 
ausência de refletores. Como os dados de testemunhos de sondagem revelam que esta área é dominada por depósitos quaternários, esta característica foi relacionada ao domínio de argila e presença de água intraestratal salobra e/ou salgada, características que costumam bloquear o sinal de GPR.

O brusco desaparecimento de refletores relacionados com a discordância do topo da Formação Barreiras para leste e norte da área de estudo, onde esta unidade é substituída por estratos quaternários, levou à conclusão de que, muito provavelmente, estas localidades, sofreram subsidência, tornando-se palco de sedimentação renovada no Quaternário. Esta conclusão é reforçada pela interpretação nas seções de radar de rompimentos bruscos e deslocamentos verticais exagerados da discordância do topo da Formação Barreiras, bem como dos estratos imediatamente subjacentes, o que levou a sugerir a presença de falhas.

Embora a Formação Barreiras registre o maior volume de feições relacionadas a falhas nas seções de GPR, pode-se identificar que, localmente, ocorre continuidade destas para cima, ou seja, em direção aos Sedimentos Pós-Barreiras, o que levou à conclusão de que reativações tectônicas ocorreram concomitantemente ou posteriormente à sua deposição.

O fato da Formação Barreiras registrar maior volume de falhas levou a interpretar que esta unidade foi mais fortemente afetada por deformação tectônica que os Sedimentos PósBarreiras.

Além de falhas, a base da Formação Barreiras contém reflexões amplamente ondulantes, que foram relacionadas com dobras sinclinais e anticlinais. A ocorrência dessas feições somente na base da Formação Barreiras levou a propor mecanismo de deformação atuante durante a sedimentação desta unidade, ou seja, ainda no Mioceno. 
A ocorrência associada de falhas e dobras nos estratos miocenos e de falhas nos sedimentos quaternários deve-se, muito provavelmente, a reativações tectônicas de falhas transcorrentes ligadas aos sistemas riftes da margem equatorial brasileira.

Os bons resultados alcançados pela integração de dados morfoestruturais com informações geofísicas aplicando-se SEV e GPR no leste da ilha do Marajó levam a propor a continuidade deste tipo de estudo para melhorar a reconstituição de sua história tectonosedimentar em tempo miocenos e quaternários. 


\section{REFERÊNCIAS BIBLIOGRÁFICAS}

Almeida, F. F. M. 1967. Origem e evolução da Plataforma Brasileira. Rio de Janeiro: DNPM/DGM. Boletim, n. 241.

Almeida Filho, R. \& Miranda, F. P. 2007. Mega capture of the Rio Negro and formation of the Anavilhanas Archipelago, Central Amazônia, Brazil: evidences in an SRTM digital elevation model. Remote Sensing of Environment, 10: 387-392.

Arai, M.; Uesugui, N.; Rossetti, D. F.; Góes, A. M. 1988. Considerações sobre a idade do Grupo Barreiras no nordeste do Estado do Pará. In: Cong. Bras. Geol., 35, Anais....SBG. 2: 738-752.

Avenius, Cg. 1988. Cronostratigraphic study of the post-rift/sin-rift unconformity, Marajó Rift system. Belém. Texaco/Canada Report, 6p.

Azevedo, R. P. 1991. Tectonic Evolution of Brazilian Equatorial Continental Margin Basins. Tese de doutorado, Royal School of Mines Imperial College, London, 412p.

Bahia, V. E. 2003. Estudo hidrogeológico da área localizada entre o depósito de lixo metropolitano de Belém (Aurá) e o Lago Água Preta. Belém (PA). CPGG-UFPA. 117p. (Dissertação de Mestrado).

Baker, P. A.; Seltzer, G. O.; Fritz, S. C., Dunbar, R. B.; Grove, M. J.; Tapia, P. M.; Cross, S. L.; Rowe, H. D.; Broda, J. P. 2001. The history of South American tropical precipitation for the past 25,000 years. Science, 291: 640-643.

Barbosa Filho, C. M.; Teixeira, L. B.; Travassos, W. A. S. Tectonismo terciário na área do Tapajós. In: Congresso Brasileiro de Geofísica, 1, 1989, Rio de Janeiro. Anais... Rio de Janeiro: SBGf, 1989, v. 3, p. 1252- 1259. 
Barbosa, T. M. F. 2003. Dinâmica dos sistemas de produção familiares da ilha do Marajó: o caso do município de Cachoeira do Arari. Belém (PA). CPCA-UFRA. 139p. (Dissertação de Mestrado).

Basson, U.; Ben-Avraham, Z.; Garfunkel, Z.; Lyakhovsky, V. 2002. Development of recent faulting in the southern Dead Sea Rift according to GPR imaging. European Geosciences Union (EGU) Stephan Mueller Special Publication Series, 2: 35-48.

Behling, H. 2001. Late Quaternary environmental changes in the Lagoa da Curuça region (eastern Amazonia, Brazil) and evidence of Podocarpus in the Amazon lowland. Vegetation History and Archaeobotany, 10: 175-183.

Behling, H. \& Costa, M. L. 2000. Holocene environmental changes from the Rio Curuá record in the Caxiuanã region, eastern Amazon Basin. Quaternary Research, 53: 369377.

Bello, A. M. A.; Makinde, V.; Coker, J. O. 2006. Geostatistical analyses of accuracies of geologic sections derived from interpreted vertical electrical soundings (VES) data: an examination based on VES and borehole data collected from the northern part of Kwara State, Nigeria. Journal of American Science, 6: 24-31.

Bemerguy, R. L. 1997. Morfotectônica e evolução paleogeográfica da região da calha do Rio Amazonas. Belém (PA). CPGG-UFPA. 200p. (Tese de Doutorado).

Bemerguy, R. L. 1981. Estudo Sedimentológico dos Paleocanais da Região do Rio Paracauari, Ilha do Marajó - Estado do Pará. Belém (PA). NCGG-UFPA. 95p. (Dissertação de Mestrado).

Bemerguy, R. L. \& Costa, J. B. S. 1991. Considerações sobre o sistema de drenagem da Amazônia e sua relação com o arcabouço tectono-estrutural. Belém. Bol. Museu Paraense Emílio Goeldi. Série Ciências da Terra (3): 75-97. 
Bemerguy, R. L.; Costa, J. B. S.; Hasui, Y.; Borges, M. S. 1995. Tectônica e paleogeografia da calha do Rio Amazonas. In: Simp. Nac. Est. Tec. (SNET), 5. Gramado, 1995. Bol. Res. Exp.... Porto Alegre: SBG/RS e CPGQ/UFRGS, p: 419-420.

Bemerguy, R. L.; Costa, J. B. S.; Hasui, Y.; Borges, M. S.; Soares Jr., A. V. 2002. Strutural geomorphology of the Brazilian Amazon region. In: Klein, E. L.; Vasque, M. L.; Rosa, C. L. T. (eds.). Contribuição à Geologia da Amazônia. Belém. Soc. Bras. Geol., Núcleo Norte, p. 245-258.

Bemerguy, R.; Rocha, F.; Costa, J.; Borges, M.; Silva Junior, O. 2003. Cartografia Digital Aplicada à Integração dos Elementos Geomorfológicos da Ilha de Marajó. In: X Simp. Bras. de Geografia Aplicada.

Beres, Jr. M. \& Haeni, F. P. 1991. Application of ground penetration radar methods in hydrogeological studies. Ground Water, 29: 375-386.

Berger, Z. 1994. Satellite Hydrocarbon Exploration: Interpretation and Integration Techniques. Berlin: Springer-Verlag-Heidelberg. 319p.

Bezerra, C. A. C. A. 1979. Eletrorresistividade aplicada ao estudo de água subterrânea no Município de Salvaterra - Marajó - Pará. Belém (PA). NCGG-UFPA. 58p. (Dissertação de Mestrado).

Bezerra, F. H. R.; Amaro, V. E.; Vita-Finzi, C.; Saadi, A. 2001. Pliocene-Quaternary fault control of sedimentation and coastal plain morphology in NE Brazil. Journal of South America Earth Sciences, 14: 61-75.

Bezerra, F. H. R.; Fonseca, V. P.; Vita-Finzi, C.; Lima Filho, F. P.; Saadi, A., 2005. Liquefaction-induced structures in Quaternary alluvial gravels and gravels sediments, NE Brazil. In: Obermeier, S. F. (ed.), Paleoliquefaction and Appraisal of Seismic Hazards. Engineering Geology, Special Issue, 76: 191-208. 
Bezerra, F. H. R.; Neves, B. B. B.; Correa, A. C. B.; Barreto, A. M. F.; Suguio, K. 2008. Late Pleistocene tectonic-geomorphological development within a passive margin - the Cariatá trough, northeastern Brazil. Geomorphology, 97: 555-582.

Bezerra, F. H. R.; Vita-Finzi, C. 2000. How active is a passive margin? Paleoseismicity in northeastern Brazil. Geology, 28: 591-594.

Bezerra, P. E. L. 2003. Compartimentação morfotectônica do interflúvio Solimões-Negro. Belém (PA). CPGG-UFPA. (Tese de Doutorado).

Bloom, A. L. 1991. Geomorphology: A systematic analysis of late Cenozoic landforms. Englewood Chiffs: Prentice Hall. 532p.

Borges, W. R. \& Porsani, J. L. 2002. Investigações geofísicas na borda da bacia sedimentar de São Paulo. Rev. Bras. Geof., 20: 1-6.

Brandão, J. A. S. L. \& Feijó, F. J. 1994. Bacia da Foz do Amazonas. Bol.Geoc. Petrobras, 8: 91-99.

Bristow, C. S. 1995a. Internal geometry of ancient tidal bedforms revealed using ground penetrating radar. In: Flemming, B. W., \& Bartholomä A. (eds). Tidal signatures in modern and ancient sediments: International Association of Sedimentologists Special Publication, 24: 313-328.

Bristow, C. S. 1995b. Facies analysis in the Lower Greensand using ground-penetration radar. Journal of the Geological Society of Lodon, 152: 591-598.

Brito Neves, B. B. 1999. América do Sul: quatro fusões, quatro fissões e o processo acrescionário Andino. Rev. Bras. Geoc., 29: 379-392.

Brito Neves, B. B. 1992. O proterozóico médio no Brasil: ensaio do conhecimento e seus problemas. Rev. Bras. Geoc., 22: 449-461. 
Brito Neves, B. B;. Campos Neto, M. C.; Fuck, R. A. 1998. From Rodínia to Western Gondwana: an approach to the Brasiliano-PanAfricano cycle and orogenic collage. Episodes, 22:155-166.

Bruno, G. L. G. 1987. Argilocinese no Cone do Amazonas, Bacia da Foz do Amazonas. UFOP-Departamento de Geologia. Ouro Preto (MG). 103 p. (Dissertação de Mestrado).

Carrasquila, A.; Rijo, L.; Porsani, M. 1991. Estudo geofísico regional das águas subterrâneas na Ilha do Marajó - Pará. Rev. Bras. Geof., 9: 187-197.

Castro, D. L., Bezerra, F. H. R., Castelo Branco, R. M. G., 2008. Geophysical evidence of crustal-heterogeneity control of fault growth in the Neocomian Iguatu basin, NE Brazil. Journal of South American Earth Sciences, 26: 271-285.

Castro, D. L.; Carvalho, A. M.; Branco, R. M. G. C. 2005. Uso do GRP no estudo da estruturação interna de depósitos de eolianitos na região costeira de Uruoca - CE. Rev. Geol., 18: 245-254.

Castro, D. R.; Rossetti, D. F.; Pessenda, L. C. 2010. Facies, $\delta^{13} C, \delta^{15} N$ and $C / N$ analyses in a late Quaternary compound estuarine fill, northern Brazil. Marine Geology, 274: 135150.

Cavalcanti, G. M. L. 1979. Geofísica aplicada à prospecção de água subterrânea na área do Rio Paracauari - Ilha do Marajó - Pará. Belém (PA). NCGG-UFPA. 88p. (Dissertação de Mestrado).

Ceia, M. A. R.; Carrasquilla, A. A. G.; Travassos, J. M. 2004. Levantamento GPR em afloramentos turbidíticos da Bacia de Almada-BA. Rev. Bras. Geoc., 34: 411-418.

Cezar, G. S. da; Rocha, P. L. F. da; Buarque, A.; Costa, A. da. 2001. Two brazilian archaeological sites investigated by GPR: Serrano and Morro Grande. J. Appl. Geophys., 47: 227-240. 
Christofoletti, A. 1981. Geomorfologia Fluvial. Edgard Blücher. São Paulo. 313p.

Christofoletti, A. 1980. Geomorfologia. 2a . ed., Edgard Blücher. São Paulo. 190p.

Cobbold, P. R.; Mourges, R.; Boyd, K. 2004. Mechanism of thinskinned detachment in the Amazon Fan: assessing the importance of fluid overpressure and hydrocarbon generation. Marine and Petroleum Geology, 21: 1013-1025.

Cohen, H. A. \& McClay, K. 1996. Sedimentation and shale tectonics of the northwestern Niger Delta front. Marine and Petroleum Geology, 13: 313-328.

Cohen, M. C. L.; Behling, H.; Lara, R. J. 2005a. Amazonian mangrove dynamics during the last millennium: The relative sea-level and the Little Ice Age. Review of Palaeobotany and Palynology, 136: 93-108.

Cohen, M. C. L.; Souza Filho, P. W. M.; Lara, R. J.; Behling, H.; Angulo, R. J. 2005b. A model of Holocene mangrove development and relative sea-level changes on the Bragança Peninsula (Northern Brazil). Wetlands Ecology and Management, 13: 433443.

Cohen, M. C. L.; Lara, R. J.; Szlafsztein, C. F.; Dittmar, T. 2004. Mangrove Inundation and Nutrient Dynamics under a GIS perspective. Wetlands Ecology And Management, 12: $81-86$

Correa, P. R. S.; Peres, R. N.; Vieira, L. S. 1974. Solos. In: Brasil. Projeto Radam. Folha Belém SA-22. Rio de Janeiro. DNPM (Levantamento de Recursos Naturais), 5: 1-53.

Costa, A. F. \& Malagutti Filho, W. 2008. Caracterização estrutural e geofísica da lixeira de Porto Velho (RO). Geociências, 27: 229-236.

Costa, J. B. S; Bermerguy, R. L; Hasui, Y.; Borges, M. S. B. 2001. Tectonics and paleogeography along the Amazon River. Journal of South American Earth Sciences, 14: $335-347$ 
Costa, J. B. S; Bermerguy, R. L; Hasui, Y.; Borges, M. S. B.; Ferreira Jr., C. R. P.; Bezerra, P. E. L; Costa, M. L.; Fernandes, J. M. G. 1996. Neotectônica da Região Amazônica: aspectos tectônicos, geomorfológicos e deposicionais. Geonomos, 4: 23-44.

Costa, J. B. S.; Borges, M. S.; Bemerguy, R. L.; Fernandes, J. M. G.; Costa Jr., P. S.; Costa, M. L. 1993. A evolução cenozóica da região de Salinópolis, nordeste do Estado do Pará. São Paulo. Geociências. 12: 373-396.

Costa J. B. S. \& Hasui Y. 1997. Evolução geológica da Amazônia. In: Costa M. L. \& Angélica R.S. (eds.). Contribuições à Geologia da Amazônia. SBG, Núcleo Norte, p.1519.

Costa, J. B. S; Hasui, Y. Bermerguy, R. L. Soares Jr., A. V.; Villegas, J. M. C. 2002. Tectonics and paleogeography of the Marajó Basin, northern Brazil. An. Acad. Bras. Ciênc., 74: 519-531.

Costa, J. B. S.; Hasui, Y.; Borges, M. S.; Bemerguy, R. L. 1995. Arcabouço tectônico mesozóico-cenozóico da região da calha do Amazonas. Geociências. 14: 77-83.

Costa, M. L. 1991. Aspectos Geológicos dos Lateritos da Amazônia. Rev. Bras. Geoc., 21: 146-160.

Cunha, S. B. 1994. Geomorfologia Fluvial. In: Guerra, A. J. T. \& Cunha, S. B. (eds). Geomorfologia - uma atualização de bases e conceitos. Bertrand Brasil. Rio de Janeiro, $472 \mathrm{p}$.

Cutrim, A. O. \& Rebouças, A. C. 2005. Aplicação de Sondagem Elétrica Vertical na estimativa do topo e da espessura de unidades geológicas da Bacia do Paraná na Cidade de Rondonópolis-MT. Rev. Bras. Geof., 23: 89-98.

Dagallier, G.; Laitinen, A. L. Malartre, F.; Campenhout, I. P. A. M. V.; Veeken, P. C. H. 2000. Ground penetration radar application in a shallow marine Oxfordin limestone 
sequence located on the eastern flank of the Paris Basin, NE France. Sedimentary Geology, 130: 149-165.

Damuth, J. E. \& Flood, R. D. 1985. Amazon Fan, Atlantic Ocean. In: Bouma, A. H.; Normark, W. R.; Barnes, N. E. (eds.). Submarine Fans and Related Turbidite Systems. Frontiers and Sedimentary Geology, p:97-106.

Delcaillau, B.; Carozza, J. M.; Laville, E. 2006. Recent fold growth and drainage development: The Janauri and Chandigarh anticlines in the Siwalik foothills, northwest India. Geomorphology, 76: 241-256

Deffontaines, B. \& Chorowicz, J. 1991. Principles of drainage basin analysis from multisource data: application to the strutural analysis of the Zaire Basin. Tectonophysics, 194 (3): 237-263.

Departamento Nacional de Meteorologia (DNMET). 1992. Normas climatológicas. Brasília (DF). Relatório Interno.

Dominic, D. F.; Egan, K.; Carney, C.; Wolfe, P. J.; Boardman, M. R. 1995. Delineation of shallow stratigraphy using ground penetrating penetrating radar. J. Appl. Geophys., 33:167-175.

Dourado, J. C.; Kiang, C. H.; Malagutti Filho, W.; Braga, A. C. O. 2003. Utilização de radar de penetração no solo na detecção de estruturas artificiais rasas no solo. São Paulo, UNESP, Geociências, 22 (n. especial): 75-81.

Dourado, J. C.; Malagutti Filho, W.; Braga, A. C. O.; Nava, N. 2001. Detecção de cavidades utilizando gravimetria, eletrorresistividade e GPR. Geociências, 22 (N. Especial): $75-81$. 
Dumont, J. F.; Deza, E.; Garcia, F. 1991. Morphostructural provinces and neotectonics in the Amazonian lowlands of Peru. Journal of South Anierkun Earth Sciences, 4: 373381.

Ellefsen, K. J. 1999. Effects of layered sediments on the guided wave in crosswell radar data. Geophysics, 64: 1698-1707.

Etchebehere, M. L. C; Saadi, A. R.; Santoni, G., Casado, F. C.; Fulfaro, V. J. 2006. Detecção de prováveis deformações neotectônicas no vale do rio do Peixe, região ocidental paulista, mediante aplicação de índices RDE (Relação Declividade-Extensão) em segmentos de drenagem. Geociências, 25: 271-287.

Faustino, P. 2002. Marajó: Todo o exotismo da Amazônia Paraense. In: A síntese da Amazônia. Belém (PA). Governo do Pará, 12p.

Ferry, M.; Meghraoui, M.; Girard, J.F.; Rockwell, T.K.; Kozaci, O.; Akyuz, S.; Barka, A. 2004. Ground-penetrating radar investigations along the North Anatolian fault near Izmit, Turkey: Constraints on the right-lateral movement and slip history. Geology, 32: $85-88$

Figueiredo, J.; Hoorn, P.; Van Derven, P.; Soares, E. F. 2009. Late Miocene onset of the Amazon River and the Amazon Deep-sea Fan: evidence from the Foz do Amazonas Basin. Geology, 37: 619-622.

França, C. F. \& Souza Filho, P. W. M. 2003. Análise das mudanças morfológicas costeiras de médio período na margem leste da Ilha de Marajó (PA) em imagem Lansat. Rev. Bras. Geoc., 33 (2-suplemento): 127-136.

Franzinelli, E. \& Igreja, H. L. S. 2002. Modern sedimentation in the lower Negro River, Amazonas State, Brazil. Geomorphology, 44: 259-271. 
Freitas Filho, L. S. 2006. Prospecção de água subterrânea no Município de Novo Repartimento (PA) aplicando métodos elétricos e eletromagnéticos. Belém (PA). CPGfUFPA. 59p. (Dissertação de Mestrado).

Furrier, M.; Araújo, M. E.; Meneses, L. F. 2006. Geomorfologia e tectônica da Formação Barreiras no estado da Paraíba. Geologia USP, Série Científica, 6: 61-70.

Garzione, C. N.; Hoke, G. D.; Libarkin, J. C.; Withers, S.; MacFadden, B.; Elier, J.; Ghosh, P.; Mulch, A. 2008. Rise of the Andes. Science, 320: 1304-1307.

Gaullier, V.; Brun, J. P.; Guerin, G.; Leconu, H. 1993. Raft tectonics: the effects of residual topography below a salt décollement. Tectonophysics, 228:363-381.

Gawthorpe, R. L.; Collier, R. E. L.; Alexander, J.; Bridge, J. S.; Leeder, M. R. 1993. Ground penetrating radar: application to sandbody geometry and heterogeneity studies. In North, C. P. \& Prosser, D. J. (eds.). Characterization of Fluvial and Aeolian Reservoirs: Special Publication of the Geological Society of London, 73: 421-432.

Góes, A. M. \& Rossetti, D. F. 2001. Gênese da Bacia de São Luís-Grajaú. In: Rossetti, D. F; Góes, A.M.; Truckenbrodt, W (eds). O Cretáceo na Bacia de São Luís Grajaú. Museu Paraense Emílio Goeldi, Coleção. Friedrich Katzer: Belém, Brasil. p: 15-29.

Góes, A. M.; Rossetti, D. F.; Nogueira, A. C. R.; Toledo, P. M. 1990. Modelo deposicional preliminar da Formação Pirabas no nordeste do Estado do Pará. Boletim do Museu Paraense Emílio Goeldi, sér. Ciências da Terra 2, 2: 3-15.

Gonzáles, A. A. C. 1984. Estudo geofísico regional sobre água subterrânea da Ilha do Marajó - Pará - Brasil. Belém (PA). NCGG-UFPA. 143p. (Dissertação de Mestrado). 
Greaves, R. J.; Lesmes, D. P.; Lee, J. M.; Toksöz, M. N. 1996. Velocity variations and water content estimated from multi-offset, ground-penetrating radar. Geophysics, 61: 683-695.

Gregory-Wodzicki, K. M. 2000. Uplift history of the Central and Northern Andes: a review. Geological Society of America Bulletin, 112: 1091-1105.

Gregory-Wodzicki, K. M.; Mcintosh, W. C.; Velasquez, K. 1998. Climatic and tectonic implications of the late Miocene Jakokkota flora, Bolivian Altiplano. Journal of South American Earth Sciences, 11: 533-560.

Guimarães, P. P. D. 1983. Métodos sísmicos de refração e eletromagnético aplicados ao estudo de um paleocanal da Ilha do Marajó - Pará. Belém (PA). NCGG-UFPA. 90p. (Dissertação de Mestrado).

Hare, P. W. \& Gardner, T. W. 1985. Geomorphic indicators of vertical neotectonism along converging plate margins, Nicoya Peninsula, Costa Rica. In: Morisawa, M. \& Hack, J. T. (eds.), Tectonic Geomorphology. Proceedings of the 15th Annual Binghamton Geomorphology Symposium. Allen and Unwin, Boston, MA, p: 123-134.

Hasui, Y. 1990. Neotectônica e aspectos fundamentais da tectônica ressurgente no Brasil. In: $1^{\circ}$. Workshop sobre Neotectônica e Sedimentação Cenozóica Continental no Sudeste Brasileiro, Belo Horizonte, 1990. Anais ...Belo Horizonte: SBG/MG, p: 1-31.

Hasui, Y.; Haralyi, N. L. E. ; Costa, J. B. S. 1993. Megaestruturação pré-cambriana do território brasileiro baseada em dados geofísicos e geológicos. Geociências, 12: 7-32.

Hernandez, R. M.; Jordan, T. E.; Farjat A. D.; Echavarría, L.; Idlemand, B. D.; Reynolds, J. H. 2005. Age, distribution, tectonics, and eustatic controls of the Paranense and Caribbean marine transgressions in southern Bolivia and Argentina. Journal of South America Earth Sciences, 19: 495-512. 
Holmes, A. 1965. Principles of Physical Geology, 2. ed. London: Thomas Nelson. 1288p.

Hobbs, W. H. 1904. Lineaments of the Atlantic border region. Geological Society of America Bulletin, n. 15: 483-506.

Holbrook, J. \& Schumm, S. A. 1999. Geomorphic and sedimentary response of rivers to tectonic deformation: a brief review and critique of a tool for recognizing subtle epeirogenic deformation in modern and ancient settings. Tectonophysics, 305: 287-306.

Hooper, R. J.; Fitzsommons, R. J.; Grant, N.; Vendeville, B. C. 2002. The role of deformation in controlling depositional patterns in the south-central Niger Delta, West Africa. Journal of Structural Geology, 24: 847-859.

Howard, A. D. 1967. Drainage analysis in geologic interpretation: a summation. American Association of Petroleum Geologists Bulletin, 51: 2246-2259.

Hungerbühler, D.; Steinmann, J.; Winkler, W.; Seward, D.; Egüez, A.; Peterson, D.E.; Helg, U.; Hammer, C. 2002. Neogene stratigraphy and Andean geodynamics of southern Ecuador. Earth-Science Reviews, 57: 75-124.

Hulka, C.; Gräfe, K. U.; Sames, B.; Ubas, C.; Heubeck, C. 2006, Depositional setting of the middle to late Miocene Yecua Formation of the Chaco Foreland Basin, southern Bolivia. In: Hoorn, C. \& Vonhof, H. (eds.). New contributions on Neogene geography and depositional environments in Amazonia. Journal of South American Earth Sciences, 21: 135-150.

Igreja, H. L. S. 1992. Aspectos tectono-sedimentares do Fanerozóico do nordeste do Estado do Pará e noroeste do Maranhão, Brasil. Belém. CPGG/UFPA.192p. (Tese Doutorado). 
Instituto de Desenvolvimento Econômico Social do Estado do Pará (IDESP). 1986. Hidrogeologia da Região Oriental da Ilha do Marajó. Belém (PA). Relatório Interno, $97 \mathrm{p}$.

Instituto de Desenvolvimento Econômico Social do Estado do Pará (IDESP). 1974. Estudos integrados da Ilha do Marajó. Belém (PA). Relatório Interno, 333p.

Jackson, M. P. A.; Vendeville, B. C.; Schultz-Ela, D. D. 1994. Structural dynamics of salt systems. Annual Review of Earth and Planetary Sciences, 22: 93-117.

Jie, S.; Guangwen J.; Denghai, B.; Lifeng, W. 2003. Sounding of electrical structure of the crust and upper mantle along the eastern border of Qinghai-Tibet Plateau and its tectonic significance. Science in China (Series D), 46: 243-254.

Jol, H. M. \& Smith, D. G. 1991. Ground penetrating radar of northern lacustrine deltas: Canadian. Journal of Earth Sciences, 28: 1939-1947.

Kehew, A. E. 1995. Geology for engineers and environmental scientists. Prentice Hall. $574 p$.

Keller, E. A. \& Pinter, N. 1996. Active Tectonics: earthquakes, uplift, and landscape . New Jersey: Prentice-Hall. 338p.

Knoll, M. D.; Haeni, F. P.; Knight, R. J. 1991. Characterization of sand and gravel aquifer using ground-penetration radar, Cape Cod, Massachusetts. In: G. E. Mallard \& Aronson, D. A. (eds.). Geological Survey Toxic Waste Hydrology ProgramProceedings of Technical Meeting. Monterey, CA, Geological Survey Water Resources Investigations Report, 91-4034: 29-35.

Kobayashi, C. N. 1979. Métodos geofísicos aplicados à prospecção de água subterrânea no Município de Ponta de Pedras. Ilha do Marajó - Pará. Belém (PA). NCGG- UFPA. 93p. (Dissertação de Mestrado). 
Lima, M. G. 2008. A História do Intemperismo na Província Borborema Oriental, Nordeste do Brasil: Implicações Paleoclimáticas e Tectônicas. Natal (RN). PPGG-UFRN. 251p. (Tese de Doutoramento).

MacMechan, G. A.; Gaynor, G. C.; Szerbiak, R. B. 1997. Use of ground-penetrating radar for 3-D sedimentological characterization for clastic reservoir analogs. Geophysics, 62: 786-796.

Mantelli, L. R. 2008. Caracterização geomorfológica no sudoeste da Ilha do Marajó análise de modelos de elevação digital. São José dos Campos. INPE. Disponível em: http://urlib.net/sid.inpe.br/mtc-m17@80/2006/12.05.16.44

Mantelli, L. R. \& Rossetti, D. F. 2009. Significado tectônico de lineamentos de drenagem no sudoeste da ilha do Marajó. Rev. Bras. Geoc., 39: 1-13.

Marcelino, T. H.; Shiraiwa, S.; Borges, W. R.; Priante Filho, N.; Raiter, F. 2005. Ground Penetrating Radar (GPR) water level monitoring study of a mature transitional tropical forest. Act. Amaz, 35:1-15.

Marques Neto, R. \& Viadana, A. G. 2006. Morfotectônica na Bacia do Ribeirão Vermelho (São Thomé das Letras-MG): Avanços nos estudos neotectônicos no setor meridional do Estado de Minas Gerais. Estudos Geográficos, 4: 67-77.

Maslin, M.; Vilela, C.; Mikkelsen, N.; Grootes, P. 2005. Causes of catastrophic sediment failures of the Amazon Fan. Quaternary Science Reviews, 24: 2180-2193.

Matos, R. M. D. 2000. Tectonic Evolution of the Equatorial South Atlantic. In: Mohriak, W. \& Talwani M. (eds.). Atlantic Rifts and Continental Margins. Geophysical Monograph, 115: 331-354.

Maurya D. M.; Patidar,A. K.; Mulchandani, N.; Goyal, B.; Thakkar, M. G. S.; Bhandari, S.; Vaid, S. I.; Bhatt; N. P.; Chamyal, L. S. 2005. Current Science, 88: 231-240. 
Mendes, R. L. R. 2000. Geofísica aplicada ao mapeamento de aqüíferos da região metropolitana de Belém (PA). CPGf-UFPA. 72p. (Dissertação de Mestrado).

Mendes, R. L. R. \& Verma, O. P. 2002. Prospecção de água subterrânea na região de Belém (PA) através de perfilagem geofísica de poço e eletrorresistividade. Rev. Bras. Geoc., 32: 87-94.

Meschede, M.; Asprion, U.; Reicherter, K. 1997. Visualisation of tectonic structures in shallow-depth high-resolution ground-penetrating radar (GPR) profiles. Terra Nova 9: 167-170.

Mikkelsen, N.; Maslin, M.; Giraudeau, J.; Showers, W. J. 1997. Biostratigraphy and sedimentation rates of the Amazon Fan. In: Flood, R. D.; Piper, D. J. W.; Klaus, A.; Peterson, L. C. (eds.). Proceedings of the Ocean Drilling Program, Scientific Results, 155: 577-594.

Miotto, J. A. 1993. Sismicidade e zonas sismogênicas do Brasil. PhD thesis. Universidade Estadual Paulista, Rio Claro.

Mitchum, R. M. JR.; Vail, P. R.; Sangree, J. B. 1977. Seismic stratigraphy a global changes of sea level, part 6: stratigraphic interpretation of seismic reflection patterns in depositional sequences. In: C. E. PAYTON (ed.) Seismic stratigraphy-applications to hydrocarbon exploration. American Association of Petroleun Geologists Tulsa, Oklahoma, p. 117-133.

Miranda, M. C. C., Rossetti, D. F.; Pessenda, L. C. R. 2009. Quaternary paleoenvironments and relative sea-level changes in Marajó Island (Northern Brazil): facies $\delta 13 \mathrm{C}, \delta 15 \mathrm{~N}$ and C/N. Paleogeography, Paleoclimatology, Palaeoecology, 282:19-31.

Mohriak, W. U.; Macedo, J. M.; Castellani, R. T.; Rangel, H. D.; Barros, A. Z. N.; Latgé,M.; Ricci, J. A.; Mizusaki, A. M. P.; Szatmari, P.; Demercian, L. S.; Rizzo, J. G.; 
Aires, J. R. 1995. Salt Tectonics and Structural Styles in the Deep-water Province of the Cabo Frio Region, Rio de Janeiro, Brazil. In: Jackson, M. P. A.; Roberts, D. G.; Snelson, S. (eds.). Salt tectonics: a global perspective. AAPG Memoir, 65: 273-304.

Moraes-Neto, J. M. \& Alkimim, F. F. 2001. A deformação das coberturas terciárias do planalto da Borborema (PB-RN) e seu significado tectônico. Rev. Bras. Geoc., 31: 95106.

Moreira, C. A; Dourado, J. C.; Santos, K. 2007. Geofísica aplicada no estudo de área de lançamento de efluentes e tratamento de esgoto. São Paulo. UNESP. Geociências, 26: $17-25$.

Morley, C. K. \& Guerin, G. 1996. Comparison of gravity-driven deformation styles and behavior associated with mobile shales and salt. Tectonics, 15: 1154-1170.

Moura, M. V. M.; Lima Filho, F. P.; Reyes, Y. A. P.; Gauw, D. S.; Silva, D. A. S. S.; Souza, A. M. 2005, Perfilagem geofísica com GPR em um campo de dunas eólicas em Tibau do Sul - RN. Rev. Geol., 18: 150-165.

Nakashima, Y.; Zhou, H.; Sato, M. 2001. Estimation of groundwater level by GPR in area with multiple ambiguous reflections. Journal Appl. Geophys., 47: 241-249.

Neal, A. 2004. Ground-penetrating radar and its use in sedimentology: principles, problems and progress. Earth-Science Review, 66: 261-330.

Nogueira, F. C. C. 2004. Ground Penetrating Radar (GPR) aplicado ao estudo de estruturas tectônicas cenozóicas na Bacia Potiguar - NE do Brasil. Fortaleza (CE). UFC. 78p. (Dissertação de Mestrado).

Nogueira, F. C. C.; Bezerra, F. H. R.; Castro, D. L.; Branco, R. M. G. C. 2006. Radar de Penetração no Solo (GPR) aplicado ao estudo de estruturas tectônicas neógenas na Bacia Potiguar - NE do Brasil. Rev. Geol., 19: 23-33. 
Nogueira, F. C.; Bezerra, F. H. R.; Fuck, R. A. 2010. Quaternary fault kinematics and chronology in intraplate northeastern Brazil. Journal of Geodynamics, 49: 79-91.

Nunes, L. P. M. 2005. Caracterização geoelétrica da área de curtume localizada no Distrito de Icoaraci. Belém (PA). UFPA-CPGf. 76p. (Dissertação de Mestrado).

O’Leary, D. W.; Friedman, J. D.; Pohn, H. A. 1976. Lineament, linear, lineation: some proposed new standards for old terms. GSA Bulletin, 87: 1463-1469.

Oliva, A. \& Kiang, C. H. 2007. Mapeamento do lençol freático no Município de Rio Claro (SP) empregando a técnica de Sondagem Elétrica Vertical. São Paulo. UNESP. Geociências, 26: 27-34.

Oliveira, V. 2005. A tectônica Gravitacional no Cone do Amazonas: Compartimentação Estrutural e Mecanismos Controladores. Niterói (RJ). UFF-Departamento de Geologia. 83 p. (Dissertação de Mestrado).

Orellana, E. 1972. Prospeccion geoelétrica en corriente contínua. Madrid: Paraninfo. 523p.

Ouchi, S. 1985. Response of alluvial rivers to slow active tectonic movement. Geol. Soc. Amer. Bull., 96: 504-515.

Özürlan, G.; Candansayar, M. E.; Şahin, M. H. 2006. Deep resistivity structure of the Dikili-Bergama region, west Anatolia, revealed by two-dimensional inversion of vertical electrical sounding data. Geophysical Prospecting, 54: 187-197.

Paradella, W. R.; Cecarelli, I. C. F.; Luiz, S.; Oliveira, C. G.; Cottini, C. P.; Okida, R. 2003. Produção de carta topográfica por estereoscopia de alta resolução do Radarsat-1 integrada com dados TM-Landsat 5: uma avaliação para terrenos planos na Floresta Nacional de Tapajós (PA). Rev. Bras. Geoc., 33 (2-suplemento): 99-110. 
Paradella, W. R.; Santos, A. R.; Veneziani, P.; Morais, M. C. 2000a. Synthetic apertura Radar for geological applications in the moist tropics: experiences from the Brazilian Amazon Region. Rev. Bras. Geoc., 30: 538-542.

Paradella, W. R.; Santos, A. R.; Veneziani, P.; Sant'anna, M. V.; Morais, M. C. 2000b. Geological investigation using Radarsat-1 images in the tropical rain forest envionment of Brazil. Canadian Journal of Remote Sensig., 26: 81-89.

Pereira, A. J. 2001. Investigação da estratigrafia da Região Costeira de Maricá - Praia de Itaipuaçú (RJ), através do Ground Penetrating Radar (GPR). Niterói (RJ). UFF. (Dissertação Mestrado).

Pereira, A. J.; Gambôa, L. A. P.; Silva, M. A. M.; Rodrigues, A. R.; Costa, A. 2003. A utilização do Ground Penetrating Radar (GPR) em estudos de estratigrafia na praia de Iataipuaçú - Maricá (RJ). Rev. Bras. Geof., 21: 1-10.

Patidar, A. K.; Maurya, D. M.; Thakkar, M. G.; Chamyal, L. S. 2008. Evidence of neotectonic reactivation of the Katrol Hill Fault during late Quaternary and its GPR characterization. Current Science, 94: 338-346.

Payton, C. E. 1977. Seismic stratigraphy - applications to hydrocarbon exploration. Am Assoc. Pet. Geol. Mem., 26: 516p.

Peters, G.; \& Van Balen, R. T. 2007. Tectonic geomorphology of the northern Upper Rhine Graben, Germany. Global and Planetary Change, 58: 310-334

Pimentel, M. M. \& Fuck, R. A. 1992. Neoproterozoic crustal accretion in Central Brazil. Geology, 20: 375-379.

Porsani, J. L. 1999. Ground Penetrating Radar (GPR): proposta metodológica de emprego em estudos geológicosgeotécnicos nas regiões de Rio Claro e Descalvado - SP. Rio Claro (SP). IGCE-UNESP. 145 p. (Tese de Doutoramento). 
Porsani, M. J. 1981. Paleocanais, uma opção para prospecção de água subterrânea na Ilha de Marajó. Belém (PA). NCGG-UFPA. 109p. (Dissertação de Mestrado).

Porsani, J. L; Mendonça, C. A.; Bettencourt, J. S.; Hiodo, F. Y.; Silva J. E. 2004. Investigações GPR nos distritos mineiros de Santa Bárbara e Bom Futuro: Província Estanífera de Rondônia. Rev. Bras. Geof., 22: 57-68.

Rashed, M.; Kawamura, D.; Nemoto, H.; Miyata, T.; Nakagawa, K. 2003. Ground penetrating radar investigations across the Uemachi fault, Osaka, Japan. J. Appl. Geophys., 53: 63-75.

Rea, J. \& Knight, R. 1995. The use of Ground Penetration Radar for aquifer characterization: an example from southwestern British Columbia. In: Symposium on the Application of Geophysics to Engineering and Enviromental Problems, Orlando, Florida, p. 23-26.

Reis, A. T.; Gorini, C.; Mauffret, A. 2005. Implications of Salt-sediment Interactions for the Architecture of the Gulf of Lions deep-water sedimentary systems - Western Mediterranean Sea, Gulf of Lions Special Issue. Marine and Petroleum Geology, 22: 713-746.

Reis, A. T.; Silva, C. G.; Vendeville, B. C.; Perovano, R.; Ferreira, E.; Gorini, C.; Albuquerque, N.; Pederneiras, R.; Albuquerque, V.; Mattioda, J. 2008. Gravity-driven processes at the offshore Amazon Mouth Basin - Brazilian Equatorial Atlantic margin. Gravitational Collapse at Continental Margins: Products and Processes. The Geological Society of London. p. 15.

Rezende, W. \& Ferradaes, J. 1971. Integração geológica regional da bacia sedimentar da Foz do Amazonas. Belém. Petrobras/Departamento de Exploração. Relatório Interno, $27 \mathrm{p}$. 
Riccomini, C. \& Assumpção, M. 1999. Quaternary tectonics in Brazil. Episodes, 22: 221225.

Rimington, N.; Cramp, A.; Morton, A. 2000. Amazon Fan sands: implications for provenance. Marine and Petroleum Geology, 17: 267-284.

Rogers, J. J. W. 1996. History of Continents in the Past Three Billion Years. Journal of Geology, 104: 91-107.

Rossetti, D. F. 2010. Tectonic control on the stratigraphy framework of late pleistocene and holocene deposits in Marajó Island, State of Pará, eastern Amazonia. An. Acad. Bras.Ciênc., 82: 439-450.

Rossetti, D. F. 2006. Evolução sedimentar miocênica nos Estados do Pará e Maranhão. Geol. USP. Ser. Cient., 6:7-18.

Rossetti, D. F. 2004. Paleosurfaces from northeastern Amazonia as a key for reconstructing paleolandscapes and understanding weathering products. Sedimentary Geology, 169: 151-174.

Rossetti, D. F. 2003. Delineating shallow Neogene deformation structures in northeastern Pará State using ground penetrating radar. An. Aca. Bras. Ciênc., Rio de Janeiro, 75: 235-248.

Rossetti, D. F. 2001. Late Cenozoic sedimentary evolution in northeastern Pará, Brazil, within the context of sea level changes. Journal of South American Earth Sciences, 14: 77-89.

Rossetti, D. F. 2000a. Late sedimentary evolution in northeastern Pará state, Brazil, within the context of sea level changes. Journal of South American Earth Sciences, p. 1-13. 
Rossetti, D. F. 2000b. Influence of low amplitude/high frequency relative sea-level changes in a wave-dominated estuary (Miocene), São Luís Basin, northern Brazil. Sedimentary Geology, 133: 295-324.

Rossetti, D. F.; Bezerra, F. H. R.; Góes, A. M.; Neves, B. B. B. Sediment deformation in Miocene and post-Miocene strata, Northeastern Brazil: evidence for paleoseismicity in a passive margin. Sedimentary Geology. (no prelo).

Rossetti, D. F. \& Góes, A. M. 2008. Late quaternary drainage dynamics in northern Brazil based on the study of a large paleochannel from southwestern Marajó Island. An. Acad. Bras. Ciênc., 80: 579-593.

Rossetti, D. F. \& Góes, A. M. 2001. Imaging upper Tertiary to Quaternary deposits from northern Brazil applying Ground Penetrating Radar. Rev. Bras. Geoc., 31 (2): 195-202.

Rossetti, D. F.; Góes, A. M.; Souza, L. S. B. 2001. Estratigrafia da Sucessão Sedimentar Pós-Barreiras (Zona Bragantina, Pará) com base em Radar de Penetração no Solo. Rev. Bras. Geof., 19: 113-130.

Rossetti, D. F.; Góes, A. M.; Valeriano, M. M.; Thallês, M. 2008a. Paleodrainage in Marajó Island (northern Brazil) and its relation to Holocene relative sea-level dynamics. Holocene, 18: 923-934.

Rossetti, D. F; Góes, A. M.; Valeriano, M. M; Miranda, M. C. C. 2008b. Quaternary tectonics in a passive margin: Marajó Island, northern Brazil. Journal of Quaternary Science, 23: 121-135.

Rossetti, D. F. \& Santos Júnior, A. E. A. 2004. Facies architecture in a tectonicallyinfluenced estuarine incised valley fill of Miocene age, northern Brazil. Journal of South American Earth Sciences, 17: 267-284. 
Rossetti, D. F. \& Valeriano, M. M. 2007. Evolution of the lowest amazon basin modeled from the integration of geological and SRTM topographic data. Catena, 70 (2): 253265.

Rossetti, D. F.; Valeriano, M. M.; Thallês, M. 2007. An abandoned estuary within Marajó Island: implications for late quaternary paleogeography of northern Brazil. Estuaries and Coasts, 30: 813-826.

Rossetti, D. F. \& Toledo, P. M. 2006. Biodiversity from a historical geology perspective: a cause study from Marajó Island, lower Amazon. Geobiology, 4: 215-223.

Rossetti, D. F. \& Truckenbrodt, W. 1989. Estudo paleoambiental e estratigráfico dos Sedimentos Barreiras e Pós-Barreiras na região Bragantina, nordeste do Pará. Bol. Museu Paraense Emílio Goeldi, sér. Ciências da Terra 1, 1: 25-28.

Rozo, J. M. G.; Nogueira, A. C. R.; Carvalho, A. S. 2005. Análise multitemporal do sistema fluvial do Amazonas entre a Ilha do Careiro e a Foz do Rio Madeira. In: $12^{\mathrm{a}}$. Simp. Bras. Sensoriamento Remoto. Goiânia/GO. Anais.

Rowan, M. G.; Peel, F. J., Vendeville, B. C. 2004. Gravity driven fold belts on passive margins. In: McClay, K. R. (ed.). Thrust tectonics and hydrocarbon systems. AAPG Memoir, 82: 157-182.

Saadi, A. \& Torquato, J. R. 1992. Contribuição à Neotectônica do Estado do Ceará. Revista da Geologia, 5: 5-38.

Sabins, J. F. F. 1978. Remote sensing: principles and interpretation. San Franscisco: W. H. Freeman, 426p.

Santos, C. P. L. 2003. Análise geofísica das características hidráulicas da falha de Salvador na Região de Arembepe-Ba. Salvador (BA). CPGG/UFBA. 93p. (Dissertação de Mestrado). 
Schobbenhaus, C. \& Campos, D. A. 1984. A evolução da Plataforma Sul-Americana no Brasil e suas principais concentrações minerais. In: Schobbenhaus, C., Campos, D. A.; Derze, G. R.; Asmus, H. E. (coord.), Geologia do Brasil. Texto explicativo do Mapa Geológico do Brasil e da área oceânica adjacente incluindo depósitos minerais, escala 1:2.500.000. Brasília: DNPM, p: 9-56.

Schumm, S. A. 1981. Evolution and response of the fluvial system: Sedimentologic implications. SEPM Special Publucation, 31: 19-29.

Schumm, S. A. 1986. Alluvial river response to active tectonics. Active Tectonics. National Academy Press, Washington, D.C.: 80-95.

Secretaria Executiva de Estado de Planejamento, Orçamento e Finanças (SEPOF). 2004. Município de Salvaterra (PA). Governo do Estado do Pará. Relatório Interno.

Shtober-Zisu, N.; Greenbaum, N.; Inbar, M.; Flexer, A. 2008. Morphometric and geomorphic approaches for assessment of tectonic activity, Dead Sea Rift (Israel). Geomorphology, 102: 93-104.

Sifeddine, A.; Marint, L.; Turcq, B.; Volkmer-Ribeiro, C.; Soubiès, F.; Cordeiro, R. C.; Suguio, K. 2001. Variations of the Amazonian rainforest environment: a sedimentological record covering 30,000 years. Palaeogeography, Palaeoclimatology, Palaeoecology, 168: 221-235.

Silva, C. L. 2005. Análise da tectônica cenozóica da região de Manaus e adjacências. Rio Claro (SP). UNESP-IGCE. 306p. (Tese de Doutoramento).

Silva, F. G. \& Scherer, C. M. S. 2000. Morphological characterization of ancient eolian dunes using the ground-penetring radar, Botucatu Formation, southern Brazil. Rev. Bras. Geoc., 30: 531-534. 
Silva, R. J. P. 2008. Colapso gravitacional e estruturação da seção marinha da bacia da Foz do Amazonas no contexto de múltiplos níveis de destacamento. Niterói (RJ). UFF. 101p. (Dissertação de Mestrado).

Silva, S. R. P.; Maciel, R. R.; Severino, M. C. G. 1999. Cenozoic tectonics of Amazon Mouth Basin. Geo - Marine Letters, 18: 256-262.

Soares Jr., A. V.; Costa, J. B. S.; Hasui, Y. 2008. Evolution of the Brazilian Equatorial Atlantic margin: three extensional phases. Geociências, 27: 1-14.

Soares, P. C. \& Fiori, A. P. 1976. Lógica e sistemática na análise e interpretação de fotografias aéreas em geologia. Notícia Geomorfológica, Campinas, 16 (32).

Sousa, G. M.; Fávera, J. C. D.; Medeiros, M. A. M.; Menezes, P. T. L. 2005. Levantamento GPR em cordões litorâneos para o estudo de reservatórios análogos. Estudo de caso no Munícipio de Marataízes (ES). In: Cong. Bra. Petróleo \& Gás, 3, Salvador (BA). Anais...

Souza, L. S. B. 2005. Mapeamento de aqüíferos na Cidade de Manaus (AM) - utilizando Perfilagem Geofísica de Poço e Sondagem Elétrica Vertical. Belém (PA). CPGf-UFPA. 84p. (Dissertação de Mestrado).

Souza, L. S. B. \& Verma, O. 2005. Mapeamento de aqüíferos na Cidade de Manaus/AM (zonas norte e leste) através de Perfilagem Geofísica de Poço e Sondagem Elétrica Vertical. Rev. Geol., 18: 227-243.

Souza Filho, P. W. M. 2000. Tectonic control on the coastal zone geomorphology of the northeastern Pará State. Rev. Bras. Geoc., 30: 523-526.

Souza Filho, P. W. M. \& El Robrini, M. 2000. Coastal zone geomorphology of the Bragança area, northeast of Amazon Region, Brazil. Rev. Bras. Geoc., 30: 518-522. 
Souza Filho, P. W. M. \& Paradella, W. R. 2003. Use of synthetic aperture radar for recognition of coastal geomorphological features, land-use assessment and shoreline changes in Bragança coast, Pará, northern Brazil. An. Acad. Bras. Ciênc., 75: 341-356.

Souza Filho, P. W.; Paradella, W. R.; Souza Júnior, C.; Valeriano, D. M.; Miranda, F. P. 2006. Sensoriamento remoto e recursos naturais da Amazônia. São Paulo. Cienc. Cult., 58: $1-16$.

Sternberg, H. O. 1950. Vales tectônicos na planície amazônica. Rev. Bras. Geografia, 12: 3-26.

Summerfield, M. A. 1991. Global Geomorphology. New York, Jonh Wiley \& Sons. 537p.

Szatmari, P.; Françolin, J. B. L.; Zanotto, O.; Wolff, S. 1987. Evoluçao tectônica da margem equatorial brasileira. Rev. Bras. Geoc., 17: 180-188.

Tatumi, S. H.; Silva, L. P.; Pires, E. L.; Rossetti, D. F.; Góes, A. M.; Munita, C. S. 2008. Datação de Sedimentos Pós-Barreiras no norte do Brasil: implicações paleogeográficas. Rev. Bras. Geoc., 38: 514-524.

Teixeira Neto, J. F.; Souza Filho, A. P. da S.; Marques, J. R. F.; Camarão, A. P.; Teixeira, R. N. G. 1991. Introdução e avaliação de forrageiras na Ilha de Marajó-Pará. Belém (PA). Embrapa-CPATU. Boletim de Pesquisa, n. 122, 10p.

Telford, W. M.; Geldart, L. P.; Sheriff, R. E. 1990. Applied Geophysics. Cambrige University Press, $2^{\text {ed }}$, 770p.

Trancredi, A. C. 1972. Aplication de la prospection électrique à l'ètude hidrogéologique da Ilha do Marajó - état du Pará, Bresil. Diplome Et. Sup. Strasbourg, Multig. 25p.

Travassos, W. A. \& Barbosa Filho, C. M. 1990. Tectonismo terciário na área do Rio Tapajós, Bacia do Amazonas. Boletim de Geociências da Petrobrás, 4: 299-314 
Uchua, J. M.; Vilas Boas, G. S.; Botelho, M.; Ribeiro, L. P.; Santana, P. S. 1999. Utilização de radar de penetração no solo - GPR na identificação das camadas de fragipã e de duripã nos solos desenvolvidos sobre os sedimentos do Grupo Barreiras. In: SBG/Porto Seguro, VII Congresso da ABEQUA, Resumos.

Van Heteren, S.; Fitzgerald, D. M.; P. A.; Buynevich, I. V. 1998. Radar facies of paraglacial barrier systems: coastal New England, USA. Sedimentology, 45: 181-200.

Vaughan, C. J. 1986. Ground-pentration radar surveys used in archaeological investigations. Geophysics, 51: 595-604.

Vedel, V.; Behling, H.; Cohen, M. C. L.; Lara, R. J. 2006. Holocene mangrove dynsamics and sea-level changes in northern Brazil, inferences from the Taperebal core in northeastern Pará State. Vegetation History And Archaeobotany, 15: 115-123.

Vendeville, B. C. \& Gaullier, V. 2003. Role of pore-fluid pressure and slope angle in triggering submarine mass movements: Natural examples and pilot experimental models. In: Locat, J. \& Mienert, J. (eds.). Submarine mass movements and their consequences. First International Symposium: Netherlands, Kluwer Academic Publishers, p: 137-144.

Verma, O. P. \& Bischoff, J. H. 1989. Laboratory and field studies of the application of electromagnetic prospecting for groundwater on Marajó Island, Brazil. Geophysics, 54: 23-30.

Villegas, J. M. 1994. Geologia estrutural da Bacia de Marajó. Belém (PA). CPGG- UFPA. 119p. (Dissertação de Mestrado).

Wyatt, D. E. \& Tempes, T. J. 1996. Ground-penetrating radar detection of small-scale channels, joints and faults in the unconsolidated sediments of the Atlantic Coast Plain. Environmental Geology, 27: 219 - 225. 


\section{LISTA DE ANEXOS}

ANEXO I - Tabelas de campo das 21 SEV coletadas na porção leste da Ilha do Marajó.

\begin{tabular}{|c|c|c|c|c|c|c|c|c|c|c|c|c|}
\hline \multicolumn{13}{|c|}{ SEV 1} \\
\hline \multirow{2}{*}{$\begin{array}{c}\mathrm{AB} / 2 \\
(\mathrm{~m})\end{array}$} & \multicolumn{6}{|c|}{$\mathrm{MN}(\mathrm{m})$} & \multirow[t]{2}{*}{$\begin{array}{c}\Delta V \\
(m V)\end{array}$} & \multirow[t]{2}{*}{$\begin{array}{c}I \\
(\mathrm{~mA})\end{array}$} & \multirow[t]{2}{*}{$\begin{array}{c}\rho_{\mathrm{a} 1} \\
(\Omega \mathrm{m})\end{array}$} & \multirow[t]{2}{*}{$\begin{array}{c}\Delta V \\
(m V)\end{array}$} & \multirow[t]{2}{*}{$\underset{(\mathrm{mA})}{\mathrm{I}}$} & \multirow[t]{2}{*}{$\begin{array}{c}\rho_{\mathrm{a} 2} \\
(\Omega \mathrm{m})\end{array}$} \\
\hline & 0,5 & 2 & 5 & 20 & 50 & 100 & & & & & & \\
\hline 1 & 5,89 & & & & & & 126,1 & 1,6 & 462 & & & \\
\hline 1,3 & 10,22 & & & & & & 186 & 4,4 & 432 & & & \\
\hline 1,8 & 19,96 & & & & & & 165,3 & 6,7 & 270 & & & \\
\hline 2,4 & 35,8 & & & & & & 227 & 14,1 & 576 & & & \\
\hline 3,2 & 63,95 & & & & & & 172 & 16,6 & 662 & & & \\
\hline 4,2 & 110,4 & & & & & & 72,4 & 11,5 & 695 & & & \\
\hline 5,5 & 189,7 & 45,95 & & & & & 45,7 & 11,6 & 747 & 47,5 & 16 & 136 \\
\hline 7,5 & 353 & 86,79 & & & & & 57,5 & 28,9 & 702 & 218 & 28,9 & 655 \\
\hline 10 & 627,9 & 155,5 & & & & & 44,5 & 41,7 & 670 & 161 & 41 & 611 \\
\hline 13 & 1061,4 & 263,9 & & & & & 16,2 & 31,4 & 548 & 63,8 & 30,8 & 547 \\
\hline 18 & 2035,4 & 507,4 & & & & & 11,7 & 56,8 & 419 & 43,8 & 56,6 & 393 \\
\hline 24 & 3618,7 & 903,2 & & & & & 4,5 & 38,2 & 426 & 16,4 & 37,7 & 393 \\
\hline 32 & & 1606,9 & 639,5 & & & & 14,6 & 61,1 & 384 & 37 & 60,8 & 390 \\
\hline 42 & & 2769,3 & 1104,4 & & & & 5,9 & 40,9 & 399 & 14,7 & 40,2 & 404 \\
\hline 55 & & 4750,1 & 1896,7 & & & & 3,1 & 37,8 & 390 & 7,4 & 37 & 379 \\
\hline 75 & & & 3530,4 & 867,9 & & & 3,4 & 42,2 & 284 & 16,5 & 42,1 & 340 \\
\hline 100 & & & 6279,3 & 1555,1 & & & 1,8 & 57,6 & 196 & 8,9 & 57,3 & 242 \\
\hline 130 & & & 10615 & 2638,9 & & & 2,5 & 195 & 136 & 10,9 & 198 & 145 \\
\hline 180 & & & & 5073,7 & 1996,5 & & 4,3 & 281 & 78 & 9,8 & 286 & 68 \\
\hline 240 & & & & 9032,1 & 3579,8 & & 1,9 & 343 & 50 & 4,5 & 340 & 43 \\
\hline 320 & & & & & 6394,7 & 3138,4 & 1,6 & 139,9 & 73 & 1,4 & 139,6 & 31 \\
\hline
\end{tabular}

\begin{tabular}{|c|c|c|c|c|c|c|c|c|c|c|}
\hline \multicolumn{11}{|c|}{ SEV 2} \\
\hline \multirow{2}{*}{$\begin{array}{c}\mathrm{AB} / 2 \\
(\mathrm{~m})\end{array}$} & \multicolumn{4}{|c|}{$\mathrm{MN}(\mathrm{m})$} & \multirow[t]{2}{*}{$\underset{(m V)}{\Delta V}$} & \multirow[t]{2}{*}{$\begin{array}{c}I \\
(\mathrm{~mA})\end{array}$} & \multirow[t]{2}{*}{$\begin{array}{c}\rho_{\mathrm{a} 1} \\
(\Omega \mathrm{m})\end{array}$} & \multirow[t]{2}{*}{$\begin{array}{c}\Delta V \\
(m V)\end{array}$} & \multirow[t]{2}{*}{$\begin{array}{c}I \\
(m A)\end{array}$} & \multirow[t]{2}{*}{$\begin{array}{c}\rho_{\mathrm{a} 2} \\
(\Omega \mathrm{m})\end{array}$} \\
\hline & 0,5 & 2 & 5 & 20 & & & & & & \\
\hline 1 & 5,89 & & & & 559 & 1,3 & 2533 & & & \\
\hline 1,3 & 10,22 & & & & 248 & 1,1 & 2304 & & & \\
\hline 1,8 & 19,96 & & & & 90,8 & 1 & 1812 & & & \\
\hline 2,4 & 35,8 & & & & 65,2 & 1,6 & 1459 & & & \\
\hline 3,2 & 63,95 & & & & 100,5 & 4,8 & 1339 & & & \\
\hline 4,2 & 110,4 & & & & 76 & 7,6 & 1104 & & & \\
\hline 5,5 & 189,7 & 45,95 & & & 40,7 & 6,6 & 1170 & 166,4 & 6,4 & 1195 \\
\hline 7,5 & 353 & 86,79 & & & 34 & 9,1 & 1319 & 140,8 & 9,1 & 1343 \\
\hline 10 & 627,9 & 155,5 & & & 23,7 & 10,7 & 1391 & 96,7 & 10,6 & 1419 \\
\hline 13 & 1061,4 & 263,9 & & & 39,7 & 27,6 & 1527 & 161 & 27,6 & 1539 \\
\hline 18 & 2035,4 & 507,4 & & & 9 & 14,1 & 1299 & 35,2 & 14 & 1276 \\
\hline 24 & 3618,7 & 903,2 & & & 3 & 12,2 & 890 & 12 & 12,2 & 888 \\
\hline 32 & & 1606,9 & 639,5 & & 1,2 & 5,9 & 327 & 3,6 & 6 & 384 \\
\hline 42 & & 2769,3 & 1104,4 & & 1,8 & 23,7 & 210 & 5,5 & 23,7 & 256 \\
\hline 55 & & 4750,1 & 1896,7 & & 1,8 & 67,1 & 127 & 5,3 & 67,3 & 149 \\
\hline 75 & & & 3530,4 & 867,9 & 1,3 & 45,5 & 101 & 4,2 & 45,3 & 80 \\
\hline 100 & & & 6279,3 & 1555,1 & 1,2 & 101,4 & 74 & 4,2 & 101,2 & 65 \\
\hline
\end{tabular}




\begin{tabular}{|c|c|c|c|c|c|c|c|c|c|c|c|}
\hline \multicolumn{12}{|c|}{ SEV 3} \\
\hline \multirow{2}{*}{$\begin{array}{c}A B / 2 \\
(m)\end{array}$} & \multicolumn{5}{|c|}{$\operatorname{MN}(\mathrm{m})$} & \multirow[t]{2}{*}{$\begin{array}{c}\Delta V \\
(\mathrm{mV})\end{array}$} & \multirow[t]{2}{*}{$\underset{(\mathrm{mA})}{\mathrm{I}}$} & \multirow[t]{2}{*}{$\begin{array}{c}\rho_{\mathrm{a} 1} \\
(\Omega \mathrm{m})\end{array}$} & \multirow[t]{2}{*}{$\begin{array}{c}\Delta V \\
(m V)\end{array}$} & \multirow[t]{2}{*}{$\underset{(\mathrm{mA})}{I}$} & \multirow[t]{2}{*}{$\begin{array}{c}\rho_{\mathrm{a} 2} \\
(\Omega \mathrm{m})\end{array}$} \\
\hline & 0,5 & 2 & 5 & 20 & 50 & & & & & & \\
\hline 1 & 5,89 & & & & & 518 & 2,4 & 1271 & & & \\
\hline 1,3 & 10,22 & & & & & 711 & 6,1 & 1191 & & & \\
\hline 1,8 & 19,96 & & & & & 310 & 4,1 & 1509 & & & \\
\hline 2,4 & 35,8 & & & & & 106,3 & 2,6 & 1464 & & & \\
\hline 3,2 & 65,95 & & & & & 120,2 & 5 & 1537 & & & \\
\hline 4,2 & 110,4 & & & & & 74 & 5,4 & 1513 & & & \\
\hline 5,5 & 189,7 & 45,95 & & & & 35 & 4,2 & 1581 & 145,3 & 4,3 & 1553 \\
\hline 7,5 & 353 & 86,79 & & & & 20,5 & 4,7 & 1540 & 74,4 & 4,9 & 1318 \\
\hline 10 & 627,9 & 155,5 & & & & 11,7 & 5,6 & 1312 & 38,3 & 5,5 & 1083 \\
\hline 13 & 1061,4 & 263,9 & & & & 14,4 & 15,1 & 1012 & 54 & 15,4 & 925 \\
\hline 18 & 2035,4 & 507,4 & & & & 5,8 & 18,3 & 645 & 30,8 & 18,7 & 836 \\
\hline 24 & & 903,2 & 358 & & & 15,2 & 23,8 & 577 & 52,3 & 23,9 & 783 \\
\hline 32 & & 1606,9 & 639,5 & & & 13,9 & 45 & 496 & 46,5 & 43,6 & 682 \\
\hline 42 & & 2769,3 & 1104,4 & & & 6,3 & 34,4 & 507 & 17 & 34,2 & 549 \\
\hline 55 & & 4750,1 & 1896,7 & & & 5,4 & 41,4 & 620 & 10,2 & 41,3 & 468 \\
\hline 75 & & & 3530,4 & 867,9 & & 7,2 & 45,4 & 560 & 10,1 & 45,5 & 193 \\
\hline 100 & & & 6279,3 & 1555,1 & & 6,7 & 21,5 & 1957 & 11,1 & 21,7 & 795 \\
\hline 130 & & & & 2638,9 & 1022,6 & 8,7 & 52,1 & 441 & 16,4 & 51,3 & 327 \\
\hline 180 & & & & 5073,7 & 1996,5 & 6,4 & 102,4 & 317 & 13 & 102,7 & 253 \\
\hline 240 & & & & 9032,1 & 3579,8 & 9,2 & 197 & 422 & 4,7 & 197 & 85 \\
\hline
\end{tabular}

\begin{tabular}{|c|c|c|c|c|c|c|c|c|c|c|}
\hline \multicolumn{11}{|c|}{ SEV 4} \\
\hline \multirow{2}{*}{$\begin{array}{c}\mathrm{AB} / 2 \\
(\mathrm{~m})\end{array}$} & \multicolumn{4}{|c|}{$M N(m)$} & \multirow[t]{2}{*}{$\begin{array}{c}\Delta V \\
(m V)\end{array}$} & \multirow[t]{2}{*}{$\begin{array}{c}I \\
(\mathrm{~mA})\end{array}$} & \multirow[t]{2}{*}{$\begin{array}{c}\rho_{\mathrm{a} 1} \\
(\Omega \mathrm{m})\end{array}$} & \multirow[t]{2}{*}{$\begin{array}{c}\Delta V \\
(m V)\end{array}$} & \multirow[t]{2}{*}{$\begin{array}{c}I \\
(\mathrm{~mA})\end{array}$} & \multirow[t]{2}{*}{$\begin{array}{c}\rho_{\mathrm{a} 2} \\
(\Omega \mathrm{m})\end{array}$} \\
\hline & 0,5 & 2 & 5 & 20 & & & & & & \\
\hline 1, & 5,89 & & & & 557 & 2 & 1640 & & & \\
\hline 1,3 & 10,22 & & & & 314 & 1,8 & 1783 & & & \\
\hline 1,8 & 19,96 & & & & 204 & 1,8 & 2262 & & & \\
\hline 2,4 & 35,8 & & & & 89,7 & 1,4 & 2294 & & & \\
\hline 3,2 & 63,95 & & & & 59 & 1,6 & 2358 & & & \\
\hline 4,2 & 110,4 & & & & 29,3 & 1,4 & 2311 & & & \\
\hline 5,5 & 189,7 & 45,95 & & & 21,6 & 1,8 & 2276 & 100 & 1,8 & 2553 \\
\hline 7,5 & 353 & 86,79 & & & 48,1 & 7,3 & 2326 & 220 & 7,3 & 2616 \\
\hline 10 & 627,9 & 155,5 & & & 20,8 & 6,3 & 2073 & 97,7 & 6,3 & 2411 \\
\hline 13 & 1061,4 & 263,9 & & & 7,7 & 4,6 & 1777 & 35,3 & 4,7 & 1982 \\
\hline 18 & 2035,4 & 507,4 & & & 6,2 & 7,9 & 1597 & 28,9 & 8 & 1833 \\
\hline 24 & 3618,7 & 903,2 & & & 3,1 & 12,5 & 897 & 13,8 & 12,6 & 989 \\
\hline 32 & & 1606,9 & 639,5 & & 4,6 & 9,9 & 747 & 11,3 & 9,9 & 730 \\
\hline 42 & & 2769,3 & 1104,4 & & 1,6 & 10,2 & 434 & 4,4 & 10,3 & 472 \\
\hline 55 & & 4750,1 & 1896,7 & & 1,9 & 32,4 & 279 & 5,5 & 32,3 & 323 \\
\hline 75 & & & 3530,4 & 867,9 & 2,6 & 30 & 306 & 11,8 & 30 & 341 \\
\hline 100 & & & 6279,3 & 1555,1 & 2 & 55,6 & 226 & 7,2 & 55,6 & 201 \\
\hline 130 & & & 10615 & 2638,9 & 1,5 & 56,6 & 281 & 4,2 & 56,4 & 197 \\
\hline
\end{tabular}




\begin{tabular}{|c|c|c|c|c|c|c|c|c|c|c|c|}
\hline \multicolumn{12}{|c|}{ SEV 5} \\
\hline \multirow{2}{*}{$\begin{array}{c}\mathrm{AB} / 2 \\
(\mathrm{~m})\end{array}$} & \multicolumn{5}{|c|}{$M N(m)$} & \multirow[t]{2}{*}{$\underset{(m V)}{\Delta V}$} & \multirow[t]{2}{*}{$\underset{(\mathrm{mA})}{I}$} & \multirow[t]{2}{*}{$\begin{array}{c}\rho_{\mathrm{a} 1} \\
(\Omega \mathrm{m})\end{array}$} & \multirow[t]{2}{*}{$\begin{array}{c}\Delta V \\
(m V)\end{array}$} & \multirow[t]{2}{*}{$\begin{array}{c}I \\
(\mathrm{~mA})\end{array}$} & \multirow[t]{2}{*}{$\begin{array}{c}\rho_{\mathrm{a} 2} \\
(\Omega \mathrm{m})\end{array}$} \\
\hline & 0,5 & 2 & 5 & 20 & 50 & & & & & & \\
\hline 1 & 5,89 & & & & & 706 & 1,9 & 2189 & & & \\
\hline 1,3 & 10,22 & & & & & 718 & 2,7 & 2718 & & & \\
\hline 1,8 & 19,96 & & & & & 707 & 2 & 7056 & & & \\
\hline 2,4 & 35,8 & & & & & 365 & 1,8 & 7259 & & & \\
\hline 3,2 & 63,95 & & & & & 187 & 2 & 5979 & & & \\
\hline 4,2 & 110,4 & & & & & 84,2 & 1,9 & 4892 & & & \\
\hline 5,5 & 189,7 & 45,95 & & & & 62,7 & 2,9 & 4101 & 257 & 2,9 & 4072 \\
\hline 7,5 & 353 & 86,79 & & & & 24,9 & 2,7 & 3255 & 97 & 2,6 & 3238 \\
\hline 10 & 627,9 & 155,5 & & & & 9,8 & 2,1 & 2930 & 36,5 & 2,1 & 2703 \\
\hline 13 & 1061,4 & 263,9 & & & & 5,6 & 2,1 & 2830 & 21,1 & 2,1 & 2652 \\
\hline 18 & 2035,4 & 507,4 & & & & 23,2 & 16,3 & 2897 & 89,9 & 16,5 & 2765 \\
\hline 24 & 3618,7 & 903,2 & & & & 9,4 & 13,1 & 2597 & 36,1 & 13,1 & 2489 \\
\hline 32 & & 1606,9 & 639,5 & & & 3,4 & 2,8 & 1951 & 8,1 & 2,7 & 1919 \\
\hline 42 & & 2769,3 & 1104,4 & & & 2,2 & 4,4 & 1385 & 5,2 & 4,4 & 1305 \\
\hline 55 & & & 1896,7 & 459,5 & & 1,2 & 3,2 & 711 & 5,2 & 3,1 & 771 \\
\hline 75 & & & 3530,4 & 867,9 & & 1,3 & 8 & 574 & 5,6 & 8 & 608 \\
\hline 100 & & & 6279,3 & 1555,1 & & 1,6 & 24,4 & 412 & 7,4 & 24,4 & 472 \\
\hline 130 & & & 10615 & 2638,9 & & 1,1 & 26,8 & 436 & 4,9 & 26,7 & 484 \\
\hline 180 & & & & 5073,7 & 1996,5 & 1,6 & 60,7 & 134 & 5,7 & 60,2 & 189 \\
\hline 240 & & & & 9032,1 & 3579,8 & 1,6 & 58,2 & 248 & 3,4 & 57,8 & 211 \\
\hline 320 & & & & 16069 & 6394,7 & 3,2 & 58,8 & 875 & 1,8 & 58,4 & 197 \\
\hline
\end{tabular}

\begin{tabular}{|c|c|c|c|c|c|c|c|c|c|c|c|}
\hline \multicolumn{12}{|c|}{ SEV 6} \\
\hline \multirow{2}{*}{$\begin{array}{c}A B / 2 \\
(\mathrm{~m})\end{array}$} & \multicolumn{5}{|c|}{$\mathrm{MN}(\mathrm{m})$} & \multirow[t]{2}{*}{$\begin{array}{c}\Delta V \\
(m V)\end{array}$} & \multirow[t]{2}{*}{$\begin{array}{c}I \\
(\mathrm{~mA})\end{array}$} & \multirow[t]{2}{*}{$\begin{array}{c}\rho_{\mathrm{a} 1} \\
(\Omega \mathrm{m})\end{array}$} & \multirow[t]{2}{*}{$\begin{array}{c}\Delta V \\
(m V)\end{array}$} & \multirow[t]{2}{*}{$\begin{array}{c}I \\
(m A)\end{array}$} & \multirow[t]{2}{*}{$\begin{array}{c}\rho_{\mathrm{a} 2} \\
(\Omega \mathrm{m})\end{array}$} \\
\hline & 0,5 & 2 & 5 & 20 & 50 & & & & & & \\
\hline 1 & 5,89 & & & & & 479 & 0,6 & 4702 & & & \\
\hline 1,3 & 10,22 & & & & & 194 & 0,5 & 3965 & & & \\
\hline 1,8 & 19,96 & & & & & 120 & 0,5 & 4790 & & & \\
\hline 2,4 & 35,8 & & & & & 540 & 3,1 & 6236 & & & \\
\hline 3,2 & 63,95 & & & & & 308 & 3,4 & 5793 & & & \\
\hline 4,2 & 110,4 & & & & & 248 & 5,3 & 5166 & & & \\
\hline 5,5 & 189,7 & 45,95 & & & & 118,1 & 5,1 & 4393 & 484 & 5,2 & 4277 \\
\hline 7,5 & 353 & 86,79 & & & & 54,1 & 5,3 & 3603 & 214 & 5,4 & 3439 \\
\hline 10 & 627,9 & 155,5 & & & & 17,5 & 3,9 & 2818 & 64,8 & 3,9 & 2584 \\
\hline 13 & 1061,4 & 263,9 & & & & 8,7 & 4 & 2309 & 32,5 & 4 & 2144 \\
\hline 18 & 2035,4 & 507,4 & & & & 5,3 & 4,9 & 2202 & 18,3 & 4,9 & 1895 \\
\hline 24 & 3618,7 & 903,2 & & & & 2,2 & 2,8 & 2843 & 5,2 & 2,9 & 1620 \\
\hline 32 & & 1606,9 & 639,5 & & & 4,1 & 4,6 & 1432 & 9,3 & 4,6 & 1293 \\
\hline 42 & & 2769,3 & 1104,4 & & & 2,3 & 4,5 & 1415 & 4,8 & 4,5 & 1178 \\
\hline 55 & & 4750,1 & 1896,7 & & & 1,6 & 4,2 & 1810 & 2,7 & 4,4 & 1164 \\
\hline 75 & & 8834,2 & 3530,4 & & & 1,5 & 10,2 & 1299 & 2,8 & 10,2 & 969 \\
\hline 100 & & & 6279,3 & 1555,1 & & 1,3 & 10,7 & 763 & 5,2 & 10,6 & 763 \\
\hline 130 & & & 10615 & 2638,9 & & 2,7 & 25,7 & 1115 & 7,7 & 25,8 & 788 \\
\hline 180 & & & 20354 & 5073,7 & & 1,4 & 36,9 & 772 & 4,6 & 36,8 & 634 \\
\hline 240 & & & & 9032,1 & 3579,8 & 2,7 & 12,6 & 1935 & 6,2 & 12,4 & 1790 \\
\hline 320 & & & & 16069 & 6394,7 & 2,6 & 28,5 & 1466 & 4,3 & 28,5 & 965 \\
\hline
\end{tabular}




\begin{tabular}{|c|c|c|c|c|c|c|c|c|c|c|c|c|}
\hline \multicolumn{13}{|c|}{ SEV 7} \\
\hline \multirow{2}{*}{$\begin{array}{c}\mathrm{AB} / 2 \\
(\mathrm{~m})\end{array}$} & \multicolumn{6}{|c|}{$\mathrm{MN}(\mathrm{m})$} & \multirow[t]{2}{*}{$\underset{(\mathrm{mV})}{\Delta \mathrm{V}}$} & \multirow[t]{2}{*}{$\begin{array}{c}I \\
(\mathrm{~mA})\end{array}$} & \multirow[t]{2}{*}{$\begin{array}{c}\rho_{\mathrm{a} 1} \\
(\Omega \mathrm{m})\end{array}$} & \multirow[t]{2}{*}{$\begin{array}{c}\Delta V \\
(m V)\end{array}$} & \multirow[t]{2}{*}{$\underset{(\mathrm{mA})}{\mathrm{I}}$} & \multirow[t]{2}{*}{$\begin{array}{c}\rho_{\mathrm{a} 2} \\
(\Omega \mathrm{m})\end{array}$} \\
\hline & 0,5 & 2 & 5 & 20 & 50 & 100 & & & & & & \\
\hline 1 & 5,89 & & & & & & 707 & 1,7 & 2450 & & & \\
\hline 1,3 & 10,22 & & & & & & 712 & 2,3 & 3164 & & & \\
\hline 1,8 & 19,96 & & & & & & 298 & 1 & 5948 & & & \\
\hline 2,4 & 35,8 & & & & & & 175,1 & 1,3 & 4822 & & & \\
\hline 3,2 & 63,95 & & & & & & 85,3 & 1,5 & 3637 & & & \\
\hline 4,2 & 110,4 & & & & & & 36,8 & 1,5 & 2708 & & & \\
\hline 5,5 & 189,7 & 45,95 & & & & & 18,1 & 1,5 & 2289 & 72,5 & 1,5 & 2221 \\
\hline 7,5 & 353 & 86,79 & & & & & 9,5 & 1,6 & 2096 & 37,2 & 1,6 & 2018 \\
\hline 10 & 627,9 & 155,5 & & & & & 5,8 & 1,6 & 2276 & 22,7 & 1,5 & 2353 \\
\hline 13 & 1061,4 & 263,9 & & & & & 2,2 & 1 & 2335 & 7,9 & 1 & 2085 \\
\hline 18 & 2035,4 & 507,4 & & & & & 1,4 & 1,2 & 2375 & 4,8 & 1,2 & 2030 \\
\hline 24 & 3618,7 & 903,2 & & & & & 1,3 & 1,8 & 2614 & 4,4 & 1,7 & 2338 \\
\hline 32 & & 1606,9 & 639,5 & & & & 1,6 & 1,4 & 1836 & 3,4 & 1,4 & 1553 \\
\hline 42 & & 2769,3 & 1104,4 & & & & 1,8 & 2,6 & 1917 & 3,1 & 2,6 & 1317 \\
\hline 55 & & & 1896,7 & 459,5 & & & 1,8 & 3,6 & 948 & 5,8 & 3,8 & 701 \\
\hline 75 & & & 3530,4 & 867,9 & & & 1,5 & 11,6 & 457 & 5 & 11,6 & 374 \\
\hline 100 & & & 6279,3 & 1555,1 & & & 1,1 & 10,3 & 671 & 2,1 & 9,8 & 333 \\
\hline 130 & & & & 2638,9 & 1022,6 & & 1,8 & 8,2 & 579 & 1,7 & 9,6 & 181 \\
\hline 180 & & & & 5073,7 & 1996,5 & & 1,8 & 34,8 & 262 & 1,6 & 34,4 & 93 \\
\hline 240 & & & & & 3579,8 & 1731 & 5,3 & 38 & 499 & 2,2 & 38 & 100 \\
\hline
\end{tabular}

\begin{tabular}{|c|c|c|c|c|c|c|c|c|c|c|c|c|}
\hline \multicolumn{13}{|c|}{ SEV 8} \\
\hline \multirow{2}{*}{$\begin{array}{c}\mathrm{AB} / 2 \\
(\mathrm{~m})\end{array}$} & \multicolumn{6}{|c|}{$\mathrm{MN}(\mathrm{m})$} & \multirow[t]{2}{*}{$\begin{array}{c}\Delta V \\
(m V)\end{array}$} & \multirow[t]{2}{*}{$\begin{array}{c}I \\
(m A)\end{array}$} & \multirow[t]{2}{*}{$\begin{array}{c}\rho_{\mathrm{a} 1} \\
(\Omega \mathrm{m})\end{array}$} & \multirow[t]{2}{*}{$\underset{(m V)}{\Delta V}$} & \multirow[t]{2}{*}{$\begin{array}{c}I \\
(m A)\end{array}$} & \multirow[t]{2}{*}{$\begin{array}{c}\rho_{\mathrm{a} 2} \\
(\Omega \mathrm{m})\end{array}$} \\
\hline & 0,5 & 2 & 5 & 20 & 50 & 100 & & & & & & \\
\hline 1 & 5,89 & & & & & & 712 & 3,7 & 1133 & & & \\
\hline 1,3 & 10,22 & & & & & & 418 & 4 & 1068 & & & \\
\hline 1,8 & 19,96 & & & & & & 160 & 3,1 & 1030 & & & \\
\hline 2,4 & 35,8 & & & & & & 122,2 & 4 & 1094 & & & \\
\hline 3,2 & 63,95 & & & & & & 243 & 12,7 & 1224 & & & \\
\hline 4,2 & 110,4 & & & & & & 224 & 18,2 & 1359 & & & \\
\hline 5,5 & 189,7 & 45,95 & & & & & 113,4 & 14,9 & 1444 & 445 & 14,8 & 1382 \\
\hline 7,5 & 353 & 86,79 & & & & & 33,9 & 7,8 & 1534 & 131,9 & 7,8 & 1468 \\
\hline 10 & 627,9 & 155,5 & & & & & 39,4 & 14,9 & 1660 & 152,5 & 14,7 & 1613 \\
\hline 13 & 1061,4 & 263,9 & & & & & 25,2 & 15,9 & 1682 & 97,8 & 16 & 1613 \\
\hline 18 & 2035,4 & 507,4 & & & & & 16,6 & 20,9 & 1617 & 64,3 & 20,9 & 1561 \\
\hline 24 & 3618,7 & 903,2 & & & & & 4,9 & 12,6 & 1407 & 18,9 & 12,6 & 1355 \\
\hline 32 & & 1606,9 & 639,5 & & & & 8,5 & 12,8 & 1067 & 21,2 & 12,8 & 1059 \\
\hline 42 & & 2769,3 & 1104,4 & & & & 4,5 & 18,1 & 689 & 11,2 & 18 & 687 \\
\hline 55 & & 4750,1 & 1896,7 & & & & 1,6 & 20,8 & 365 & 4,1 & 20,8 & 374 \\
\hline 75 & & & 3530,4 & 867,9 & & & 1,3 & 33,2 & 138 & 5,7 & 33 & 150 \\
\hline 100 & & & 6279,3 & 1555,1 & & & 1,4 & 128,4 & 68 & 5,7 & 128,3 & 69 \\
\hline 130 & & & & 2638,9 & 1022,6 & & 1,8 & 108,2 & 44 & 6,1 & 107,9 & 58 \\
\hline 180 & & & & 5073,7 & 1996,5 & & 1,2 & 173,3 & 35 & 5,4 & 173,3 & 62 \\
\hline 240 & & & & & 3579,8 & 1731 & 2,1 & 133 & 57 & 3,3 & 132,6 & 43 \\
\hline
\end{tabular}




\begin{tabular}{|c|c|c|c|c|c|c|c|c|c|c|c|}
\hline \multicolumn{12}{|c|}{ SEV 9} \\
\hline \multirow{2}{*}{$\begin{array}{c}\mathrm{AB} / 2 \\
(\mathrm{~m})\end{array}$} & \multicolumn{5}{|c|}{$\mathrm{MN}(\mathrm{m})$} & \multirow[t]{2}{*}{$\begin{array}{c}\Delta V \\
(\mathrm{mV})\end{array}$} & \multirow[t]{2}{*}{$\underset{(\mathrm{mA})}{\mathrm{I}}$} & \multirow[t]{2}{*}{$\begin{array}{c}\rho_{\mathrm{a} 1} \\
(\Omega \mathrm{m})\end{array}$} & \multirow[t]{2}{*}{$\begin{array}{c}\Delta V \\
(m V)\end{array}$} & \multirow[t]{2}{*}{$\begin{array}{c}I \\
(\mathrm{~mA})\end{array}$} & \multirow[t]{2}{*}{$\begin{array}{c}\rho_{\mathrm{a} 2} \\
(\Omega \mathrm{m})\end{array}$} \\
\hline & 0,5 & 2 & 5 & 20 & 50 & & & & & & \\
\hline 1 & 5,89 & & & & & 710 & 0,3 & 13940 & & & \\
\hline 1,3 & 10,22 & & & & & 434 & 0,3 & 14785 & & & \\
\hline 1,8 & 19,96 & & & & & 152 & 1,9 & 1597 & & & \\
\hline 2,4 & 35,8 & & & & & 299 & 1,5 & 7136 & & & \\
\hline 3,2 & 63,95 & & & & & 147,2 & 1,9 & 4954 & & & \\
\hline 4,2 & 110,4 & & & & & 53,1 & 1,7 & 3448 & & & \\
\hline 5,5 & 189,7 & 45,95 & & & & 30,9 & 2,3 & 2549 & 92,4 & 2,4 & 1769 \\
\hline 7,5 & 353 & 86,79 & & & & 14,5 & 2,7 & 1896 & 42,2 & 2,7 & 1356 \\
\hline 10 & 627,9 & 155,5 & & & & 7,2 & 3 & 1507 & 19,4 & 3 & 1006 \\
\hline 13 & 1061,4 & 263,9 & & & & 2,4 & 2,4 & 1061 & 6,6 & 2,3 & 757 \\
\hline 18 & 2035,4 & 507,4 & & & & 1,6 & 3,5 & 930 & 4,5 & 3,6 & 634 \\
\hline 24 & 3618,7 & 903,2 & & & & 1,3 & 5,9 & 797 & 3,7 & 6 & 557 \\
\hline 32 & & 1606,9 & 639,5 & & & 1,9 & 8 & 382 & 4,3 & 8 & 344 \\
\hline 42 & & 2769,3 & 1104,4 & & & 1,1 & 8,7 & 350 & 2,1 & 8,7 & 267 \\
\hline 55 & & & 1896,7 & 459,5 & & 1 & 12,8 & 148 & 6,3 & 12,8 & 226 \\
\hline 75 & & & 3530,4 & 867,9 & & 1,2 & 35,8 & 118 & 3,5 & 35,8 & 85 \\
\hline 100 & & & 6279,3 & 1555,1 & & 1,2 & 46,8 & 161 & 1,6 & 46,7 & 53 \\
\hline 130 & & & & 2638,9 & 1022,6 & 2,6 & 61,7 & 111 & 2,3 & 61,4 & 38 \\
\hline 180 & & & & 5073,7 & 1996,5 & 1,7 & 48,4 & 178 & 1,2 & 48,2 & 50 \\
\hline 240 & & & & 9032,1 & 3579,8 & 2,2 & 41,2 & 482 & 1,2 & 40,9 & 105 \\
\hline
\end{tabular}

\begin{tabular}{|c|c|c|c|c|c|c|c|c|c|c|}
\hline \multicolumn{11}{|c|}{ SEV 10} \\
\hline \multirow{2}{*}{$\begin{array}{c}A B / 2 \\
(m)\end{array}$} & \multicolumn{4}{|c|}{$\mathrm{MN}(\mathrm{m})$} & \multirow[t]{2}{*}{$\begin{array}{c}\Delta V \\
(m V)\end{array}$} & \multirow[t]{2}{*}{$\begin{array}{c}I \\
(\mathrm{~mA})\end{array}$} & \multirow[t]{2}{*}{$\begin{array}{c}\rho_{\mathrm{a} 1} \\
(\Omega \mathrm{m})\end{array}$} & \multirow[t]{2}{*}{$\underset{(\mathrm{mV})}{\Delta \mathrm{V}}$} & \multirow[t]{2}{*}{$\underset{(m A)}{I}$} & \multirow[t]{2}{*}{$\begin{array}{c}\rho_{\mathrm{a} 2} \\
(\Omega \mathrm{m})\end{array}$} \\
\hline & 0,5 & 2 & 5 & 20 & & & & & & \\
\hline 1 & 5,89 & & & & 710 & 5,1 & 820 & & & \\
\hline 1,3 & 10,22 & & & & 500 & 4,2 & 1217 & & & \\
\hline 1,8 & 19,96 & & & & 184,4 & 4,2 & 876 & & & \\
\hline 2,4 & 35,8 & & & & 109,3 & 5,1 & 767 & & & \\
\hline 3,2 & 63,95 & & & & 42,1 & 3,8 & 708 & & & \\
\hline 4,2 & 110,4 & & & & 20,9 & 3,5 & 659 & & & \\
\hline 5,5 & 189,7 & 45,95 & & & 20,3 & 6 & 642 & 40,4 & 6 & 309 \\
\hline 7,5 & 353 & 86,79 & & & 7,2 & 4,7 & 541 & 31 & 4,7 & 572 \\
\hline 10 & 627,9 & 155,5 & & & 3,2 & 5,1 & 394 & 13,9 & 5,2 & 416 \\
\hline 13 & 1061,4 & 263,9 & & & 1,6 & 6 & 283 & 5,8 & 6 & 255 \\
\hline 18 & & 507,4 & 199,6 & & 5,2 & 22,4 & 118 & 13,7 & 22,4 & 122 \\
\hline 24 & & 903,2 & 358 & & 2,6 & 19,5 & 120 & 2,7 & 19,5 & 50 \\
\hline 32 & & 1606,9 & 639,5 & & 1,6 & 102,4 & 25 & 4 & 102,5 & 25 \\
\hline 42 & & 2769,3 & 1104,4 & & 1,3 & 75,5 & 48 & 1,2 & 75,4 & 18 \\
\hline 55 & & & 1896,7 & 459,5 & 1,7 & 174,6 & 18 & 3,9 & 174,6 & 10 \\
\hline 75 & & & 3530,4 & 867,9 & 1,1 & 142,1 & 27 & 2,4 & 142,5 & 15 \\
\hline
\end{tabular}




\begin{tabular}{|c|c|c|c|c|c|c|c|c|c|c|}
\hline \multicolumn{11}{|c|}{ SEV 11} \\
\hline \multirow{2}{*}{$\begin{array}{c}A B / 2 \\
(m)\end{array}$} & \multicolumn{4}{|c|}{$\mathrm{MN}(\mathrm{m})$} & \multirow[t]{2}{*}{$\underset{(m V)}{\Delta V}$} & \multirow[t]{2}{*}{$\underset{(m A)}{I}$} & \multirow[t]{2}{*}{$\begin{array}{c}\rho_{\mathrm{a} 1} \\
(\Omega \mathrm{m})\end{array}$} & \multirow[t]{2}{*}{$\begin{array}{c}\Delta V \\
(m V)\end{array}$} & \multirow[t]{2}{*}{$\underset{(\mathrm{mA})}{\mathrm{I}}$} & \multirow[t]{2}{*}{$\begin{array}{c}\rho_{\mathrm{a} 2} \\
(\Omega \mathrm{m})\end{array}$} \\
\hline & 0,5 & 2 & 5 & 20 & & & & & & \\
\hline 1 & 5,89 & & & & 708 & 4,2 & 993 & & & \\
\hline 1,3 & 10,22 & & & & 707 & 4 & 1806 & & & \\
\hline 1,8 & 19,96 & & & & 429 & 3,1 & 2762 & & & \\
\hline 2,4 & 35,8 & & & & 175,3 & 3,2 & 1961 & & & \\
\hline 3,2 & 63,95 & & & & 81,3 & 3,4 & 1529 & & & \\
\hline 4,2 & 110,4 & & & & 38,5 & 3,2 & 1328 & & & \\
\hline 5,5 & 189,7 & 45,95 & & & 19,8 & 3,4 & 1105 & 115,5 & 4,5 & 1179 \\
\hline 7,5 & 353 & 86,79 & & & 12,6 & 5,2 & 855 & 52,8 & 5,2 & 881 \\
\hline 10 & 627,9 & 155,5 & & & 4 & 4,4 & 571 & 1,6 & 4,3 & 58 \\
\hline 13 & 1061,4 & 263,9 & & & 2,8 & 5,4 & 550 & 7,7 & 6,4 & 318 \\
\hline 18 & & 507,4 & 199,6 & & 1,6 & 6,2 & 131 & 3,7 & 6,1 & 121 \\
\hline 24 & & 903,2 & 358 & & 1,9 & 26,2 & 65 & 3,7 & 26,6 & 50 \\
\hline 32 & & 1606,9 & 639,5 & & 1 & 28,8 & 56 & 1,2 & 22,8 & 34 \\
\hline 42 & & 2769,3 & 1104,4 & & 1,1 & 76,4 & 40 & 1,9 & 75,7 & 28 \\
\hline 55 & & & 1896,7 & 459,5 & 1,5 & 30 & 95 & 3,9 & 30 & 60 \\
\hline
\end{tabular}

\begin{tabular}{|c|c|c|c|c|c|c|c|c|c|c|c|}
\hline \multicolumn{12}{|c|}{ SEV 12} \\
\hline \multirow{2}{*}{$\begin{array}{c}A B / 2 \\
(\mathrm{~m})\end{array}$} & \multicolumn{5}{|c|}{ MN (m) } & \multirow[t]{2}{*}{$\begin{array}{c}\Delta V \\
(m V)\end{array}$} & \multirow[t]{2}{*}{$\begin{array}{c}\mathrm{I} \\
(\mathrm{mA})\end{array}$} & \multirow[t]{2}{*}{$\begin{array}{c}\rho_{\mathrm{a} 1} \\
(\Omega \mathrm{m})\end{array}$} & \multirow[t]{2}{*}{$\begin{array}{c}\Delta V \\
(m V)\end{array}$} & \multirow[t]{2}{*}{$\begin{array}{c}I \\
(\mathrm{~mA})\end{array}$} & \multirow[t]{2}{*}{$\begin{array}{c}\rho_{\mathrm{a} 2} \\
(\Omega \mathrm{m})\end{array}$} \\
\hline & 0,5 & 2 & 5 & 20 & 50 & & & & & & \\
\hline 1 & 5,89 & & & & & 70 & 5,6 & 74 & & & \\
\hline 1,3 & 10,22 & & & & & 34,4 & 4,4 & 80 & & & \\
\hline 1,8 & 19,96 & & & & & 26,2 & 5,8 & 90 & & & \\
\hline 2,4 & 35,8 & & & & & 16,2 & 7,9 & 73 & & & \\
\hline 3,2 & 63,95 & & & & & 9,1 & 9,7 & 60 & & & \\
\hline 4,2 & 110,4 & & & & & 3 & 7,6 & 44 & & & \\
\hline 5,5 & 189,7 & 45,95 & & & & 2,3 & 10,5 & 42 & 6,6 & 10,3 & 29 \\
\hline 7,5 & 353 & 86,79 & & & & 1,8 & 15,2 & 42 & 7,4 & 15 & 43 \\
\hline 10 & 627,9 & 155,5 & & & & 10,8 & 183,4 & 37 & 47,9 & 182,3 & 41 \\
\hline 13 & 1061,4 & 263,9 & & & & 5,8 & 147,8 & 42 & 24,8 & 147 & 45 \\
\hline 18 & 2035,4 & 507,4 & 199,6 & & & 5 & 264 & 39 & 22 & 263 & 42 \\
\hline 24 & 3618,7 & 903,2 & 358 & & & 1,7 & 181,8 & 34 & 7,4 & 180,3 & 37 \\
\hline 32 & & 1606,9 & 639,5 & & & 2,8 & 160,4 & 28 & 8,5 & 159,7 & 34 \\
\hline 42 & & 2769,3 & 1104,4 & & & 1,1 & 163,7 & 19 & 3,4 & 162 & 23 \\
\hline 55 & & & 1896,7 & 459,5 & & 1,8 & 349 & 10 & 9 & 350 & 12 \\
\hline 75 & & & 3530,4 & 867,9 & & 2,1 & 329 & 23 & 2,2 & 328 & 6 \\
\hline 100 & & & 6279,3 & 1555,1 & & 1,2 & 748 & 10 & 2,2 & 741 & 5 \\
\hline 130 & & & & 2638,9 & 1022,6 & 1,6 & 929 & 5 & 4,2 & 926 & 5 \\
\hline
\end{tabular}

\begin{tabular}{|c|c|c|c|c|c|c|c|c|c|c|c|}
\hline \multicolumn{12}{|c|}{ SEV 13} \\
\hline \multirow{2}{*}{$\begin{array}{c}\mathrm{AB} / 2 \\
(\mathrm{~m})\end{array}$} & \multicolumn{5}{|c|}{$\mathrm{MN}(\mathrm{m})$} & \multirow[t]{2}{*}{$\begin{array}{c}\Delta V \\
(m V)\end{array}$} & \multirow[t]{2}{*}{$\begin{array}{c}I \\
(m A)\end{array}$} & \multirow[t]{2}{*}{$\begin{array}{c}\rho_{\mathrm{a} 1} \\
(\Omega \mathrm{m})\end{array}$} & \multirow[t]{2}{*}{$\begin{array}{c}\Delta V \\
(m V)\end{array}$} & \multirow[t]{2}{*}{$\begin{array}{c}I \\
(m A)\end{array}$} & \multirow[t]{2}{*}{$\begin{array}{c}\rho_{\mathrm{a} 2} \\
(\Omega \mathrm{m})\end{array}$} \\
\hline & 0,5 & 2 & 5 & 20 & 50 & & & & & & \\
\hline 1 & 5,89 & & & & & 709 & 1,5 & 2784 & & & \\
\hline 1,3 & 10,22 & & & & & 178 & 1,2 & 1516 & & & \\
\hline 1,8 & 19,96 & & & & & 708 & 3,3 & 4282 & & & \\
\hline 2,4 & 35,8 & & & & & 356 & 3,1 & 4111 & & & \\
\hline 3,2 & 63,95 & & & & & 280 & 5,5 & 3256 & & & \\
\hline 4,2 & 110,4 & & & & & 152,5 & 5,8 & 2903 & & & \\
\hline 5,5 & 189,7 & 45,95 & & & & 62,4 & 4,7 & 2519 & 228 & 4,7 & 2229 \\
\hline 7,5 & 353 & 86,79 & & & & 21,5 & 3,8 & 1997 & 81,2 & 3,8 & 1855 \\
\hline 10 & 627,9 & 155,5 & & & & 12,6 & 5,6 & 1413 & 54,7 & 5,7 & 1492 \\
\hline 13 & 1061,4 & 263,9 & & & & 2,6 & 2,1 & 1314 & 9,7 & 2,1 & 1219 \\
\hline 18 & 2035,4 & 507,4 & & & & 1,4 & 1,7 & 1676 & 3,6 & 1,8 & 1015 \\
\hline 24 & & 903,2 & 358 & & & 4,5 & 2,6 & 1563 & 6,5 & 2,7 & 862 \\
\hline 32 & & 1606,9 & 639,5 & & & 2,2 & 4 & 884 & 4,1 & 3,9 & 672 \\
\hline 42 & & 2769,3 & 1104,4 & & & 2,5 & 10,9 & 635 & 3,8 & 11 & 382 \\
\hline 55 & & 4750,1 & 1896,7 & & & 1,3 & 15,4 & 401 & 1,7 & 15,7 & 205 \\
\hline 75 & & & 3530,4 & 867,9 & & 1,7 & 13,8 & 435 & 2,8 & 13,7 & 177 \\
\hline 100 & & & 6279,3 & 1555,1 & & 1,6 & 18,1 & 555 & 4,7 & 18 & 406 \\
\hline 130 & & & & 2638,9 & 1022,6 & 5,8 & 16,2 & 945 & 2,3 & 16,2 & 145 \\
\hline
\end{tabular}




\begin{tabular}{|c|c|c|c|c|c|c|c|c|c|c|}
\hline \multicolumn{11}{|c|}{ SEV 14} \\
\hline \multirow{2}{*}{$\begin{array}{c}A B / 2 \\
\text { (m) }\end{array}$} & \multicolumn{4}{|c|}{ MN (m) } & \multirow[t]{2}{*}{$\begin{array}{c}\Delta V \\
(\mathrm{mV})\end{array}$} & \multirow[t]{2}{*}{$\begin{array}{c}I \\
(m A)\end{array}$} & \multirow[t]{2}{*}{$\begin{array}{c}\rho_{\mathrm{a} 1} \\
(\Omega \mathrm{m})\end{array}$} & \multirow[t]{2}{*}{$\begin{array}{c}\Delta V \\
(m V)\end{array}$} & \multirow[t]{2}{*}{$\begin{array}{c}I \\
(m A)\end{array}$} & \multirow[t]{2}{*}{$\begin{array}{c}\rho_{\mathrm{a} 2} \\
(\Omega \mathrm{m})\end{array}$} \\
\hline & 0,5 & 2 & 5 & 20 & & & & & & \\
\hline 1 & 5,89 & & & & 706 & 2,2 & 1890 & & & \\
\hline 1,3 & 10,22 & & & & 708 & 2,1 & 3446 & & & \\
\hline 1,8 & 19,96 & & & & 223 & 2,1 & 2120 & & & \\
\hline 2,4 & 35,8 & & & & 95,6 & 2,5 & 1369 & & & \\
\hline 3,2 & 63,95 & & & & 55,9 & 3 & 1192 & & & \\
\hline 4,2 & 110,4 & & & & 25,2 & 2,4 & 1159 & & & \\
\hline 5,5 & 189,7 & 45,95 & & & 16,4 & 2,7 & 1152 & 67,1 & 2,7 & 1142 \\
\hline 7,5 & 353 & 86,79 & & & 9,1 & 2,7 & 1190 & 28,9 & 2,3 & 1091 \\
\hline 10 & 627,9 & 155,5 & & & 4,8 & 2,6 & 1159 & 17,1 & 2,6 & 1023 \\
\hline 13 & 1061,4 & 263,9 & & & 3,2 & 3,2 & 1061 & 10,4 & 3,2 & 858 \\
\hline 18 & 2035,4 & 507,4 & & & 1,3 & 3,2 & 827 & 3,7 & 3,1 & 606 \\
\hline 24 & & 903,2 & 358 & & 1,2 & 2,9 & 374 & 2,9 & 3 & 346 \\
\hline 32 & & 1606,9 & 639,5 & & 1,9 & 11,8 & 259 & 3,4 & 11,9 & 183 \\
\hline 42 & & 2769,3 & 1104,4 & & 1,5 & 17,5 & 237 & 1,6 & 17,2 & 103 \\
\hline 55 & & & 1896,7 & 459,5 & 2,8 & 34 & 156 & 2,9 & 34,5 & 39 \\
\hline 75 & & & 3530,4 & 867,9 & 2 & 42,5 & 166 & 1,3 & 42,4 & 27 \\
\hline
\end{tabular}

\begin{tabular}{|c|c|c|c|c|c|c|c|c|c|c|c|}
\hline \multicolumn{12}{|c|}{ SEV 15} \\
\hline \multirow{2}{*}{$\begin{array}{c}\mathrm{AB} / 2 \\
(\mathrm{~m})\end{array}$} & \multicolumn{5}{|c|}{$\mathrm{MN}(\mathrm{m})$} & \multirow[t]{2}{*}{$\begin{array}{c}\Delta V \\
(m V)\end{array}$} & \multirow[t]{2}{*}{$\begin{array}{c}I \\
(\mathrm{~mA})\end{array}$} & \multirow[t]{2}{*}{$\begin{array}{c}\rho_{\mathrm{a} 1} \\
(\Omega \mathrm{m})\end{array}$} & \multirow[t]{2}{*}{$\begin{array}{c}\Delta V \\
(m V)\end{array}$} & \multirow[t]{2}{*}{$\begin{array}{c}I \\
(m A)\end{array}$} & \multirow[t]{2}{*}{$\begin{array}{c}\rho_{\mathrm{a} 2} \\
(\Omega \mathrm{m})\end{array}$} \\
\hline & 0,5 & 2 & 5 & 20 & 50 & & & & & & \\
\hline 1, & 5,89 & & & & & 150,1 & 1,9 & 465 & & & \\
\hline 1,3 & 10,22 & & & & & 76,2 & 1,9 & 410 & & & \\
\hline 1,8 & 19,96 & & & & & 41,1 & 1,9 & 432 & & & \\
\hline 2,4 & 35,8 & & & & & 31,7 & 2,6 & 436 & & & \\
\hline 3,2 & 63,95 & & & & & 17,8 & 2,4 & 474 & & & \\
\hline 4,2 & 110,4 & & & & & 8,3 & 1,8 & 509 & & & \\
\hline 5,5 & 189,7 & 45,95 & & & & 2,9 & 1,5 & 367 & 15,7 & 1,4 & 515 \\
\hline 7,5 & 353 & 86,79 & & & & 2,5 & 1,5 & 588 & 6,6 & 1,4 & 409 \\
\hline 10 & 627,9 & 155,5 & & & & 5,3 & 10,2 & 326 & 30 & 10 & 467 \\
\hline 13 & 1061,4 & 263,9 & & & & 2,9 & 9,5 & 324 & 15,1 & 9,4 & 424 \\
\hline 18 & 2035,4 & 507,4 & & & & 2,3 & 11,8 & 397 & 12,5 & 11,8 & 538 \\
\hline 24 & 3618,7 & 903,2 & & & & 1,5 & 8,2 & 662 & 5,4 & 8,2 & 595 \\
\hline 32 & & 1606,9 & 639,5 & & & 4,4 & 10,5 & 673 & 11,8 & 10,2 & 740 \\
\hline 42 & & 2769,3 & 1104,4 & & & 1,3 & 5,7 & 632 & 3,4 & 5,5 & 683 \\
\hline 55 & & 4750,1 & 1896,7 & & & 1,9 & 13,6 & 664 & 5,1 & 13,6 & 711 \\
\hline 75 & & & 3530,4 & 867,9 & & 1,6 & 9,6 & 588 & 6,1 & 9,5 & 557 \\
\hline 100 & & & 6279,3 & 1555,1 & & 1,4 & 22,1 & 398 & 5,1 & 21,9 & 362 \\
\hline 130 & & & 10615 & 2638,9 & & 1,3 & 46,4 & 297 & 5,2 & 46,7 & 294 \\
\hline 180 & & & & 5073,7 & 1996,5 & 1,7 & 72,8 & 118 & 1,5 & 37,4 & 80 \\
\hline
\end{tabular}




\begin{tabular}{|c|c|c|c|c|c|c|c|c|c|c|c|}
\hline \multicolumn{12}{|c|}{ SEV 16} \\
\hline \multirow{2}{*}{$\begin{array}{c}\mathrm{AB} / 2 \\
(\mathrm{~m})\end{array}$} & \multicolumn{5}{|c|}{ MN (m) } & \multirow[t]{2}{*}{$\begin{array}{c}\Delta V \\
(m V)\end{array}$} & \multirow[t]{2}{*}{$\begin{array}{c}I \\
(m A)\end{array}$} & \multirow[t]{2}{*}{$\begin{array}{c}\rho_{\mathrm{a} 1} \\
(\Omega \mathrm{m})\end{array}$} & \multirow[t]{2}{*}{$\underset{(m V)}{\Delta V}$} & \multirow[t]{2}{*}{$\begin{array}{c}I \\
(\mathrm{~mA})\end{array}$} & \multirow[t]{2}{*}{$\begin{array}{c}\rho_{\mathrm{a} 2} \\
(\Omega \mathrm{m})\end{array}$} \\
\hline & 0,5 & 2 & 5 & 20 & 50 & & & & & & \\
\hline 1 & 5,89 & & & & & 712 & 4,4 & 953 & & & \\
\hline 1,3 & 10,22 & & & & & 716 & 3,7 & 1978 & & & \\
\hline 1,8 & 19,96 & & & & & 709 & 4,8 & 2948 & & & \\
\hline 2,4 & 35,8 & & & & & 387 & 2,5 & 5542 & & & \\
\hline 3,2 & 65,95 & & & & & 384 & 4,2 & 6030 & & & \\
\hline 4,2 & 110,4 & & & & & 163,9 & 3,6 & 5026 & & & \\
\hline 5,5 & 189,7 & 45,95 & & & & 113,4 & 4,9 & 4390 & 431 & 4,8 & 4126 \\
\hline 7,5 & 353 & 86,79 & & & & 72,2 & 7,3 & 3491 & 289 & 7,3 & 3436 \\
\hline 10 & 627,9 & 155,5 & & & & 37,1 & 6,6 & 3530 & 102,4 & 6,5 & 2450 \\
\hline 13 & 1061,4 & 263,9 & & & & 9,3 & 4,5 & 2194 & 32,3 & 4,5 & 1894 \\
\hline 18 & 2035,4 & 507,4 & & & & 3,2 & 3,1 & 2101 & 8,6 & 3,1 & 1408 \\
\hline 24 & 3618,7 & 903,2 & & & & 3,1 & 6,8 & 1650 & 8,7 & 6,8 & 1156 \\
\hline 32 & & 1606,9 & 639,5 & & & 3,2 & 5,6 & 918 & 9 & 5,6 & 1028 \\
\hline 42 & & 2769,3 & 1104,4 & & & 1,2 & 4,1 & 811 & 3,5 & 4,3 & 899 \\
\hline 55 & & & 1896,7 & 459,5 & & 1,8 & 4,7 & 726 & 7,1 & 4,7 & 694 \\
\hline 75 & & & 3530,4 & 867,9 & & 1,3 & 9,9 & 464 & 4,6 & 10 & 399 \\
\hline 100 & & & 6279,3 & 1555,1 & & 1,3 & 14,6 & 559 & 3,2 & 14,5 & 343 \\
\hline 130 & & & 10615 & 2638,9 & & 1,5 & 33 & 483 & 4,2 & 33 & 336 \\
\hline 180 & & & & 5073,7 & 1996,5 & 1,3 & 26,7 & 247 & 2,2 & 26,5 & 166 \\
\hline 240 & & & & 9032,1 & 3579,8 & 1,7 & 28,7 & 535 & 1,6 & 27,5 & 208 \\
\hline
\end{tabular}

\begin{tabular}{|c|c|c|c|c|c|c|c|c|c|c|}
\hline \multicolumn{11}{|c|}{ SEV 17} \\
\hline \multirow{2}{*}{$\begin{array}{c}A B / 2 \\
(m)\end{array}$} & \multicolumn{4}{|c|}{ MN (m) } & \multirow[t]{2}{*}{$\begin{array}{c}\Delta V \\
(m V)\end{array}$} & \multirow[t]{2}{*}{$\begin{array}{c}I \\
(m A)\end{array}$} & \multirow[t]{2}{*}{$\begin{array}{c}\rho_{\mathrm{a} 1} \\
(\Omega \mathrm{m})\end{array}$} & \multirow[t]{2}{*}{$\begin{array}{c}\Delta V \\
(m V)\end{array}$} & \multirow[t]{2}{*}{$\begin{array}{c}I \\
(m A)\end{array}$} & \multirow[t]{2}{*}{$\begin{array}{c}\rho_{\mathrm{a} 2} \\
(\Omega \mathrm{m})\end{array}$} \\
\hline & 0,5 & 2 & 5 & 20 & & & & & & \\
\hline 1 & 5,89 & & & & 584 & 8,6 & 400 & & & \\
\hline 1,3 & 10,22 & & & & 81,2 & 4,6 & 180 & & & \\
\hline 1,8 & 19,96 & & & & 293 & 7,8 & 750 & & & \\
\hline 2,4 & 35,8 & & & & 17,3 & 9,4 & 66 & & & \\
\hline 3,2 & 63,95 & & & & 5,9 & 5,9 & 64 & & & \\
\hline 4,2 & 110,4 & & & & 6,4 & 10,7 & 66 & & & \\
\hline 5,5 & 189,7 & 45,95 & & & 4,8 & 13 & 70 & 9,5 & 12,6 & 35 \\
\hline 7,5 & 353 & 86,79 & & & 2,7 & 12,6 & 76 & 9,7 & 12,2 & 69 \\
\hline 10 & 627,9 & 155,5 & & & 3,5 & 31,5 & 70 & 13,4 & 30,2 & 69 \\
\hline 13 & 1061,4 & 263,9 & & & 4,3 & 72,9 & 63 & 16,9 & 72,4 & 62 \\
\hline 18 & & 507,4 & 199,6 & & 3,1 & 28,2 & 56 & 8 & 27,9 & 57 \\
\hline 24 & & 903,2 & 358 & & 2,2 & 30,9 & 64 & 4,7 & 30,8 & 55 \\
\hline 32 & & 1606,9 & 639,5 & & 1,5 & 46,7 & 52 & 3,7 & 46,6 & 51 \\
\hline 42 & & 2769,3 & 1104,4 & & 2 & 147,4 & 38 & 5 & 145,9 & 38 \\
\hline 55 & & & 1896,7 & 459,5 & 2,3 & 153,1 & 28 & 10,9 & 152,2 & 33 \\
\hline 75 & & & 3530,4 & 867,9 & 2,2 & 3,9 & 1992 & 9,7 & 3,9 & 2159 \\
\hline 100 & & & 6279,3 & 1555,1 & 1,4 & 6,7 & 1312 & 6,2 & 6,8 & 1418 \\
\hline
\end{tabular}




\begin{tabular}{|c|c|c|c|c|c|c|c|c|c|c|c|}
\hline \multicolumn{12}{|c|}{ SEV 18} \\
\hline \multirow{2}{*}{$\begin{array}{c}\mathrm{AB} / 2 \\
(\mathrm{~m})\end{array}$} & \multicolumn{5}{|c|}{ MN (m) } & \multirow[t]{2}{*}{$\begin{array}{c}\Delta V \\
(m V)\end{array}$} & \multirow[t]{2}{*}{$\begin{array}{c}I \\
(m A)\end{array}$} & \multirow[t]{2}{*}{$\begin{array}{c}\rho_{\mathrm{a} 1} \\
(\Omega \mathrm{m})\end{array}$} & \multirow[t]{2}{*}{$\underset{(m V)}{\Delta V}$} & \multirow[t]{2}{*}{$\begin{array}{c}I \\
(\mathrm{~mA})\end{array}$} & \multirow[t]{2}{*}{$\begin{array}{c}\rho_{\mathrm{a} 2} \\
(\Omega \mathrm{m})\end{array}$} \\
\hline & 0,5 & 2 & 5 & 20 & 50 & & & & & & \\
\hline 1 & 5,89 & & & & & 709 & 1,9 & 2198 & & & \\
\hline 1,3 & 10,22 & & & & & 505 & 1,9 & 2716 & & & \\
\hline 1,8 & 19,96 & & & & & 135,9 & 1,5 & 1808 & & & \\
\hline 2,4 & 35,8 & & & & & 71,5 & 1,5 & 1706 & & & \\
\hline 3,2 & 65,95 & & & & & 114,7 & 4,3 & 1759 & & & \\
\hline 4,2 & 110,4 & & & & & 53,3 & 3,9 & 1509 & & & \\
\hline 5,5 & 189,7 & 45,95 & & & & 32,6 & 4,5 & 1374 & 131,4 & 4,4 & 1372 \\
\hline 7,5 & 353 & 86,79 & & & & 13,7 & 3,8 & 1273 & 55 & 3,9 & 1224 \\
\hline 10 & 627,9 & 155,5 & & & & 8,4 & 4,4 & 1199 & 31,7 & 4,5 & 1095 \\
\hline 13 & 1061,4 & 263,9 & & & & 3,2 & 3 & 1132 & 12,2 & 3,2 & 1006 \\
\hline 18 & 2035,4 & 507,4 & & & & 1,6 & 3,4 & 958 & 6,5 & 3,4 & 970 \\
\hline 24 & & 903,2 & 358 & & & 3,2 & 3,4 & 850 & 8,4 & 3,3 & 911 \\
\hline 32 & & 1606,9 & 639,5 & & & 1,7 & 5,1 & 536 & 4,3 & 5,2 & 529 \\
\hline 42 & & 2769,3 & 1104,4 & & & 1,4 & 12,1 & 320 & 3,3 & 12 & 304 \\
\hline 55 & & & 1896,7 & 459,5 & & 1,6 & 20,4 & 149 & 8 & 20,3 & 181 \\
\hline 75 & & & 3530,4 & 867,9 & & 2,2 & 56,7 & 137 & 7,1 & 56,6 & 109 \\
\hline 100 & & & 6279,3 & 1555,1 & & 1,3 & 21,5 & 380 & 1,4 & 21,5 & 101 \\
\hline 130 & & & & 2638,9 & 1022,6 & 2 & 81 & 65 & 6 & 80 & 77 \\
\hline 180 & & & & 5073,7 & 1996,5 & 1 & 52,7 & 96 & 2 & 52,7 & 76 \\
\hline
\end{tabular}

\begin{tabular}{|c|c|c|c|c|c|c|c|c|c|c|c|}
\hline \multicolumn{12}{|c|}{ SEV 19} \\
\hline \multirow{2}{*}{$\begin{array}{c}A B / 2 \\
(m)\end{array}$} & \multicolumn{5}{|c|}{$M N(m)$} & \multirow[t]{2}{*}{$\begin{array}{c}\Delta V \\
(m V)\end{array}$} & \multirow[t]{2}{*}{$\begin{array}{c}I \\
(\mathrm{~mA})\end{array}$} & \multirow[t]{2}{*}{$\begin{array}{c}\rho_{\mathrm{a} 1} \\
(\Omega \mathrm{m})\end{array}$} & \multirow[t]{2}{*}{$\begin{array}{c}\Delta V \\
(m V)\end{array}$} & \multirow[t]{2}{*}{$\begin{array}{c}I \\
(\mathrm{~mA})\end{array}$} & \multirow[t]{2}{*}{$\begin{array}{c}\rho_{\mathrm{a} 2} \\
(\Omega \mathrm{m})\end{array}$} \\
\hline & 0,5 & 2 & 5 & 20 & 50 & & & & & & \\
\hline 1 & 5,89 & & & & & 713 & 1,2 & 3500 & & & \\
\hline 1,3 & 10,22 & & & & & 707 & 3 & 2409 & & & \\
\hline 1,8 & 19,96 & & & & & 707 & 3,1 & 4552 & & & \\
\hline 2,4 & 35,8 & & & & & 635 & 2,7 & 8420 & & & \\
\hline 3,2 & 65,95 & & & & & 314 & 3,1 & 6680 & & & \\
\hline 4,2 & 110,4 & & & & & 107,3 & 2,5 & 4738 & & & \\
\hline 5,5 & 189,7 & 45,95 & & & & 37,1 & 2 & 3519 & 134,6 & 1,9 & 3255 \\
\hline 7,5 & 353 & 86,79 & & & & 17,8 & 2,3 & 2732 & 60,8 & 2,2 & 2399 \\
\hline 10 & 627,9 & 155,5 & & & & 12,8 & 3,3 & 2435 & 44,3 & 3,2 & 2153 \\
\hline 13 & 1061,4 & 263,9 & & & & 11,8 & 5,2 & 2409 & 41,7 & 5,2 & 2116 \\
\hline 18 & 2035,4 & 507,4 & & & & 8,4 & 7,4 & 2310 & 28,2 & 7,5 & 1908 \\
\hline 24 & 3618,7 & 903,2 & & & & 4,1 & 6,7 & 2214 & 13,4 & 6,8 & 1780 \\
\hline 32 & & 1606,9 & 639,5 & & & 7 & 7,1 & 1584 & 17,5 & 7,1 & 1576 \\
\hline 42 & & 2769,3 & 1104,4 & & & 4,4 & 8,1 & 1504 & 9,9 & 8,1 & 1350 \\
\hline 55 & & 4750,1 & 1896,7 & & & 2,7 & 9,6 & 1336 & 5 & 9,5 & 998 \\
\hline 75 & & & 3530,4 & 867,9 & & 1,9 & 7 & 958 & 5,2 & 7 & 645 \\
\hline 100 & & & 6279,3 & 1555,1 & & 1,3 & 5,5 & 1484 & 1,3 & 5,5 & 368 \\
\hline 130 & & & & 2638,9 & 1022,6 & 2,2 & 10,6 & 548 & 2,8 & 11,7 & 245 \\
\hline 180 & & & & 5073,7 & 1996,5 & 1,4 & 27,2 & 261 & 3,3 & 27 & 244 \\
\hline 240 & & & & 9032,1 & 3579,8 & 1,4 & 19 & 666 & 3,9 & 18,8 & 743 \\
\hline
\end{tabular}




\begin{tabular}{|c|c|c|c|c|c|c|c|c|c|c|}
\hline \multicolumn{11}{|c|}{ SEV 20} \\
\hline \multirow{2}{*}{$\begin{array}{c}A B / 2 \\
(m)\end{array}$} & \multicolumn{4}{|c|}{$\mathrm{MN}(\mathrm{m})$} & \multirow[t]{2}{*}{$\begin{array}{c}\Delta V \\
(m V)\end{array}$} & \multirow[t]{2}{*}{$\begin{array}{c}I \\
(m A)\end{array}$} & \multirow[t]{2}{*}{$\begin{array}{c}\rho_{\mathrm{a} 1} \\
(\Omega \mathrm{m})\end{array}$} & \multirow[t]{2}{*}{$\begin{array}{c}\Delta V \\
(m V)\end{array}$} & \multirow[t]{2}{*}{$\begin{array}{c}I \\
(\mathrm{~mA})\end{array}$} & \multirow[t]{2}{*}{$\begin{array}{c}\rho_{\mathrm{a} 2} \\
(\Omega \mathrm{m})\end{array}$} \\
\hline & 0,5 & 2 & 5 & 20 & & & & & & \\
\hline 1 & 5,89 & & & & 708 & 6,4 & 652 & & & \\
\hline 1,3 & 10,22 & & & & 552 & 5,9 & 956 & & & \\
\hline 1,8 & 19,96 & & & & 174,9 & 3,7 & 944 & & & \\
\hline 2,4 & 35,8 & & & & 301 & 9,4 & 1146 & & & \\
\hline 3,2 & 63,95 & & & & 211 & 10,7 & 1261 & & & \\
\hline 4,2 & 110,4 & & & & 301 & 24,4 & 1362 & & & \\
\hline 5,5 & 189,7 & 45,95 & & & 131,5 & 15,9 & 1569 & 552 & 15,8 & 1605 \\
\hline 7,5 & 353 & 86,79 & & & 80,5 & 17,7 & 1605 & 335 & 17,5 & 1661 \\
\hline 10 & 627,9 & 155,5 & & & 35,6 & 13,8 & 1620 & 149,7 & 14 & 1663 \\
\hline 13 & 1061,4 & 263,9 & & & 40,4 & 25,3 & 1695 & 167,7 & 25,3 & 1749 \\
\hline 18 & 2035,4 & 507,4 & & & 14,1 & 17,5 & 1640 & 58,5 & 17,5 & 1696 \\
\hline 24 & 3618,7 & 903,2 & & & 2,6 & 7,7 & 1222 & 10,9 & 7,7 & 1279 \\
\hline 32 & & 1606,9 & 639,5 & & 8,4 & 14,8 & 912 & 20,5 & 14,7 & 892 \\
\hline 42 & & 2769,3 & 1104,4 & & 2,4 & 10 & 665 & 5,9 & 10 & 652 \\
\hline 55 & & 4750,1 & 1896,7 & & 1,6 & 16,6 & 458 & 3,8 & 16,6 & 434 \\
\hline 75 & & & 3530,4 & 867,9 & 5 & 38,7 & 456 & 11,9 & 38,6 & 268 \\
\hline 100 & & & 6279,3 & 1555,1 & 6,9 & 79,6 & 544 & 8 & 80 & 156 \\
\hline
\end{tabular}

\begin{tabular}{|c|c|c|c|c|c|c|c|c|c|c|}
\hline \multicolumn{11}{|c|}{ SEV 21} \\
\hline \multirow{2}{*}{$\begin{array}{c}A B / 2 \\
(\mathrm{~m})\end{array}$} & \multicolumn{4}{|c|}{ MN (m) } & \multirow[t]{2}{*}{$\begin{array}{c}\Delta V \\
(m V)\end{array}$} & \multirow[t]{2}{*}{$\begin{array}{c}I \\
(m A)\end{array}$} & \multirow[t]{2}{*}{$\begin{array}{c}\rho_{\mathrm{a} 1} \\
(\Omega \mathrm{m})\end{array}$} & \multirow[t]{2}{*}{$\underset{(m V)}{\Delta V}$} & \multirow[t]{2}{*}{$\begin{array}{c}I \\
(\mathrm{~mA})\end{array}$} & \multirow[t]{2}{*}{$\begin{array}{c}\rho_{\mathrm{a} 2} \\
(\Omega \mathrm{m})\end{array}$} \\
\hline & 0,5 & 2 & 5 & 20 & & & & & & \\
\hline 1 & 5,89 & & & & 710 & 2,6 & 1608 & & & \\
\hline 1,3 & 10,22 & & & & 717 & 2,8 & 2617 & & & \\
\hline 1,8 & 19,96 & & & & 709 & 3,2 & 4422 & & & \\
\hline 2,4 & 35,8 & & & & 730 & 5,9 & 4429 & & & \\
\hline 3,2 & 63,95 & & & & 709 & 5,9 & 7685 & & & \\
\hline 4,2 & 110,4 & & & & 457 & 5,8 & 8699 & & & \\
\hline 5,5 & 189,7 & 45,95 & & & 112,6 & 4,2 & 5086 & 470 & 4,4 & 4908 \\
\hline 7,5 & 353 & 86,79 & & & 36,4 & 4,4 & 2920 & 136,6 & 4,6 & 2577 \\
\hline 10 & 627,9 & 155,5 & & & 24,3 & 8,2 & 1861 & 80,2 & 8,3 & 1503 \\
\hline 13 & 1061,4 & 263,9 & & & 12,1 & 7 & 1835 & 32,1 & 6,9 & 1228 \\
\hline 18 & 2035,4 & 507,4 & & & 7,2 & 6,2 & 2364 & 16 & 6,4 & 1269 \\
\hline 24 & 3618,7 & 903,2 & & & 6 & 5,2 & 4175 & 9,3 & 5,9 & 1424 \\
\hline 32 & & 1606,9 & 639,5 & & 5,3 & 5,3 & 1607 & 9,3 & 5,5 & 1081 \\
\hline 42 & & 2769,3 & 1104,4 & & 3,5 & 5,1 & 1901 & 5,6 & 5,2 & 1189 \\
\hline 55 & & 4750,1 & 1896,7 & & 2,4 & 4,9 & 2327 & 3 & 4,9 & 1161 \\
\hline 75 & & 8834,2 & 3530,4 & & 1,9 & 6,4 & 2623 & 2,3 & 6,4 & 1269 \\
\hline 100 & & & 6279,3 & 1555,1 & 3,3 & 6,1 & 3397 & 3,2 & 6,2 & 803 \\
\hline 130 & & & 10615 & 2638,9 & 3,3 & 7,9 & 4434 & 2,2 & 8 & 726 \\
\hline 180 & & & 20354 & 5073,7 & 3,1 & 12,6 & 5008 & 2,2 & 12,6 & 886 \\
\hline
\end{tabular}


ANEXO II - Curvas de inversão das 132 SEV da ilha do Marajó (ver localização na figura 32).
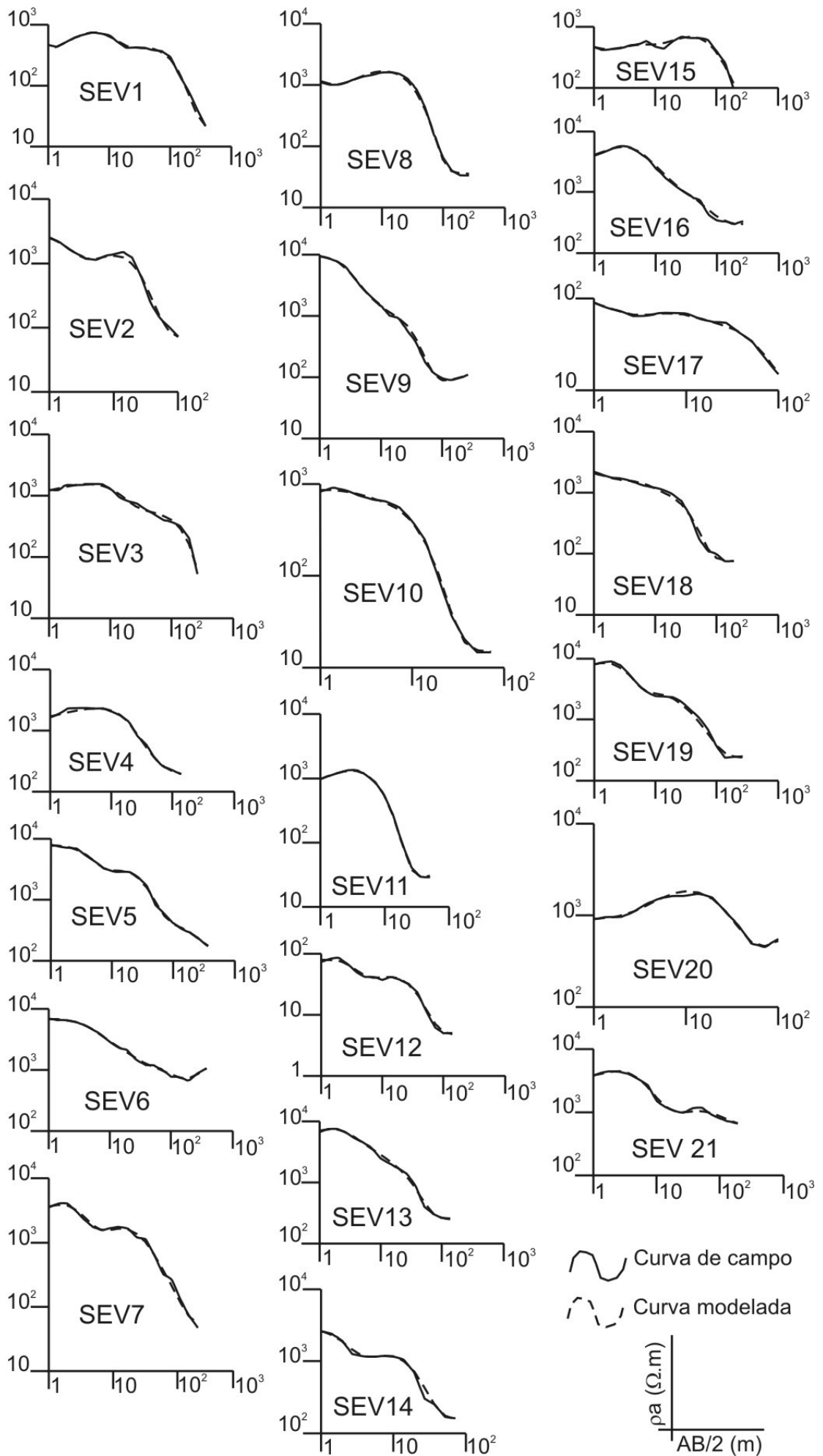
ANEXO II - Continuação.
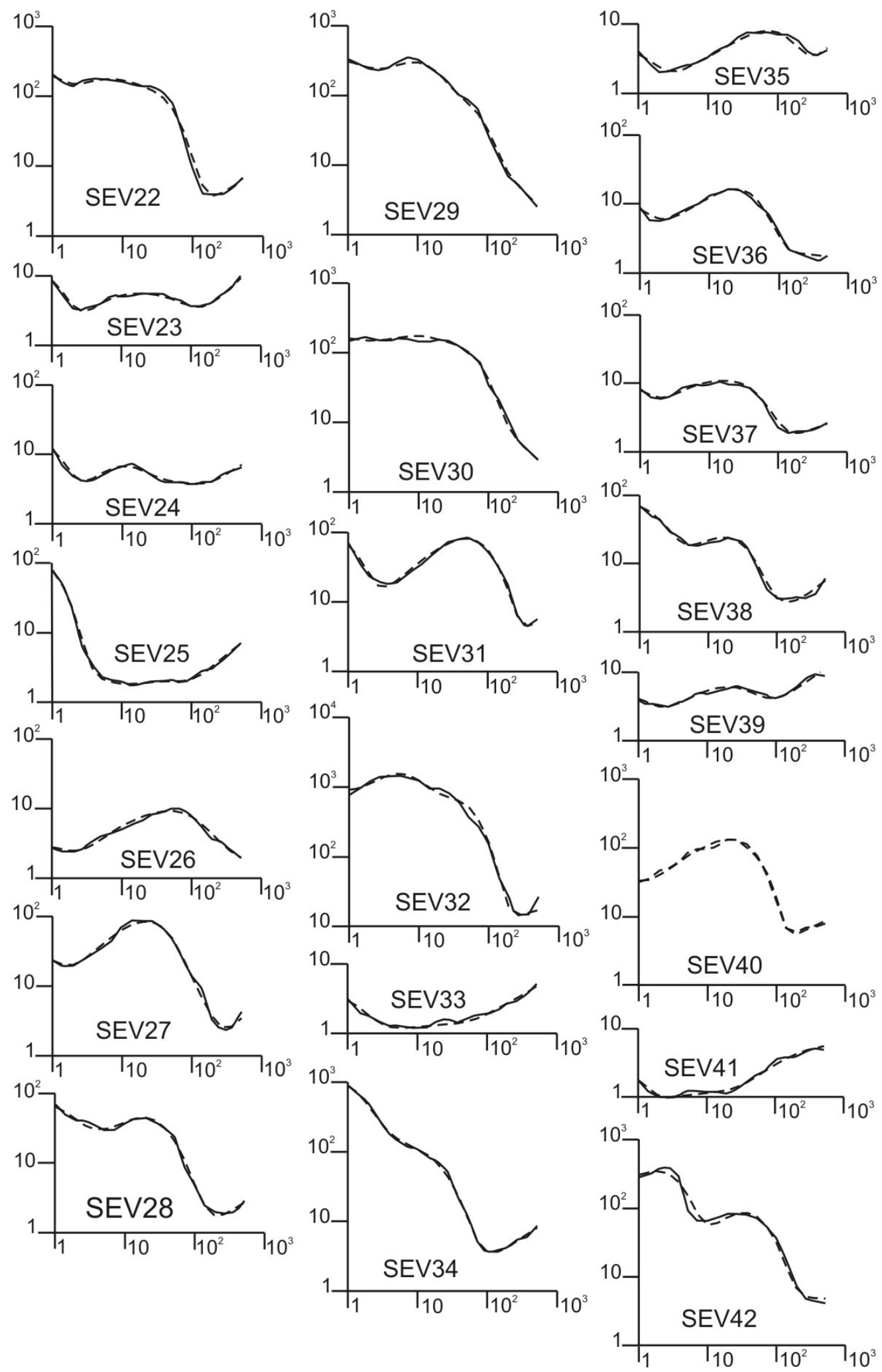
ANEXO II - Continuação.
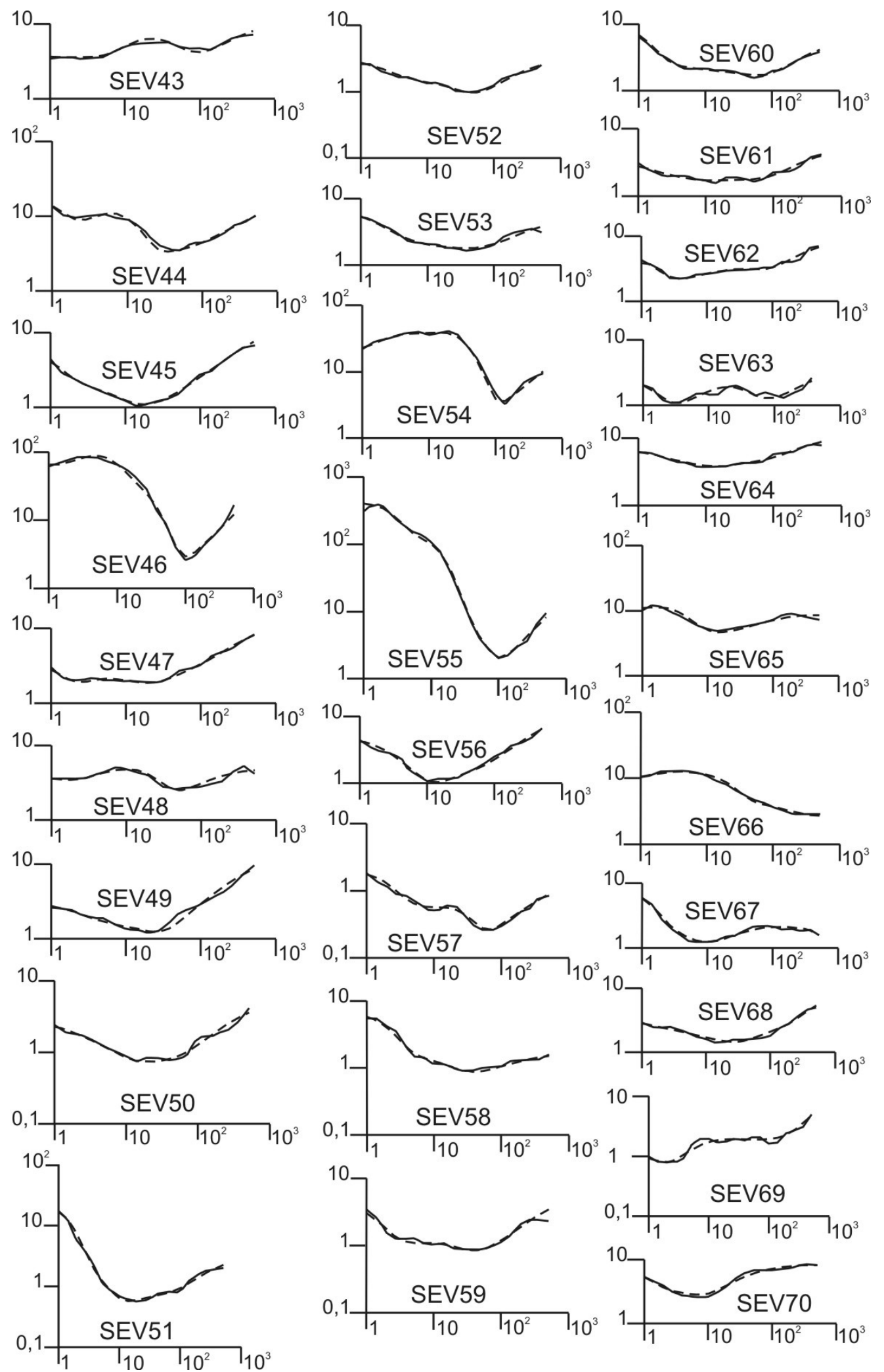
ANEXO II - Continuação.
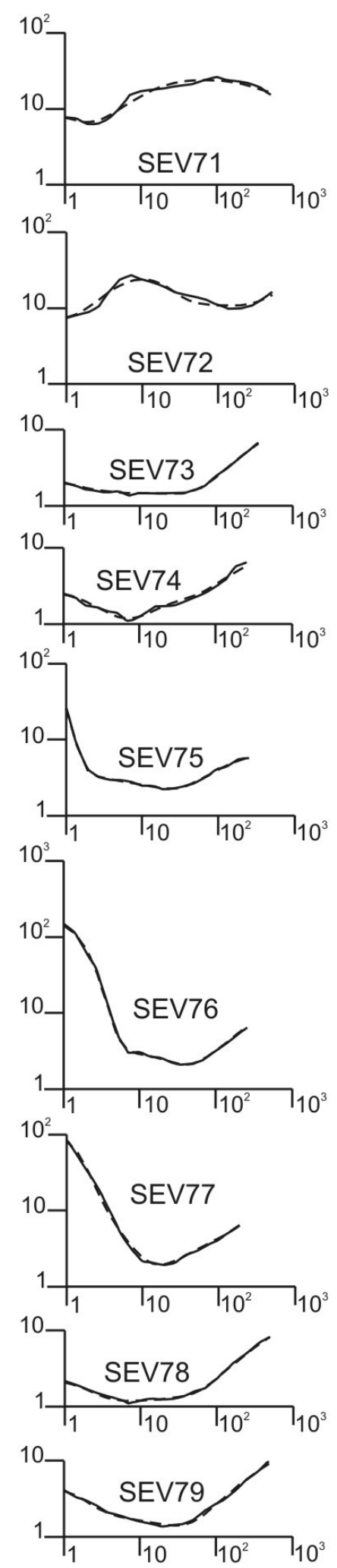
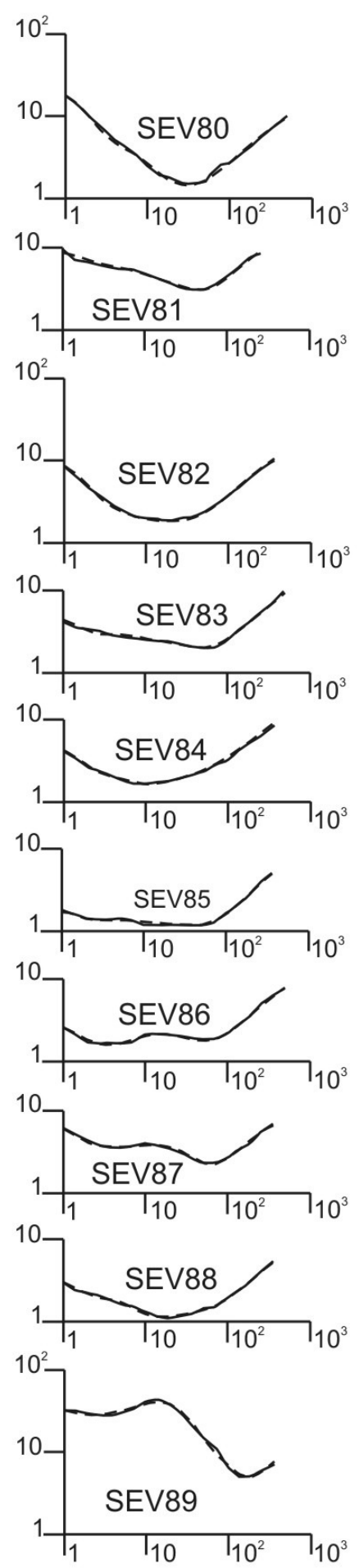
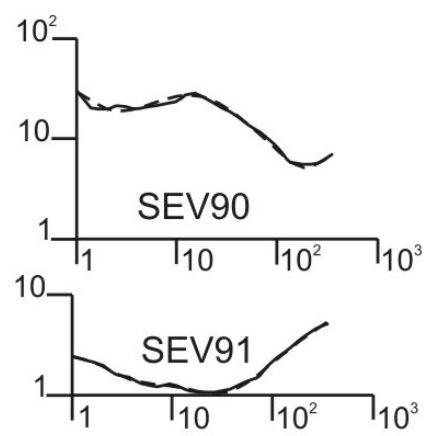

10
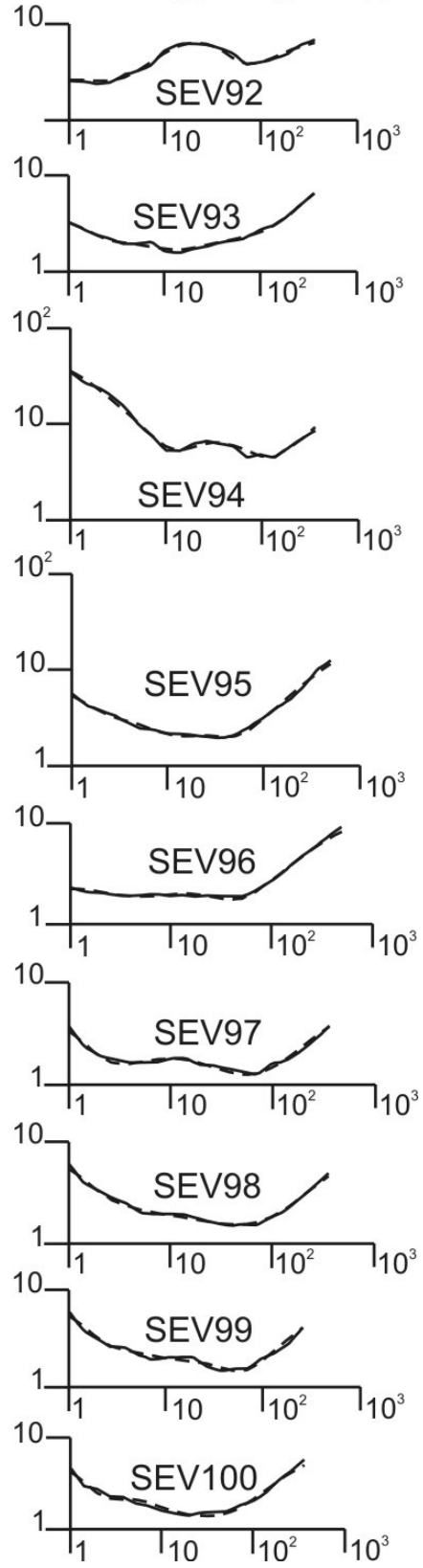
ANEXO II - Continuação.
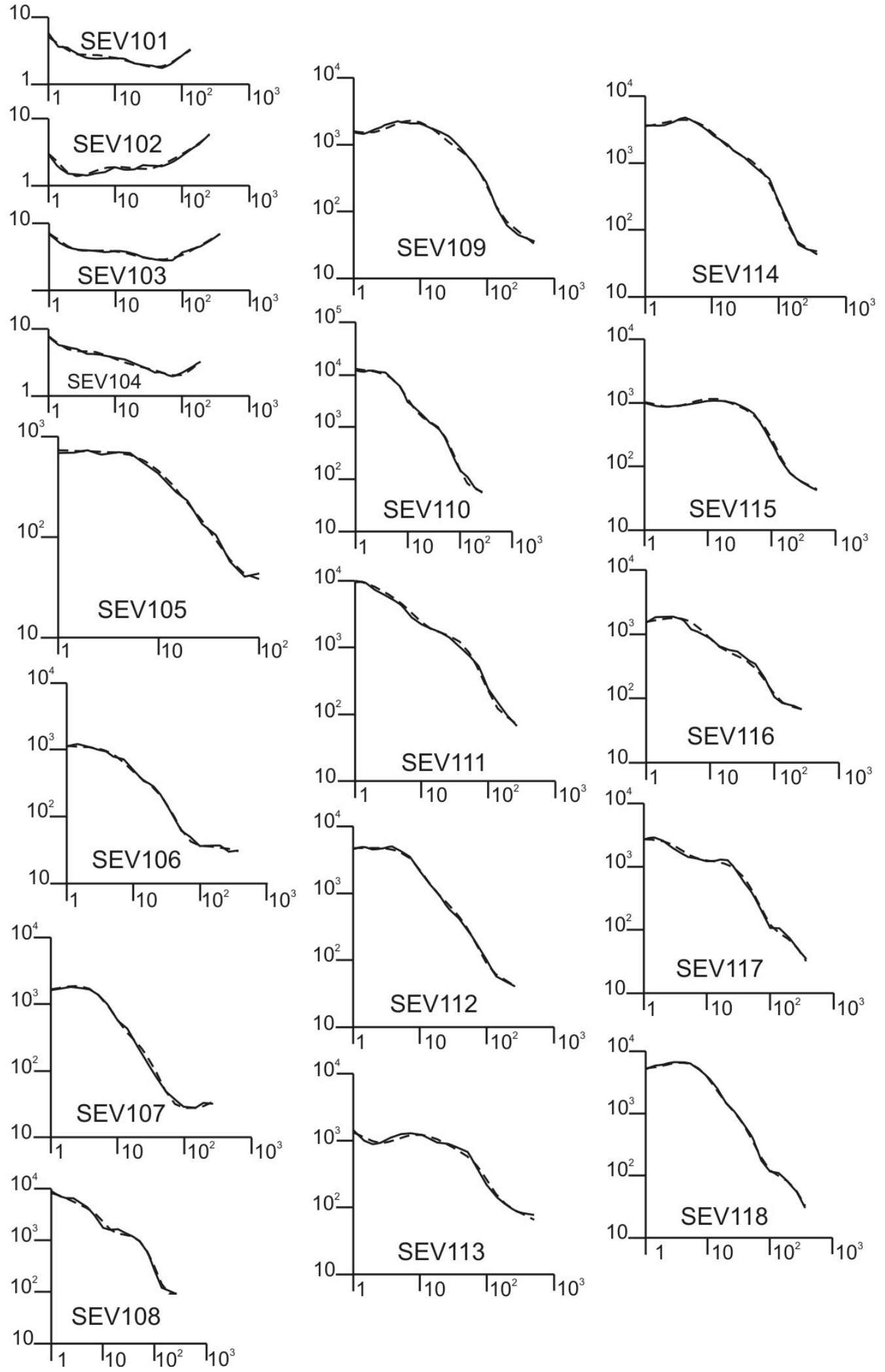
ANEXO II - Continuação.
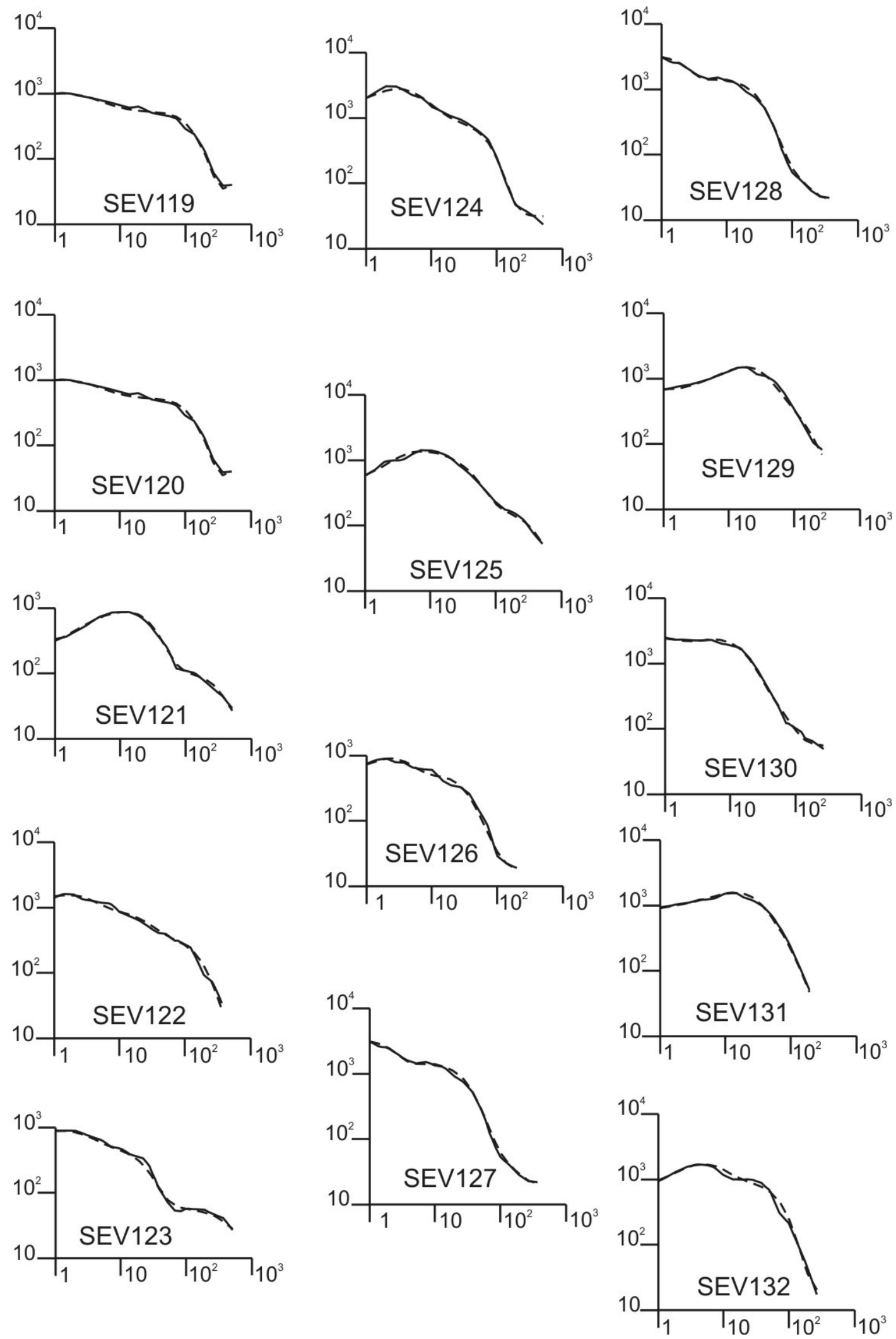
ANEXO III - Tabela dos dados de inversão das 132 SEV da ilha do Marajó (ver localização na figura 32). Note ( $\rho$ - resistividade; h espessura; $d$ - profundidade)

\begin{tabular}{|c|c|c|c|c|c|c|c|c|c|c|c|c|c|c|c|c|c|c|c|c|c|c|c|c|}
\hline \multirow{2}{*}{$\begin{array}{l}\mathbf{S} \\
\mathrm{E} \\
\mathbf{V}\end{array}$} & \multicolumn{3}{|c|}{ CAMADA 1} & \multicolumn{3}{|c|}{ CAMADA 2} & \multicolumn{3}{|c|}{ CAMADA 3} & \multicolumn{3}{|c|}{ CAMADA 4} & \multicolumn{3}{|c|}{ CAMADA 5} & \multicolumn{3}{|c|}{ CAMADA 6} & \multicolumn{3}{|c|}{ CAMADA 7} & \multicolumn{3}{|c|}{ CAMADA 8} \\
\hline & $\begin{array}{c}\rho_{1} \\
(\Omega \mathrm{m})\end{array}$ & $\begin{array}{l}\mathrm{h}_{1} \\
(\mathrm{~m})\end{array}$ & $\begin{array}{l}d_{1} \\
(m)\end{array}$ & $\begin{array}{c}\rho_{2} \\
(\Omega \mathrm{m})\end{array}$ & $\begin{array}{l}\mathrm{h}_{2} \\
(\mathrm{~m})\end{array}$ & $\begin{array}{c}\mathrm{d}_{2} \\
(\mathrm{~m})\end{array}$ & $\begin{array}{c}\rho_{3} \\
(\Omega \mathrm{m})\end{array}$ & $\begin{array}{c}\mathrm{h}_{3} \\
(\mathrm{~m})\end{array}$ & $\begin{array}{c}d_{3} \\
(m)\end{array}$ & $\begin{array}{c}\rho_{4} \\
(\Omega \mathrm{m})\end{array}$ & $\begin{array}{c}\mathrm{h}_{4} \\
(\mathrm{~m})\end{array}$ & $\begin{array}{c}\mathrm{d}_{4} \\
(\mathrm{~m})\end{array}$ & $\begin{array}{c}\rho_{5} \\
(\Omega \mathrm{m})\end{array}$ & $\begin{array}{c}\mathrm{h}_{5} \\
(\mathrm{~m})\end{array}$ & $\begin{array}{c}d_{5} \\
(\mathrm{~m})\end{array}$ & $\begin{array}{c}\rho_{6} \\
(\Omega \mathrm{m})\end{array}$ & $\begin{array}{c}\mathrm{h}_{6} \\
(\mathrm{~m})\end{array}$ & $\begin{array}{c}d_{6} \\
(m)\end{array}$ & $\begin{array}{c}\rho_{7} \\
(\Omega \mathrm{m})\end{array}$ & $\begin{array}{l}\mathrm{h}_{7} \\
(\mathrm{~m})\end{array}$ & $\begin{array}{c}d_{7} \\
(m)\end{array}$ & $\begin{array}{c}\rho_{8} \\
(\Omega \mathrm{m})\end{array}$ & $\begin{array}{c}\mathrm{h}_{8} \\
(\mathrm{~m})\end{array}$ & $\begin{array}{c}\mathrm{d}_{8} \\
(\mathrm{~m})\end{array}$ \\
\hline 1 & 347 & 0,9 & 0,9 & 1418 & 2,7 & 3,7 & 169 & 3,2 & 6,9 & 484 & 48,4 & 55,4 & 18,7 & - & - & - & - & - & - & - & - & - & - & - \\
\hline 2 & 2845 & 0,8 & 0,8 & 819 & 2,5 & 3,4 & 3800 & 3,5 & 7 & 109 & 21,1 & 28,1 & 60,6 & - & - & - & - & - & - & - & - & - & - & - \\
\hline 3 & 1113 & 0,6 & 0,6 & 1721 & 5,4 & 6 & 530 & 79,3 & 85,4 & 0,7 & - & - & - & - & - & - & - & - & - & - & - & - & - & - \\
\hline 4 & 1559 & 0,7 & 0,7 & 2542 & 8,3 & 9 & 371 & 22,1 & 31,1 & 176 & - & - & - & - & - & - & - & - & - & - & - & - & - & - \\
\hline 5 & 7862 & 2,2 & 2,2 & 1316 & 2,4 & 4,7 & 6811 & 6,2 & 10,9 & 388 & 103 & 114 & 125 & - & - & - & - & - & - & - & - & - & - & - \\
\hline 6 & 6831 & 2,3 & 2,3 & 2609 & 7,2 & 9,6 & 1113 & 44,2 & 53,8 & 417 & 91 & 145 & 3059 & 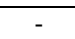 & 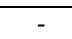 & - & - & - & - & - & - & - & - & - \\
\hline 7 & 2721 & 0,3 & 0,3 & 10112 & 0,8 & 1,1 & 1000 & 2,1 & 3,2 & 3438 & 10,1 & 13,3 & 421 & 40,3 & 53,6 & 53,6 & - & - & - & - & - & - & - & - \\
\hline 8 & 1444 & 0,5 & 0,5 & 663 & 0,8 & 1,4 & 2278 & 8,3 & 9,7 & 831 & 13,9 & 23,6 & 35,5 & - & - & - & - & - & - & - & - & - & - & - \\
\hline 9 & 10169 & 1,3 & 1,3 & 2178 & 3,3 & 4,6 & 581 & 2,1 & 6,8 & 1560 & 7,9 & 14,8 & 72,4 & 68,9 & 83,7 & 132 & - & - & - & - & - & - & - & - \\
\hline 10 & 701 & 0,3 & 0,3 & 1015 & 0,6 & 0,9 & 656 & 4,4 & 5,2 & 211 & 3,1 & 8,4 & 14,4 & - & - & - & - & - & - & - & - & - & - & - \\
\hline 11 & 770 & 0,5 & 0,5 & 1792 & 2,8 & 3,4 & 227 & 3,9 & 7,3 & 20,2 & 15 & 22,3 & 40,6 & - & - & - & - & - & - & - & - & - & - & - \\
\hline 12 & 72,9 & 0,7 & 0,7 & 379 & 0,2 & 0,9 & 22,9 & 2,1 & 3 & 64,1 & 7,3 & 10,3 & 26 & 7,4 & 17,7 & 4,6 & - & - & - & - & - & - & - & - \\
\hline 13 & 3452 & 0,6 & 0,6 & 9544 & 0,4 & 1,1 & 1523 & 0,8 & 1,9 & 2214 & 2,1 & 4,5 & 1060 & 12,4 & 16,9 & 137 & - & - & - & - & - & - & - & - \\
\hline 14 & 2903 & 1 & 1 & 617 & 1,6 & 2,6 & 2728 & 3,5 & 6,1 & 258 & 2,8 & 8,9 & 148 & - & - & - & - & - & - & - & - & - & - & - \\
\hline 15 & 526 & 0,7 & 0,7 & 173 & 0,4 & 1,1 & 966 & 1,3 & 2,3 & 366 & 5,4 & 7,7 & 1085 & 21,6 & 29,3 & 314 & 27,8 & 57,1 & 57,7 & - & - & - & - & - \\
\hline 16 & 3372 & 0,7 & 0,7 & 12057 & 1 & 1,7 & 2403 & 5,2 & 6,8 & 943 & 23,5 & 30,4 & 290 & - & - & - & - & - & - & - & - & - & - & - \\
\hline 17 & 100 & 0,8 & 0,8 & 45,2 & 1,2 & 2 & 129 & 1,4 & 3 & 52 & 27 & 30,4 & 8,6 & - & - & - & - & - & - & - & - & - & - & - \\
\hline 18 & 2335 & 0,7 & 0,7 & 1036 & 0,5 & 1,3 & 2040 & 1,8 & 3 & 943 & 14,9 & 17,9 & 73,8 & - & - & - & - & - & - & - & - & - & - & - \\
\hline 19 & 7043 & 0,6 & 0,6 & 23201 & 0,5 & 1,1 & 1404 & 1,9 & 3 & 4066 & 5,2 & 8,2 & 1220 & 22,5 & 30,7 & 232 & - & - & - & - & - & - & - & - \\
\hline 20 & 890 & 2,1 & 2,1 & 3417 & 3,1 & 5,2 & 1159 & 8 & 13 & 266 & 35 & 48,1 & 1430 & - & - & - & - & - & - & - & - & - & - & - \\
\hline 21 & 3412 & 0,8 & 0,8 & 7824 & 1,2 & 2 & 1471 & 4,6 & 6,6 & 564 & 5,6 & 12,2 & 1387 & 27,1 & 39,3 & 571 & - & - & - & - & - & & - & - \\
\hline 22 & 246 & 0,6 & 0,6 & 59 & 0,5 & 1,1 & 264 & 1,1 & 2,2 & 240 & 2 & 4,2 & 123 & 6,4 & 10,6 & 137 & 16,7 & 27,3 & 3 & 213 & 240 & 85,9 & - & - \\
\hline 23 & 2845 & 0,9 & 0,9 & 819 & 2,6 & 3,4 & 3800 & 3,6 & 7 & 109 & 21,1 & 28,1 & 60,6 & - & - & - & - & - & - & - & - & - & - & - \\
\hline 24 & 1113 & 0,6 & 0,6 & 1721 & 5,5 & 6,1 & 530 & 79,3 & 85,4 & 0,7 & - & - & - & - & 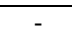 & - & - & 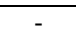 & - & - & - & - & - & - \\
\hline 25 & 1559 & 0,7 & 0,7 & 2542 & 8 & 9 & 371 & 22,1 & 31,1 & 176 & - & - & - & - & - & - & - & - & - & - & - & - & - & - \\
\hline 26 & 7862 & 2,3 & 2,3 & 1316 & 2,5 & 4,7 & 6811 & 6,2 & 10,9 & 388 & 103 & 114 & 125 & - & - & - & - & - & - & - & - & - & - & - \\
\hline 27 & 6831 & 2,3 & 2,3 & 2609 & 7,3 & 9,6 & 1113 & 44,2 & 58,3 & 417 & 91 & 145 & 3059 & - & - & - & - & - & - & - & - & - & - & - \\
\hline 28 & 2721 & 0,3 & 0,3 & 10112 & 0,8 & 1,1 & 1000 & 2,1 & 3,2 & 3438 & 10,1 & 13,3 & 421 & 40,3 & 53,6 & 53,6 & - & - & 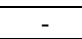 & - & - & - & - & - \\
\hline 29 & 1444 & 0,5 & 0,5 & 663 & 0,8 & 1,4 & 2278 & 8,3 & 9,7 & 831 & 13,9 & 23,6 & 35,5 & - & - & - & - & - & - & - & - & - & - & - \\
\hline 30 & 10169 & 1,3 & 1,3 & 2178 & 3,3 & 4,7 & 581 & 2,2 & 6,8 & 1560 & 7,9 & 14,8 & 72,4 & 68,9 & 83,7 & 132 & - & - & - & - & - & - & - & - \\
\hline 31 & 701 & 0,3 & 0,3 & 1015 & 0,6 & 0,9 & 656 & 4,3 & 5,3 & 211 & 3,1 & 8,4 & 14,4 & - & - & - & - & - & - & - & - & - & - & - \\
\hline 32 & 770 & 0,5 & 0,5 & 1792 & 2,8 & 3,4 & 227 & 3,9 & 7,3 & 20,2 & 15 & 22,3 & 40,6 & - & - & - & - & - & - & - & - & - & - & - \\
\hline 33 & 72,9 & 0,7 & 0,7 & 379 & 0,2 & 0,9 & 21,9 & 2,1 & 3 & 64,1 & 7,3 & 10,3 & 26 & 7,4 & 17,7 & 4,6 & - & - & - & - & - & - & - & - \\
\hline 34 & 3452 & 0,6 & 0,6 & 9544 & 0,5 & 1,1 & 1523 & 0,8 & 1,9 & 2214 & 2,6 & 4,5 & 1060 & 12,4 & 16,9 & 137 & - & - & - & - & - & - & - & - \\
\hline 35 & 4,6 & 0,7 & 0,7 & 2 & 0,1 & 0,8 & 1,3 & 1,6 & 2,4 & 4,5 & 7,5 & 9,9 & 12,8 & 48,4 & 58,3 & 1,2 & 124 & 182 & 76,3 & - & - & - & - & - \\
\hline
\end{tabular}




\begin{tabular}{|c|c|c|c|c|c|c|c|c|c|c|c|c|c|c|c|c|c|c|c|c|c|c|c|c|}
\hline 36 & 10,7 & 0,7 & 0,7 & 1,2 & 0,2 & 0,8 & 4,1 & 0,5 & 1,3 & 11,9 & 13,3 & 4,6 & 37,7 & 10,3 & 14,9 & 1,8 & 167 & 182 & 1,6 & - & - & - & - & - \\
\hline 37 & 10,1 & 0,6 & 0,6 & 0,5 & 0,1 & 0,8 & 28,8 & 0,5 & 1,3 & 10,6 & 0,6 & 1,9 & 11,9 & 22,6 & 24,4 & 1,5 & 158 & 182 & 4,1 & - & - & - & - & - \\
\hline 38 & 781,1 & 0,7 & 0,7 & 105 & 0,1 & 0,8 & 25,9 & 0,9 & 1,7 & 6,1 & 1 & 2,7 & 36 & 13,3 & 16 & 2,3 & 175 & 191 & 31,6 & - & - & - & - & - \\
\hline 39 & 5,1 & 0,7 & 0,7 & 1,3 & 0,1 & 0,8 & 2 & 0,9 & 1,7 & 6,1 & 1 & 2,7 & 7,8 & 13,3 & 16 & 3,2 & 85,2 & 101 & 24,7 & - & - & - & - & - \\
\hline 40 & 35,2 & 0,6 & 0,6 & 4,4 & 0,1 & 0,8 & 377 & 0,9 & 1,7 & 67,9 & 0,7 & 2,4 & 202 & 16,5 & 18,9 & 3,2 & 86 & 105 & 12,8 & - & - & - & - & - \\
\hline 41 & 2,4 & 0,7 & 0,7 & 0,1 & 0,1 & 0,8 & 3,1 & 0,7 & 1,5 & 0,2 & 0,2 & 1,8 & 1,2 & 21,5 & 23,3 & 6,6 & 25,5 & 48,8 & 6,3 & - & - & - & - & - \\
\hline 42 & 253 & 0,6 & 0,6 & 1263 & 0,1 & 0,8 & 1207 & 0,1 & 0,8 & 1326 & 0,3 & 1,2 & 2,4 & 0,4 & 1,5 & 244 & 13,5 & 15,1 & 4,7 & - & - & - & - & - \\
\hline 43 & 3,7 & 0,6 & 0,6 & 3,2 & 0,6 & 1,2 & 5,5 & 0,7 & 1,9 & 1,5 & 1,2 & 3,1 & 13,3 & 8 & 11,1 & 3,2 & 72,7 & 83,8 & 10,9 & - & - & - & - & - \\
\hline 44 & 18,2 & 0,6 & 0,6 & 3,2 & 0,5 & 1,1 & 8,1 & 0,6 & 1,7 & 50,6 & 1,3 & 3 & 1 & 4,3 & 7,3 & 4,1 & 76,6 & 83,8 & 14,9 & - & - & - & - & - \\
\hline 45 & 5,3 & 0,6 & 0,6 & 1,3 & 0,5 & 1,1 & 1,9 & 0,6 & 1,7 & 2,2 & 1,3 & 3 & 1 & 20,6 & 23,6 & 4,1 & 69,6 & 93,2 & 14,9 & - & - & - & - & - \\
\hline 46 & 67,1 & 0,6 & 0,6 & 40,5 & 0,4 & 1,1 & 154 & 0,6 & 1,7 & 210 & 1,3 & 3 & 29,8 & 17,5 & 20,5 & 1,5 & 62,4 & 82,9 & 316 & - & - & - & - & - \\
\hline 47 & 3,6 & 0,6 & 0,6 & 0,6 & 0,4 & 1,1 & 3,7 & 0,6 & 1,7 & 3,2 & 1,3 & 3 & 1,6 & 16,6 & 19,5 & 3,6 & 63,3 & 82,9 & 12,5 & - & - & - & - & - \\
\hline 48 & 4 & 0,6 & 0,6 & 2,2 & 0,4 & 1 & 3,7 & 0,7 & 1,7 & 5,8 & 10,4 & 12,1 & 0,9 & 12,9 & 5 & 25 & - & - & - & - & - & - & - & - \\
\hline 49 & 3 & 0,6 & 0,6 & 2,4 & 0,4 & 1 & 1,8 & 0,7 & 1,7 & 1,5 & 10,4 & 12,1 & 0,4 & 7,9 & 20 & 13,9 & - & - & - & - & - & - & - & - \\
\hline 50 & 2,5 & 0,6 & 0,6 & 1,8 & 0,4 & 1 & 1,3 & 2,5 & 3,5 & 0,6 & 4,4 & 7,9 & 0,7 & 42,1 & 50 & 5,6 & - & - & - & - & - & - & - & - \\
\hline 51 & 23,6 & 0,8 & 0,8 & 1,8 & 1,2 & 2 & 1,3 & 1,9 & 3,9 & 0,3 & 3,1 & 7 & 0,7 & 62,4 & 69,4 & 3,3 & - & - & - & - & - & - & - & - \\
\hline 52 & 3 & 0,8 & 0,8 & 1,8 & 1,2 & 2 & 1,3 & 3,7 & 5,6 & 1,5 & 5,1 & 10,7 & 0,8 & 44,8 & 55,6 & 3,1 & - & - & - & - & - & - & - & - \\
\hline 53 & 6,1 & 0,8 & 0,8 & 2,9 & 1,2 & 2 & 2,1 & 1,9 & 3,9 & 1,9 & 3,2 & 7 & 1,8 & 70,2 & 77,7 & 4,6 & - & - & - & - & - & - & - & - \\
\hline 54 & 19,1 & 0,8 & 0,8 & 62,5 & 1,2 & 2 & 25,9 & 1,9 & 3,9 & 48,8 & 15,4 & 19,3 & 1,8 & 64,5 & 83,8 & 31,3 & - & - & - & - & - & - & - & - \\
\hline 55 & 423 & 1,6 & 1,6 & 42,3 & 0,8 & 2,3 & 193 & 3,9 & 6,3 & 7,1 & 23,1 & 29,4 & 0,9 & 50,5 & 79,9 & 572 & - & - & - & - & - & - & - & - \\
\hline 56 & 4,5 & 1 & 1 & 2,1 & 2,3 & 3,3 & 0,7 & 5,8 & 9,1 & 1,6 & 20,3 & 29,4 & 2,2 & 42,8 & 72,2 & 11,2 & - & - & - & - & - & - & - & - \\
\hline 57 & 1,9 & 1,1 & 1,1 & 0,5 & 6,7 & 7,8 & 1 & 6,7 & 14,5 & 0,1 & 16,5 & 31 & 0,9 & 86,1 & 117 & 1,7 & - & - & - & - & - & - & - & - \\
\hline 58 & 6,3 & 1,1 & 1,1 & 1,3 & 6,7 & 7,8 & 0,8 & 6,7 & 14,5 & 0,7 & 16,5 & 31 & 1,3 & 70,2 & 101 & 1,6 & - & - & - & - & - & - & - & - \\
\hline 59 & 4,1 & 0,6 & 0,6 & 1 & 4 & 4,6 & 1,3 & 6,1 & 10,7 & 0,6 & 24 & 34,7 & 1,5 & 49,3 & 84 & 6,2 & - & - & - & - & - & - & - & - \\
\hline 60 & 9,2 & 0,6 & 0,6 & 2,2 & 4 & 4,6 & 1,9 & 6,1 & 10,7 & 1,8 & 24 & 34,7 & 0,8 & 24,6 & 59,3 & 5,6 & - & - & - & - & - & - & - & - \\
\hline 61 & 3,1 & 0,6 & 0,6 & 1,9 & 2 & 2,6 & 1,6 & 8,1 & 10,7 & 1,9 & 24 & 34,7 & 1,2 & 24,6 & 59,3 & 4,9 & - & - & - & - & - & - & - & - \\
\hline 62 & 5,2 & 0,7 & 0,7 & 1,7 & 2,3 & 3 & 3,2 & 7,7 & 10,7 & 3,4 & 24 & 34,7 & 1,6 & 24,6 & 59,3 & 8,7 & - & - & - & - & - & - & - & - \\
\hline 63 & 2,5 & 0,7 & 0,7 & 0,8 & 2,3 & 3 & 3,1 & 9,1 & 12 & 1 & 22,7 & 34,7 & 0,8 & 31,1 & 65,8 & 3,1 & - & - & - & - & - & - & - & - \\
\hline 64 & 6,7 & 0,7 & 0,7 & 4,7 & 2,3 & 3 & 3,4 & 9,2 & 12 & 4,9 & 22,7 & 34,7 & 4 & 31,1 & 65,8 & 10,1 & - & - & - & - & - & - & - & - \\
\hline 65 & 10,5 & 0,6 & 0,6 & 13,5 & 1,4 & 2,1 & 4 & 10 & 12 & 6,4 & 22,7 & 34,7 & 8,6 & 31,1 & 65,8 & 8,8 & - & - & - & - & - & - & - & - \\
\hline 66 & 9,6 & 0,6 & 0,6 & 14,8 & 1,4 & 2,1 & 11,5 & 10 & 12 & 3,1 & 13,3 & 25,4 & 4,2 & 40,4 & 65,8 & 2,7 & - & - & - & - & - & - & - & - \\
\hline 67 & 7,8 & 0,7 & 0,7 & 1,7 & 1,6 & 2,3 & 1,1 & 9,5 & 11,8 & 3,3 & 7,2 & 19 & 2,2 & 371 & 390 & 0,1 & - & - & - & - & - & - & - & - \\
\hline 68 & 3 & 0,7 & 0,7 & 2,2 & 2,4 & 3 & 1,6 & 8,8 & 11,8 & 0,9 & 8 & 19,9 & 2,4 & 115 & 135 & 14,2 & - & - & - & - & - & - & - & - \\
\hline 69 & 1,1 & 0,7 & 0,7 & 0,4 & 0,8 & 1,5 & 6,1 & 0,8 & 2,3 & 2,9 & 1,6 & 3,9 & 1,9 & 186 & 190 & 476 & - & - & - & - & - & - & - & - \\
\hline 70 & 6,7 & 0,7 & 0,7 & 2,1 & 0,8 & 1,5 & 6,1 & 0,8 & 2,3 & 1,5 & 3,1 & 5,4 & 6,3 & 7,1 & 12,5 & 8,2 & - & - & - & - & - & - & - & - \\
\hline 71 & 8,9 & 0,7 & 0,7 & 4,3 & 0,6 & 1,3 & 6,2 & 1,1 & 2,4 & 30,9 & 9,1 & 11,5 & 24,2 & 124 & 135 & 14,2 & - & - & - & - & - & - & - & - \\
\hline 72 & 7,1 & 0,7 & 0,7 & 3,3 & 0,3 & 0,9 & 171 & 0,8 & 1,7 & 81 & 0,6 & 2,4 & 10,6 & 371 & 373 & 201 & - & - & & - & - & - & - & - \\
\hline 73 & 2,1 & 0,7 & 0,7 & 1,5 & 21,1 & 21,8 & 1 & 17,7 & 39,5 & 3,2 & 21,4 & 60,9 & 18,7 & 25,6 & 86,5 & 19,9 & - & - & - & - & - & - & - & - \\
\hline 74 & 2,9 & 0,6 & 0,6 & 1,6 & 0,3 & 0,9 & 2,5 & 0,5 & 1,4 & 1 & 6,6 & 8 & 4,1 & 10,1 & 18,1 & 0,7 & 9,8 & 27,9 & 10,2 & - & - & - & - & - \\
\hline 75 & 209 & 0,3 & 0,3 & 1 & 0,1 & 0,4 & 4,1 & 0,5 & 0,9 & 2,9 & 5,5 & 6,4 & 1,9 & 22,9 & 29,3 & 7,4 & - & - & - & - & - & - & - & - \\
\hline 76 & 177 & 0,9 & 0,9 & 2,9 & 13,6 & 14,5 & 1,1 & 15,2 & 29,2 & 4,1 & 38,1 & 67,8 & 6,9 & 18,7 & 86,5 & 24,6 & - & - & - & - & - & - & - & - \\
\hline 77 & 118 & 0,7 & 0,7 & 8,5 & 2,1 & 7,8 & 2 & 4,3 & 7,1 & 1,3 & 9,3 & 16,3 & 5,1 & 109 & 125 & 135 & - & - & - & - & - & - & - & - \\
\hline 78 & 2,3 & 0,8 & 0,8 & 1,1 & 6,4 & 7,2 & 1,4 & 17,5 & 24,7 & 0,8 & 10,2 & 34,9 & 2,2 & 18,2 & 53,1 & 21 & - & - & - & - & - & - & - & - \\
\hline 79 & 4,6 & 0,8 & 0,8 & 1,8 & 6,4 & 7,2 & 1,3 & 17,5 & 24,7 & 0,8 & 10,2 & 34,9 & 3,8 & 15,4 & 50,3 & 20,4 & - & - & - & - & - & - & - & - \\
\hline 80 & 23,2 & 0,8 & 0,8 & 4,3 & 4,4 & 5,1 & 1,3 & 19,6 & 24,7 & 0,9 & 11,9 & 36,6 & 3,8 & 13,7 & 50,3 & 22,4 & - & - & - & - & - & - & - & - \\
\hline
\end{tabular}




\begin{tabular}{|c|c|c|c|c|c|c|c|c|c|c|c|c|c|c|c|c|c|c|c|c|c|c|c|c|}
\hline 81 & 9,9 & 0,7 & 0,7 & 5,8 & 4,4 & 5,1 & 3,5 & 19,6 & 24,7 & 0,9 & 11,9 & 36,6 & 3,8 & 7 & 46,6 & 31,1 & - & - & - & - & - & - & - & - \\
\hline 82 & 11,6 & 0,7 & 0,7 & 2,7 & 2 & 2,7 & 1,9 & 19,1 & 21,8 & 1 & 8,6 & 30,3 & 8,2 & 37,6 & 67,9 & 33,6 & - & - & - & - & - & - & - & - \\
\hline 83 & 5,3 & 0,8 & 0,8 & 3,1 & 0,003 & 0,8 & 1,3 & 0,5 & 1,2 & 4,4 & 1,4 & 2,7 & 2,3 & 21,4 & 24,1 & 0,9 & 18,1 & 42,2 & 6,2 & 98,2 & 140 & 52,5 & - & - \\
\hline 84 & 5,3 & 0,8 & 0,8 & 3,1 & 0,003 & 0,8 & 0,7 & 0,4 & 1,1 & 3,3 & 1,2 & 2,4 & 1,1 & 3,4 & 5,7 & 2,1 & 29,2 & 34,9 & 6,2 & 94,4 & 129 & 52,5 & - & - \\
\hline 85 & 2,2 & 0,7 & 0,7 & 0,7 & 0,3 & 1 & 1 & 0,3 & 1,2 & 1,8 & 1,4 & 2,8 & 1,2 & 21,4 & 24,1 & 0,8 & 25,5 & 49,6 & 3 & 50,4 & 100 & 52,5 & - & - \\
\hline 86 & 3,4 & 0,6 & 0,6 & 1,1 & 0,4 & 1 & 1,9 & 0,3 & 1,3 & 1,3 & 2,1 & 3,4 & 3,5 & 5,7 & 9,1 & 1,5 & 61,3 & 70,4 & 24,6 & - & - & - & - & - \\
\hline 87 & 8,4 & 0,6 & 0,6 & 1,5 & 0,4 & 1 & 9,5 & 0,3 & 1,3 & 2,9 & 2,1 & 3,4 & 4,7 & 12,1 & 15,5 & 1,3 & 41,7 & 57,2 & 18,8 & - & - & - & - & - \\
\hline 88 & 3,8 & 0,8 & 0,8 & 1,4 & 0,4 & 1 & 1 & 0,3 & 1,3 & 3,1 & 1,6 & 2,9 & 0,5 & 2,1 & 5 & 1,3 & 61,5 & 66,5 & 18,8 & - & - & - & - & - \\
\hline${ }^{2} 89$ & 37,5 & 0,8 & 0,8 & 5,5 & 0,2 & 0,9 & 139 & 0,3 & 1,2 & 20,2 & 0,8 & 2,1 & 20,2 & 1,2 & 3,3 & 188 & 1,9 & 5,2 & 66,4 & 3 & 8,2 & 6,1 & 10,2 & 18,4 \\
\hline 90 & 37,9 & 0,6 & 0,6 & 11,5 & 0,7 & 1,3 & 19,5 & 1,6 & 2,9 & 38,4 & 8,1 & 11 & 12,3 & 37,3 & 48,3 & 3,3 & 161 & 209 & 164 & - & - & - & - & - \\
\hline 91 & 2,6 & 0,6 & 0,6 & 5,3 & 0,1 & 0,8 & 1,2 & 3,6 & 4,3 & 1,8 & 1,9 & 6,2 & 0,9 & 32,2 & 38,4 & 12,2 & - & - & - & - & - & - & - & - \\
\hline 92 & 2,6 & 0,6 & 0,6 & 4,7 & 0,1 & 0,8 & 2 & 2,4 & 3,1 & 57,7 & 2,4 & 5,5 & 0,5 & 7,3 & 12,8 & 7,9 & - & - & - & - & - & - & - & - \\
\hline 93 & 3,8 & 0,7 & 0,7 & 1,4 & 1,1 & 1,8 & 2,9 & 2 & 3,8 & 0,8 & 2,7 & 6,5 & 2,3 & 102 & 108 & 43,5 & - & - & - & - & - & - & - & - \\
\hline 94 & 45,7 & 0,6 & 0,6 & 18,2 & 0,9 & 1,6 & 11,1 & 2,5 & 4,1 & 2,2 & 3,9 & 7,9 & 15,1 & 10,9 & 18,8 & 3,1 & 100 & 119 & 85,6 & - & - & - & - & - \\
\hline 95 & 6,8 & 0,6 & 0,6 & 2,4 & 1 & 1,6 & 4 & 1,8 & 3,4 & 0,6 & 1,2 & 4,6 & 2,8 & 2,5 & 17,1 & 0,9 & 20,3 & 37,4 & 33,7 & - & - & - & - & - \\
\hline 96 & 2,3 & 0,6 & 0,6 & 4,2 & 0,1 & 0,8 & 1,7 & 3,6 & 4,3 & 2,5 & 8,5 & 12,8 & 1,1 & 30,3 & 43,1 & 15,4 & - & - & - & - & - & - & - & - \\
\hline 97 & 4,7 & 0,6 & 0,6 & 1,1 & 0,2 & 0,8 & 1,2 & 1,2 & 2 & 2,1 & 7,8 & 9,9 & 1,1 & 73,1 & 83 & 11,8 & - & - & - & - & - & - & - & - \\
\hline 98 & 7,6 & 0,6 & 0,6 & 1,5 & 0,2 & 0,8 & 2,5 & 1,2 & 2 & 1,9 & 7,8 & 9,9 & 1,4 & 75 & 84,9 & 14,5 & - & - & - & - & - & - & - & - \\
\hline 99 & 7,5 & 0,6 & 0,6 & 1,5 & 0,3 & 0,9 & 2,4 & 2,8 & 3,7 & 1,7 & 8 & 11,6 & 2,9 & 8,8 & 20,4 & 0,2 & 9,3 & 29,6 & 16 & - & - & - & - & - \\
\hline 100 & 6 & 0,7 & 0,7 & 0,5 & 0,3 & 1 & 3,8 & 1,5 & 2,5 & 1,3 & 25,2 & 27,7 & 1 & 20,2 & 47,9 & 9,7 & & - & & - & - & - & - & - \\
\hline 101 & 7 & 0,6 & 0,6 & 1,6 & 0,7 & 1,3 & 4,4 & 1,1 & 2,4 & 2,4 & 8,6 & 11 & 1,4 & 33,7 & 44,7 & 5,8 & 49,7 & 94,4 & 15,5 & - & - & - & - & - \\
\hline 102 & 4,5 & 0,6 & 0,6 & 0,5 & 0,7 & 1,3 & 4,4 & 1,1 & 2,4 & 2 & 8,6 & 11 & 1 & 10,1 & 21,1 & 3,5 & 63,8 & 84,9 & 15,4 & - & - & - & - & - \\
\hline 103 & 9,4 & 0,7 & 0,7 & 1,5 & 0,3 & 1 & 4,4 & 2,6 & 3,5 & 3,9 & 7,5 & 11 & 2,1 & 10,1 & 21,1 & 3 & 71 & 92,1 & 13,7 & - & - & - & - & - \\
\hline 104 & 11,2 & 0,6 & 0,6 & 1,3 & 0,3 & 0,9 & 7,2 & 1,7 & 2,6 & 2,8 & 28,1 & 30,7 & 0,9 & 35,7 & 66,4 & 18,6 & - & - & - & - & - & - & - & - \\
\hline 105 & 746 & 0,8 & 0,8 & 569 & 0,3 & 1,1 & 763 & 1,1 & 2,2 & 799 & 2,5 & 4,7 & 193 & 13,5 & 18,1 & 14,3 & 2,7 & 20,8 & 35,5 & 219 & 240 & 85,9 & - & - \\
\hline 106 & 1191 & 0,8 & 0,8 & 509 & 0,2 & 1 & 1668 & 1,3 & 2,3 & 335 & 13,8 & 16,1 & 14,3 & 4,7 & 20,8 & 35,5 & 219 & 240 & 16,9 & - & - & - & - & - \\
\hline 107 & 1538 & 0,8 & 0,8 & 3237 & 0,2 & 1 & 2949 & 1,3 & 2,3 & 335 & 12,9 & 15,2 & 14,3 & 1,5 & 16,7 & 25,4 & 199 & 215 & 368 & - & - & - & - & - \\
\hline 108 & 9326 & 0,8 & 0,8 & 3237 & 0,2 & 1 & 4751 & 3,4 & 4,4 & 774 & 6,9 & 11,4 & 2535 & 14 & 25,4 & 68,9 & 190 & 215 & 368 & - & - & - & - & - \\
\hline 109 & 1748 & 0,8 & 0,8 & 263 & 0,2 & 1 & 4807 & 3,1 & 4,1 & 774 & 14,4 & 18,5 & 2535 & 6,5 & 25,1 & 68,9 & 150 & 175 & 21,8 & - & - & - & - & - \\
\hline 110 & 13662 & 0,8 & 0,8 & 6597 & 0,2 & 1 & 13066 & 2,2 & 3,2 & 1407 & 15,3 & 18,5 & 2535 & 5,2 & 23,7 & 68,9 & 174 & 198 & 23 & - & - & - & - & - \\
\hline 111 & 10723 & 0,8 & 0,8 & 6597 & 0,2 & 1,1 & 5723 & 2,1 & 3,2 & 1611 & 15,3 & 18,5 & 2535 & 6,8 & 25,4 & 97,7 & 173 & 198 & 10,2 & - & - & - & - & - \\
\hline 112 & 4807 & 0,9 & 0,9 & 3594 & 0,2 & 1,1 & 5723 & 2,7 & 3,8 & 850 & 14,8 & 18,5 & 302 & 15,8 & 34,3 & 55,3 & 164 & 198 & 10,2 & - & - & - & - & - \\
\hline 113 & 1592 & 0,8 & 0,8 & 223 & 0,2 & 1 & 840 & 1,3 & 2,3 & 5154 & 1,2 & 3,5 & 739 & 32,8 & 36,4 & 100 & 162 & 198 & 48,6 & - & - & - & - & - \\
\hline 114 & 3471 & 0,8 & 0,8 & 2719 & 0,2 & 1 & 7138 & 1,3 & 2,3 & 5154 & 1,4 & 3,7 & 1337 & 30,6 & 34,3 & 59,3 & 164 & 198 & 26 & - & - & - & - & - \\
\hline 115 & 1163 & 0,8 & 0,8 & 418 & 0,3 & 1 & 748 & 1,6 & 2,6 & 2231 & 3 & 5,6 & 821 & 33,9 & 39,4 & 63,5 & 159 & 198 & 34,3 & - & - & - & - & - \\
\hline 116 & 1434 & 0,8 & 0,8 & 2719 & 0,2 & 1 & 2257 & 0,8 & 1,8 & 3275 & 0,8 & 2,6 & 504 & 25,9 & 28,5 & 70,5 & 247 & 275 & 34,7 & - & - & - & - & - \\
\hline 117 & 2595 & 0,8 & 0,8 & 4329 & 0,2 & 1 & 4863 & 0,2 & 1,3 & 1060 & 2,5 & 3,7 & 1292 & 16,6 & 20,3 & 90,1 & 139 & 159 & 9 & - & - & - & - & - \\
\hline 118 & 5154 & 0,8 & 0,8 & 3431 & 0,2 & 0,9 & 8698 & 0,5 & 1,4 & 10975 & 1,8 & 3,3 & 1292 & 17 & 20,3 & 105 & 139 & 159 & 6,5 & - & - & - & - & - \\
\hline 119 & 1036 & 0,8 & 0,8 & 830 & 0,2 & 0,9 & 1307 & 0,5 & 1,4 & 666 & 2,3 & 3,8 & 528 & 66 & 69,7 & 14 & 159 & 228 & 309 & - & - & - & - & - \\
\hline 120 & 1574 & 0,8 & 0,8 & 3990 & 0,2 & 0,9 & 3471 & 0,5 & 1,4 & 705 & 1,8 & 3,3 & 901 & 36,2 & 39,4 & 40,8 & 189 & 228 & 309 & - & - & - & - & - \\
\hline 121 & 269 & 0,7 & 0,7 & 351 & 0,2 & 0,9 & 1831 & 0,5 & 1,4 & 705 & 0,4 & 1,8 & 1136 & 11,1 & 12,9 & 98,8 & 168 & 181 & 10,2 & - & - & - & - & - \\
\hline 122 & 1385 & 0,7 & 0,7 & 2180 & 0,2 & 0,9 & 3054 & 0,4 & 1,3 & 705 & 0,5 & 1,8 & 821 & 11,9 & 13,7 & 305 & 83,6 & 100 & 10,2 & - & - & - & - & - \\
\hline 123 & 880 & 0,7 & 0,7 & 1918 & 0,2 & 0,9 & 628 & 0,4 & 1,3 & 705 & 0,5 & 1,8 & 459 & 10,7 & 12,5 & 55,9 & 186 & 199 & 16,3 & - & - & - & - & - \\
\hline 124 & 1649 & 0,7 & 0,7 & 8800 & 0,2 & 0,9 & 6734 & 0,2 & 1,2 & 10849 & 0,1 & 1,3 & 1727 & 3,8 & 5,1 & 811 & 36,7 & 41,8 & 30,2 & - & - & - & - & - \\
\hline 125 & 515 & 0,7 & 0,7 & 295 & 0,1 & 0,7 & 6734 & 0,3 & 1,2 & 2881 & 0,7 & 1,9 & 1150 & 9,1 & 11 & 783 & 14,7 & 25,7 & 150 & 192 & 218 & 15,2 & - & - \\
\hline
\end{tabular}




\begin{tabular}{|c|c|c|c|c|c|c|c|c|c|c|c|c|c|c|c|c|c|c|c|c|c|c|c|c|}
\hline 126 & 600 & 0,7 & 0,7 & 8800 & 0,2 & 0,9 & 94,4 & 0,4 & 1,4 & 528 & 1,3 & 2,7 & 566 & 12,2 & 14,8 & 59,9 & 26,9 & 41,8 & 16,7 & - & - & - & - & - \\
\hline 127 & 3162 & 0,7 & 0,7 & 8800 & 0,2 & 0,9 & 292 & 0,4 & 1,4 & 2009 & 3,6 & 4,9 & 1048 & 13,8 & 18,7 & 59,9 & 56,9 & 75,6 & 18,7 & - & - & - & - & - \\
\hline 128 & 593 & 0,6 & 0,6 & 336 & 0,3 & 0,9 & 213 & 0,4 & 1,4 & 967 & 2,5 & 3,8 & 372 & 3,7 & 7,5 & 7,6 & 68,2 & 75,6 & 35,9 & - & - & - & - & - \\
\hline 129 & 731 & 0,7 & 0,7 & 333 & 0,2 & 0,9 & 1177 & 0,4 & 1,4 & 967 & 2,5 & 3,8 & 2984 & 8,5 & 12,3 & 372 & 66 & 78,3 & 35,9 & - & - & - & - & - \\
\hline 130 & 2750 & 0,7 & 0,7 & 2081 & 0,2 & 0,9 & 1177 & 0,4 & 1,4 & 3162 & 2,5 & 3,8 & 2081 & 5,5 & 9,3 & 302 & 26,6 & 35,9 & 53,4 & - & - & - & - & - \\
\hline 131 & 802 & 0,7 & 0,7 & 2081 & 0,2 & 0,9 & 643 & 0,4 & 1,4 & 1468 & 2,5 & 3,8 & 2081 & 11,2 & 15 & 347 & 45,6 & 60,7 & 17,5 & - & - & - & - & - \\
\hline 132 & 793 & 0,7 & 0,7 & 1451 & 0,3 & 0,9 & 3594 & 0,6 & 1,5 & 2535 & 1,6 & 3,1 & 850 & 38,2 & 41,3 & 17,5 & & & & - & - & - & - & - \\
\hline
\end{tabular}

Obs: ${ }^{a} \rho_{9}=10,9 \Omega \mathrm{m} ; \mathrm{h}_{9}=33 \mathrm{~m} ; \mathrm{d}_{9}=51,4 \mathrm{~m} ; \rho_{10}=1,6 \Omega \mathrm{m} ; \mathrm{h}_{10}=61 \mathrm{~m} ; \mathrm{d}_{10}=112 \mathrm{~m} ; \rho_{11}=81 \Omega \mathrm{m}$. 